
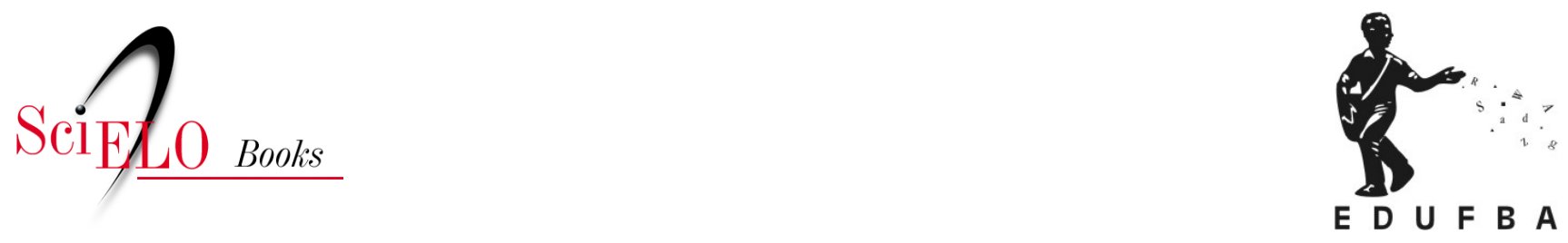

\title{
Prazer e desejo em Aristóteles
}

\author{
Juliana Ortegosa Aggio
}

AGGIO, J.O. Prazer e desejo em Aristóteles [online]. Salvador: EDUFBA, 2017, 292 p. ISBN 978-85-2322010-5. https://doi.org/10.7476/9788523220105.

All the contents of this work, except where otherwise noted, is licensed under a Creative Commons Attribution 4.0 International license.

Todo o conteúdo deste trabalho, exceto quando houver ressalva, é publicado sob a licença Creative Commons Atribição $\underline{4.0}$. 
UNIVERSIDADE FEDERAL DA BAHIA

Reitor João Carlos Salles Pires da Silva

Vice-reitor Paulo Cesar Miguez de Oliveira

Assessor do Reitor Paulo Costa Lima

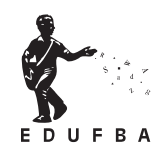

EDITORA DA UNIVERSIDADE FEDERAL DA BAHIA

Diretora Flávia Goulart Mota Garcia Rosa

\section{Conselho Editorial}

Alberto Brum Novaes

Angelo Szaniecki Perret Serpa

Caiuby Alves da Costa

Charbel Niño El Hani

Cleise Furtado Mendes

Evelina de Carvalho Sá Hoisel

José Teixeira Cavalcante Filho

Maria Vidal de Negreiros Camargo

Maria do Carmo Soares de Freitas 
2017, Autores.

Direitos para esta edição cedidos à Edufba.

Feito o Depósito Legal.

Grafia atualizada conforme o Acordo Ortográfico da

Língua Portuguesa de 1990, em vigor no Brasil desde 2009.

Capa e Projeto Gráfico Gabriel Cayres

Revisão Lia Nery

Normalização Sandra Batista

SISTEMA DE BIBLIOTECAS UFBA

Aggio, Juliana Ortegosa A226

Prazer e desejo em Aristóteles. Juliana Ortegosa Aggio. Prefácio: Marcos Zingano. Salvador, Edufba, 2017.

292 p. il. cm.

ISBN 978-85-232-1616-0

1. Aristóteles. 2. Desejo (filosofia). 3. Prazer. 4. Ética. 5. Filosofia Antiga. 6. Conduta. 7. Consciência (ética). 8. Educação Moral. I. Zingano, Marcos (pref.). II.Título.

CDU 17

Editora afiliada à
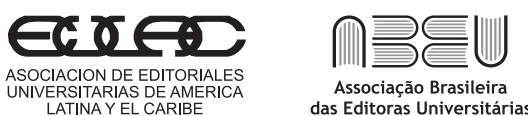

$\mathrm{CBaL}$

Editora da UFBA

Rua Barão de Jeremoabo

s/n - Campus de Ondina

40170-115 - Salvador - Bahia

Tel.: +55 71 3283-6164

Fax: +55 71 3283-6160

www.edufba.ufba.br

edufba@ufba.br 
Ao meu filho, que mora em mim, sempre. À Suany, por todo seu amor. À Sarinha e Yarinha amadas. 


\section{Sumário}

Abreviações 9

Agradecimentos II

Prefácio $\quad$ I3

$\begin{array}{ll}\text { Introdução } & 17\end{array}$

Primeira Parte: $\mathrm{O}$ prazer segundo Aristóteles

Capítulo I: Análise conceitual do prazer 33

Análise do primeiro Tratado do prazer $\quad 36$

Análise do segundo Tratado do prazer $\quad 69$

Análise comparativa dos dois Tratatos do prazer $\quad$ IO2

Capítulo II: Interpretação dos problemas $\quad$ I09

Problema I: A função do prazer $\quad$ I09

Problema II: Prazer e virtude II6

Segunda Parte: $O$ desejo segundo Aristóteles

Capítulo I: A educação do desejo I43

O problema da apreensão do fim $\quad$ I47

Objeção: o conceito de vontade $\quad$ I59 
Solução: é possível desejar corretamente $\quad$ I70

Condição de possibilidade da educação do desejo $\quad 172$

Realização da educação do desejo $\quad$ I74

$\begin{array}{ll}\text { O hábito } & \text { I82 }\end{array}$

O conhecimento em si I9O

O desejo virtuoso $\quad 193$

Querer, impulso e apetite 203

Razão e desejo: uma comunicação persuasiva 224

Capítulo II: Os desejos nas virtudes particulares 25I

A temperança e a coragem $\quad 256$

$\begin{array}{ll}\text { A generosidade } & 262\end{array}$

A magnificência $\quad 263$

A grandeza de espírito $\quad 263$

A ambição $\quad 265$

A tolerância $\quad 266$

$\begin{array}{ll}\text { A amabilidade } & 268\end{array}$

A sinceridade 270

O bom-humor 27I

$\begin{array}{ll}\text { O pudor } & 272\end{array}$

$\begin{array}{ll}\text { À guisa de conclusão } & 275\end{array}$

Referências $\quad 285$ 


\section{Abreviações}

Obras de Aristóteles:

$\begin{array}{ll}\text { AnPost. } & \text { Analíticos Posteriores } \\ \text { DA } & \text { De Anima } \\ \text { MA } & \text { De Motu Animalia } \\ \text { EE } & \text { Ética Eudêmia } \\ \text { EN } & \text { Ética Nicomaqueia } \\ \text { HA } & \text { Historia Animalium } \\ \text { Insomn. } & \text { De Insomniis } \\ \text { Mem. } & \text { De Memoria } \\ \text { MM } & \text { Magna Moralia } \\ \text { Met. } & \text { Metafísica } \\ \text { PA } & \text { De Partibus Animalium } \\ \text { PN } & \text { Parva Naturalia } \\ \text { Pol. } & \text { Política } \\ \text { Probl. } & \text { Problemata } \\ \text { Ret. } & \text { Retórica } \\ \text { Top. } & \text { Tópicos }\end{array}$




\section{Agradecimentos}

Já dizia Nelson Rodrigues em seu livro O óbvio ululante, que devemos "ler pouco e reler muito. Há uns poucos livros totais, três ou quatro, que nos salvam ou que nos perdem. É preciso relê-los, sempre e sempre, com obtusa pertinácia. E, no entanto, o leitor se desgasta, se esvai, em milhares de livros mais áridos do que três desertos". ${ }^{1}$ Tomo como minhas as palavras do dramaturgo para descrever a trajetória deste livro. Com sistemática persistência, para não dizer obsessão, li e reli as obras de Aristóteles que me impeliam insistentemente a dialogar com os seus argumentos, a reconsiderar seus pressupostos e conclusões, a verificar sua lógica que, por vezes, não parece ser tão evidente como gostaríamos. Propus-me a caminhar nos emaranhados dos conceitos expostos tão sedutoramente pelo filósofo estagirita em preferência a lançar-me três vezes no deserto de intermináveis discrepâncias da exegese aristotélica. Assim, busquei delinear o que significa prazer e desejo e, para tanto, tracei e retracei percursos, leituras, escrituras. E, se não fui, pelo menos pretendi ir ao limite de tais conceitos no âmbito moral. Para alcançar as bordas, sem, talvez, ultrapassar os limites, me direcionei até onde os desafios e as descobertas da inferência argumentativa puderam me conduzir. De certo, neste percurso que evitou a aridez do deserto, mas que não se esquivou dos maremotos devo ter armado emboscadas para o meu próprio pensamento, das quais sou unicamente responsável. Talvez não tenha chegado a Ítaca, mas em águas filosóficas mais vale navegar do que atracar

1 RODRIGUES; CASTRO, 1993, p. 43. 
em seu destino final. E se cheguei ou não em algum lugar dirá melhor o leitor. No mais, se de algo pude ser convincente é menos por mérito próprio do que pelo auxílio impecável das profundas e belas palavras de Marco Zingano, Luiz Henrique Lopes e Francis Wolff.

Agradeço a todos e todas que me acompanharam nesta jornada e às agências de fomento à pesquisa, Fundação de Amparo à Pesquisa do Estado de São Paulo (FAPESP), que financiou a pesquisa de doutorado, e à Coordenação de Aperfeiçoamento de Pessoal de Nível Superior (CAPES), que financiou o estágio de um ano na École Normale Supérieure - Paris (ENS-Paris). Por fim, também agradeço à Universidade Federal da Bahia, que possibilitou a publicação deste livro por meio do edital PRODOC/UFBA. Este livro é fruto da redação inicial de meu doutoramento, embora muito distante em alguns pontos que foram elaborados e desenvolvidos posteriormente. 


\section{Prefácio}

Juliana Aggio tem muitas virtudes, entre as quais certamente a generosidade: foi, pois, com base nesta última que me pediu para fazer um prefácio ao seu livro sobre prazer e desejo em Aristóteles. Com efeito, seu livro dispensa prefácios: é um estudo sólido, consequente, que enfrenta dificuldades cada vez maiores em busca de uma interpretação que lhe pareça mais satisfatória para o problema da ação moral em Aristóteles. Deste modo, Juliana revisita importantes passagens da ética e da psicologia moral aristotélica, propondo releituras e interpretações de textos continuamente discutidos na literatura secundária, mas também aportando novas passagens, novas alusões a trechos que ficaram, ao longo dos últimos anos, como que adormecidos, a despeito da importante renovação por que passou a filosofia aristotélica desde a metade do último século.

Com uma dissertação de mestrado sobre a teoria aristotélica da alma e uma tese de doutorado sobre a ética aristotélica, Juliana está perfeitamente capacitada para abordar temas da filosofia do Estagirita, mas também está ciente das dificuldades que rondam toda empreitada de retomada de um tema clássico e tão debatido como o prazer e desejo. O que haveria de novo a dizer, que texto já não foi escrutinado em todas as suas possibilidades de leitura? Juliana possui, porém, um trunfo em suas mãos, e dos grandes. Ela está obcecada por uma questão e é isto que a faz retirar de passagens por vezes gastas de tanta leitura o que ainda há lá de inesperado - e de muito valioso. Ter uma questão é já bastante; ter uma questão filosoficamente bem formulada é tudo. Seu problema é do último tipo e pode ser formulado assim: se o desejo é uma fonte de motivação que pode 
operar por vezes independentemente da razão, por vezes mesmo em oposição ao que comanda a razão (como no caso da acrasia, a falta de controle), o que faz com que o desejo possa mesmo assim receber o selo da razão e se conformar inteiramente aos ditames racionais? Tal como a formula, a questão é: como o desejo pode ser educado? É uma questão de filosofia: não se trata de encontrar fórmulas e práticas para educar o desejo, mas de compreender, de modo tão abstrato quanto possível, o que leva Aristóteles a supor que o desejo é educável ou, em outros termos, em que sentido estamos autorizados a supor que o desejo pode pôr-se sob o comando da razão.

Para encontrar a resposta à questão que a obsidia, Juliana divide sua investigação em duas partes. Na primeira, ela estuda a natureza do prazer; na segunda, a natureza do desejo. Em ambas as partes ela avança como se estivesse em uma guerra de trincheiras, desfazendo os obstáculos graças à clareza com que questiona os textos de Aristóteles. Para a primeira parte, ela precisa lidar com o problema bem conhecido da existência de dois tratados sobre o prazer na Ética $\mathrm{Ni}$ comaqueia, visto que não somente um não faz referência ao outro (pelo menos não explicitamente), mas sobretudo que eles propõem análises que, ao menos à primeira vista, são incompatíveis: segundo o primeiro tratado, o prazer é toda atividade não impedida; pela análise do segundo, o prazer não é uma atividade, mas aquilo que torna perfeita a realização da atividade. Ao leitor de apreciar o modo como lida com esta dificuldade; interessa-me mais ressaltar que toda a sua análise sobre a natureza do prazer é feita com vistas à defesa do que ela própria denominou de hedonismo moderado, a saber, que o prazer não pode ser o critério pelo qual julgamos que uma ação é moralmente adequada, mas tampouco pode ser expelido da análise da ação virtuosa, visto haver uma relação intrínseca entre agir virtuosamente e ter prazer. Como Juliana ressalta com a insistência de quem tem um caminho a solidamente demarcar, não é porque temos prazer que agimos bem, mas temos prazer sempre que agimos bem. Bom e mau, no sentido moral do termo, se agregam ao prazer em função da qualidade boa ou má das atividades que o prazer de algum modo vem a tornar perfeitas.

Aproximamo-nos assim de mais um dos arcanos da filosofia clássica. Embora houvesse já em sua época doutrinas morais neutras e mesmo contrárias ao prazer, Aristóteles faz parte de um importante movimento filosófico para o qual é crucial dar guarida ao prazer na ação moralmente boa - salvo que, para Aristóteles, o prazer não pode ser a razão por que agimos, tampouco um mero concomitante do fato que agimos, mas algo que, sem determinar a natureza 
moral da ação, aperfeiçoa a sua realização. O prazer ocupa um lugar que não é o mais dirimente para a ação moral, mas ocupa um lugar importante. E isto a ponto que Aristóteles se vê levado a admitir que, se o agente faz algo moralmente bom, ele então necessariamente usufrui o prazer de ter assim agido. Aristóteles ilustra sua tese com o exemplo do sujeito que passa a vida inteira treinando a duras penas como pugilista, enfrentando combates, exercícios e dores intermináveis para, enfim, obter o sucesso e ser laureado em um Jogo Olímpico. Curto, mas glorioso sucesso. Assim também o homem corajoso enfrenta, em defesa de sua cidade, a horda de invasores e, justo antes de ter a cabeça decepada por um bárbaro qualquer, vislumbra o prazer de estar fazendo o que deveria ter feito. É isto, então, o que sente o homem que abre os braços na famosa pintura de Goya dos fuzilamentos da colina do Príncipe Pio? Pode ser, mas mesmo Heitor pôs-se a correr ao ver Aquiles, na luta que conclui a Ilí$a d a$. Aristóteles aposta nesta posição do prazer que o torna intrínseco ao bem agir, mas não determinante da boa ação; Juliana segue seus passos, buscando penetrar nos arcanos de seu pensamento para entender o mistério deste prazer inevitável que acompanha toda ação moral.

O segundo eixo de seu trabalho versa sobre a natureza do desejo. Aqui também vemos Juliana lidar com uma série de textos e dificuldades com vistas a fazê-los todos militar em direção à resposta de uma questão. Uma parte importante de sua análise consiste na tentativa de mostrar que a razão deliberativa, que opera fundamentalmente sobre os meios, não esgota o domínio da razão prática. Deixo ao leitor o prazer de seguir suas análises e apreciar como avança no interior de um dédalo de problemas que atormenta qualquer intérprete de Aristóteles. Vejamos qual é a questão que dirige suas investigações e análises. O problema consiste em saber como o desejo é educável, o que é formulado por Juliana de um modo mais preciso: de que modo pode o desejo ser persuadido pela razão. Para responder à sua questão, Juliana busca em Aristóteles o que ela própria denomina, faute de mieux, de razão persuasiva, uma função da razão prática que teria alcance inclusive para os fins que nos propomos a seguir. Nos termos dela, a força da persuasão que a razão opera no desejo residiria antes em uma sedução argumentativa, algo como um acordo consentido, para a obtenção do qual os estratagemas da retórica não deixam de ter um papel relevante. É bem verdade que a simples imposição prepondera na formação do agente, quando, ainda criança, obedece às injunções dos pais, mas é na fase adulta, quando pode compreender as razões de por que 
deve fazer tal coisa, que as operações de persuasão da razão deixam de ser meras imposições externas para valer como determinações que o agente acata por si próprio, internamente. Novamente nos aproximamos dos arcanos do pensamento clássico. Ou, talvez, de seu nó górdio em Aristóteles. Para ouvir as injunções da razão, o desejo precisa ser previamente formado em direção ao justo. Para ter a direção do justo, porém, o desejo precisa ser persuadido pela razão. Mas não é isso mais uma formulação do velho problema de saber quem veio primeiro, o ovo ou a galinha? Para desfazer o nó, a noção chave é a de ethismos, habituação, que Aristóteles introduz de modo decisivo em sua ética, cuja elucidação é crucial para a correta compreensão do pensamento do Estagirita. É em direção a esta noção que vai Juliana, armada com suas questões e ansiosa pelas respostas. Ao leitor agora de seguir os passos de Juliana e apreciar o percurso que ela realiza.

Marcos Zingano

São Paulo, fevereiro de 2017. 


\title{
Introdução
}

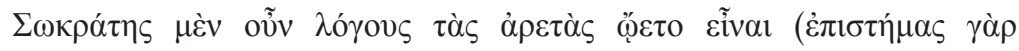

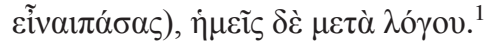

(Aristóteles, Ética Nicomaqueia, VI 13, 1144b29-30)

\begin{abstract}
I
O desejo, ninguém sabe ao certo o que é, muito menos o que fazer com ele. Mas continuamos, desde a época dos gregos ou mesmo antes, nos esforçando para apreender algo de sua natureza, algum aspecto que seja; e, mais ainda, insistimos em vislumbrar o seu papel nas ações que nos conduzem ao bem-estar moral e psicológico, portanto, à felicidade. Eis o objetivo deste livro: compreender como o desejo pode ser educado.

Em termos gerais, a questão central pode ser formulada do seguinte modo: como o desejo pode ser educado e o que isto significa para o projeto aristotélico de educação moral? Se o caráter é formado, segundo o filósofo, com a educação de nosso modo de desejar, então duas perguntas são fundamentais para iniciarmos esta investigação ora proposta. Em primeiro lugar, se o desejo não é autônomo o suficiente de modo a nos orientar para a realização do bem viver
\end{abstract}

1 "Sócrates pensou que as virtudes são operações racionais, pois todas são formas de conhecimento, mas, para nós, elas são com razão". 
(eudaimonia), mas é o princípio motor de nossas ações, certamente é necessário haver uma faculdade cognitiva capaz de educá-lo a desejar retamente. Assim, a primeira pergunta que fazemos é a seguinte: qual é esta faculdade e como ela atua no processo formativo do caráter? Em segundo lugar, se a virtude moral, excelência da parte desiderativa da alma, é responsável pela produção do fim da ação e a virtude intelectual, a phronêsis, é responsável pela apreensão do que conduz ao fim, devemos examinar como exatamente se faz a constituição do fim. Assim, a segunda pergunta que fazemos é a seguinte: como a virtude produz o fim? Há atuação de alguma faculdade cognitiva que não a deliberativa na constituição do fim ou ele é fruto apenas de uma disposição moral?

A tese que propus a defender é a seguinte: como a virtude é uma disposição adquirida por bons hábitos, o desejo é necessariamente educável. Para que o desejo seja educado, é preciso haver uma racionalidade que possa educá-lo, visto que somente a razão é capaz de apreender verdadeiramente o que é bom. Tal racionalidade, no início da formação do caráter, é externa ao agente, pois a criança a possui apenas em potência. Com o caráter já constituído, sabemos que a razão passa a estar sob o domínio do agente. Esta racionalidade prática própria ao agente moral adulto possui, ao menos, duas funções essenciais: uma responsável pela apreensão dos meios, a deliberativa, e, outra, pelo fim. Esta última, a título de distinção da função deliberativa, nós chamamos de persuasiva e o virtuoso é aquele que faz uso maximamente da racionalidade prática em ambas as funções, uma vez que ele apreende verdadeiramente tanto o bom fim e persuade o desejo a desejá-lo, como os bons meios.

Para sustentar tal tese devemos primeiramente compreender o que significa educar os desejos e por que tal educação é necessária para o projeto aristotélico da aquisição da virtude moral. Ademais, visto que não é por determinação racional ou por aquisição de conhecimento do que é correto a ser feito, mas é através da educação que é possível que o desejo venha a ser conforme a razão; dessa forma, inferimos que a educação do desejo é condição prévia necessária para que a razão possa atuar sobre ele e ser efetivamente causa coadjuvante na constituição do fim da ação. Sendo assim, pretendemos delimitar em que medida o desejo e a razão determinam o fim da ação, dialogando com as posições intelectualista e naturalista.

Em segundo lugar, visto que o prazer é o objeto natural do desejo e que educar o desejo significa, em grande medida, se habituar ter prazer com o que se deve, como e quando se deve, então devemos compreender o que é o prazer e em 
que sentido a concepção aristotélica de prazer permite que o desejo possa ser educado. Por isso, ressaltamos o fato de o filósofo ter defendido uma tese hedonista moderada, em que o prazer pode ser um bem, uma vez que esteja acompanhando uma boa atividade. Caso contrário, se o prazer fosse um mal em absoluto, jamais poderíamos ter desejo pelo que é prazerosamente bom, tampouco o prazer poderia ser considerado uma das causas da felicidade. O projeto da educação do desejo, portanto da aquisição da virtude, diante de um anti-hedonismo extremo, estaria fadado ao fracasso e já não poderíamos conceber a ética aristotélica como uma ética das virtudes.

\section{II}

Talvez pareça estranho, ou mesmo cômico, o fato de um pesquisador norte-americano, no ano de 2011, afirmar uma tese similar a de um filósofo estagirita do século IV antes de Cristo. Paul Bloom, professor e pesquisador norte-americano em psicologia e ciência cognitiva, pretende explicar por que o conhecimento e as nossas crenças interferem na forma como sentimos prazer, seja ao beber um vinho, ver uma obra de arte ou fazer sexo. Em seu livro How Pleasure Works: The new science of why we like what we like (2010), ${ }^{2}$ ele afirma que, ao sentirmos prazer, respondemos a coisas mais profundas do que gosto, cheiro ou aparência. $\mathrm{Na}$ verdade, diz, "nosso prazer é guiado pelo que sabemos, ou julgamos saber, sobre o objeto ou a pessoa com os quais interagimos". Acresce também que, atualmente, "sabemos pouco sobre o que acontece no cérebro. Mas o conhecimento direciona nossas sensações de uma forma que sejam prazerosas ou não". ${ }^{3}$

Tampouco na época de Aristóteles se conheciam as operações psicofísicas das sensações de prazer e dor. Porém, assim como o professor norte-americano atualmente postula, Aristóteles certamente acreditava que o conhecimento é determinante no modo como sentimos e desejamos. Não qualquer conhecimento, nem qualquer operação racional. Trata-se, justamente, de uma certa percepção moral ou habilidade racional que pode apreender o que é bom ou ruim dentro das circunstâncias particulares de cada situação ou contexto. No caso dos animais, como não há operação racional alguma, a orientação do que

2 Tradução: Como o prazer funciona: a nova ciência do por que nós gostamos do que nós gostamos.

3 As informações foram extraídas da entrevista concedida pelo professor Paul Bloom ao jornal Folha de São Paulo, terça-feira, 19 jul. 2011. 
é prazeroso ou doloroso encontra-se somente no âmbito da percepção. No homem, todavia, percepções e pensamentos estão envolvidos na constituição do que é prazeroso ou doloroso.

A ética aristotélica pressupõe a seguinte tese: o desejo pelo prazeroso (epithumia) e o desejo de enfrentamento da dor (thumos) devem poder se orientar pelo que julgamos ser verdadeiramente um bem; caso contrário, a educação moral não seria possível e já não poderíamos falar em termos de aquisição da virtude. Ora, adquirir virtude moral significa conseguir ter bons desejos, isto é, ter uma disposição em bem desejar. Afinal, é a disposição moral que constitui o fim da ação, objeto de nosso desejo, e é a disposição virtuosa que constitui os bons fins.

O desejo, para Aristóteles, apesar de não ser capaz de julgar o que é bom, pois que sua natureza é simplesmente buscar o prazeroso e evitar o doloroso, é capaz de seguir o que ajuíza a razão como sendo bom. É preciso, portanto, esclarecer que, segundo o filósofo, o desejo não é de uma natureza tal absolutamente avessa à racionalidade; ao contrário, ele é próprio de uma natureza que se compõe e participa da razão. E se compõe no sentido de poder ser regrada pelo que a razão determina como sendo verdadeiramente um bem. Isso significa que o desejo é educável e, mais do que isso, deve ser educado para que o homem possa realizar de modo perfeito a sua natureza. Portanto, a educação do desejo, além de ser possível conforme a estrutura da alma humana, é eticamente necessária.

Em suma, são duas as condições anímicas fundamentais para a aquisição da virtude:

1. o desejo ser naturalmente incapaz de ajuizar sobre o que é bom, mas capaz de seguir o que dita a reta razão; e

2. a razão ser naturalmente inapta para, por si só, motivar a ação, mas apta para apreender o que é bom e persuadir o desejo disso.

Seria, portanto, incongruente à sua filosofia, dizer que o desejo é um obstáculo condenável a ser transposto ou extirpado da natureza humana; ou que haverá uma batalha incessante entre desejo e razão, não havendo jamais a possibilidade de se realizar a educação do desejo; ou que o desejo deva estar submetido de modo incondicional à razão, uma vez que ela seria capaz de determinar por si só a ação e esta seria a perfeita realização do dever moral.

Sabemos que, para os estoicos, de modo geral, a afecção (pathos) é um impulso excessivo e desobediente à razão, isto é, um movimento da alma perturbador 
e contrário à natureza humana. A cólera e o desejo são agitações que pertencem à parte da alma desprovida de razão e são contrárias e hostis à razão. Como vemos em Cícero, Zenão dizia que "o pathos é um movimento da alma que obscurece a reta razão e que é contrário à natureza” (Tusc. IV 6 11). Também Diógenes de Laércio, em sua obra, Vida e opiniões dos filósofos, VII 110, afirmou que: "Segundo Zenão, a afecção é um movimento da alma irracional e contrário à natureza, ou melhor, uma inclinação exagerada”.

Pois bem, ao contrário da moral estoica, Aristóteles pressupõe uma possível e necessária harmonia das nossas afecções da parte não racional, tais como os desejos e as emoções, com a nossa racionalidade prática. Para ele, desejo e razão são inseparáveis, como o corpo e a alma, a cera e o selo impresso, o mármore e a estátua. Inseparáveis, todavia distintos. Por isso, mesmo desprovido ele próprio de razão, o desejo pode participar dela, e, por outro lado, mesmo a razão desprovida de desejo, ela pode participar dele.

O que, porém, salta aos olhos quando lemos atentamente a Ética Nicomaqueia é que o filósofo enfatiza explicitamente que a função deliberativa da razão diz respeito exclusivamente aos meios e o desejo ao fim. Aqui a espinha dorsal da ética aristotélica começa a cambalear. Se, do ponto de vista moral, o que mais interessa é a determinação dos fins, como poderíamos restringir a razão à função de deliberar sobre os meios? Seria a razão prática apenas instrumental? Estaria ela fadada a encontrar a correlação eficaz entre os meios e o fim?

Em contrapartida, se o desejo for educável, e educável em termos de habituação (ethos) e não de condicionamento mecânico (askêsis), isto é, considerando que tal educação pressupõe o julgamento correto sobre o que deve ser feito e um desejo que o siga, então devemos inferir que a razão é de algum modo capaz de determiná-lo. Isso se confirma pelo fato de o desejo, por natureza, não visar senão ao que parece ser prazeroso, mas, por educação, tornar-se capaz de ter como fim o que é verdadeiramente bom. Porém, o que não é claro na Ética $N i$ comaqueia, mas que nos incita a investigar é saber como certa operação racional pode atuar sobre o desejo, ou seja, como a razão pode participar da parte não racional, persuadindo ou educando o desejo. Com efeito, saber como a razão pode participar do desejo implica antes saber qual razão é essa ou, mais propriamente, qual função racional é essa. O problema, portanto, consiste em esclarecer este ponto obscuro: a razão deve educar o desejo a ponto de poder participar na constituição do fim da ação, mesmo que não seja através de sua função deliberativa. A necessidade de a razão ser eminentemente ativa na formação do 
caráter e na constituição do fim desejado é evidente, o que, porém, não é assim tão transparente é saber qual tipo de função racional pode atuar em conformidade ao desejo.

Evidentemente, para solucionarmos esta dificuldade devemos supor a existência de uma outra função racional, distinta da investigação deliberativa, que atue na constituição do objeto de desejo. A título de diferenciação da função deliberativa, chamemo-la de persuasiva, afinal é uma habilidade racional de apreender o que é bom de modo a persuadir o desejo a tomá-lo como seu objeto. Outra questão é a de saber como tal operação racional atua sobre o desejo.

Em princípio, todo objeto se constitui enquanto objeto de desejo na medida em que se mostra sob a forma de um bem, e tomar algo como um bem ou um mal implica, geralmente (embora não necessariamente), considerar o prazer e a dor que acompanham ou que poderão acompanhar tal objeto. Sabemos que a consideração sobre o que é prazeroso parece constituir o que é desejável na medida em que se constitui enquanto um bem aparente ou fenomênico, embora nem tudo o que pareça ser prazeroso também seja necessariamente um bem verdadeiro. Diante do que foi dito, a pergunta que surge imediatamente é a seguinte: como podemos desejar o que julgamos como sendo bom em preferência do que o que julgamos como prazeroso, uma vez que o bem e não o prazer deve ser o critério para a ação virtuosa? Em outros termos, como o desejo pode aprender a seguir o que a reta razão vê como sendo um bem?

Para responder a essa pergunta Aristóteles primeiramente determina que o prazer não pode ser o critério determinante da ação, já que ele não existe senão enquanto uma sensação que acompanha uma atividade (energeia); logo, se o prazer existe apenas como uma espécie de epifenômeno à realização da atividade, então é a atividade que deve ser o objeto do desejo e é sobre ela que deve incidir o julgamento moral. Sendo assim, não é possível julgar se é bom ou não certo prazer senão a partir do julgamento sobre a atividade acompanhada deste prazer. Ou seja, não há definição possível do valor moral do prazer senão a partir do valor atribuído à atividade. E se Aristóteles faz do julgamento que incide sobre a atividade (e não sobre o prazer) o critério avaliativo do prazer é porque tudo o que ele quer evitar é que tomemos o prazer e a dor como fundamentos do valor moral da ação. Por isso mesmo, a definição do prazer como aquilo que pertence (oikeia) a uma atividade que ele aperfeiçoa (teleioi) nos permite inferir que o julgamento moral referente à atividade é o critério avaliativo do prazer, e não o contrário, o julgamento do que é prazeroso como critério avaliativo 
da atividade. Em segundo lugar, se o prazer não é critério para a ação virtuosa, então o desejo deve aprender a se orientar não pelo que é indiscriminadamente prazeroso, mas antes pelo que determina a reta razão. Isso significa se habituar a ter prazer e dor com o que se deve, como e quando se deve, ou seja, com a atividade correta e como, quando e onde for correto realizar tal atividade.

A educação do desejo, portanto, deve ser compreendida como um processo de formação do caráter, de aquisição da virtude, o que se realiza pelo habito em desejar o que é correto, em tomar como objeto o que é bom segundo o julgamento correto. Isso porque é o julgamento correto, aquele tal qual faria o virtuoso (spoudaios), que determina o que é bom (agathos) e belo (kalos). O bom e belo, por sua vez, são também ações prazerosas em si mesmas e para aquele que os deseja em vista deles mesmos. Assim sendo, a operação desiderativa ideal é justamente aquela do homem bom, ou seja, aquela daquele que já habituou o seu desejo a ser conforme a reta razão, que aprendeu a desejar conforme o bom julgamento, que sabe encontrar a sua felicidade e prazer no que é propriamente virtuoso.

Isso significa que, ao ter adquirido a virtude, o homem virtuoso passa a desejar e a achar prazeroso o que é bom segundo o julgamento correto. Por isso, o que ele julga ser bom lhe aparece como prazeroso. Já para o vicioso, ao contrário, o que lhe aparece como prazeroso é o que ele julga ser bom.

Com efeito, se o critério para fundamentar o que é bom fosse o que aparece como prazeroso, a ética aristotélica seria absolutamente hedonista e a figura elogiável por excelência não seria a do prudente, e sim a do intemperante. O intemperante age tendo como fim apenas o que lhe dá prazer, independentemente de ser moralmente bom ou ruim. Para saber o que dá prazer, basta discriminar sensivelmente o objeto prazeroso e deliberar sobre os meios mais eficazes para obtê-lo. Não faz sentido, para o intemperante, avaliar moralmente o prazer que ele busca, por isso, ele faz um uso meramente instrumental da razão. Além do intemperante, poderíamos citar o caso do acrático (ou descontrolado) que busca o que the aparece como prazeroso, mas que é de fato prejudicial, no lugar do que ele mesmo julga ser bom.

Ao contrário do que ocorre com essas figuras do fracasso moral, para o virtuoso, o que é realmente prazeroso lhe aparece como tal. Nas palavras do filósofo: "as coisas que aparecerem a ele prazerosas são prazerosas e agradável é aquilo com o qual ele se deleita" (EN X 5: 1176a18-19), ou seja, o homem bom é o padrão (kanon) e a medida (metron) para o que é prazeroso e penoso; logo, 
o que é considerado penoso para o homem bom, mas prazeroso para alguns, assim o é por corrupções (phthorai) e por doenças (lumai); o que significa dizer que o vicioso sente prazer com o que não é realmente prazeroso, isto é, com o que sente o homem bom; todavia, não deixa de ter alguma sensação prazerosa.

Examinaremos, portanto, as razões pelas quais a educação do desejo é necessária para a aquisição da virtude, e a boa atividade, não o prazer, deve ser objeto de nosso desejo. Porém, o ponto espinhoso é que o filósofo não nos diz explicitamente como esta bela e harmônica conjunção de desejo e razão concretamente se efetiva. Esta dificuldade em saber como se realiza a educação do desejo também se apresenta ao buscarmos compreender como a prática de ações virtuosas engendra a virtude, uma vez que, antes de adquirirmos uma disposição virtuosa (hexis aretê), devemos praticar atividades similares. Ou seja, devemos, no início da formação do caráter, praticar ações justas sem sermos propriamente justos, mas a partir de uma autoridade externa, isto é, da força compulsória das leis e da conduta dos familiares e concidadãos. Ou seja, ao mesmo tempo em que a criança está sendo orientada pela autoridade exterior, ela vai gradualmente aprendendo a discriminar o certo do errado e assim vai se tornando capaz de tomar decisões por conta própria. Por um lado, a criança está sendo disciplinada e se autodisciplinando ao praticar e manter por hábito o que aprendeu. Por outro, as leis, assim como todo elogio e censura, estiveram e sempre estarão presentes para regular a disciplina dos adultos por toda a vida. No processo de aquisição das disposições virtuosas, o desejo vai sendo constituído enquanto um desejo reto. Deste modo, como veremos, as ações em conformidade à autoridade exterior precedem às ações por decisão autônoma.

Resumidamente, ser educado é passar a se habituar a desejar o que se deve. O hábito (ethos), por sua vez, é incutido por repetidas ações; no caso, boas ações. Sendo assim, em princípio, realizamos boas ações sem desejá-las por elas mesmas, mas por uma autoridade externa, isto é, em vista de ter o prazer de ser elogiado ou de evitar a dor de ser repreendido. Quanto a esse ponto, Aristóteles é claro: "a advertência e toda censura e exortação indicam que o aspecto irracional é persuadido de certo modo pela razão” (EN I 13: 1102b34-1103a1). No início da formação do caráter, portanto, o desejo não pode ser imediata e diretamente determinado pela razão. Ele deve ser preparado, cultivado, habituado a obedecê-la. É justamente em posição oposta ao naturalismo e ao intelectualismo que podemos compreender o desejo segundo Aristóteles, a saber: ele não é nem dado por uma natureza inata boa ou má, nem por uma razão autônoma o 
suficiente para determiná-lo segundo o conhecimento do bem e do mal. Desse modo, não podemos dizer que desde o início sabemos desejar retamente, mas que esta retitude é fruto de uma prática regular de boas ações que engendra esta disposição de bem desejar.

Explico-me. Se para que o desejo seja conforme a razão, ele deve ser educado a ouvi-la e a obedecê-la, disto decorre que o desejo não nasce reto e que o fim não é naturalmente um bom fim, mas que, ao contrário, deve ser constituído dessa forma. Se fosse naturalmente bom, não haveria por que educar o desejo, ou seja, não haveria motivo ético nem uma estrutura anímica para tanto. Se o fim, por sua vez, fosse determinado pela razão de modo que isto fosse causa suficiente para desejarmos tal fim e agirmos conformemente, não haveria necessidade do hábito como prática formativa do caráter; tampouco poderíamos admitir o fenômeno da acrasia, em que o agente sabe o que é bom, mas deseja e faz exatamente o contrário.

A disciplina ética, como é sabido, não tem como finalidade apenas saber o que é a virtude, mas, sobretudo, como é possível adquiri-la, visto que ela não nos é naturalmente dada. Segundo Aristóteles, o caráter é um conjunto de disposições virtuosas ou viciosas que se constituíram a partir de bons ou maus hábitos. Saber apenas o que é a virtude, como o fez Sócrates, retira toda praticidade própria ao conhecimento no domínio ético. Aristóteles critica Sócrates ao dizer que "ele costumava investigar o que é a virtude, mas não como e de quais fontes ela surgia” (EE 1216b10-11; cf. 1216b19-22). Em Menon de Platão, quando Sócrates é interrogado sobre se e como a virtude é adquirida (70a), ele responde que é impossível saber se e como a virtude é adquirida sem antes saber o que é a virtude (71a-b). Ora, se, para Sócrates, a virtude é conhecimento, conhecer o bem é se tornar virtuoso. Evidentemente, Aristóteles critica essa doutrina socrática intelectualista com a sua concepção de hábito. Ao político cabe compreender que as disposições são constituídas pelo hábito e que são elas que põem os fins, e não a razão (logos) ou o intelecto (noûs). Por isso, não é simplesmente por determinação racional ou por aquisição de conhecimento do que é correto a ser feito, mas através da educação que é possível que o desejo venha a ser conforme a razão. Vejamos resumidamente como e por que a educação do desejo é condição prévia necessária para que a razão possa atuar sobre este, sendo efetivamente causa coadjuvante na constituição do fim da ação.

Mesmo a razão sendo naturalmente capaz de apreender o que é bom, a educação prévia dos desejos é necessária para que essa operação ocorra. Ou seja, é 
preciso se habituar a desejar o que é moralmente bom para que a razão possa estar apta a apreender o que é bom e o agente possa passar de um estado de formação do caráter para um estado em que se é propriamente virtuoso. Por isso, somente alguém que já seja virtuoso poderá apreender verdadeiramente o que é o melhor a ser feito e dar as boas razões para tanto. Alguém que esteja em processo de aquisição da virtude dependerá inteiramente dos conselhos e das leis para orientar suas ações, pois que sua racionalidade não adquiriu a autonomia prática própria do homem com o caráter virtuoso já constituído.

Em suma, é necessário haver previamente um hábito moral concernente aos desejos para que a reta razão seja efetivamente causa conjunta da ação, ou seja, para que o agente possa exercitar da melhor maneira possível tanto a apreensão e persuasão do desejo quanto ao bom fim, como a função deliberativa de determinação dos bons meios. É nesse sentido que podemos afirmar que há precedência da educação moral da disposição (hexis) ao desenvolvimento da razão. Tal precedência é fundamental para distinguirmos a ética aristotélica da platônica, uma vez que, nesta última, a razão é a causa do verdadeiro desejo e, portanto, causa necessária e suficiente da ação; enquanto que, para o Estagirita, a razão só pode ser causa da ação se estiver em acordo com o desejo, ou seja, se o desejo já estiver preparado a ouvi-la. Somente assim desejo e razão podem ser, conjuntamente, causa necessária e suficiente da ação.

Como foi dito, primeiramente nós aprendemos a desejar coisas boas, sem ainda sabermos dar as boas razões e escolhermos bem as nossas ações. A partir da análise de Ética Nicomaqueia, livro X, capítulo 9, capítulo dedicado sobretudo à educação moral, podemos inferir que a educação prévia do desejo é condição para que o sujeito compreenda o sentido moral do que deve ser feito e, somente assim, possa tomar a boa decisão (1179b21-31). Por isso, do ponto de vista da formação do caráter, a educação do desejo, responsável pela constituição da virtude moral precede e é condição necessária para a aquisição plena da virtude, isto é, da virtude completa, que inclui a intelectual, a phronêsis. Podemos afirmar que o hábito que incute a virtude moral é condição prévia necessária para o aprendizado e desenvolvimento da racionalidade prática; uma vez que a virtude moral não é naturalmente dada, nem a razão é autônoma o suficiente para tornar o homem virtuoso. Salvo aqueles "bem-nascidos" que naturalmente amam o que é belo e bom, a razão não tem qualquer eficiência prática para a grande maioria comumente arrastada pelos apetites. Vale então, para a maioria, a seguinte fórmula: como a terra que deve ser cultivada para receber a semente, 
o desejo deve ser cultivado para ouvir a razão. Em suma, é necessário que haja a educação do desejo para que a razão seja reta e tenha eficiência prática.

Em outros termos, a educação do desejo é condição para que a razão seja capaz de apreender verdadeiramente o bom fim. E verdadeiramente quer dizer não apenas ver o que deve ser feito (isso o vicioso e o descontrolado também são capazes), mas persuadir o desejo a ter como objeto o que é correto, isto é, ver verdadeiramente significa apreender como bom e prazeroso isto que deve ser feito.

Visto que é possível passar a desejar retamente, podemos concluir essa introdução dizendo que a educação nada mais é do que uma preparação necessária para a atuação da razão sobre o desejo. Isso porque, segundo o Estagirita, o intelecto, por si mesmo, não é princípio motor, portanto não é capaz de determinar imediata e diretamente o desejo. Apenas um intelecto que esteja em harmonia com o desejo é capaz de atuar sobre ele. Em outros termos, a razão só é capaz de participar do desejo se e somente se houver a educação do desejo. O modo pelo qual a razão participa do desejo se realiza, primeira e previamente, através da constituição do caráter.

É de suma importância enfatizar que o fim é visto pelo virtuoso e não escolhido deliberadamente por ele. Esta declaração é um princípio adotado por Aristóteles, que parte do pressuposto de que o virtuoso vê (horan) o que é bom a ser feito (EN III 4 1113a34) e vê corretamente (horosin orthos) (EN VI 14: 1143b14). Dizer isso nada mais é do que dizer que o desejo põe o fim que dita a reta razão em sua função persuasiva e não em sua função deliberativa, uma vez que o fim não é constituído por escolha deliberada. Colocar (tithenai) um fim, em termos gerais, significa tanto perceber o que é preciso ser feito diante das circunstâncias que se apresentam, como persuadir o desejo a desejá-lo.

Enquanto o desejo não educado se guia pelo prazeroso, o já educado é capaz de ter prazer pelo que é racionalmente apreendido como um bem. $\mathrm{O}$ virtuoso se encontra numa harmonia tal que o que a razão vê como sendo o melhor, o desejo deseja. Em suma, a educação moral parece ser condição simultânea da apreensão racional verdadeira do bem e do desejo que o toma como objeto. Com efeito, o virtuoso vê e imediatamente deseja o que deve ser feito. E assim o faz porque está previamente disposto a fazê-lo. O virtuoso não poderia ver o que deve ser feito e não desejá-lo. Este seria o caso do vicioso que, mesmo sabendo o que deve ser feito, deseja e faz o contrário. Tampouco poderia o virtuoso ver o que deve ser feito, desejar e não agir conforme o que deve ser feito. Este é o caso do descontrolado (acrático), que é conduzido antes pelo desejo contrário do que 
por aquele conforme a razão. Tampouco poderia o virtuoso ver e agir corretamente, mas não o desejar propriamente, isto é, desejar o que é bom por si e em vista de si mesmo. Este, como sabemos, é o caso do controlado (encratês), que age conforme a razão, porém sem desejar o fim virtuoso por si mesmo.

A educação moral é justamente a realização da passagem entre o agir virtuosamente sem ser virtuoso ao agir virtuosamente sendo virtuoso; da passagem do agir por autoridade exterior ao agir em vista do fim virtuoso desejado por ele mesmo; do desejo pelo prazeroso ao desejo pelo que é bom e prazeroso. O desejo educado é aquele cujo objeto particular realizável aqui e agora é um bem em vista dele mesmo, que, por sua vez, também é uma expressão do desejo pelo fim último, isto é, pela virtude e felicidade. Enfim, a aquisição de virtude é condição prévia necessária para a realização da racionalidade prática em seu grau máximo de autonomia, de modo que ela seja capaz de ver o fim correto e persuadir o desejo a buscá-lo, assim como deliberar sobre os melhores meios para realizá-lo. Por isso, podemos dizer, sem hesitação, que a finalidade da educação moral é tornar prática a função persuasiva da razão, de modo que ela possa atuar sobre o desejo e ser efetivamente causa coadjuvante na constituição do fim. A educação, como veremos, torna a razão prática correta, participativa, orientadora do desejo e este, por sua vez, torna-se mais capaz de ser conforme a razão.

A razão prática, uma vez vindo a ser reta, é capaz de discriminar corretamente as circunstâncias particulares de modo a encontrar o meio termo a ser almejado na ação. Esta retitude discriminativa, esta justeza e agudeza na apreensão do fim apenas podem ocorrer naquele que está previamente preparado em termos afetivos, isto é, que seja afetivamente capaz de ver o melhor. Ou seja, o bom uso da razão está condicionado ao bem-estar afetivo. Trata-se antes de ser afetivamente capaz de ajuizar corretamente o que é bom do que de ser racional o suficiente para dominar os afetos. Ou seja, para ver o que é bom a ser feito é preciso querer ver desse modo. É preciso ter um caráter virtuoso para ver por si próprio o melhor. Por isso, o caráter se expressa não apenas no que o sujeito faz, mas também no que ele vê que deve fazer e no que ele deseja fazer.

Por exemplo, trata-se de ser colérico o suficiente para saber reivindicar justiça ou se defender de uma ofensa; de ser temperante o suficiente, isto é, na justa medida, para desfrutar moderadamente e no momento oportuno de prazeres sadios; trata-se de desejar na justa medida a enfrentar a dor de modo a ver o que é corajoso a ser feito; trata-se de ter uma sensibilidade moral própria da disposição generosa para perceber que uma dada situação exige uma ação generosa; e 
assim por diante com relação às outras virtudes particulares e suas respectivas emoções. Podemos inferir que é preciso haver engajamento afetivo para que a ação seja propriamente virtuosa. Enfim, a razão só vê o que é certo porque estamos afetivamente propensos a ver.

Podemos resumir e concluir esta introdução do seguinte modo: a ética de Aristóteles é uma ética da ação, pois, como diz o filósofo, não basta querer (boulêsis) mudar para se mudar de fato; assim como não basta ao doente simplesmente querer se curar e não fazer nada para tanto; deve-se agir para tanto, ou seja, deve-se educar o desejo para o meio termo. A ação e a persuasão são as vias de acesso da razão ao desejo. Desse modo, educar o desejo não é senão tornar-se moralmente virtuoso. Ademais, como o desejo é naturalmente a busca indiscriminada por prazer e a recusa de qualquer dor, educar o desejo significa persuadi-lo a desejar o que se deve, o que, em grande medida, pressupõe saber ter prazer e dor com o que se deve, como e quando se deve. O desejo, uma vez educado, deseja o bem em vista dele mesmo. O desejo não educado, por sua vez, é próprio das crianças e dos animais e daqueles que vivem cegamente segundo os afetos, sem ter ideia do que é belo e verdadeiramente prazeroso, enfim, são aqueles que visam o prazer de modo insaciável e indiscriminado: os adultos viciosos, como o perverso e o intemperante, e aqueles que ainda não são propriamente virtuosos nem viciosos: os controlados e os descontrolados.

\section{III}

O livro Prazer e desejo em Aristóteles se divide em duas partes. A primeira se chama "O prazer segundo Aristóteles” e a segunda, "O desejo segundo Aristóteles”. Resumidamente examinaremos, na segunda parte, o que significa a educação do desejo, este habituar-se a desejar o que é correto. Para tanto, fez-se necessário examinar, na primeira parte da tese, o modo pelo qual o objeto de desejo pode e deve depender do bom julgamento para ser constituído e não ser simplesmente determinado a partir do que nos aparece como prazeroso.

Veremos, com a análise dos dois Tratados sobre o prazer, que tudo o que Aristóteles quer com sua concepção de prazer é garantir que o objeto de desejo seja realmente prazeroso porque é bom e não o contrário: que seja bom porque é prazeroso. Uma vez tendo examinado as questões referentes ao prazer na primeira parte da tese, temos garantida a possibilidade de o desejo ser educado, visto que o objeto de desejo não deve ser simplesmente o que parece ser 
prazeroso a despeito do que a razão apreende como sendo bom. Ao contrário, ele pode e deve ser educado de modo a tomar o que é verdadeiramente bom como seu objeto, a despeito disso parecer ser prazeroso.

Como, porém, essa educação ocorre é o que veremos na segunda parte da tese. Trataremos da relação entre desejo e razão na formação do caráter virtuoso, o que implica compreender de que modo a estrutura da alma humana e sua dinâmica natural possibilitam à razão atuar sobre o desejo. Uma vez sabendo qual é a condição de possibilidade de o desejo ser educado, veremos como essa possibilidade se realiza em termos gerais e se expressa em cada virtude particular. 


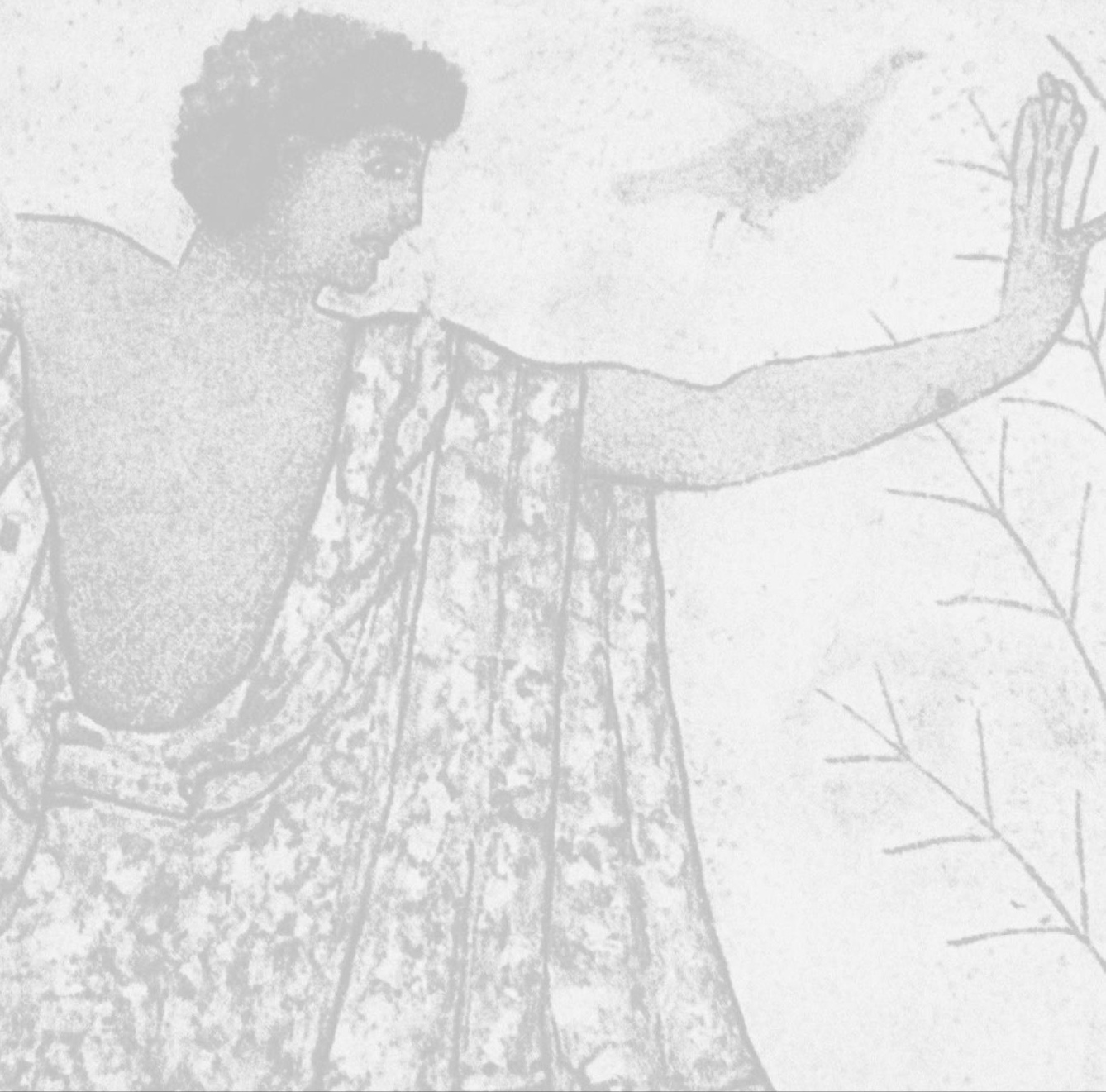

\section{PRIMIEIRA PARTE}

\section{O praver segunda Avistóteles}




\section{Análise conceitual do prazer}

Educar o desejo significa, sobretudo, se habituar a ter prazer com o que se deve e do modo que se deve. Digo sobretudo, pois, como veremos no decorrer deste livro, para Aristóteles, outros elementos são fundamentais para a educação do desejo e mesmo para que os bons hábitos sejam adquiridos, a saber: a força compulsória da lei, a força persuasiva do conselho do outro e a atuação da própria razão quando está já se tornou capaz de orientar corretamente o desejo.

Se educar o desejo significa, sobretudo, criar o hábito de ter prazer com o que se deve, como e quando se deve, então, compreender o desejo e, mais ainda, a educação do desejo, pressupõe o exame do conceito de prazer. Ademais, em algum sentido, ter prazer corretamente sinaliza o desejo correto (orthê) ou virtuoso. Tendo em vista o que foi dito, evidentemente, o prazer pode ser bom, caso contrário, Aristóteles não poderia ter concordado com Platão ao dizer que "é preciso ser educado de certo modo desde novo, para que se tenha prazer (chairen) e dor (lupeîsthai) com o que se deve: esta é a educação correta" (EN II, 3, 1104b11-12).

Eis dois pressupostos da educação do desejo segundo o filósofo estagirita: o desejo pode ser bom, uma vez educado, e, o prazer também pode ser bom, uma vez que é preciso sentir prazer corretamente. Se, ao contrário, nem o desejo, nem o prazer pudessem ser bons, se não pudéssemos ter desejo e prazer com o que é preciso ter e do modo com que é preciso ter, nenhuma educação moral seria possível nos termos de aquisição de virtude. 
Não parece ser sem relevância para o projeto educativo proposto pelo filósofo a sua concepção hedonista moderada, em que o prazer, embora não seja $o$ bem, possa ser um bem, uma vez que esteja acompanhando uma boa atividade. Certamente, o prazer não poderia ser o bem supremo, pois ele é causa necessária, mas não suficiente da felicidade, como é declaradamente dito no primeiro livro da Ética Nicomaqueia. ${ }^{1}$ Se o prazer fosse o bem, agir bem seria simplesmente perseguir tudo o que fosse prazeroso. Ora, a filosofia aristotélica nos alertou e nossa experiência ordinária continuamente nos mostra que nem sempre o que nos dá prazer é bom e deve ser perseguido.

Por outro lado, se o prazer fosse um mal em absoluto, ele não poderia ser considerado uma das causas da felicidade, e, se jamais pudéssemos ter prazer com o que é bom, com o que é preciso ter, tampouco poderíamos admitir que a educação correta é primordialmente uma educação dos prazeres. O projeto da educação moral, frente ao anti-hedonismo e ao hedonismo extremos, estaria fadado ao fracasso e já não poderíamos conceber a ética aristotélica como uma ética das virtudes. E uma ética das virtudes nada mais é do que uma ética que pressupõe a realização plena da natureza humana, isto é, que o homem possa vir a ser capaz de realizar da melhor maneira possível suas capacidades anímicas. Portanto, virtude nada mais é do que o excelente funcionamento de certa operação. E para a capacidade mais especificamente humana - a razão - possa operar da melhor maneira possível, o desejo deve ter sido educado previamente de modo a ser facilmente persuadido por ela. Para tanto, o prazer não pode ser um elemento desviante como comumente é para a maioria das pessoas.

Delineado este horizonte conceitual, no primeiro capítulo desta primeira parte, a nossa investigação consistirá em mostrar como Aristóteles critica as opiniões anteriores sobre o prazer de modo que ele possa defender a tese de que o prazer não é nem o bem nem o mal em absoluto, mas que, cumpridas certas exigências, ele possa ser considerado um bem. Assim, pretendemos verificar em que sentido a definição de prazer como uma atividade desimpedida é fundamental para refutar a tese anti-hedonista do prazer como sendo o mal em absoluto, conforme o primeiro tratado do prazer. Em seguida, mostraremos como a definição de prazer do segundo tratado do prazer - o prazer como uma atividade acompanhante de outra atividade - é necessária para evitar um possível hedonismo suscitado pela 
primeira definição, visto que a eudaimonia também é uma atividade desimpedida. Ademais, não deixaremos de elencar alguns dos principais problemas filosóficos suscitados a partir da análise de ambos os Tratados sobre o prazer.

Em seguida, no segundo capítulo desta primeira parte, nos dedicaremos a elaborar interpretações a respeito do que consideramos os principais problemas éticos que envolvem, primeiramente, o atributo do prazer como uma perfeição acrescida à boa atividade, isto é, como um efeito da boa atividade que retroage sobre a mesma aperfeiçoando-a. Nesse caso, como veremos, tal atributo parece valer apenas para o prazer que acompanha uma boa atividade. Outro problema fundamental cuja resolução permanecerá como objeto de incessante disputa nas questões de filosofia moral será a relação entre prazer e virtude. Que o prazer é um fenômeno de peso na conduta moral, é bem sabido por todos. A dificuldade, porém, reside em saber o quão determinante ele é para a aquisição e exercício da virtude.

Tendo em vista tanto a determinação da natureza, como o papel moral do prazer, far-se-á necessário esclarecer a relação entre desejo e prazer e, neste ponto, nos direcionaremos para uma tese de maior fôlego filosófico, a saber: a possibilidade da educação do desejo. Não se trata de dar conta dessa tese por inteiro neste primeiro momento, mas de esclarecer, a partir da concepção aristotélica de prazer, em que sentido o prazer constitui o desejo e em que sentido ele é peça chave na educação moral.

Perguntaremos pelo objeto de desejo: afinal, tudo o que é tomado como objeto de desejo também é objeto de prazer? Há uma coincidência necessária entre parecer ser bom (objeto de desejo) e parecer ser prazeroso (objeto de prazer)? Ou nem tudo o que parece ser prazeroso é objeto de meu desejo? Mais ainda: nem tudo o que desejo me parece ser prazeroso? O que me faz desejar algo coincide ou não com o que me apetece? A resposta de Aristóteles parece ser negativa por dois motivos. Em primeiro lugar, visto que há mais de um tipo de desejo e não apenas o desejo pelo prazeroso (epithumia), nem sempre o objeto de desejo coincide com o objeto de prazer, sobretudo no que concerne aos outros dois tipos de desejo: impulso (thumos) e querer (boulêsis). Em termos gerais, podemos dizer que o objeto do impulso é uma dor sofrida e do querer é o bem simplesmente. Em segundo lugar, é tese bem estabelecida na ética aristotélica, que o virtuoso não age por prazer, mas por algo ser verdadeiramente um bem, embora sinta prazer ao agir, isto é, não é por parecer ser prazeroso que o virtuoso o desejará, mas o que é preciso ser feito nas circunstâncias particulares: este é o bem segundo a verdade. Todavia, mesmo que o desejo reto ou virtuoso não seja aquele por um objeto simplesmente 
tomado como prazeroso, ainda assim, tudo o que ele deseja lhe agrada, pois a ação virtuosa necessariamente lhe aparece como prazerosa.

Veremos, com detalhe, que a causa constituidora do fim virtuoso é o que é verdadeiramente um bem, concebido assim pela reta razão, pois o que é de fato bom lhe aparece como um bem. A disposição de bem desejar consiste exatamente em desejar o que é verdadeiramente um bem. O bem aparente ou fenomênico, no caso do virtuoso, coincide com o bem em si mesmo. A condição para a sua apreensão correta está no uso correto da razão que tem em mira o meio termo nas ações e emoções e não no pensamento ou na percepção de algo prazeroso, embora aquilo que fora apreendido corretamente como um bem também lhe apareça necessariamente como algo prazeroso.

Assim, veremos que a manifestação prazerosa do bem não é condição de sua apreensão correta, mas sua consequência inevitável. Deste modo, não parece ser casual ou aleatório que o Estagirita tenha enfatizado diversas vezes que a educação moral seja, dentre outras coisas, passar a se habituar a ter prazer com o que é preciso ter, com o que é verdadeiramente bom. Em uma palavra: educar o desejo é, sobretudo, habituar-se com o que é bom, o que implica necessariamente aprender a ter prazer com o que é bom. Há, no caso do virtuoso, uma coincidência entre a apreensão correta do bem e a percepção do que é prazeroso: o bem apreendido é manifestamente prazeroso ao virtuoso.

\section{Análise do primeiro Tratado do prazer}

Entendemos como o primeiro Tratado do prazer aquele presente no livro VII da Ética Nicomaqueia (EN VII 11-14: 1152b1-1154b34), que é comum à Ética Eudêmia (EE), assim como os livros V e VI. Apenas o denominamos primeiro por ser primeiro na ordem da análise, e não por ser cronologicamente anterior ao segundo Tratado, pois parece não haver nenhuma informação contundente que possa datar os dois Tratados. Reconhecemos apenas, sem, contudo nos comprometermos com a interpretação, de que o livro VII, pelo fato de ser um livro comum e de estar estilisticamente mais próximo da $E E$, provavelmente pertença originalmente à $E E$, como supôs Kenny. ${ }^{2}$ Todavia, não pretendemos comprovar tal plausibilidade, mas apenas admiti-la como provável. Passemos à substância 
mesma: a análise conceitual do primeiro Tratado, de modo a evidenciar a concepção hedonista moderada de Aristóteles, sem deixar de trazer ao lume do texto os problemas implicados nesta concepção.

Após ter examinado o fenômeno do descontrole, do capítulo primeiro ao décimo do livro VII, que consiste justamente no fracasso moral diante da força do apetite por prazeres excessivos e contrários à reta razão, não é de se surpreender que o prazer e a dor, enquanto elementos constituidores e determinantes da ação moral, sobretudo do erro moral, sejam agora abordados por Aristóteles.

O primeiro Tratado tem por objetivo saber o que é o prazer e em que sentido ele é um bem. O seu objeto é o prazer por duas razões: a primeira é que toda emoção e toda ação são acompanhadas de prazer ou dor, portanto somos sempre, de alguma maneira, orientados a agir conforme o prazer e a dor que sentimos; uns mais, outros menos. Ou seja, o prazer funciona geralmente e para maioria das pessoas como uma espécie de fator motivador da ação ou medida determinante para se agir ou não, pois "medimos as ações, uns mais, outros menos, pelo prazer e pela dor" (EN II 3: 1105a4). A segunda razão é a de que "os prazeres e as dores nas ações são sinais das disposições” (EN II 3: 1104b4-5). Isso significa que ter prazer ou dor, ao agir desse modo ou de outro, sinaliza (semeion) o tipo de caráter de quem age. Em outras palavras, o prazer parece ser um sinalizador do tipo de caráter do agente.

Por essas duas razões - fator motivador, em geral, da ação moral e fator de reconhecimento do caráter do agente -, o estudo do prazer se faz necessário na medida em que o tipo de prazer que se sente revela, de algum modo, a disposição virtuosa ou viciosa do agente. Em poucas palavras, eis a justificativa aristotélica para a sua investigação sobre o prazer: visto que o caráter se constitui pela regularidade de ações e emoções e que estas são comumente motivadas pelo que tomamos como prazeroso, então devemos investigar o prazer.

No início do primeiro tratado, Aristóteles expõe as três opiniões conflitantes sobre o valor moral do prazer. A primeira é a de que o prazer deve ser evitado absolutamente, visto que é um mal per se ou per accidens. Esta posição radicalmente anti-hedonista, como veremos, será a de Espeusipo (1153b57). A segunda afirma que o homem deve dominar, controlar, refrear os seus apetites (epithumiai), ${ }^{3}$ visto que, senão todos, com certeza a maioria dos pra-

3 Gostaria de esclarecer, por questão de convenção, que optei traduzir o termo orexis por desejo; boulêsis por querer; epithumia por apetite, e thumos por impulso. 
zeres é má. Esta opinião, também anti-hedonista, embora não extremada, se justifica pelo fato de haver prazeres que são vergonhosos e censuráveis, bem como outros tantos que são nocivos (1152b21-22). A justificativa parece referir-se à concepção que Platão expressa em seu diálogo Filebo, ${ }^{4}$ ao dizer que a maioria dos prazeres nocivos é corporal e envolve dor. Por fim, a terceira opinião expressa uma posição menos radical, que também aparece no final do diálogo referido ${ }^{5}$ e com a qual parece concordar Aristóteles em seu segundo Tratado, é a de que o prazer não poderia ser o bem supremo, mesmo que todos os prazeres fossem bons. Esta última opinião, que pode ser entendida como hedonista moderada, se contrapõe à concepção hedonista extremada sustentada por Eudoxo (EN X 2, 1172b9), que acredita que o prazer seja o bem por excelência.

Resumidamente, há três opiniões que serão examinadas e criticadas por Aristóteles para que o mesmo possa chegar à sua própria concepção de prazer neste primeiro tratado, a saber: uma opinião radicalmente anti-hedonista, outra anti-hedonista simplesmente, e, uma terceira, por assim dizer, hedonista moderada, e mais próxima do que pensa o filósofo estagirita. ${ }^{6}$ A opinião hedonista extrema de Eudoxo será examinada apenas no segundo tratado, como veremos.

O principal objetivo deste primeiro Tratado é refutar a visão radicalmente anti-hedonista com vistas a demonstrar que a felicidade pressupõe o prazer e que, portanto, o bem supremo não poderia incluir um mal em sua constituição;

4 Para Gauthier (2002), esta segunda opinião seria platônica, pois Platão, em Filebo (50e - 53c; 66c), diz que os bons prazeres são apenas os da alma - aqueles que não envolvem dor, são puros, imaculados e suficientes, isto é, não carentes ou deficientes em sua natureza. São também moderados, poucos, belos e mais próximos da verdade. São os que nascem da apreensão das formas geométricas, de belas cores, de muitos odores e de sons suaves e límpidos, próprios de uma melodia pura e única, e, sobretudo, o prazer da aprendizagem que não sejam provenientes da fome de apreender. Em suma, os prazeres puros são aqueles que acompanham o conhecimento e algumas sensações. Já os prazeres ruins são aqueles que envolvem dor por serem extremos ou desmedidos, e esses são grandes e numerosos, pois constituem a maioria dos prazeres corporais, principalmente os sexuais.

5 Cf. Filebo 60d-61b, em que Platão propõe que a vida feliz seja mista entre prazer e inteligência. Aristóteles atribui textualmente a Platão esta terceira opinião em EN X 2: 1172b29.

6 Tomás de Aquino (1993, § 1481), Festugière (1946) e Joachim (1951) atribuíram esta terceira opinião a Aristóteles. Riel (2000), por sua vez, critica tal atribuição, pois a justificativa do prazer não ser o bem supremo é a de que ele é um processo (genesis), o que certamente não pode ser um argumento aristotélico. Acresce, ainda, que esta concepção é antes de Platão do que de Aristóteles. Em concordância com Riel, dizemos que ela se aproxima apenas no que diz respeito à sua postulação, isto é, o prazer não é o bem, embora possa ser um bem; porém, a sua justificativa não pode ser aristotélica. 
por este motivo, o prazer deve ser considerado um bem. Isso significa que a concepção anti-hedonista está, por assim dizer, mais distante da verdade do que a concepção hedonista. Prova disto é o fato de Aristóteles fazer uso do mesmo argumento do qual parte Eudoxo ${ }^{7}$ para fundamentar o seu hedonismo, a saber: o prazer é naturalmente perseguido por todos os animais. Ora, conceber que a natureza do animal busca algo que seja um mal para si parece ser um contrassenso factual e teórico, pois sabemos que, para o filósofo, a essência (ê̂dos) de cada coisa busca naturalmente o seu bem próprio. É evidente, aos olhos de quem examina com a atenção este primeiro tratado, que o principal alvo de Aristóteles é a concepção anti-hedonista. Para atingir o seu alvo, ele expõe os argumentos que sustentam tal concepção no capítulo 11, e, no capítulo seguinte, passa a refutá-los.

A opinião de que o prazer não é um bem nem em si mesmo (per se), nem por acidente (per accidens), pretende se sustentar pelas seguintes razões: em primeiro lugar,

(i) como o prazer é um processo sensível (genesis aisthêtê) com vistas à natureza, e (ii) o processo é distinto do fim do processo, pois o processo existe em vista do fim que, por sua vez, existe em vista de si mesmo; (iii) o fim deve ser concebido como o bem ao qual visa o processo. Por esta razão, o processo não é um bem e o prazer, sendo um processo, tampouco poderia ser um bem. ${ }^{8}$ Em segundo lugar, (i) como o temperante (sôphrôn) evita os prazeres ${ }^{9}$ e (ii) é ele quem serve de modelo para a busca do bem; por isso, o prazer não deve ser considerado um bem. A terceira razão é a de que o prudente (phronimos) busca o que não é penoso, e não o que é prazeroso, logo, (i) se o prudente busca o bem e (ii) este é

7 Cf. ENX 2: 1172b9-10 e I 12: 1101b27-31.

8 Esse argumento certamente é de Platão, pois está presente em Filebo 53c-55c. Riel (2000, p. 47) e Frede (2005, p. 189) também localizam o argumento no diálogo referido. Ver também MM II 7: 1204b4-1205a7. O argumento, a meu ver, não parece ser fiel ao que procurou dizer Platão, pois, ainda que, segundo o mesmo, alguns sábios tenham dito que o prazer, em geral, é devir, a sua própria concepção não seria a de que todo prazer seja ruim por ser um vir a ser, mas apenas os impuros, aqueles que são misturados com a dor, que são um processo sensível de restauração do estado natural, pois nascem de um estado dolorido de falta ou carência; esses são, comumente, os prazeres do corpo. Aos olhos do filósofo estagirita, porém, Platão estaria se referindo a todo prazer e não apenas ao corporal.

9 É provável que este argumento se refira ao diálogo Fedon (68c) de Platão, no qual ele afirma que o temperante evita os prazeres corporais, enquanto o intemperante busca tais prazeres a ponto de se tornar escravo deles. Mais uma vez, Platão estaria criticando apenas o prazer corporal e não todo e qualquer prazer, como parece pressupor Aristóteles. Sobre este ponto ver também Frede (2005, p. 190). 
antes o que não é penoso do que o que é prazeroso, conclui-se que buscar o bem é evitar o que é penoso e não perseguir o prazeroso. A quarta razão é a de que o prazer é um impedimento do exercício do pensamento, ${ }^{10}$ e se o impede, então ele deve ser considerado não acidentalmente, mas essencialmente um obstáculo para a realização da prudência. Assim, (i) se prazer é um impedidor da prudência e (ii) nada que seja bom a impediria, então o prazer não poderia ser um bem. A quinta razão é a seguinte: (i) como todo bem é produzido por uma arte (tech$n \hat{e})$, e (ii) não há arte que produza o prazer, segue-se que o prazer não poderia ser um bem. ${ }^{11}$ A sexta e última razão é a de que, (i) como as crianças e os animais perseguem os prazeres e (ii) eles não são capazes de perseguir o bem que deve ser perseguido para o ser humano, isto seria um sinal de que o prazer não poderia ser um bem ou o bem supremo.

Em seguida, no capítulo 12, Aristóteles passa a refutar tais opiniões anti-hedonistas. A refutação da opinião de que o prazer não é um bem se baseia no argumento de que mesmo que o prazer seja um processo (genesis), ainda assim é um erro dizer que ele não é um bem. Com efeito, cometem tal erro aqueles que ignoram as seguintes distinções. Em primeiro lugar, assim como o bem tem um sentido duplo, isto é, absolutamente (haplôs) ou relativamente (tini), o seu contrário, o mal, também o terá. Em segundo lugar, as naturezas (phuseis) e as disposições (hexeis), quando aplicadas às categorias de bem ou de mal, estão abertas a esse duplo sentido, bem como os movimentos (kineseis) e os processos (geneseis). Isso porque esses, por provirem de naturezas ou disposições particulares, também receberiam tais atributos.

É preciso, para o Estagirita, estabelecer certos matizes à concepção do prazer como um processo. Em primeiro lugar, alguns processos tidos como maus absolutamente, podem ser bons relativamente e de fato escolhidos por alguém. ${ }^{12}$ Em segundo lugar, certos processos não são bons em absoluto, pois

10 EN VII 11: 1152b16: "empodion toi phronein hai hêdonai". Esta também parece ser uma concepção do diálogo Fedon (66c) de Platão, pois, o fato de os prazeres impedirem o pensamento, como aqueles próprios do estado apaixonado, justifica a tese de que seria um bem para alma se libertar do corpo.

11 Esse argumento parece se referir ao diálogo Górgias (462a-465d) de Platão, em que a retórica e outras habilidades como a de cozinhar não são consideradas verdadeiras artes (technai), pois não produzem um bem, mas apenas bens aparentes que servem apenas para deleitar. Ver também Frede (2005, p. 191).

12 Aristóteles não nos fornece nenhum exemplo, mas poderíamos pensar em um remédio que, embora não seja em absoluto ou sem qualificações algo bom, ele certamente é bom para um paciente 
não são desejados em si mesmo, e nem relativamente, isto é, não são geralmente desejados por alguém, embora possam ser desejados por alguém, em certa circunstância, e por certo tempo. Por isso, o Estagirita nos diz que eles são maus em absoluto e, em geral, relativamente, mas não em determinada circunstância e por certo tempo. ${ }^{13}$ A diferença entre o primeiro caso e o segundo, é que no primeiro o processo pode ser regularmente bom para determinadas pessoas; já no segundo, o processo pode ser eventual e pontualmente bom para determinadas pessoas em situações extremas. Em terceiro e último lugar, alguns processos não são de modo algum bons e, portanto, não são realmente, mas apenas aparentemente prazerosos, pois são acompanhados de dor e são buscados como remédios para aliviarem a dor.

Com tais distinções, o filósofo refuta a tese de que o prazer não poderia ser considerado um bem, mesmo que ele seja compreendido como um processo ou movimento. O cerne da refutação encontra-se no argumento de que o processo também pode ser considerado um bem, senão em absoluto, ao menos relativamente. Donde se conclui que dizer que o prazer é um processo não implica necessariamente dizer que ele não seja um bem, pois, mesmo que ele seja em absoluto um mal, ainda assim ele poderia ser relativamente um bem. Em suma, como acabamos de ver, a partir do duplo sentido de bem e mal - absoluto e relativo -, o filósofo refuta a tese de que o prazer deve ser tomado como um mal em absoluto se identificado a um processo.

Em seguida (1152b33-1153b8), o filósofo pretende estabelecer em qual sentido o prazer pode ser um bem. Para tanto, é preciso antes conceber o que é o bem. Certamente, para que o prazer possa ser um bem, não poderá prevalecer a concepção de Platão de que ele é um processo de restauração (kathistasai) ao estado natural perfeito, estado em que não há carência ou falta, ou seja, o prazer

que o necessite em seu tratamento. Outro exemplo ainda mais esclarecedor é o ato de amputar uma parte do corpo, pois a amputação pode ser boa para um corpo doente no sentido de evitar o falecimento do indivíduo, mas ela não poderia ser boa para o corpo em sua perfeita condição de natureza, para o corpo enquanto tal, o corpo sadio. Neste sentido, o processo de amputação não poderia ser bom em termos absolutos.

13 Aristóteles tampouco nos oferece um exemplo que ilustraria uma situação deste tipo, mas poderíamos supor que, por exemplo, não é bom em absoluto comer algo que ninguém, por princípio, comeria, nem mesmo uma pessoa em particular, mas apenas em uma situação de extrema necessidade, como seria o caso em que é preciso comer carne humana para sobreviver quando não há outra fonte de alimento. Tomás de Aquino (1993, § 1485) também exemplifica este caso com o ato de comer algo por extrema necessidade. 
é um mero preenchimento de um vazio ou uma falta dolorosa, portanto intrinsecamente misturado com dor. ${ }^{14}$

A resposta a esta objeção de caráter platônico surge inesperadamente, sem justificativas ou pormenores aparentes. Aristóteles parte do pressuposto de que o bem é tanto uma atividade (energeia), como uma disposição (hexis). ${ }^{15}$ Com o intuito claro de refutar Platão, Aristóteles concebe o prazer não como um processo, mas como uma atividade ou uma atualização (energeia) que pode acompanhar um processo. Neste caso, enquanto acompanhante de um processo, deve-se dizer que ele é acidental, e, enquanto uma atividade, que ele é real.

Segundo o filósofo, o prazer acidental é aquele que sentimos quando estamos em processo de restituição ou reabilitação de nosso estado natural. Por isso, devemos entender tal prazer como sendo concomitante (kata sumbebêkos) ao processo restaurador de nossa natureza (1152b34-35). Com efeito, um prazer sentido por alguém em estado de reabilitação não pode ser prazeroso em absoluto, sem qualificações (haplôs), ou por natureza (phusei) (1153a6). Por exemplo, ninguém sentiria prazer com algo extremamente ácido ou amargo a não ser que esteja doente. Tampouco alguém sentiria prazer em se aquecer com uma manta em um ambiente quente, a não ser que se esteja febril. Por isso, este tipo de prazer só pode ser assim considerado apenas relativamente a alguém que esteja doente ou em estado de debilidade e não em termos absolutos, isto é, ele não pode ser dito naturalmente prazeroso, mas sim acidentalmente, ou melhor, concomitantemente ao processo de superação do estado de debilidade. Por isso, os prazeres que acompanham a convalescença não são em si mesmo prazerosos, mas apenas para aqueles que se encontram em tal estado.

14 A definição do prazer como um mero preenchimento de uma falta dolorosa encontra-se no diálogo Górgias, 496c-500e. Também em Filebo, 31 d-32a, o prazer impuro - misturado com a dor - consiste na reparação de um equilíbrio ou no preenchimento de uma falta. Os exemplos que Platão costuma usar são os processos de saciação da fome e da sede. Em MM II 7, Aristóteles faz referência explícita ao fato de que a concepção platônica do prazer como um processo sensível, portanto, corporal, implica pressupor que o prazer surge da dor por um excesso ou falta no corpo, pois, "como a falta e o excesso são penosos; então, onde o prazer surge há dor” (1204b12). Ver também o texto em que Dorothea Frede descreve as várias concepções de prazer nos diálogos de Platão (2009, p. 236-253).

15 Veremos que, no segundo Tratado do prazer, a atividade não será tida como um bem sem mais, pois ela poderá ser boa ou má a depender das circunstâncias em que seja realizada. Ademais, será o julgamento sobre o valor moral da atividade realizada pelo agente moral que servirá de critério avaliativo do prazer e não o fato de ele ser uma atividade que determinará sua boa qualidade moral. 
Há, portanto, dois momentos distintos: um em que o estado de natureza está debilitado e o que é bom ou prazeroso diverge do que comumente se julga ser bom e prazeroso; e outro momento em que o estado é aquele em que a nossa natureza física e psíquica se encontra em sua perfeita condição, e o julgamento sobre o que é bom e prazeroso pode expressar o bem e o prazer por natureza. Ou seja, uma pessoa virtuosa e saudável certamente encontra seus prazeres no que é por natureza prazeroso. Como nos diz o filósofo:

Uma indicação de que o prazer é acidental é que nós não fruímos das mesmas coisas quando nosso estado natural está em processo de reabilitação como quando já está reabilitado. Neste último caso, fruímos de coisas que são prazerosas em absoluto; mas durante a reabilitação, fruímos até mesmo de seus contrários. Por exemplo, o ácido e o amargo não são nem por natureza nem absolutamente prazerosos, tampouco são os prazeres por tais coisas (EN VII 12: 1153a3-6).

Como define Aristóteles, o prazer natural é próprio da "atividade dos apetites que pertence à disposição e à natureza que permaneceram preservadas (hê energeai hen taîs epithumiais tês hupoloipou hexeôs kai phuseôs)" (1152b35-36). Com efeito, sentimos prazer quando atualizamos nossas potencialidades naturais, sejam elas vegetativas, perceptivas ou intelectivas, isto é, quando exercemos atividades próprias à nossa natureza em estado de não debilidade ou carência física (como uma doença), ou psicológica (como uma loucura, bebedeira ou outro estado de perturbação psíquica) (tês phuseôs ouk endeoûs ousês) (1153a2); mesmo que tal natureza seja apenas uma parte ainda saudável em um indivíduo convalescente. Ou seja, mesmo em um estado de debilidade, o prazer que sentimos é próprio da atividade do que permaneceu saudável e apenas concomitante ao processo de reabilitação, portanto, podemos dizer que tais prazeres acidentais são restauradores. Nas palavras do filósofo:

Os prazeres sem dor não admitem excesso. E tais prazeres são por natureza e não por acidente. Chamo de prazeres por acidente aqueles que são restauradores (ta iatreuonta). Isso porque o ato de restaurar ocorre por meio da ação do que permaneceu saudável; por isso <o processo $>$ parece ser prazeroso. Assim, o prazer por natureza é aquele que produz uma ação de uma natureza < saudável> (EN VII 14: 1154b16-21). 
Isso significa que o prazer é sempre uma atividade ou atualização do que há em nós de saudável ou perfeitamente natural; todavia, ou estamos plenamente saudáveis de modo que o prazer será simplesmente natural, ou estamos doentes e o prazer será tanto uma atividade conforme o que nos resta de saúde, como um concomitante de um processo de convalescença. Neste último caso, ele pode ser dito tanto natural, como acidental ou concomitante.

Desse modo, o prazer que ocorre concomitantemente à convalescença não pode ser identificado ao processo de convalescer. Tampouco poderíamos reduzir todo prazer à categoria de acidental. Afinal, há prazeres absolutamente naturais e há prazeres que são tanto naturais como acidentais. Não há prazer que seja apenas acidental. Durante a convalescença, a parte saudável entra em atividade e é acompanhada de um prazer próprio ao seu exercício e não acidental a ele. Nas palavras do filósofo:

Com efeito, os prazeres não são processos (genesis), nem todos ocorrem junto a processos: eles são atividades (energeiai), i.e., fins (telos). Tampouco eles surgem quando estamos nos tornando algo, mas quando estamos exercitando alguma faculdade. E nem todo prazer tem um fim distinto dele mesmo, mas apenas aquele de quem está se direcionando para a perfeição de sua natureza (1153a10-13). ${ }^{16}$

Ou seja, no convalescente, o prazer tem outra finalidade que não ele mesmo: a de aliviar a dor; enquanto no saudável, a finalidade é o próprio ato de ter prazer ao atualizar qualquer faculdade ou capacidade, isto é, ao exercer qualquer que seja a atividade, desde que ela seja saudável. Por isso, a afirmação de que o convalescer é prazeroso pode ser enganadora. Ora, se o próprio convalescer fosse prazeroso, todos nós quereríamos naturalmente adoecer, o que não é o caso. Todavia, como é inegável que temos prazer durante a convalescença, Aristóteles se põe a explicar que tal prazer não o próprio processo de convalescer, mas sim

16 Quanto ao trecho "all energeiai kai telos", cabe sinalizar que compreendemos o kai desta frase como expletivo e o traduzimos como isto é. Isso porque o prazer é identificado com a atividade e ela é o seu próprio fim, ao contrário do processo, cujo fim lhe é extrínseco. Cabe notarmos que, no segundo tratado, a definição de prazer também será a de um fim ou perfeição (ti telos), portanto, uma atividade, visto que energeia e telos são o mesmo. Mais uma vez, podemos dizer que há um compartilhamento de conceitos nos dois tratados, mesmo no que diz respeito à definição de prazer: em ambos os tratados, o prazer é uma atividade. 
a atividade que permaneceu saudável no organismo e que, enquanto acompanhante de tal processo, ele é acidental.

Por exemplo, quando dizermos que "um músico fez esta estátua”, devemos entender que ele a fez não enquanto músico, mas enquanto escultor. Para expressarmos em termos aristotélicos esta explicação, deveríamos dizer que "um músico fez acidentalmente esta estátua”, compreendendo acidentalmente como não sendo próprio da natureza de $A$ fazer $B$, isto é, não é próprio da natureza do músico fazer esculturas. Dizer que não é próprio da natureza de $A$ fazer $B$ não é o mesmo que dizer que é eventual ou excepcional à sua natureza (este também é um dos sentidos de "por acidente"). ${ }^{17}$ Analogamente, se dizemos que “o convalescer é acidentalmente prazeroso", devemos entender acidentalmente como não sendo próprio da natureza do convalescer ser prazeroso ou que não é enquanto um convalescer que este processo é prazeroso. Enfim, os argumentos do filósofo estagirita, como vimos, nos conduzem à seguinte conclusão: se o prazer não é um processo, então ele é uma atividade. Se ele é uma atividade, então ele é um fim em si mesmo, uma perfeição, um acabamento (telos), e não um processo cuja natureza é inacabada e cujo fim lhe é extrínseco. Nesse sentido, ele pode ser considerado um bem em termos absolutos e não apenas relativa e acidentalmente.

Em resumo, vimos até o momento que o prazer que acompanha um processo (genesis) ou movimento (kinêsis) de restauração, como a convalescença, deve ser entendido como acidental. Esse prazer não é ele mesmo um processo, mas uma atividade. Em poucas palavras: a diferença entre o prazer acidental e o natural, é que o primeiro é uma atividade que acompanha um processo "restaurador (kathistâsai) do estado de natureza" (1152b34), enquanto o segundo é uma atividade própria ao estado de perfeita saúde.

Isso significa dizer que, ao contrário do que acreditava Platão, o processo não pode ser essencialmente prazeroso, mas apenas acidentalmente por ocorrer em concomitância a certos prazeres. É evidente que, aos olhos do Estagirita, a natureza do prazer não poderia ser definida pelo que lhe é acidental, e, por isso mesmo, Aristóteles fornece a sua definição de prazer corrigindo a de Platão: ${ }^{18}$

17 Ver Met. V 30 e VI 2 sobre os dois sentidos de kata sumbebêkos (como ocorrendo excepcionalmente ou como não sendo por natureza); já para saber mais de sua aplicação para a interpretação do prazer acidental, ver Owen (2010, p. 93-94). 
Portanto, não é correto dizer que o prazer é um processo sensível, mas antes é preciso dizer que ele é uma atividade do estado natural (energeian tês kata phusin hexeôs) e substituir 'sensível' (aisthêtên) por 'desimpedida' (anempodiston) (1153a13-15). ${ }^{19}$

Com tal definição, Aristóteles finaliza sua refutação da concepção platônica de prazer como um processo sensível de preenchimento de uma falta dolorosa, falta esta própria a um estado de carência ou de privação. Aos olhos do filósofo estagirita, duas substituições devem ser feitas: em primeiro lugar, o prazer não é um processo, mas uma atividade, ou seja, ele não é um restaurador do estado de natureza, mas a realização de uma atividade própria a tal estado. Em segundo lugar, ele é desimpedido e não sensível, visto que qualquer atividade, sensível ou intelectiva, pode ser prazerosa e não apenas sensível. Logo, a condição para ser prazerosa não é que a atividade seja sensível, mas que ela seja desimpedida, visto que qualquer impedimento ao seu exercício também obliteraria a fruição do prazer e seria sempre sentido como penoso. ${ }^{20}$

Em seguida, Aristóteles continua a refutar outros argumentos anti-hedonistas. Em 1153 a 18-21, a opinião de que os prazeres são ruins pelo fato de haver algumas coisas prazerosas que são nocivas não se sustenta. Isso porque o fato de ser nocivo não torna má a própria natureza da coisa nociva. Seria o mesmo que dizer que a saúde não é boa por despender gastos. Mesmo que, para se recobrar a saúde, seja preciso fazer algo "ruim”, como gastar dinheiro com remédios custosos, nem por isso se curar seria ruim.

Se o que é nocivo não é necessária e absolutamente ruim, também o que é bom não é necessária e absolutamente inócuo. Mesmo que algo seja em si

19 A definição se repete no capítulo seguinte, em 1153b12.

20 Cf. EN VII 13: 1153b2-3. Outro trecho nos fornece explicitamente o que seriam alguns impedimentos (empodioi): "como nenhuma atividade impedida é perfeita e a felicidade é uma atividade perfeita, o homem feliz necessita de bens do corpo, externos e da fortuna (tuchês), de modo que ele não seja impedido por eles" (EN VII 13: 1153b17-19). Nesse sentido, o impedimento seria ou corporal ou extrínseco à própria realização da atividade. Riel, por sua vez, compreende que o impedimento pode ocorrer tanto por parte do objeto como do sujeito; logo, o desimpedimento é a conjunção da faculdade e de seu respectivo objeto quando ambos se encontram em perfeitas condições. O exemplo que ele fornece é o seguinte: "Quando meu ouvido, por exemplo, ouve belos sons de modo perfeito, sua atividade de ouvir frui um prazer específico (e o mesmo para as outras faculdades). Ouvir, por sua vez, perfeitamente sons desagradáveis não é prazeroso, tampouco o é ouvir de modo imperfeito belos sons” (RIEL, 2000, p. 51, tradução nossa). Farei, mais adiante, no comentário ao capítulo 13 do livro VII, uma análise detalhada deste atributo “ser desimpedida” próprio à definição de prazer. 
mesmo bom, ele pode ser, em algum sentido, nocivo. O exemplo fornecido por Aristóteles certamente espantaria Platão: a contemplação, quando excessiva, pode ser nociva à saúde. A contemplação, que é, por natureza, prazerosa, saudável e boa pode ser nociva ou ruim sob certo aspecto, mas isso não a torna essencialmente ruim.

Quanto à opinião de que o prudente evita os prazeres, pois que eles impedem o pensar (1153a21-24), Aristóteles a refuta dizendo que os prazeres próprios do pensar não o impedem, mas apenas aqueles que lhe são alheios (1153a22). Ao contrário, eles nos fazem pensar e aprender mais (mâllon ) ${ }^{21}$ Logo, nada justificaria a opinião de que o prudente evita os prazeres; certamente, o prazer próprio ao pensar não seria evitado, ao contrário, seria por ele buscado.

Aristóteles concorda com a opinião de que não há arte que produza o prazer, porém nos diz que certas artes podem produzir produtos que nos dão prazer. De fato, não há uma arte do prazer, mas tampouco a arte é necessária para a produção de prazer. Ora, a arte não produz prazer, porque ela não produz atividades e sim capacidades (dunameos), isto é, objetos capazes de gerar prazer. Mesmo que as artes da perfumaria e da culinária sejam geralmente consideradas artes do prazer, elas não são capazes de gerar prazer, mas antes de produzirem produtos que podem nos dar prazer. Do mesmo modo com relação às outras artes: elas produzem produtos que, por exercerem certa função para o bem do homem, comumente nos dão prazer. Por fim, conforme o curto comentário de Aristóteles sobre essa opinião, podemos inferir que não é a arte que fabrica o prazer e que a opinião de que não há arte que produza o prazer está correta, mas isso não implica que o prazer não possa ser um bem, pois o bem não se reduz a bons produtos. Já fora dito pelo filósofo que o prazer não é um produto, mas uma atividade, e a atividade é um bem desejado por si mesmo; logo, ele é um bem que pode ser desejado por si mesmo. ${ }^{22}$

21 Dizer que o prazer próprio ao pensamento nos faz pensar e aprender mais fornece um atributo essencial do prazer presente no segundo Tratado, a saber: o prazer é aquilo que, quando próprio à atividade, é capaz de aperfeiçoá-la. Ademais, também está presente aqui a distinção entre prazer próprio e prazer alheio à atividade que será usada no segundo Tratado (X 5: 1175a30-b33). Isso indica o compartilhamento de certos conceitos e desfavorece a interpretação de que não haveria continuidade alguma entre os dois Tratados.

22 Quanto a este último argumento, ver Tomás de Aquino (1993, § 1496). Sobre a distinção entre produção (poiêsis) e ação (praxis), que é um tipo de atividade cujo fim é ela própria, ver EN VI 4. 
O capítulo 12 termina com a refutação das seguintes opiniões exibidas no capítulo anterior, a saber:

1. a opinião de que o homem temperante evita os prazeres e busca um estado de ausência de dor;

2. a de que o prudente persegue o que não é penoso; e

3. a de que as crianças e os animais perseguem os prazeres e não o bem.

Aristóteles as refuta com base em um único argumento: mesmo que nem todos os prazeres sejam bons, alguns prazeres são absolutamente bons. ${ }^{23}$

Os prazeres que as crianças e os animais perseguem, mas que o prudente não persegue e o temperante evita são aqueles que o Estagirita chama de "prazeres corporais que envolvem apetite e dor (pois esses são desse tipo), isto é, os que são excessivos, aqueles com relação aos quais o intemperante é dito intemperante" (1153a32-34). Vemos aqui, explicitamente, Aristóteles utilizar o mesmo critério de Platão que estabelece, em seu Filebo 36c-50e, que o prazer ruim ou falso é o prazer impuro, ou seja, misturado com dor, e este comumente é corporal e excessivo. A diferença, porém, é que se para Platão a maior parte dos prazeres corporais é ruim, para Aristóteles, o prazer corporal não é nem bom nem ruim, mas quando ruim, certamente envolve dor e excesso.

Segundo o Estagirita, em EN VII 4 1148a22-b5, os prazeres corporais são, por princípio, necessários e neutros, ou seja, eles não são em si mesmos nem bons nem ruins, mas, quando excessivos, envolvem dor, portanto tornam-se ruins. Isso significa que o prazer corporal não é nem absolutamente ruim, nem absolutamente bom, mas é ruim apenas relativamente, seja quanto ao seu objeto, quando impróprio, seja quanto ao modo deste objeto ser desejado, quando excessivo. No caso dos adultos, são os prazeres corporais em excesso que provocam a dor da qual quer se ver livre o prudente e que fazem do homem um intemperante.

Em EN III 12, Aristóteles nos diz que a gênese da intemperança está nas crianças que não foram educadas de modo a controlarem seus apetites. Logo, se há uma tendência natural de vivermos segundo os apetites, deve-se educar a criança para que ela se torne obediente, pois "em um ser que não pensa, o desejo pelo prazer é insaciável e indiscriminado, e a prática de apetites aumenta a tendência inata, e se são grandes e intensas sucumbem o raciocínio" (1119b8-12). 
Ora, quanto mais tivermos apetites excessivos, menos seremos capazes de agir em conformidade com a razão, por isso a educação que disciplina e controla os apetites, tornando-os poucos e moderados é fundamental para que a criança não se torne um adulto intemperante.

Em suma, tudo o que o filósofo estagirita parece querer é evitar uma concepção essencialista do valor moral do prazer corporal, visto ser este o alvo predileto de Platão. Ele nos mostra que os prazeres corporais não podem ser considerados bons ou maus sem qualificação, pois eles são bons se moderados e ruins se excessivos. Nem todo prazer corporal é excessivo, obviamente, mas apenas ou sobretudo aquele que é perseguido pelo intemperante e evitado pelo temperante. Segundo o filósofo: "temperança e intemperança concernem a tais prazeres de que participam os animais inferiores e, consequentemente, parecem servis e bestiais; e estes são os prazeres do tato e do gosto" (EN III 10: 1118a2427). Os prazeres relativos ao tato e ao gosto, isto é, à comida, à bebida e ao sexo são mais suscetíveis ao excesso e, quando excessivos, são censuráveis por nos pertencer não enquanto somos homens, mas animais. Ou seja, trata-se de um comportamento antes bestial do que propriamente humano se comprometer, sobretudo, com esses prazeres e desejá-los acima dos outros (1118b3-4).

Depois de ter refutado, no capítulo 12 , as opiniões que negam a possibilidade de o prazer ser um bem e estabelecer que ele é um bem por ser uma atividade e não um processo, Aristóteles, no capítulo seguinte, pretende refutar àqueles que dizem que o prazer não poderia ser o bem supremo e acaba, como veremos, assumindo, de modo hipotético ou dialético, uma tese hedonista radical - a de que o bem supremo poderia ser um prazer - a título de refutação ao anti-hedonismo.

O capítulo 13 inicia-se com a exposição de uma espécie de disputa entre dois argumentos contrários: um argumento hedonista atribuído a Eudoxo ${ }^{24}$, e outro anti-hedonista atribuído a Espeusipo (1153b1-7). O argumento de Eudoxo é o seguinte: o prazer é um bem (agathon ti), já que todos concordam que o seu oposto, a dor, é um mal. A refutação de Espeusipo inicia-se com a afirmação que são dois os opostos do maior: o menor e o igual. Analogamente, ainda que a dor seja um mal, o oposto da dor pode ser tanto o prazer, como um estado neutro: nem doloroso, nem prazeroso. Por isso, que o prazer seja oposto à dor não 
decorre necessariamente que ele seja um bem, pois o estado neutro, também ele oposto à dor, pode ser um bem. Com efeito, Espeusipo parece ter afirmado que a felicidade consiste em uma vida neutra, livre de perturbações advindas do prazer e da dor. ${ }^{25} \mathrm{O}$ bem, portanto, estaria localizado entre dois males: a dor e $\mathrm{o}$ prazer, e deveria ser um estado de neutralidade ou tranquilidade.

Todavia, mesmo que Espeusipo assuma que o prazer seja um mal, ainda assim, o Estagirita supõe que, por mais anti-hedonista que seja sua opinião, ele não poderia assumir que o prazer seja essencialmente ou intrinsicamente um mal (hoper kakon ti). De fato, parece no mínimo estranho ou um contrassenso assumir que aquilo que todos buscam seja essencialmente um mal. É possível que nem mesmo Espeusipo o concebesse como um mal per se, pois o prazer seria ruim não em si mesmo, mas na medida em que causasse perturbações. ${ }^{26} \mathrm{De}$ todo modo, a explicação de Espeusipo não se sustentaria diante do julgo de Aristóteles, pois "é evidente que os homens evitam a dor como um mal e buscam o prazer como um bem; logo, prazer e dor são antípodas” (EN X 2: 1173a12-13). Não haveria, pois, uma dupla oposição do prazer em relação à dor e ao estado neutro, mas apenas uma oposição de mão dupla: prazer versus dor.

Em seguida (1153b7-13), depois de ter demonstrado que o argumento de Espeusipo é falho e que, portanto, a visão hedonista parece estar mais próxima da verdade, o filósofo passa a refutar a opinião anti-hedonista de que o prazer não poderia ser o bem supremo. Sabemos que, no livro primeiro da Ética Nicomaqueia, ele critica explicitamente a opinião da maioria que crê que a vida prazerosa é a vida feliz. Embora o prazer não seja o bem supremo, certamente ele não deixaria de ser uma das causas necessárias da felicidade (eudaimonia). Por isso, Aristóteles não passará a defender que um tipo de prazer pudesse ser o bem supremo, senão a título de refutação. Entendemos com isso, que ele não assumirá como tese própria, mas adotará a hipótese de que o bem supremo poderia ser um certo prazer, mesmo que a maior parte dos prazeres seja ruim, tendo

25 Segundo Clemente de Alexandria, Espeusipo dizia que os homens bons visam à ausência de perturbação (aochlêsias) (Stromata II 22). Sobre tal referência, ver Rapp (2005, p. 211). Em EN II 3, depois de ter mostrado que o modo indevido de buscar e evitar os prazeres e as dores tornam os homens torpes, Aristóteles, provavelmente fazendo referência a Espeusipo, diz que "é por isso que também definem as virtudes como certas impassibilidades e quietudes" (1104b24-25), criticando-o em seguida.

26 Quanto a esse ponto, não podemos formular senão conjecturas. Para saber mais, veja Rapp (2005, p. 213-214). 
em vista única e exclusivamente refutar a concepção anti-hedonista que diz exatamente o contrário.

Para defender tal hipótese, o filósofo faz uso de dois argumentos. O primeiro afirma que certo prazer poderia ser o bem supremo (1153b7-24) e o segundo que o prazer é, em certo sentido, o bem supremo (1153b25-32). O primeiro pode ser resumido no que se segue: mesmo havendo prazeres ruins, nada impede a possibilidade (ouden kôluei: 1153b7) 27 $^{27}$ que um certo prazer seja o bem supremo. Do mesmo modo, o fato de haver certos conhecimentos ruins não impede que um possa ser o melhor dentre todos. Visto que nada impede tal possibilidade, a conclusão é obtida a partir de duas premissas verdadeiras, a saber:

1. visto que cada disposição (hexis) exerce suas atividades sem impedimentos e a felicidade é uma atividade desimpedida de todas ou de uma disposição, a saber, a mais desejável; e

2. como toda atividade desimpedida é prazerosa $;{ }^{28} \operatorname{logo}$,

3. o bem supremo seria um certo prazer (eiê an tis hêdonê to ariston).

A conclusão de que um tipo de prazer seria o bem supremo levou diversos comentadores a procurarem uma solução para o dilema posto, a ponto de Christof Rapp,${ }^{29}$ fazendo um balanço das muitas e díspares interpretações, denominar tal tese de chocante - "the shoching thesis". A nossa interpretação, por sua vez, concorda com a de Aspásio, ${ }^{30}$ pois entendemos tal argumento como sendo exclusivamente dialético. Aspásio, em seu comentário à Ética Nicomaqueia (150.31-152.3), diz que, se o primeiro Tratado for de fato de Aristóteles, o argumento é dialético, ad hominem $(151.21,26)$ e, possivelmente, ad personam Speusippi. A nosso ver, porém, o argumento é dialético refutativo por ter como alvo a opinião de um adversário e não o próprio adversário. Não seria contra a pessoa de Espeusipo ou contra a pessoa de Platão, mas contra a concepção

27 "ouden kôluei" parece indicar a possibilidade lógica da conclusão se seguir, como bem assinalou Rapp (2005, p. 215).

28 Para compreender tal estratégia argumentativa é importante ter em mente que o prazer acabou de ser definido como uma atividade desimpedida (1153a14-15).

29 RAPP, 2005, p. 218-220.

30 ASPÁSIO, 2006, p 18-24, 150. 
anti-hedonista que ambos sustentam; mais especificamente, contra a opinião de que nenhum prazer, mesmo que todos sejam bons, poderia ser o bem supremo.

Isso significa que a afirmação de que certo prazer seria o bem supremo tem um efeito meramente refutativo, portanto, dialético. Certamente, Aristóteles não pretenderia se contradizer assumindo tal tese. Há algumas indicações linguísticas que apontam para esta interpretação, como o uso da forma verbal seria (eiê an: 1153b13) que atenua a atribuição do predicado (certo prazer: tis hêdonê) ao sujeito (bem supremo: to ariston) e do advérbio em certo sentido (pôs) contido na seguinte frase presente mais adiante no texto: "Que todos os animais e todos os seres humanos perseguem o prazer é um sinal de que ele, em certo sentido (pôs), é o bem supremo" (1153b25-28).

Outros comentadores, como Owen ${ }^{31}$ e Charles, ${ }^{32}$ pretendem solucionar tal dilema negando que o filósofo tenha definido o prazer como uma atividade. Owen, por exemplo, diz que o objeto do Tratado não é a atividade prazerosa, mas as coisas prazerosas; ou seja, não é o prazer, mas o prazeroso que deve ser entendido como uma atividade, pois são as atividades desimpedidas que nos dão prazer. Com essa interpretação, de fato, a contradição desapareceria, pois a felicidade é realmente uma atividade desimpedida que nos dá prazer, isto é, a felicidade não seria o prazer, mas o objeto de prazer. Afinal, a vida feliz "é prazerosa em si mesma” (EN I 8: 1099a10-16). Certamente, dizer que a felicidade é prazerosa é bem distinto de dizer que ela é um tipo de prazer.

O problema é que Aristóteles, a meu ver, não está preocupado em definir simplesmente o objeto prazeroso, mas sim o próprio prazer. E este nada mais é do que as atividades prazerosas, isto é, as atividades ou atualizações de nossas capacidades anímicas e físicas, havendo ou não objeto externo que cause prazer. Com efeito, como a investigação do primeiro Tratado tem como objetivo apreender a natureza do prazer de modo a garantir que ela possa ser um bem, acreditamos que Aristóteles não esteja simplesmente definido o objeto prazeroso. Mesmo porque o valor moral do prazer não se reduz à natureza do seu objeto, visto que podemos ter bons objetos, mas desejá-los excessivamente, o que torna o prazer ruim. 
Charles, por sua vez, diz que o termo atividade (energeia) é ambíguo e pode querer dizer tanto o exercício como o resultado da atividade, sendo que o prazer deve ser entendido antes como resultado do que como o próprio exercício da atividade. Ora, a ambiguidade de um termo não poderia por si só sustentar uma interpretação ou refutar a sua contrária, mesmo que ela dê certos indícios a favor de uma e não de outra. A concepção de prazer como resultado da atividade, a meu ver, só foi formulada no segundo Tratado, não podendo, portanto, ser apropriada para a definição de prazer do primeiro Tratado.

Segundo Rapp, não há problema algum em identificar a felicidade com um tipo de prazer, visto que cada atividade tem o seu prazer próprio, como fica claro com a tese da diferença específica dos prazeres do livro X. Isso significa que tudo o que Aristóteles queria dizer é que um tipo de prazer é constitutivo da felicidade, mas não é a própria felicidade; pois há uma predicação extensional, mas não identitária entre os sujeitos: felicidade e prazer. O ponto problemático dessa intepretação é que, no primeiro Tratado, esta sofisticada condição de que o prazer é sempre uma atividade que acompanha outra não fora elaborada; logo, no primeiro Tratado, a predicação é sempre identitária com a atividade exercida, enquanto no segundo, é sempre extensional. Cabe fazer a ressalva que a identidade é apenas hipotética e não real. Podemos, inclusive, especular que tal condição foi elaborada no segundo Tratado justamente para dar conta desta armadilha que o filósofo coloca a si mesmo neste momento. Ademais, a pergunta que fica pendente, já que Rapp não responde, é a de saber qual é este tipo de prazer. Tomás de Aquino, como veremos, responde à nossa pergunta sem hesitação: tal prazer só pode ser o contemplativo.

Visto que algum prazer poderia até ser considerado o bem supremo, Aristóteles nos diz em seguida que, nesse sentido, nós podemos compreender por que todos "incluem o prazer na felicidade": "é por essa razão que todos pensam que a vida feliz é prazerosa e incluem o prazer na felicidade, e com boas razões, já que nenhuma atividade impedida é perfeita, e a felicidade é perfeita” (EN VII 13: 1153b14-17). Essa opinião geralmente aceita e já referida em outras passagens da Ética Nicomaqueia ${ }^{33}$ não postula a identificação da felicidade a um tipo de prazer, pois o que todos pensam é que a vida feliz é prazerosa (hêdun) e não que ela seja um tipo de prazer (tina hêdonên). Por isso, com boas razões, todos 
incluem (emplekousi) o prazer na vida feliz. Certamente, Aristóteles concorda com a inclusão do prazer na vida feliz, pois, para ele, a vida feliz é em si mesma prazerosa. Vejamos, em seguida, como e por que tal inclusão é necessária segundo o filósofo.

A razão pela qual a vida feliz é necessariamente prazerosa é que ela é uma atividade perfeita (teleios), portanto, desimpedida; e toda atividade desimpedida é prazerosa. Ou seja, como a felicidade é perfeita, a sua realização não poderia ser impedida pela falta de certos bens externos, pois um impedimento à sua realização implicaria a sua imperfeição. Afirmar que é preciso exercer de modo desimpedido a felicidade corrobora com a tese que nega a possibilidade de a disposição virtuosa ser, sob quaisquer circunstâncias, a causa suficiente da felicidade. Ora, mesmo o virtuoso certamente depende de bens externos para viver bem. A falta desses bens pode se constituir como fator impedidor à realização da atividade perfeita. Os fatores impedidores que são extrínsecos à disposição e ao desejo do agente virtuoso podem ser entendidos, segundo o filósofo, como as adversidades corporais e materiais. Um exemplo extremo que costuma nos fornecer o filósofo é que não seria feliz aquele que, mesmo sendo bom, sofresse grandes e intensas vicissitudes. Porém, não estando em falta os bens do corpo e os da fortuna, a atividade é exercida desimpedidamente.

Ademais, com relação à boa fortuna (eutuchia), podemos compreender como sendo tanto bens externos materiais, como a riqueza, o poder político, os amigos e os filhos, como também a boa sorte, pois é matéria de sorte (tuchê) ser herdeiro de riquezas, ter boa estirpe, beleza etc. ${ }^{34} \mathrm{O}$ filósofo ressalta que, apesar de a boa fortuna ser necessária para a felicidade, não se poderia identificá-la com a felicidade, mas antes a primeira deve ser definida em relação à segunda. Tanto a ausência como o excesso de fortuna, conclui Aristóteles, são impedidores da felicidade. Isso significa que a fortuna moderada é necessária, mas, quando excessiva, pode atrapalhar por induzir aquele que a possui em excesso à insensatez e arrogância. ${ }^{35}$

34 Cf. EN I 8: 1099a29-b8. Ver também Ret. II 12: 1389a1. Em Retórica I 5, boa fortuna consiste em "obter e manter as boas coisas, cuja causa é a sorte (tuchê), senão todas, a maioria ou as mais importantes" (1361b39-1362a1).

35 Parece ser evidente que a ausência de fortuna ou sorte (tuchê) impede a realização das atividades desimpedidas, portanto, da própria felicidade (eudaimonia), como vemos em EN I 9 (1099b9-1100a9). Quanto ao excesso de fortuna, poderíamos supor que ele possa ser prejudicial se nos induzir à negligenciar a aquisição e a preservação da virtude. Agora, se de fato ela seria prejudicial 
Em seguida, Aristóteles fornece seu segundo argumento quanto à possibilidade de um prazer ser o bem supremo (1153b25-32). O argumento, à primeira vista, parece ser dialético, entendendo dialético como um argumento que assume a opinião da maioria ou dos mais sábios como um objeto a ser examinado, pois que ele guardaria algo de verdadeiro. $\mathrm{O}$ argumento se justifica a partir da tese de que aquilo com o qual todos concordam não pode ser inteiramente falso, a saber: "Que todos os animais e todos os seres humanos perseguem o prazer é um sinal de que ele é, em certo sentido (pôs), o bem supremo” (EN VII 13: 1153b25-28). Trata-se de um consenso, como parece indicar a citação de Hesíodo que o filósofo estagirita utiliza para mostrar que há algo de verdadeiro no argumento, a saber: "a voz de muitos não é inteiramente insignificante" (Trabalhos e Dias: 173). A passagem análoga a esta, presente no livro X, cujo objetivo é refutar o anti-hedonismo de Espeusipo, parece ser ainda mais explicativa:

Aqueles que negam que aquilo que todos buscam (ephietai) seja um bem, certamente falam coisas sem sentido. Isso porque dizemos que aquilo que todos pensam assim é. E aquele que se contrapõe a esta crença, dificilmente nos persuadirá de sua própria crença. Se apenas seres irracionais desejassem obter o que é prazeroso, haveria algum sentido no que dizem; mas na medida em que seres inteligentes também o fazem, que sentido teria tal objeção? Talvez até mesmo animais inferiores possuam algo natural mais forte do que eles mesmos que busca o seu bem próprio (ephietai toû oikeiouagathoû) (EN X 2: 1172b36-1173a5).

não é claro e o filósofo não desenvolve essa questão. Todavia, é razoável supor que aquela pessoa que não passasse por nenhuma adversidade não poderia desenvolver certas disposições necessárias para ser um homem bom e, consequentemente, feliz. É possível que o excesso de riqueza o impeça de saber lidar com as dores adequadamente, na medida em que não lança o agente em circunstâncias desfavoráveis que lhe obriguem a enfrentar certas dores em vista de agir virtuosamente. Em Ret. II 17: 1391a33-b1, o filósofo sinaliza tal dificuldade ao nos dizer que a maior parte daqueles que usufruem de boa fortuna é arrogante e insensata. Para o filósofo, o ideal é ter moderada fortuna: "Ainda que não se possa ser feliz sem bens exteriores, não devemos pensar que aquele que há de ser feliz precisará de muitas e grandes coisas; pois a autossuficiência e a ação moral não requerem tais bens em excesso. É possível realizar boas ações sem ter de dominar a terra e o mar. Com efeito, mesmo com recursos moderados, alguém pode agir virtuosamente (isso é manifesto, considerando-se que simples indivíduos levam a cabo ações valiosas tanto quanto os poderosos, ou até mais); basta dispor de bens exteriores nesta medida, pois será feliz a vida que atue de acordo com a virtude. Sólon também, provavelmente, compreendeu bem o homem feliz ao descrevê-lo, segundo o que pensava, como aquele que, moderadamente provido de bens exteriores, havia praticado as mais belas ações e vivido de modo temperante; porque se pode, com bens moderados, praticar o que se deve" (EN X 8: 1179a1-12). 
Neste momento, no livro X, em que o mesmo argumento é usado para refutar o anti-hedonismo, ele não parece ser mais de cunho dialético, mas sim científico. Ou seja, a expressão de que todos os seres buscam o prazer não parece ser fruto apenas de um consenso, mas antes da observação do comportamento dos animais irracionais e racionais. Isso porque a busca de prazer se traduz pela busca natural do bem próprio e isso é comum a todos os seres por causa de um princípio interno natural que os impele a buscar o seu bem próprio. Tal princípio, que Aristóteles chama de divino no livro VII (1153b32), é o mesmo referido no livro $\mathrm{X}$, como vimos na citação acima: "até mesmo animais inferiores possuem algo natural mais forte do que eles mesmos, que busca o seu bem próprio". Certamente, o bem para cada ser varia conforme sua natureza, mas há algo em comum para todos os homens e animais, a saber: todos buscam o prazer na medida em que buscam o seu bem próprio. Seria contra intuitivo afirmar que aquilo a que todos buscam seja um mal para si, pois, se a natureza faz com que todos os animais persigam o prazer, então não poderíamos dizer que a natureza erra por inteiro ou na maior parte dos casos. Assim, a explicação do argumento parece ser antes de cunho biológico ou naturalista no livro $\mathrm{X}$ do que dialético, quando aparece no livro VII. Se todos os animais buscam o prazer, parece ser mais do que legítimo afirmar que o prazer possa ser necessariamente um bem, ou até mesmo o bem supremo em algum sentido.

Este segundo argumento seria decisivo para atribuir ao prazer o estatuto de bem supremo, se não fosse pela expressão adverbial "em certo sentido" (pôs: 1153b27), que atenua a afirmação identitária. É possível conceber dois sentidos para o advérbio pôs: um material e outro formal. Segundo a interpretação material do advérbio, nem todo prazer, mas somente um tipo seria o bem supremo, ou seja, "certo prazer é o bem supremo”. Como inferiu Tomás de Aquino, esse tipo de prazer só poderia ser o contemplativo. Segundo a interpretação formal, o prazer não é absolutamente o bem supremo, mas apenas em certo sentido, isto é, conforme certa inferência hipotética, a saber: se o prazer é uma atividade desimpedida, assim como a felicidade, isso significa que o prazer seria, enquanto atividade desimpedida, identificável à felicidade. Ou seja, o prazer seria um atributo próprio à natureza da felicidade e não a sua própria natureza, visto que esta não é a definição de felicidade. Isso indica que a atenuação não seja gratuita, e, mais ainda, que a interpretação formal do advérbio seja mais razoável, na medida em que a felicidade não é concebida como um tipo de prazer, isto é, como um tipo de atividade desimpedida do nosso estado natural, mas antes como uma 
atividade segundo perfeita virtude que também possui o atributo de ser desimpedida, portanto prazerosa.

Com efeito, o atributo ser desimpedida e, consequentemente, prazerosa, por sua vez, não expressa a definição de felicidade, mas é antes uma propriedade que decorre de sua definição. Ou seja, é por ela ser uma atividade segundo perfeita virtude que ela é uma atividade desimpedida e prazerosa. O prazer é antes o efeito e não a causa do desimpedimento. Por isso, assim como interpreta Alexandre de Afrodisia, a felicidade é prazerosa porque ela é realizada conforme a virtude. Ser prazerosa é uma decorrência necessária de sua essência, é um atributo próprio da felicidade, mas não a define enquanto tal.

Segundo Alexandre de Afrodisia, não é o prazer, mas a virtude a principal causa de certa atividade ser desimpedida, pois viver conforme a virtude tem como consequência a ausência de certos impedimentos, pelo menos os impedimentos oriundos da disposição e do comportamento moral do agente. Como a vida feliz é aquela vivida segundo a virtude e não segundo o prazer, a virtude é, em grande parte, a causa de o homem realizar as atividades próprias à sua natureza e de realizá-las de modo desimpedido, visto que o vício ou a falta de regramento quanto aos próprios desejos e emoções impediriam a fruição de uma vida feliz. ${ }^{36}$

Digo em grande parte, uma vez que a boa fortuna (eutuchê) também contribuirá para a livre fruição da felicidade. Há, como podemos notar, dois tipos de impedimento: um intrínseco à própria disposição moral do agente, isto é, se o mesmo é virtuoso ou não, pois está no poder do agente vir a ser ou deixar de ser virtuoso conforme as ações que pratica, e outro extrínseco ao agente, pois não está ou está parcialmente no poder do mesmo ter ou não ter boa fortuna. Se a boa fortuna deve ser entendida como bens do corpo, bens materiais e sorte, então, digamos que os bens do corpo estão parcialmente sob o poder do agente, uma vez que o mesmo pode se cuidar para manter a boa saúde física, mas também pode ocorrer o azar de ele contrair ou sofrer alguma doença imprevisível. Do mesmo modo, os bens materiais estão parcialmente no poder do agente, visto que é preciso trabalhar ou exercer alguma atividade remunerada para obtê-los, mas nem toda sociedade fornece oportunidade de trabalho igualmente para todos os seus membros. Quanto mais desigual for a sociedade, menos 
estará no poder do agente conquistar seus próprios bens materiais. Quanto à sorte, por sua natureza absolutamente contingente, o agente não tem poder algum sobre ela. É preciso, bem sabemos, contar com certa dose de boa fortuna para que não haja impedimento do bem viver.

Contrariamente ao que foi dito, Tomás de Aquino supõe que a identidade entre prazer e bem supremo se explica se interpretarmos que Aristóteles estaria se referindo a um tipo determinado de prazer e não a qualquer um que seja. Tomás entende que, a partir da frase - "talvez eles não persigam o prazer que eles pensam e dizem que perseguem, embora persigam o mesmo prazer (tên autên)" (1153b30-1) -, poder-se-ia concluir que todos, por natureza, buscam o mesmo prazer; ainda que, por ignorância ou julgamento incorreto, pensem e digam que buscam outros prazeres. Isso porque, segundo Aquinate, a natureza nos colocou algo de divino, isto é, uma inclinação natural em desejar conhecer. Desse modo, todos estão inclinados por natureza a desejar o mesmo prazer enquanto o mais supremo, a saber, o prazer da contemplação. ${ }^{37} \mathrm{O}$ erro consiste em supor, como faz a maioria, que o prazer corporal é o bem supremo. Certamente, tal suposição se deve ao fato de ele ser o tipo de prazer mais compartilhado por todos, mais perceptível e conhecido, na medida em que envolve coisas necessárias da vida.

Há dois problemas evidentes na interpretação de Tomás de Aquino. O primeiro é que Aristóteles parece estar se referindo ao prazer que todos, incluindo os animais irracionais, perseguem (1153b26). Como os animais não são capazes de contemplar, o prazer contemplativo não poderia ser aquele que todos os seres buscam. O segundo problema é que a frase é ambígua, pois não sabemos ao que se refere o mesmo prazer (tên autên) que todos perseguem. Certamente, trata-se do mesmo tipo de prazer, mas não que este seja necessariamente o contemplativo, como interpretou o Aquinate.

O tipo de prazer que seria o mesmo para todos, a meu ver, é justamente aquele que é bom em absoluto (haplôs) ou por natureza (phusei). É justamente aquele que todo animal sente ao realizar o seu bem próprio. O bem próprio varia conforme cada espécie, mas o prazer que lhe acompanha é essencialmente o

37 A interpretação de Tomás de Aquino (1993, § 1511) poderia ser reforçada se fosse assumidamente uma tese aristotélica a de que a vida feliz é a vida contemplativa. Não examinaremos em detalhe esse ponto, mesmo assim, gostaríamos apenas de ressalvar que, em EN X 7, não se afirma a identidade entre o prazer contemplativo e a felicidade, mas entre a atividade contemplativa e um tipo de felicidade, a saber, a mais perfeita. Logo, a identidade se produz entre a atividade contemplativa e a felicidade perfeita, e não entre o prazer da atividade contemplativa e a felicidade em geral. 
mesmo, a saber: um prazer natural, isto é, uma atividade desimpedida conforme a natureza de cada ser. Ademais, se o prazer contemplativo fosse o bem supremo, Aristóteles não poderia ter afirmado linhas acima que até mesmo a contemplação (theôrein) pode ser nociva se excessiva (1153a19-21).

Por fim, depois de ter formulado a hipótese de que certo prazer poderia até ser o bem supremo, Aristóteles conclui o capítulo demonstrando, mais uma vez, que o prazer é um bem, visto que a negação desta concepção produz inconsistências (1154a1-7). Assim, por via negativa, chega-se à conclusão de que a vida feliz é necessariamente prazerosa. $\mathrm{O}$ argumento se sustenta a partir da refutação de três inconsistências. A primeira delas é a seguinte: (i) se o prazer, ou seja, a atividade prazerosa, não for um bem, então (ii) o homem feliz não viverá prazerosamente, o que é incongruente. A segunda mostra que (i) se o prazer não fosse bom, tampouco ele seria necessário ao homem feliz; porém, (ii) como o prazer é necessário à felicidade, então ele deve ser um bem. A terceira refutação consiste em dizer que (i) se o prazer não fosse nem bom, nem mau, (ii) também a dor, sendo o seu contrário, não seria nem boa, nem má, e não teria porque evitá-la; logo, (iii) a vida do homem feliz poderia ser penosa, ou não seria mais prazerosa do que a dos outros homens, o que é evidentemente falso. Desse modo, o Estagirita conclui o capítulo 13 com a tese de que o prazer pode necessariamente ser um bem, caso contrário, a vida virtuosa não seria em si mesma prazerosa e poderia ser evitada como se fosse penosa.

Depois do exame sobre o prazer em geral, Aristóteles, no capítulo 14, continua a empreitada para provar não mais que a sua natureza em geral pode ser boa - isso ele já fez no capítulo precedente -, mas que a do prazer corporal pode ser boa. A prova se faz por meio da refutação da opinião certamente platônica ${ }^{38}$ que diz que alguns prazeres podem ser bons - os belos (kalai) e desejáveis (hairetai) -, embora a maioria dos prazeres, que são os corporais, seja ruim. O intuito do capítulo é mostrar que eles não são ruins neles mesmos, mas que podem se tornar ruins se desejados em excesso.

$\mathrm{O}$ argumento inicial para refutar tal opinião anti-hedonista não é em nada sofisticado (1154a8-21). Vejamos: se o prazer corporal fosse ruim, a dor, que lhe é oposta, seria boa. Como não é verdade que a dor seja boa, o seu oposto é o que é bom, ou seja, o prazer; logo, o prazer corporal também pode ser bom. A 
explicação de que o prazer é bom simplesmente por ser oposto à dor não parece ser tão persuasiva. Se fosse assim, todo prazer seria bom e toda dor ruim, o que não é o caso.

Porém, adiante, acresce o filósofo que, se o prazer corporal é necessário, de duas uma: "ou os prazeres necessários são bons no sentido de que o que não é ruim é bom; ou eles são bons até certo ponto” (1154a13-14). O refinamento da argumentação aparece quando o filósofo opta pela segunda alternativa em detrimento da primeira e nos fornece as condições pelas quais o prazer corporal pode ser "até certo ponto (mechri)" bom ou ruim. Com efeito, como o prazer corporal é aquele que sentimos quando suprimos nossas necessidades físicas, ele não poderia ser ruim em si mesmo, mas seu excesso sim.

A explicação consiste em dizer que, do mesmo modo em que há disposições (hexeis) e movimentos (kinêseis) que não comportam excesso, como a disposição virtuosa, tampouco os seus respectivos prazeres poderiam ser excessivos. Por outro lado, há também aquelas que são excessivas, como a disposição intemperante, cujo prazer também será excessivo. Em suma, o prazer, a depender da disposição a qual ele esteja vinculado, poderá ser ou não excessivo. ${ }^{39}$ Se for assim, conclui o filósofo:

É possível haver excesso nos bens corporais, e o homem vil é vil por persegui os excessivos e não os necessários; pois todos se deleitam de algum modo com comidas saborosas, vinhos e prazeres sexuais, mas nem todos como se deve (hôs dei) (EN VII 13: 1154a16-19).

Isso significa que o prazer corporal é necessário e bom quando não excessivo e que o modo excessivo de senti-lo o torna ruim não em si mesmo, mas relativamente a quem assim o sente. Há, neste caso, não um desvio no objeto, mas no modo de buscá-lo. Uma coisa é ter prazer com o que não se deve, com objetos indevidos; outra coisa é ter prazer como não se deve, isto é, excessivamente. ${ }^{40}$ Aristóteles, portanto, quer mostrar que de fato há objetos corporalmente prazerosos que são necessários, mas que podem promover uma sensação prazerosa

39 Vemos aqui o que poderíamos chamar de um prenúncio da tese, elaborada no segundo Tratado, em que a natureza moral do prazer é determinada pela atividade que ele acompanha. No caso, não será mais a disposição virtuosa, mas sim a atividade virtuosa oriunda da disposição correspondente que o bom prazer acompanhará.

40 Sobre esse ponto ver EN VII 4 e III 11. 
ruim. A comida, a bebida e o sexo são tais tipos de objetos que, se desejados excessivamente, tornam o prazer nocivo. Até mesmo a contemplação pode ser nociva se excessiva, mas isso não significa que ela passe a ser em si mesma ou em absoluto ruim. ${ }^{41}$

A pergunta que o filósofo estagirita se coloca agora é a seguinte: se os prazeres corporais excessivos, próprios do intemperante, são ruins, o seu contrário, a dor, deveria ser boa? Para o temperante, a ausência de prazeres excessivos não é dolorosa, mas para o intemperante sim. Este persegue o prazer excessivamente e evita não apenas a dor excessiva, mas qualquer dor. Como a ausência de prazer é penosa para o intemperante, ele procura suprir tal ausência ou falta dolorosa perseguindo incessantemente o prazer. É desse modo que ele se torna escravo da sua necessidade de ter prazer. Isso significa que nem toda dor deve ser considerada ruim simplesmente por ser oposta ao prazer; talvez, inclusive, seja preciso sentir a dor da falta de prazer quando este é impróprio ou é desejado excessivamente. Assim, se nem todo prazer é bom, tampouco toda dor seria ruim em termos absolutos (haplôs).

Em seguida (1154a22-b21), Aristóteles pretende demonstrar por que os prazeres do corpo são reputados como os mais desejáveis para muitos, embora, como já foi dito no início do capítulo, eles não possam ser considerados bons em absoluto, mas apenas em certo sentido. A argumentação é estrategicamente persuasiva, pois consiste em mostrar que as causas desta reputação se aplicam para alguns casos, mas não podem ser tomadas como verdadeira sem absoluto (1154a24). Ou seja, não é verdade que o prazer corporal seja o mais desejável dentre os prazeres, mas é verdade que assim ocorra em alguns casos. Isso não significa que ele seja ruim e tenha que ser recusado por ser o mais desejável para algumas pessoas, a não ser que ele seja prejudicial. Mais uma vez, tudo o que Aristóteles pretende é refutar a opinião que nega a possibilidade de o prazer corporal ser bom. Para o filósofo, como veremos, o prazer corporal pode ser dito um bem quando ele não for excessivo e prejudicial (blaberai).

As razões pelas quais os prazeres corporais parecem ser os mais desejáveis são duas. A primeira delas é que eles expulsam a dor (1154a26-b1). Em geral, os prazeres corporais servem como remédios restauradores (iatreiai) de um estado débil ou em falta. A segunda é a sua intensidade. Com efeito, para a dor intensa,

41 Ver EN VII 12: 1153a18-21. Ao contrário do que diz Tomás de Aquino (1993, § 1519), pois, para ele, a contemplação, por ser um bem em si mesmo, não admitiria excesso. 
o prazer corporal intenso (sphodrai) é buscado como se fosse uma droga para aliviar a dor. Justamente por isso, a tendência é que ele seja buscado excessivamente e, se assim o for, ele se tornará um prazer ruim.

Tais características atribuídas ao prazer corporal justificam a opinião sustentada por Platão e Espeusipo de que este tipo de prazer seria em si mesmo ruim. Porém, devemos fazer jus aos matizes propostos por Aristóteles compreendendo que, apesar de alguns prazeres corporais serem considerados ruins e outros prazerosos apenas acidentalmente, ainda assim é possível haver aqueles que sejam bons, e que, portanto, a natureza do prazer corporal não poderia ser considerada absolutamente (haplôs) ruim.

Os prazeres absolutamente ruins são próprios daquelas ações de uma natureza vil (phaulês phuseôs). Já aqueles que são usados como remédios para restaurarem um estado debilitado são acidentalmente prazerosos. Podemos dizer que, no primeiro caso, o intemperante busca o prazer pelo prazer; enquanto que, no segundo caso, o convalescente busca o prazer não por ele mesmo, mas para compensar uma dor. Um deve ser dito moralmente condenável, e o outro pode ser dito acidentalmente bom. ${ }^{42}$

Neste momento, Aristóteles retoma a distinção entre prazer natural e prazer acidental feita em EN VII 12, sobretudo em 1152 b34. O prazer que acompanha um processo de retorno ao estado natural, portanto, de aperfeiçoamento (teleoumenôn) (1154b2), ${ }^{43}$ pode ser, enquanto acompanhante, considerado acidentalmente bom. Ele não pode ser dito bom por natureza, pois ele não é próprio a um estado natural que em nada carece. Tampouco ele seria necessariamente ruim por acompanhar tal restauração. Todavia, ele pode ser considerado bom apenas por acidente, já que ele é dito prazeroso não nele mesmo, mas por acompanhar um retorno ao nosso perfeito estado de natureza. Diferentemente, o prazer natural é dito prazeroso nele mesmo, pois é próprio da atividade de nosso estado natural preservado ou da parte que permaneceu saudável.

42 Como a característica essencial do prazer indevido é a de ser excessivo e a do prazer acidental é a de ser um compensador da dor ou restaurador da saúde, Aubry (2005, p. 242) os distingue em duas classes: o primeiro seria excessivo e perverso, na medida em que é buscado por alguém vil segundo a lógica do máximo prazer e o mínimo de dor; enquanto o segundo seria apenas patológico, na medida em que é buscado por alguém doente ou debilitado segundo a lógica da compensação ou alívio da dor excessiva.

43 O mesmo termo é atribuído para a definição do processo acompanhado de prazer acidental em 1153a10-14. 
Isso explica que o processo de convalescença seja sentido como prazeroso, porém, ele é apenas acidentalmente prazeroso, e tal prazer é apenas acidentalmente bom (1154b2); visto que é a atividade da parte saudável que é naturalmente prazerosa. Como define o filósofo mais adiante:

Os prazeres sem dor não admitem excesso. E tais prazeres são por natureza e não por acidente. Chamo de prazeres por acidente aqueles que são restauradores (ta iatreuonta). Isso porque o ato de restaurar ocorre por meio da ação do que permaneceu saudável; por isso <o processo> parece ser prazeroso. Assim, o prazer por natureza é aquele que produz uma ação de uma natureza <saudável> (1154b16-21).

Além da distinção entre prazer natural e acidental, Aristóteles nos fornece outra distinção, a saber, aquela entre prazer natural (hêdea phusei) e, o que poderíamos chamar de prazer "antinatural" ${ }^{4}$. O prazer natural não envolve dor (1154b15), pois não é excessivo, o que é evidente se tomarmos como exemplo a ação virtuosa. Tal ação é prazerosa por natureza, portanto, não envolve dor psíquica, embora possa envolver dor física, como é tipicamente o caso da ação corajosa. Como diz o filósofo, "a ação segundo a virtude é prazerosa ou sem dor - certamente não é penosa” (EN IV 1: 1120a26-7). Já o prazer “antinatural” ou contrário à natureza envolve dor. A dor aqui referida é o sofrimento causado pela ausência ou falta do prazer, visto que não ter prazer é doloroso para quem o busca excessivamente (1154a20-21). É patente que, neste momento, Aristóteles usa o mesmo critério que Platão para distinguir o prazer bom e puro, isto é, não misturado com a dor, do prazer falso e impuro, isto é, misturado com a dor. ${ }^{45}$

Em poucas linhas, podemos dizer que o prazer natural é conforme o estado perfeito de natureza, que pode ser entendido como um estado de saúde, enquanto o prazer antinatural é contrário a tal estado e se constitui como espécie de doença moral. Já o acidental é concomitante ao estado de debilidade da saúde, portanto, de doença física ou psíquica.

Também em EN VII 4: 1148a22-b5, o Estagirita estabelece a distinção entre prazer por natureza (phusei haireta), contrário à natureza (enantia) e intermediário

44 Além do prazer excessivo, próprio da disposição intemperante ou acrática, o prazer bestial também é considerado antinatural; porém, o primeiro se encontra no campo moral, enquanto o segundo o extrapola. Sobre o prazer bestial, ver EN VII 5: 1148b15-20.

45 Cf. Filebo 36c-53c. 
ou neutro (metaxu). Aqueles que são desejados (haireta) por natureza, e não de modo excessivo, são belos e bons, como "a vitória, a honra, a riqueza e outras coisas prazerosas do mesmo tipo” (1147b30). Os neutros são os prazeres necessários corporais que, em si mesmos, não são nem bons nem ruins, mas, se desejados excessivamente, tornam-se ruins, e, moderadamente, tornam-se bons. Já os contrários à natureza são todos aqueles cuja fonte é ruim e/ou o modo de desejar é excessivo, portanto, são contrários à razão (para ton logon). Por isso, o critério que determina a qualidade moral do prazer, além do seu objeto ser correto, é a forma moderada de desejá-lo. Assim, o prazer corporal, quando incide sobre um bom objeto e é fruído moderadamente, é naturalmente prazeroso.

Isso significa que o prazer corporal não precisa estar reduzido ao estatuto de ser acidentalmente prazeroso, como se fosse somente um compensador da dor; nem poderia ser inteiramente ou em todos os casos eticamente reprovável, como se fosse somente um tipo de prazer desejado pelo intemperante (akolastos) ou descontrolado (acrático). ${ }^{46}$ Ele pode ser, segundo Aristóteles, um bem, se o seu objeto e o modo de desejá-lo forem bons, isto é, se forem conforme a disposição temperante.

Além de sua característica de compensar ou aliviar a dor, a segunda razão pela qual o prazer corporal parece ser o mais desejável é a de que ele é perseguido devido a sua intensidade (sphodrai) por algumas pessoas que são incapazes de desfrutar de outros tipos de prazeres (1154b3-16). Conforme nos diz o filósofo, embora a necessidade de se ter prazer intenso seja causada pela dor de certas condições fisiológicas específicas de algumas pessoas, se tal prazer não for excessivo e prejudicial, não seria problemático desejá-lo (1154b4-5).

Ele nos fornece alguns casos que exemplificam essa situação de necessidade fisiológica em que o prazer corporal é usado como um supressor da dor. Em primeiro lugar, ele nos diz que muitos, por certa constituição física, não têm outra fonte de prazer, senão o corporal. Há pessoas, por exemplo, em que o estado de neutralidade de sua natureza é penoso, pois, segundo os fisiólogos, ${ }^{47}$ os movi-

46 Que o acrático busca prazeres corporais excessivos sem ter escolhido deliberadamente, ver EN VII 4: 1148a6-7; quanto ao intemperante buscar tais tipos de prazer deliberadamente, ver VII 7: 1150a1920 e 12: 1153a33-4.

47 Dos fisiólogos (phusiologoi) a que se refere Aristóteles, pelo menos um é reconhecidamente Anaxágoras, que diz que "toda sensação é acompanhada de dor (meta lupês)" (frag. A 92); ao contrário do que pensa o Estagirita, que diz que "para toda sensação há um prazer correspondente" (ENX 4: 1174b20-1). 
mentos e as atividades sensíveis, como os atos de ver e ouvir exigem um esforço penoso e contínuo que precisa ser compensado com prazeres corporais intensos. Os jovens, por sua vez, vivem em uma espécie de estado de intoxicação, como uma embriaguez, pois a própria juventude é prazerosa (hêdu hê neotês), porém, por estarem em fase de crescimento e de alterações fisiológicas contínuas e dolorosas, eles necessitam sentir prazeres corporais intensos. ${ }^{48}$ Por fim, no caso do melancólico (melancholikos), por ele ter certa disposição natural que produz um constante estado de irritação e desejos sempre violentos, ele precisa dos prazeres corporais igualmente violentos ou intensos (sphodrai) que funcionem como atenuadores ou aplacadores da dor. Ou seja, não basta que o prazer seja restaurador, ele deve ser tão intenso quanto for a dor que o melancólico estiver sentindo. ${ }^{49}$ Nesses três casos, como as pessoas que se encontram nessas condições têm necessidade de sentir prazeres corporais intensos, há uma tendência para que elas se tornem intemperantes (akolastoi) e viciosas (phaûloi).

Como vimos, há prazeres corporais acidentais, excessivos e intensos, por um lado, e, por outro, os necessários e naturais. Os excessivos são ruins, portanto, contrários à natureza. Os acidentais são aqueles que acompanham um processo de restauração da natureza, e podem ser bons ou ruins apenas acidentalmente. Os intensos são aqueles que funcionam como um remédio (iatreias) que alivia a dor intensa de certos estados, como o estado melancólico. Tais prazeres intensos podem ser ruins se também forem excessivos e prejudiciais.

48 Também em Ret. II 12: 1389a3 e ss, Aristóteles descreve o jovem como aquele que prontamente dá vazão aos seus apetites e, dos prazeres corporais, o sexual é o que ele mais obedece e menos tem controle sobre. Isso porque o prazer afrodisíaco é dito, em Probl. XXX: 955a34, como aquele que alivia o excesso. A comparação entre a embriaguez e a juventude também é feita em Probl. XXX, pois o vinho aquece a região onde pensamos e temos esperança, tornando-nos eutímicos (palavra derivada dos termos eu, de bem, e timia de thumos, ânimo): "é por isto que todos têm o desejo de beber até a embriaguez, pois o vinho, excessivo, torna-nos, a todos, esperançosos, como a juventude aos meninos: pois, se a velhice é desesperançada, a juventude é, por sua vez, plena de esperança” (955a1-4) (Tradução de Elisabete Thamer).

49 O termo melancolia significa, literalmente, bílis negra, e, origina-se da composição de dois termos: melaina, que vem de melas (negra) e cholê (bílis). Em Probl. XXX, o desequilíbrio na constituição física do melancólico, tanto por enfermidade como por natureza, é explicado em termos fisiológicos como uma mistura da bílis negra quente e fria. Conforme cada mistura há um tipo específico de melancolia (954a1-b5). Cabe ressaltar que o fenômeno também é descrito como a alteração entre depressão e euforia, e, não como costumamos compreender, isto é, como um tipo de tristeza profunda (953a33). 
Diferentemente desses últimos, os prazeres corporais necessários, quando desejados moderadamente, são naturalmente bons.

Pelo que foi dito, vemos que os prazeres corporais não são, em absoluto, os mais desejáveis, mas assim parecem ser relativamente a algumas pessoas que se encontram em certas situações de debilidade de ordem fisiológica ou moral. Isso significa que são duas as justificativas para que os prazeres corporais não apenas parecem ser mais desejáveis, mas sejam de fato desejados acima dos outros: uma moral, como no caso do intemperante, que deseja o prazer excessivo em vista dele mesmo; e outra fisiológica, pois os jovens, os melancólicos, os adoentados e outros em estado de debilidade natural desejam tais prazeres não em vista deles mesmos, mas para aliviarem as suas dores. Por essas duas justificativas, podemos compreender por que o prazer corporal é o mais desejado para algumas pessoas, mas isso não implica que ele deva ser condenado e excluído da vida moral, como gostariam Platão e Espeusipo.

O último parágrafo (1154b22-32) parece ser um tanto digressivo, mas acrescenta dois pontos importantes para a análise do prazer. O primeiro ponto é que nossa natureza, por ser complexa, sempre buscará o prazer, visto que este nunca será uma atividade indefinidamente contínua, como não o é nenhuma atividade que realizamos. O segundo ponto é que o prazer é antes repouso do que movimento justamente por ser uma atividade e não um movimento e a natureza da atividade está mais próxima da natureza do repouso do que a do movimento.

A explicação desses dois pontos merece ser mais explorada. Em primeiro lugar, Aristóteles nos explica por que a constituição de nossa natureza nos leva a buscar incessantemente o prazer. A nossa natureza, por ser complexa e não simples como a divina, contém nela mesma a causa da mudança (metabolê) e, por causa desta "segunda natureza que nos faz perecer" (1154b22), nenhum prazer pode ser contínuo eternamente. Como estamos em constante transformação, também estão os prazeres que sentimos. Por essa razão, buscamos sempre ter prazer, já que nenhum prazer pode ser indefinidamente contínuo. Este segundo elemento natural ou esta segunda natureza pode ser entendida como sendo o nosso corpo ou nossa matéria, isto é, aquilo que em nós é potencialmente mutável e princípio de morte, mas que a natureza divina não possui.

Em Metafísica XII 6-7, o prazer humano e divino também são comparados. Enquanto nós nos deleitamos às vezes e por pouco tempo, deus (theos) sempre se deleita (1072b15-25). Segundo o filósofo, deus é o princípio motor imóvel de toda mudança. A sua natureza é pura atualidade ou puro ato (ousia energeia) 
(1071b20), visto que se estivesse em potência nada garantiria que ele viria se atualizar. Tal substância é imaterial, visto que eterna, pois toda materialidade é princípio de mudança de toda natureza. Sendo eterna, doutro modo o mundo também não seria eterno, certamente é imóvel ou imutável, portanto simples (1072a32). A sua atividade é o prazer, já que o seu prazer é a realização plena e contínua de si mesma, isto é, a sua própria atualização. É possível identificar o primeiro motor com o melhor tipo de vida e o melhor tipo de atividade: o puro pensamento. Deus pensa continua e eternamente, enquanto nós só o fazemos por um breve período de tempo (mikron chronon). Deste modo, a atividade contemplativa é a melhor e a mais prazerosa (1072b25). Também em Ética Nicomaqueia X, 7, a atividade do pensamento ou contemplativa é dita como sendo a mais contínua, mais do que qualquer outra atividade, "já que podemos contemplar mais continuamente do que podemos fazer qualquer outra coisa" (1177a21).

Como a natureza divina é imaterial, ela não comporta potência (dunamis) de mudança e corrupção; por isso, ela é imóvel e eterna (1071b5). A mudança em nós, por sua vez, é oriunda de alguma degeneração (ponêrian), pois “assim como o homem que muda é degenerado, também é degenerada a natureza que necessita mudar" (EN VII 14: 1154b30). Portanto, como não podemos exercer a mesma atividade continuamente, também não teremos o mesmo prazer indefinidamente. Exercemos variadas atividades e juntamente com essas sentimos variados e descontínuos prazeres.

Em segundo lugar, quando Aristóteles diz que o prazer consiste mais no repouso (êremia) do que no movimento (kinêsis), Festugière ${ }^{50}$ acredita que esta tese funcionaria como uma razão para mostrar porque o prazer corporal não é o mais desejável, uma vez que os prazeres da alma são um repouso ativo e os corporais são movimentos que permitem excesso. Todavia, não nos parece que essa interpretação seja completamente plausível, pois Aristóteles afirma ${ }^{51}$ que alguns prazeres da alma também permitem excesso, como amar ouvir e narrar estórias, passar dias contando fofocas ou mesmo contemplar em excesso.

A nosso ver, seguindo a ordem argumentativa do primeiro Tratado, a afirmação de que o prazer consiste mais no repouso se explica por sua natureza ser

50 FESTUGIERE, 1946.

51 Cf. EN III 10: 1117b34-1118a2. 
antes uma atividade (energeia) do que um movimento (kinêsis) ou processo (genesis), ${ }^{52}$ ou seja, o prazer consiste mais na atualização de uma potência anímica do que simplesmente no movimento que padece o corpo. Agora, como a nossa natureza é mutável, visto ser composta de matéria, não podemos sentir prazer continuamente. Se o prazer não pode ser contínuo para nós é por causa da constituição de nossa natureza e não da natureza do prazer.

Tendo em vista que o movimento é de natureza processual e inacabada, se a própria natureza do prazer fosse movimento, não poderíamos compreender como que um tipo de substância imóvel, a divina, teria sempre e continuamente prazer. Em suma, mesmo o parágrafo sendo difícil e passível de diversas conjecturas, a concepção de que o prazer é mais próprio ao repouso apenas reafirma que a sua natureza é uma atividade, cuja forma (eîdos) é acabada ou perfeita desde seu aparecimento, isto é, sua forma é plenamente atualizada desde sempre, portanto não tende para um fim outro que não seja a sua própria realização.

Como veremos adiante, em Metafísica IX, 6, 1048b18-35, o movimento é uma ação (praxis) que não é fim nela mesma, que necessariamente tende para um fim outro que não a sua própria realização, que é inacabada, imperfeita e limitada; já a atividade é uma ação que é fim nela mesma, que necessariamente tende a ser contínua, que é acabada, perfeita e ilimitada. A característica de não ter limite (peras) fornece à atividade a capacidade de ser indefinidamente contínua, ou seja, ao contrário do movimento cuja necessidade de terminar está inscrita em sua natureza (como o movimento de construir uma casa), a atividade não possui em si mesma qualquer necessidade de término (como a atividade de perceber e de pensar). Esta é exatamente a característica que possui o prazer, por ser ele uma atividade. Ele só não é contínuo indefinidamente porque não somos deuses, porque nossa natureza é também material e mutável. Essa concepção certamente reforça a refutação da definição platônica de prazer como sendo um processo sensível, definição esta cujo paradigma é o prazer corporal.

Podemos, resumidamente, concluir o seguinte da análise do primeiro Tratado. Em primeiro lugar, ele parece ser antes refutativo do que propositivo, ou seja, Aristóteles está antes preocupado em mostrar o quão inconsistentes são as opiniões anti-hedonistas, sobretudo as de Espeusipo e de Platão, que pouco se coloca afirmativamente no intuito de definir a natureza e a função moral do 
prazer. Quanto ao seu aspecto propositivo, os ganhos que podemos retirar são os que se seguem:

1. a definição de prazer como uma atividade desimpedida de nosso estado natural;

2. o prazer não é nem o bem supremo nem o mal em absoluto, mas certamente pode ser um bem;

3. os prazeres corporais não são intrinsecamente ruins, mas apenas quando excessivos, portanto eles podem ser bons sob certas condições; e

4. o critério que determina a qualidade moral do prazer, além de seu objeto ser correto, é o modo moderado de desejá-lo.

Ademais, ao criticar a visão anti-hedonista, Aristóteles, por um lado, concorda com Eudoxo de que tudo o que parece ser prazeroso também parece ser bom (phainomenon agathon), mas, por outro lado, como nem tudo o que parece ser bom é bom e como nem todo prazer é bom, ele discorda de que o prazer ou mesmo um tipo de prazer poderia ser o bem supremo. A felicidade é prazerosa por ser necessariamente uma atividade desimpedida, pois que a sua perfeição não admitiria qualquer impedimento, interno ou externo; portanto, ser prazerosa constitui um de seus atributos necessários, mas não poderia ser suficiente para esgotar a sua definição.

Por fim, a conclusão a que chegamos é a de que o prazer, embora não seja o bem supremo, é necessariamente um bem quando for a realização de uma atividade desimpedida de nosso estado natural. Desse modo, fica evidente que Aristóteles compreende que o prazer não deve ser considerado em si mesmo bom ou mau, mas como possivelmente um bem, a depender do caráter moral e do estado de natureza em que se encontra aquele que sente prazer. Distancia-se, com isso, de uma interpretação essencialista do valor moral do prazer, pois o bom prazer é determinado conforme a retitude racional e desiderativa de quem o sente, como será mais bem explicitado adiante.

\section{Análise do segundo Tratado do prazer}

O segundo Tratado inicia-se, assim como o primeiro, com a apresentação das razões para se estudar o prazer (1172a19-25), a saber: como o prazer nos é 
congênito e dura por toda a vida, e como todos escolhem (proairoûntai) o prazer e evitam (pheugousin) a dor, é preciso educar os jovens de modo que eles bem administrem a busca do prazer, pois gostar e desgostar do que se deve é fundamental para a formação do caráter virtuoso. Se as nossas ações e emoções são acompanhadas de prazer e dor, se o prazer é um fator motivador determinante de nossas ações, então ser educado para aprender a regular os próprios apetites e, consequentemente, ter prazer com o que é de fato bom é moralmente essencial. ${ }^{53}$

Similarmente ao primeiro Tratado, aqui também as opiniões divergentes sobre o prazer são elencadas, mas de modo resumido, expondo-se apenas a oposição entre o radicalismo hedonista de Eudoxo, para o qual o prazer é o bem (tagathon), e o anti-hedonismo de Espeusipo, para o qual o prazer é o mal (1172a26-34).

Quanto à opinião anti-hedonista, Aristóteles nos diz que uns a sustentavam porque de fato acreditavam nela; outros, mesmo não acreditando, assim a afirmavam, pois julgavam ser mais conveniente. Aqueles que não acreditavam, mas afirmavam que o prazer é um mal, têm como estratégia convencer a grande maioria naturalmente inclinada aos prazeres a se afastar deles. O intuito é conduzir os homens para o sentido contrário até que alcancem o meio termo ou a moderação com relação ao uso dos prazeres.

Essa estratégia, porém, mostra-se ineficiente, pois são ineficazes as palavras (logoi) quando estas não correspondem aos fatos (erga). Aqueles que dizem que o prazer é um mal e são flagrados buscando sentir prazer são imediatamente desacreditados e o efeito contrário se produz, ou seja, quem os vê não apenas desacredita que todo prazer é ruim, como passa a acreditar que todo prazer é bom. Em outros termos, quando as palavras se contrapõem aos fatos percebidos, elas perdem seu valor de verdade. Como não é verdade que todo prazer seja ruim, já que isso não se apresenta na prática, fazer uso de tal argumento é ineficaz, "pois os argumentos sobre as emoções e ações são menos confiáveis (pistoi) do que os fatos; e quando eles divergem do que é percebido (toîs kata aisthêsin), eles são depreciados, bem como a verdade é desacreditada” (1172a34-b1).

Disto podemos inferir que a verdade, do ponto vista da moral, é prática, isto é, o valor do discurso moral se fundamenta nos fatos percebidos, pois se o

53 É tese bem estabelecida na Ética Nicomaqueia que a formação do caráter virtuoso depende do tipo de ação que se faz e sentimento que se tem com relação ao prazer e a dor. Essa relação será mais bem examinada na seção "Problema II: Prazer e virtude”, do próximo capítulo. 
discurso não corresponder aos fatos, não será nem crível, nem útil. Ao contrário, todo discurso que se harmonizar aos fatos será verdadeiro e de grande utilidade para o conhecimento e para a vida:

Discursos verdadeiros parecem, portanto, ser de grande utilidade não apenas para o conhecimento, senão também para a vida, pois como se harmonizam com os fatos, eles são críveis (sunoidoi gar ontes toîs ergois pisteuontai) e assim estimulam aqueles que os compreendem a viver de acordo com eles (1172b4-7).

Em suma, se os discursos e as opiniões, no âmbito ético, estiverem em desarmonia com os fatos, eles não serão apenas falsos, como também ineficazes, pois não cumpriram a finalidade prática de persuadir, incitar e orientar os homens a se tornarem bons, como bem explica Aristóteles ao comentar as opiniões de Sólon e de Anaxágoras sobre a doutrina da mediedade com relação aos bens externos:

As opiniões (doxai) dos sábios parecem, portanto, se harmonizarem com os nossos argumentos (tois logois). Porém, mesmo que elas sejam um tanto convincentes (echei tina pistin), a verdade, nas questões práticas, é discernida dos fatos e da vida (ek ton ergon kai tou biou krinetai). Isso porque eles são decisivos (kurion) nas questões práticas. É preciso, portanto, examinar o que já foi dito levando em conta os fatos e a vida, e aceitá-lo se estiver em harmonia com os fatos, mas considerá-lo meramente supositivo (hupolêpteon) se diferirem deles (ENX 8: 1179a17-23).

Por isso, um discurso não pode ter a sua verdade garantida por outro discurso, nem sua capacidade persuasiva se sustentará se não encontrar respaldo na discriminação (krinein) dos fatos.

No segundo capítulo do livro X (1172b9-1173a13), o filósofo passa a criticar a concepção hedonista extremada, segundo a qual o prazer é concebido como o bem supremo. Os argumentos que a sustentam são refutados em parte, pois, mesmo que a conclusão seja falsa, é possível preservar o que neles há de verdadeiro. Enfim, o que Aristóteles pretende mostrar é que os argumentos de Eudoxo não garantem a verdade da conclusão, a saber, de que o prazer é $o$ bem; porém, contribuem para a verdade da tese que o próprio Aristóteles defende, qual seja: a de que o prazer é um bem. Ou seja, se os argumentos hedonistas são verdadeiros é porque deles se conclui que o prazer é um bem, e não que ele seja $o$ bem. 
Primeiramente, ele apresenta os quatro argumentos de Eudoxo para identificar o prazer com o bem supremo (tagathos) (1172b9-25). O primeiro argumento se constitui do seguinte modo: (i) como todos os seres, racionais e irracionais, desejam obter o prazer; e (ii) aquilo que cada ser busca é um bem para si (to autôi agathon); (iii) então aquilo que todos os seres buscam deve ser o bem supremo (ariston). O segundo argumento é pela prova negativa, a saber: (i) como a dor é evitada por todos; (ii) o prazer, por ser oposto da dor, é desejado por todos, e se ele é desejado por todos, então ele deve ser o bem supremo. O terceiro argumento consiste em dizer que (i) aquilo que não se deseja como meio para outra coisa nem em vista de outra coisa é mais desejado; e (ii) o prazer é algo desejado em vista de si mesmo (kath'hautên hairetên); então (iii) o prazer deve ser o bem supremo; com efeito, isso parece ser evidente porque ninguém se pergunta com qual finalidade desejamos ter prazer. Por fim, o quarto argumento diz que (i) a adição de prazer a qualquer bem (como a conduta justa ou temperante) torna o bem mais desejável; pois (ii) só o bem pode aumentar o próprio bem; logo, (iii) o prazer deve ser um bem.

Quanto a este último argumento, Aristóteles o refutará dizendo que dele não se conclui que o prazer seja o bem supremo, embora possa se concluir que o prazer seja um bem (1172b26-33). ${ }^{54} \mathrm{O}$ argumento, todavia, parece contar contra a conclusão a qual Eudoxo pretende chegar. Isso porque um bem pode ser aumentado por outro bem, mas não o bem supremo, que já é maximamente bom. Ou seja, o prazer, se fosse o bem supremo, não poderia se tornar melhor ao ser acrescido a outro bem. Possivelmente, o outro bem, uma ação boa, por exemplo, se tornaria melhor ao ser realizada com prazer, isto é, ao ser acrescida de prazer. Segundo Aristóteles, o bem supremo não pode se tornar melhor com o acréscimo de outro bem, visto que ele é autossuficiente e maximamente bom. Isso significa que o prazer acrescido à felicidade não a tornaria melhor.

Ademais, o prazer, quando acrescentado de prudência, torna-se melhor, por isso ele não poderia ser considerado o bem supremo. Este argumento refutativo fundamenta-se no argumento em que Platão ${ }^{55}$ nega a possibilidade de o prazer

54 Tomás de Aquino (1993, § 1970) comenta esta passagem dizendo que, segundo Aristóteles, Eudoxo apenas prova que o prazer se encontra sob a categoria do bem, mas não que ele seja melhor do que qualquer outro bem. Isso porque também é verdadeiro de qualquer bem que, quando acrescido a outro, torna-se um bem maior do que se estivesse sozinho.

55 Cf. Filebo, 60a-61b. 
ser o bem supremo, pois o bem supremo não se torna mais desejável por adição de algo e o prazer se torna mais desejável com prudência (phronêsis), pois sem prudência, pensamento, memória e opinião verdadeira não seria possível ter uma opinião verdadeira de que se está tendo prazer, nem se poderia reconhecer que afecção está sendo experimentada, nem conservar alguma memória da referida afecção. Ou seja, sem pensamento não é possível saber se está tendo prazer e, muito menos, se este é o bom prazer. Sendo assim, o prazer não poderia ser o bem supremo.

Aristóteles, como vimos, refuta apenas o último argumento de Eudoxo, o que nos leva a supor que os outros argumentos ou são em parte verdadeiros ou já foram refutados anteriormente, visto que o filósofo estagirita não sustenta o hedonismo eudoxiano. O terceiro argumento, de que o prazer é o bem supremo por ser algo desejado em vista de si mesmo, já foi refutado em EN I 7. Neste capítulo, o prazer deve ser entendido, juntamente com outros bens como a riqueza, a inteligência e a virtude, como um bem a ser buscado em vista dele mesmo e também como um meio para a felicidade; pois apenas a felicidade é um fim desejado em vista de si mesmo (1097b1-6).

O primeiro argumento parece ser, em parte, verdadeiro, pois se todos os seres, inclusive os racionais, buscam o prazer, não poderíamos afirmar que todos buscam um mal para si; ao contrário, como todos buscam seu bem próprio, o prazer deve contar como um bem. $\mathrm{O}$ argumento, neste sentido, é verdadeiro; o que não implica que dele se possa concluir verdadeiramente que o prazer seja $o$ bem, embora certamente seja um bem. Como diz o filósofo, provavelmente se dirigindo a Espeusipo: "aqueles que negam que aquilo a que todos buscam é um bem, falam sem sentido” (1172b36-1173a1). O prazer é um bem tanto porque todos pensam e dizem que ele é bom (1173a1), como também pelo fato de todos os seres naturalmente o procurarem: "talvez mesmo em seres inferiores, há algo natural mais forte do que eles mesmos que busca o seu bem próprio" (1173a3-5). O argumento de que o prazer é um bem é verdadeiro, pois é impossível, como diz Tomás de Aquino, que a natureza falhasse em todos os casos. ${ }^{56}$

Em seguida, Aristóteles conclui o capítulo mostrando em que sentido o segundo argumento é verdadeiro (1173a6-13). Já vimos que o prazer, por ser perseguido por todos, deve ser um bem, como foi constatado pelo primeiro 
argumento. Porém, aqueles que, como Espeusipo, ${ }^{57}$ negam tal argumento afirmando o contrário não dizem a verdade. O argumento contrário é o seguinte: (i) que a dor seja um mal, não se segue que seu oposto, o prazer, seja um bem, pois (ii) o oposto de um mal pode ser tanto um mal como algo neutro; logo, o prazer, mesmo oposto a um mal, à dor, também poderia ser ele mesmo um mal. Aristóteles nos mostra que este argumento, de natureza lógica, pode ser rapidamente desfeito por outro de natureza prática, conforme o que se constata na realidade: (i) daquilo que os homens se afastam é um mal, e da dor todos se afastam, assim como (ii) aquilo que os homens perseguem é um bem e o prazer todos perseguem; logo, (iii) prazer e dor se opõem enquanto bem e mal.

Mesmo sendo refutado por Aristóteles, o argumento de Espeusipo parece se basear no fato de haver males que se opõem entre si. Um exemplo que, certamente, contaria a favor de Espeusipo, é o fato de que algo ruim pode se opor a algo ruim como o excesso se opõe à falta, pois os extremos em relação ao meio termo são ruins e se opõem entre si. Assim, a covardia, que é um mal, se opõe a temeridade, que é também um mal. Aristóteles não poderia deixar de assumir a verdade de tal exemplo. Porém, a dor não se opõe ao prazer como um mal se opõe a outro mal. Como diz o filósofo: "com efeito, se ambos, prazer e dor, fossem males, ambos teriam de ser evitados; agora, se ambos fossem neutros, nenhum seria evitado ou eles teriam de ser igualmente evitados" (1173a10-12). Contudo, o que vemos é que todos os homens evitam a dor como um mal e procuram o prazer como um bem; por isso, prazer e dor não são opostos como dois extremos maléficos se opõem. Desse modo, ao refutar o argumento de Espeusipo, Aristóteles preserva o que há de verdadeiro no argumento eudoxiano, a saber, que o prazer é buscado enquanto um bem, ao contrário da dor que é evitada enquanto um mal.

No capítulo 3 (1173a13-1174a12), Aristóteles faz o exame crítico das opiniões sobre o prazer de modo muito semelhante ao livro VII, capítulo 12 (1152b33-1153a2), que já examinamos. Desta maneira, não pretendemos fazer aqui a análise do capítulo por completo, mas apenas salientar alguns pontos. Em continuidade com o capítulo anterior, ele expõe e refuta quatro argumentos que defendem que o prazer não seria um bem, tampouco o bem supremo.

57 A atribuição é explícita em EN VII 13: 1153b1-7, em que o mesmo argumento é exposto e refutado por Aristóteles. 
O primeiro argumento é o da qualidade, pois diz que o bem é uma qualidade, e dizer que algo é bom é dizer da qualidade de algo (1173a13-15). Todavia, como o prazer não é uma qualidade, então ele não seria bom. A refutação aristotélica consiste em simplesmente dizer que a ação virtuosa e a felicidade são atividades e não são qualidades (poiotêtes), mas são boas. ${ }^{58}$ Portanto, é falso dizer que o bem se predica apenas da categoria qualidade, pois ele se predica de todas as categorias. ${ }^{59}$ Desse modo, mesmo que o prazer não seja uma qualidade, isso não significa que ele não possa ser um bem.

O segundo argumento é o da natureza determinada e consiste em dizer que o prazer não pode ser bom, já que o bem é determinado (hôristhai) e o prazer é indeterminado (aoriston), pois admite mais e menos (1173a16-29). Todavia, se o prazer não fosse bom por ser indeterminado, então não deveriam ser boas as atividades virtuosas, pois, mesmo que a virtude não possa ser mais ou menos virtude, a atividade pode ser mais ou menos virtuosa, visto que aquele que a possui pode ser mais ou menos virtuoso. Sabemos que, para Aristóteles, é possível ser mais ou menos virtuoso e agir mais ou menos de acordo com a virtude (1173a19). Neste sentido, é preciso fazer a seguinte distinção: algo pode ser mais ou menos prazeroso e alguém pode sentir mais ou menos prazer; mas o prazer, ele mesmo, a sua natureza, não é mais ou menos prazer. Do mesmo modo, uma vida pode ser mais ou menos feliz e um indivíduo pode ser mais ou menos feliz; mas a felicidade não é mais ou menos felicidade. Se admitir graus fosse a razão pela qual não se pudesse dizer que algo é bom, então não apenas a sensação prazerosa, mas a atividade virtuosa e a felicidade estariam excluídas da categoria do bem.

Com efeito, como este parece ser um argumento de Platão, presente no diálogo Filebo (27e), o Estagirita acusa-o de se contradizer ao assumir que todo prazer é indeterminado. Isso porque, segundo Platão, apenas os prazeres misturados são indeterminados, admitindo variação em graus, e não os puros; nesses não há mistura com a dor (52a-d). Ora, se todos os prazeres fossem indeterminados, não poderia haver prazer puro, tampouco haveria uma distinção em dois tipos: misturados e sem mistura.

58 Em EN VII 12, Aristóteles diz que o bem pode ser dito da disposição, que é uma qualidade e da atividade, que não é uma qualidade (1152b33).

59 Cf. EN I 4: 1096a23-24. 
Por fim, fazendo uso da saúde como paradigma, Aristóteles conclui a refutação dizendo que "ser determinado" e "variar em grau de mais ou menos" não são predicados contraditórios, podendo ser atribuídos a um mesmo sujeito, como a saúde. Ou seja, a natureza da saúde é determinada, pois é uma determinada proporção harmônica que pode ser considerada como um estado saudável, mas tal proporção varia conforme cada organismo. Em outros termos, a natureza da saúde é determinada, mas varia em graus, pois não existe na mesma proporção para cada indivíduo saudável. Isso não quer dizer que a natureza da saúde não seja determinada, mas que ela, assim como a beleza, varia conforme o objeto ao qual se predica, isto é, conforme aquele que compartilha da saúde a tenha em maior ou menor grau. Do mesmo modo, a natureza do prazer é determinada e, ainda assim, alguém pode senti-lo em maior ou menor grau.

O terceiro argumento é o da perfeição e consiste em dizer que o bem supremo é perfeito (teleion), mas o movimento (kinesis) e o processo de geração (genesis) são imperfeitos ou incompletos (ateleis), e, se o prazer é um movimento, então ele deve ser incompleto, portanto não poderia ser o bem supremo (1173a29-b21). Esse argumento também é de Platão e está presente no diálogo Filebo (53c-55b). Aristóteles refuta tal argumento ao negar que o prazer seja um movimento ou processo, como ele já fizera em EN VII 12. As razões, porém, que ele fornece são distintas daquelas fornecidas no livro VII. Como vimos, no livro VII, o prazer não é um processo, porque ele é um fim em si mesmo, isto é, uma atividade. Agora, a justificativa é que ele não é um movimento por não possuir velocidade, seja em absoluto, seja relativamente a um corpo. Isso porque podemos chegar ao prazer mais ou menos rapidamente, mas não podemos sentir prazer mais ou menos rapidamente. O fato mesmo de sentir prazer (hêdesthai) não comporta velocidade, nem se compararmos duas pessoas que estão, ao mesmo tempo, sentindo prazer. Nas palavras do filósofo:

É possível ter chegado rapidamente ao prazer, do mesmo modo com o ter tido raiva, mas estar tendo prazer rapidamente não, nem mais do que outra pessoa, assim como é possível com o andar, crescer e todas as coisas do tipo. É possível passar a ter prazer rápida ou lentamente, mas não atualizar (energein) o próprio prazer rapidamente, isto é, ter prazer (hêdesthai) (1173b1-5).

Sabemos que o movimento, ao contrário da sensação prazerosa, comporta velocidade. Um movimento lento é um pequeno deslocamento em um longo 
tempo e um movimento rápido é um grande deslocamento em um curto tempo. Apesar de podermos alcançar o prazer a partir de alguns movimentos, como andar, nadar, jogar, o próprio prazer não é movimento, pois sua natureza é completa desde sempre e não processual. Adiante, no quarto capítulo do livro dez, veremos que o filósofo retomará este argumento de modo mais detalhado, pois a determinação da natureza do prazer como um todo acabado implica que ela não seja processual, mas que exista enquanto uma atualização completa e acabada desde o momento em que ele surge. Neste sentido, a realização da natureza ou forma do prazer é pontual, como o ato de ver ou pensar. Alguém pode chegar mais ou menos rapidamente ao ato de ver ou pensar, mas o próprio ato de ver ou pensar é pontual e não processual. O mesmo ocorre com o prazer.

A refutação continua com a negação de que o prazer seja um processo de geração (genesis) (1173b5-20). Segundo o filósofo estagirita, o acaso (tuchon) não é gerado do acaso, nem mesmo qualquer coisa é gerada de qualquer coisa, mas tudo padece retornando para onde foi gerado. Se o prazer for a geração do que a dor corrompe, deve-se concluir que "a dor é a falta (endeian) do estado natural e o prazer o seu restabelecimento (anaplêrôsis)” (1173b8-9). Como já vimos também no livro VII, capítulo 12, Aristóteles atribui a Platão a definição do prazer como uma reparação de um equilíbrio ou preenchimento de uma falta dolorosa, pois, se a dor é a privação do que é conforme a natureza, então o prazer seria o restabelecimento. ${ }^{60}$ Ademais, se o prazer for o processo de restabelecimento, então ele será apenas corporal, pois se trata aqui da restauração ao estado natural como sendo um processo que ocorre no corpo. Depois de ter exposto o argumento de Platão, ele passa a explicar por que Platão teria chegado a esta conclusão e pouco se detém para refutá-la. Na verdade, seria mais correto dizer que ele apenas a nega em X 3, uma vez que ela já teria sido refutada em VII 12. Por isso, se a refutação já foi devidamente explicitada no primeiro Tratado, podemos supor, mais uma vez, que há um vínculo conceitual entre ambos os Tratados.

A opinião de que o prazer é um processo de restauração se fundamenta nos prazeres e dores ligados a estados físicos de privação, por exemplo, a fome e a

60 A definição do prazer como um mero preenchimento de uma falta dolorosa ou reparação do equilíbrio encontra-se no diálogo Górgias (496c-e) e no Filebo (31d-32a). Os exemplos que Platão costuma usar são os processos de saciação da fome e da sede. Tomás de Aquino (1993), por sua vez, explica esste argumento de Aristóteles do seguinte modo: a dor se segue quando se está privado do que lhe pertencia naturalmente, já o prazer se segue quando algo que pertence naturalmente ao homem é restabelecido àquele que estava privado. 
sede (1173b14). O exemplo da comida é paradigmático, pois, quando alguém se alimenta, a dor da falta de alimento é suprimida; portanto o prazer que acompanha tal processo é, de fato, precedido pela dor da falta. Desse modo, este tipo de prazer acompanha um processo de restauração. Porém, enquanto concomitante ao processo, ele deve ser dito prazer por acidente ou por concomitância; embora o filósofo não se refira aqui ao prazer acidental, visto que isto já foi bem estabelecido no primeiro Tratado. Com efeito, Platão se baseia em uma explicação puramente fisiológica em que o prazer e a dor são meramente processos corporais de falta e preenchimento das necessidades físicas ${ }^{61}$ Contudo, isto não ocorre sempre com os prazeres corporais, mas apenas quando eles acompanham processos de reabilitação e são antecedidos pela dor da falta. Ademais, alguns prazeres como o da sensação olfativa, auditiva e visual, do conhecimento, das memórias e das esperanças não são precedidos por dor. ${ }^{62}$ Desse modo, conclui o filósofo, “o prazer não é um processo de restabelecimento, embora possa acompanhá-lo, assim como a dor pode acompanhar um corte (temnomenos) ${ }^{63}$ " (1173b12-13), ou seja, assim como um corte não é uma dor, mas pode ser acompanhado de dor, um processo de restabelecimento ou convalescença não é o próprio prazer, embora possamos sentir prazer durante tal processo. Desse modo, a saciação da fome não é prazer, embora seja acompanhada do mesmo.

Quanto ao quarto argumento, o dos prazeres reprováveis, não é fácil vislumbrar o que o Estagirita pretende com ele (1173b21-1174a8). Aristóteles, de fato, não nega que haja prazeres reprováveis. Ele se preocupa, porém, em determinar quais são os critérios para estabelecer o valor moral do prazer, já que não há apenas prazeres reprováveis. Afinal, o prazer não pode ser por natureza reprovável, senão ele não poderia ser de modo algum um bem. A tese da diferença

61 Em Filebo, 31e-33e, Sócrates, ao iniciar o exame da natureza do prazer, começa pelos que são reconhecidamente prazeres, ou seja, aqueles que sentimos ao comer e beber. Porém, tampouco para Platão os prazeres se reduzem aos corporais. Há aqueles que são puros, como o prazer contemplativo. Desse modo, a crítica de Aristóteles não parece ser de todo aceitável; ao menos, não parece ser esta a definição de prazer puro que propõe Platão, pois o prazer que temos com o estudo, as lembranças e as esperanças não são preenchimentos de uma falta física que envolve dor (51b-52b). Para a comparação entre a concepção de prazer para Platão e Aristóteles, ver Riel (2000, cap. 1 “ Two paradigms: Plato and Aristotle").

62 Também em EN IX 4: 1166a25-30, memórias e esperanças agradáveis, diz-nos Aristóteles, são prazerosas.

63 O termo temnomenos pode ser entendido tanto sendo como uma cirurgia ou como um corte. Acreditamos que este último seja o caso, juntamente com Gauthier, Stewart e Riel. 
específica entre os prazeres é a resposta que Aristóteles dá à suposição de que a natureza do prazer seja reprovável. ${ }^{64} \mathrm{O}$ argumento, por sua vez, pode ser refutado de muitas maneiras, como Aristóteles mostrará em seguida.

Em primeiro lugar, é possível dizer que tais prazeres não são realmente prazeres, mas apenas para aqueles que são viciosos ou que estão em estados alterados ou em circunstâncias que provoquem alterações; ou seja, certas coisas parecem ser prazerosas relativamente a algumas pessoas que se encontram em certas situações de debilidade natural ou moral. Neste caso, algo que não seja absolutamente prazeroso pode ser tomado por alguém como prazeroso. As faculdades discriminativas certamente se alteram em estados de doença ou de fortes emoções. ${ }^{65}$ Além do caso do vicioso, o filósofo estagirita nos fornece os seguintes exemplos: o doente não pode ser parâmetro para o que é saudável, pois algo pode parecer saudável ao doente, mas não sê-lo realmente. Do mesmo modo, no caso da percepção, uma alteração que debilite o percipiente impedirá que o objeto seja apreendido corretamente; por exemplo, um daltônico não verá o vermelho de um objeto que seja realmente vermelho. Com relação à discriminação do que é prazeroso não poderia ser diferente, ou seja, aquilo que de fato é prazeroso é o que é percebido por alguém que não esteja debilitado natural ou moralmente, a saber, uma pessoa que esteja em perfeito estado natural. ${ }^{66}$

Em segundo lugar, também é possível refutar tal opinião a partir do que podemos chamar de critério objetivo, pois, além do sujeito que sente prazer, o próprio objeto prazeroso deve servir como um critério de referência. A refutação consiste em considerar a diferença específica que há entre os prazeres a partir de suas fontes. Há belas (kalôn) fontes, mas há também as vergonhosas (aischrôn). Por isso, não são todos os prazeres reprováveis, mas apenas aqueles cuja fonte é vergonhosa. Por esta mesma razão, Aristóteles nos diz que o prazer produzido pelo amigo e pelo bajulador diferem em espécie, pois o bajulador visa somente dar prazer ao outro e não o seu bem, enquanto o amigo visa o bem do outro e não simplesmente dar prazer. Neste sentido, é reprovável o prazer cuja fonte é a bajulação, mas

64 Gauthier (2002), seguindo Burnet, compreende que Aristóteles, uma vez tendo refutado a opinião de Espeusipo de que nenhum prazer é bom, passa agora a refutar a opinião de Platão, expressa em 1152 b10 e 20-22, de que a maioria dos prazeres, a saber, os corporais, é ruim, embora alguns prazeres, a saber, os puros, sejam bons.

65 Sobre este ponto, ver o Tratado do Sonho ou De Insomniis, de Aristóteles.

66 Este ponto já foi mais bem explicado em EN VII 12. Cf. EE VII 2 1235b31-1236a1. 
elogiável se a fonte for a amizade. Outro exemplo são os prazeres infantis, que diferem dos prazeres dos adultos, pois nenhum adulto, a princípio, escolheria viver como uma criança por toda a vida para maximamente desfrutar de prazeres infantis. Um adulto que assim escolhesse, fruiria de prazeres reprováveis e seria, de modo censurável, um adulto infantil. Do mesmo modo, ninguém, a princípio, desejaria sentir prazer em fazer atos extremamente infames, mesmo sem quaisquer consequências punitivas, pois este seria um prazer reprovável. Ao contrário, são prazeres louváveis aqueles que provêm de bela fonte e de um bom caráter, isto é, de ações que escolheríamos fazer e nos dedicaríamos a fazê-las, mesmo se não nos dessem prazer, como ver, lembrar, saber e possuir virtudes. O fato de, supostamente, estas atividades não implicarem prazer traduz a tese defendida pelo filósofo de que uma ação boa não é boa por ser prazerosa, ou seja, de que uma ação boa não é necessariamente prazerosa e que não precisaria ser prazerosa para ser desejada. Ou seja, o bem é desejado por si mesmo, independentemente do prazer que possa dele resultar. Há, portanto, primazia do bem sobre o prazer; não que o bem exclua o prazer, mas, antes do que o prazer, o bem é o que deve mover nossos desejos e ações. Por isso, mesmo se não nos desse prazer, desejaríamos o que é bom $^{67}$. Desse modo, o que é de fato bom é naturalmente e por princípio desejável, mesmo que não seja aprazível.

Em suma, os prazeres diferem seja com relação à qualidade moral do objeto prazeroso, seja com relação à qualidade moral daquele que o sente. Em alguma medida, vemos aqui um prenúncio da tese da diferença específica entre os prazeres, que será mais bem desenvolvida no capítulo 5 do livro $\mathrm{X}$. Por enquanto, podemos constatar que a diferença entre os prazeres não faz uso de um critério puramente acidental. Com efeito, veremos que há certos prazeres que necessariamente acompanham certas atividades por lhes pertencerem e não porque eles acontecem casualmente de acompanhá-las. Há prazeres que são próprios das atividades virtuosas e outros próprios das viciosas, o que explica o fato de que o temperante jamais encontraria prazer nas atividades que costuma realizar o intemperante. Por isso, na mesma medida em que as atividades do intemperante devem ser evitadas, também devem ser os prazeres que lhes são próprios. ${ }^{68}$

67 Cf. EN X 3: 1174a4-8. Sobre esse ponto ver seção "Problema II: Prazer e virtude", do próximo capítulo.

68 Sobre esse ponto, é interessante ver o "Problema 2: que os prazeres não são os mesmos em tipo" de Alexandre de Afrodisia, em Problemas Éticos (1990). 
No capítulo 2, Aristóteles pretendeu mostrar em que sentido Eudoxo estava errado, embora não estivesse totalmente. Por um lado, a sua concepção do prazer como sendo o bem supremo não se verifica na realidade, pois nem seus argumentos, nem o fato de haver prazeres reprováveis sustentam tal hedonismo extremo. Por outro, mesmo que o prazer não seja o bem supremo, não poderia ser excluída a possibilidade de que ele seja um bem sob certas condições criteriosas já anunciadas no capítulo 3, mas que serão mais bem desenvolvidas no capítulo 5. Esta parece ser a solução dada a partir dos argumentos que refutam tanto a opinião de que o prazer é um mal em absoluto, como a de que ele seria o bem em absoluto.$^{69} \mathrm{O}$ capítulo 3, portanto, conclui o que foi investigado do início do Tratado até aqui com a seguinte afirmação: "Parece, portanto, estar claro que nem o prazer é o bem supremo (tagathon), nem todo prazer é desejável (hairetê), e que alguns prazeres são desejáveis neles mesmos (hairetai kath'hautas), diferindo os prazeres especificamente ou por suas fontes" (1174a9-11). Ou seja, o prazer não é o bem supremo porque há prazeres reprováveis; e, justamente por haver prazeres reprováveis, nem todo prazer deve ser desejado. Porém, aqueles cuja fonte é boa, como a sabedoria e a virtude, estes não apenas são desejáveis por si mesmos, como também devem ser desejados, ou seja, devemos aprender a desejá-los.

Para finalizarmos a análise do segundo Tratado, passemos da parte crítica (do capítulo primeiro ao terceiro) para a parte positiva (1174a14-1176a29: dos capítulos 4 e 5). Depois de examinar as divergências das opiniões, as suas contradições e insuficiências, o filósofo diz que começará por um novo início para explicar com mais clareza o que é (ti estin) o prazer ou qual é a sua qualidade essencial (poîon ti).${ }^{70}$ Será sobre esta definição que iremos nos deter.

69 Irwin (2007, p. 169) sintetiza bem essa trajetória argumentativa: "Ele [Aristóteles] simpatiza com alguns dos argumentos que Aristipo e Eudoxo usam para defender o hedonismo (EN 1172b925), mas não acredita que eles possam sustentar o hedonismo. Acredita que ajudam a responder a tese exagerada de que o prazer não é um bem de modo algum. Ele concorda com os hedonistas ao acreditar que o prazer é um bem, mas rejeita a afirmação mais forte de que o prazer é o bem" (1172b26-35).

70 Aristóteles procede da mesma maneira no De Anima. Todo o primeiro livro é dedicado ao exame crítico (historia) das opiniões sobre a alma e o início do segundo livro à sua própria definição de alma, no qual ele diz "começar novamente" para determinar a natureza de seu objeto, a alma, com mais precisão e clareza (DA II 1: 412a2). 
A definição é formulada tanto em contraposição à natureza do movimento e da geração, como em comparação com o ato de ver (1174b33-35). Aristóteles nos fornece gradativamente os atributos do prazer até chegar à definição propriamente dita. O primeiro atributo é ser um todo completo. Trata-se de dizer que o prazer não é um processo de geração, nem um movimento, pois tanto um quanto o outro são de naturezas inacabadas, ao contrário do prazer, que é um todo acabado indivisível. Dizer que ele é um todo completo significa dizer que, ao contrário do que Platão afirmava, o prazer pode pertencer à categoria do bem, isto é, ele pode ser um bem, tendo em vista que ele não é um movimento e nenhum movimento, para Platão, poderia estar na categoria do bem. Ser um bem é ser um fim ou perfeição e não algo imperfeito e inacabado, que visa um fim, mas que não é ele mesmo um fim. Pois bem, o prazer é um certo fim ou perfeição (ti telos), o que garante a possibilidade de ele ser um bem. Se é um todo completo, ele é, como o ato de ver, um certo fim ou perfeição. Tudo o que o filósofo quer é garantir como este argumento é a possibilidade de o prazer ser um bem, o que implica refutar a tese platônica de que ele é movimento. Garantir que ele possa ser um bem não nos garante que ele o seja de fato; para tanto, como veremos, o filósofo lança mão de outros dois atributos: ele pertence (oikeîa) a uma atividade e ele aperfeiçoa (teleîoi) esta atividade a qual pertence. Pertencer a uma atividade significa ter sua natureza determinada pela natureza da atividade, o que implica afirmar que a qualidade moral do prazer depende da qualidade moral da atividade que ele acompanha. Eis a garantia de que um prazer é de fato bom: quando ele pertence a uma boa atividade. Eis a função do prazer: aperfeiçoar tal atividade. Passemos a análise de cada um desses atributos: ser um todo completo, ser certo fim ou perfeição, pertencer a uma atividade e aperfeiçoar tal atividade.

A argumentação para se chegar à definição de prazer não é clara, tampouco é fácil de compreender. O filósofo inicia a argumentação fornecendo o primeiro atributo do prazer ao compará-lo com o ato de ver. Ora, se ele é um todo completo, então é porque ele é como o ato de ver, que não necessita de nada que venha a completar a atualização de sua forma ou essência (ềdos). Este primeiro argumento prova que o prazer não é um movimento, pois diz que todo movimento, por ser um meio para um fim, é incompleto (ateleios) até que seja finalizado, e o prazer, por ser um fim em si mesmo, é completo desde o início (1174a19-b9). Sabemos que todo processo de mudança, portanto todo movimento e toda geração, só acaba quando chega ao seu término e quando a consideramos a partir da totalidade de sua duração. Como diz Aristóteles: 
Todo movimento envolve tempo (en chronôi) e existe em vista de um fim, como a construção; ele é completo (teleia) quando produziu o que visava produzir. Portanto, ele é completo apenas no inteiro tempo ou no término. Em suas partes e nos tempos que ocupam, todos os movimentos são inacabados e diferentes em espécie entre si e do todo (1174a19-22).

O movimento, cuja natureza é processual e divisível, não pode ser dito em si mesmo como um todo completo, mas apenas se considerado em sua inteira duração e a partir de sua finalização. Por exemplo, só dizemos que o processo de construir uma casa se completa com a construção da casa, que é a finalidade de tal processo. As partes do processo de construção são movimentos inacabados que ocorrem em períodos de tempo distintos, como as ações de fazer a fundação, preparar o cimento, colocar os blocos, as colunas etc. Essas partes são distintas entre si e do processo de construir considerado como um todo ao qual pertencem. Como as suas partes são distintas e inacabadas, o movimento, enquanto um todo, não pode ser considerado pelas suas partes, e sim em sua inteira duração e em sua finalização ou atualização completa de sua forma (ê̂dos). O prazer, ao contrário, é acabado, pois sua forma é completamente atualizada desde sempre ao surgir e não existe senão em vista de si mesmo; ou seja, ele não tem nenhuma outra finalidade senão a sua própria existência.

Se o prazer não é um movimento, então resta apenas que ele seja, assim como o é a atividade de ver e pensar, uma atualização completa ou perfeita de sua natureza. Como o capítulo 4 é um tanto lacunar quanto às explicações dos conceitos, parece ser adequado recorrermos às definições de movimento (kinêsis) e de atualização ou atividade (energeia) fornecidas no sexto capítulo do livro IX da Metafísica (1048a35-b9); capítulo no qual Aristóteles distingue, por analogia, atualidade e potencialidade.

Segundo o filósofo, kinêsis e energeia são tipos de ações (praxeis) e toda ação é uma atualização de uma potência, isto é, uma energeia - termo que, por sua vez, significa tanto atualização como atividade. Sabe-se que toda mudança ou movimento é atualização de potência, mas nem toda atualização de potência é uma mudança, pois há um tipo de atualização que é completa e esta o Estagirita denomina de atividade (energeia). O movimento (kinêsis), por sua vez, é uma ação com limite (peras), ou seja, uma ação ou atualização incompleta (energeia atelês) ${ }^{71}$ que 
cessa ao atingir o seu fim. Já a atividade é uma ação completa, cujo fim lhe é intrínseco e que não cessa por si mesmo, sendo por natureza interminável.

Há, portanto, ações que têm limite e outras que não têm. As que têm limite não são fins (telos) nelas mesmas, mas existem em vista de um fim a ser obtido ao término da ação. Esta ação não é completa ou perfeita e Aristóteles a denomina de movimento. Há ações que são ilimitadas e estas são as que o fim é a sua própria realização. Esta ação é completa ou perfeita e Aristóteles a denomina de atividade (energeia). No caso da atividade, a atualização de sua natureza é completa desde o seu surgimento, ou seja, é igualmente plena em qualquer período do tempo, ao contrário do movimento, cuja atualização da natureza ou forma (eîdos) se efetiva no decorrer do tempo.

Ackrill (1997, p. 145), em seu belo artigo "Energeia and Kinêsis”, expõe com clareza as três características que definem a atividade distinguindo-a de movimento: (i) ausência de limite; (ii) continuidade indefinida; e (iii) atualização por completo em qualquer período do tempo. A continuidade indefinida e ilimitada, sem outro propósito primeiro senão a realização de si mesmo, permite que a atividade seja realizada sem cessar, como é o caso do primeiro motor, divino e sem matéria, capaz de pensar e ter prazer sem cessar; ao contrário de nós, seres materiais, complexos e mutáveis, que não realizamos a mesma atividade sem cessar por sermos incapazes, pois constantemente mudamos e assim nos exige nossa matéria corporal, caso contrário, seríamos deuses e pensaríamos e teríamos prazer ad indefinitum, como nos mostrou o filósofo em EN VII, 14, 1154b22-32. Disto podemos inferir que a necessidade de parar de ser realizada não é própria à natureza da atividade, enquanto o movimento tem que parar ao chegar ao fim por uma necessidade própria à sua natureza.

Sabemos que a ação moral, diferentemente da produtiva, possui fim em si mesma. ${ }^{72}$ A produção de uma casa é um movimento, cujo fim, a casa, lhe é extrínseco (1174a20). A ação produtiva, portanto, é uma atualização que se completa com o seu próprio término. Já as atividades como pensar, sentir e agir moralmente são completas em si mesmas e o fim primeiro ${ }^{73}$ é a sua própria realização; como diz o filósofo, "a completude (teleia) está contida nelas”

72 Ver EN I e VI.

73 Denomino fim primeiro aquele em vista do qual algo primeiramente existe. O ter prazer, assim como o perceber e o pensar, existem primeiramente em vista deles mesmos, mas, secundariamente, em vista da sobrevivência e do bem viver ou eudaimonia. 
(Met. IX 6: 1048b22). Por isso, em EN X 4, ele diz: "o ato de ver parece ser completo (teleia) em qualquer momento de sua duração. Nada lhe falta que irá mais tarde completar a sua natureza (teleiôthêsetai to eîdos)" (1174a15-16). Do mesmo modo com prazer: "ele é um todo (holon), não haveria momento algum em que se pudesse tomar um prazer cuja essência (eîdos) viria a se completar ao longo do tempo" (1174a17-18). Isso não significa que essas atividades não ocorram no tempo, mas que a atualização de sua forma é instantânea, isto é, sua forma é completa desde o início do exercício da atividade. Não há necessidade da passagem do tempo para que ela venha a ser o que ela é, como ocorre com o movimento.

Com relação à atualização completa, Aristóteles também a explica como a ocorrência de uma atividade que se expressa segundo dois aspectos verbais em grego: o infectum e o perfectum. O primeiro aspecto retrata a continuidade da ação e o segundo, o estado resultativo da ação. Ou seja, quando realizamos a atividade de ver, como exemplifica o filósofo, estamos vendo e nos encontramos em um estado resultante da ação de ver, isto é, vemos e acabamos por ver ao mesmo tempo. Estamos vendo e nos encontramos em estado de afecção visual provocada pelo objeto visível. Da mesma maneira, exercitamos o pensamento e nos encontramos em estado cognitivo. Em outros termos, poderíamos dizer que quando vemos já vimos. Trata-se de um presente acabado. Por isso, nem o presente (eu vejo), nem o pretérito perfeito (eu vi) traduziriam o aspecto verbal contido no gerúndio composto: tendo visto. $\mathrm{O}$ aspecto verbal matizado por esta locução da língua portuguesa é o do presente acabado, isto é, nem presente, nem passado, mas algo intermediário. Quando estamos vendo, poderíamos dizer que vemos e já vimos ao mesmo tempo, portanto, vemos tendo visto. Nas palavras do filósofo:

Ao mesmo tempo, nós estamos vendo (horâi) e vimos (heôrake), estamos compreendendo e compreendemos, estamos pensando e pensamos (enquanto não é verdade que, ao mesmo tempo, estamos aprendendo e já aprendemos, ou, estamos sendo curados e já fomos curados) (Met. IX 6: 1048b23-25).

O mesmo é dito nas Refutações Sofísticas, quando Aristóteles procura mostrar que ver difere de fazer ou produzir: "É possível ao mesmo tempo fazer e ter feito a mesma coisa? Não. Mas é possível ver algo e ao mesmo tempo ter visto a mesma coisa” (178 9$)$. 
Aristóteles nos fornece outro exemplo: "estamos vivendo e vivemos" ou "eu vivo e tenho vivido”. Não se trata, neste caso, de um processo de geração, pois o processo é um movimento que se completará e cessará com o seu término. Por isso, não podemos dizer que alguém caminha e que já caminhou enquanto esta pessoa estiver caminhando; da mesma maneira, para aquele que está construindo, se curando, vindo a ser, mudando ou se movendo (1048b30-3). Por outro lado, podemos dizer que alguém está vendo e já viu, está pensando e já pensou ao mesmo tempo. Daí conclui o filósofo que este último caso é uma atividade (energeia) e o primeiro, um movimento (kinesis) (1048b35).

Em suma, ao vermos, o ato mesmo de ver já está completo e a sua forma perfeitamente atualizada. Não passamos gradativamente da cegueira à visão a cada ato de ver. O prazer, seguindo esta analogia, é uma atualização completa, ou seja, enquanto sinto prazer já me encontro em estado de fruição. É este aspecto de completude que parece indicar o que é ver ou ter prazer. Desse modo, não poderíamos dizer que o ato de ter prazer não existe no tempo. Ele é antes um ato que acontece agora e pontualmente do que um vir a ser que se desenrola ao longo do tempo. Não há, portanto, a necessidade de tempo para que a sua atualização se complete, pois que ela já é completa desde o instante em que passou a existir. Tomás de Aquino comenta de modo esclarecedor esta passagem ao dizer que um espaço de tempo não pode ser acrescido à realização do prazer, pois o prazer não necessita de um tempo a mais para completar a sua forma, como necessitam aquelas atualizações que são processuais. Por exemplo, o momento de geração de um ser humano requer uma quantidade de tempo para que a forma humana esteja perfeita, já o prazer é uma atualização de uma forma acabada, que não precisa ser aperfeiçoada ou completada ${ }^{74}$. Assim, conclui Aristóteles o seu primeiro argumento ao dizer que "a essência (ê̂dos) do prazer é completa em qualquer instante do tempo. Por isso, é evidente que o prazer não é o mesmo que o movimento, sendo um certo todo e algo completo (holôn ti kai teleiôn)” (1174b6-8). Dizer que sua atualização é completa desde que passou a existir implica dizer que o prazer é antes uma energeia, no sentido de atualização completa, do que um movimento, no sentido de atualização incompleta, como bem distingue o filósofo em Metafísica IX 6: 
Todo movimento é incompleto (atelês), como o estar diminuindo, aprendendo, andando, construindo: esses são movimentos e são incompletos. Não é, pois, a mesma coisa que, ao mesmo tempo, está andando e andou, ou está construindo e construiu, ou está se gerando e se gerou, ou está se movendo e se moveu: são coisas distintas. Também são distintos o que move e o que moveu. Mas a mesma coisa, ao mesmo tempo, está vendo (horâi) e viu (heôrake), está pensando (noei) e pensou (nenoêke). Denomino este de atividade (energeia) e aquele de movimento (kinêsis) (1048b28-35).

Por fim, se o prazer certamente é uma atualização completa (energeia teleia), ${ }^{75}$ então podemos inferir que ele é uma atividade e que, a partir de uma passagem do De Anima, ele deve ser entendido como uma atividade sensível de fruição. Como atesta o filósofo, temos a sensação de prazer quando, por meio da faculdade perceptiva, percebemos algo como sendo bom:

A sensação é, então, como a simples asserção ou simples pensamento (noeîn) e quando há algo prazeroso ou doloroso, a sensação, como que afirmando ou negando, busca ou evita. Com efeito, sentir prazer e dor é exercer uma atividade, por meio da faculdade perceptiva, em direção ao bem ou ao mal enquanto tais (kai esti to êdesthai kai lypeisthai to energein têi aisthêtikêi mesotêti pros to agathon ê kakon) (DA III 7: 431a8-13).

É preciso ter em mente que, na Ética Nicomaqueia, o filósofo estabeleceu uma analogia entre prazer e ver e não uma identificação. Ele mesmo insiste na distinção entre sensação e prazer no segundo Tratado. ${ }^{76}$ No De Anima, esta identificação tampouco ocorreria. Trata-se de compreender que o prazer não é idêntico, por exemplo, à sensação de ver, mas que pode ser entendido como uma atividade em direção ao bem ou ao que percebemos como sendo bom, portanto, uma atividade que depende deste tipo particular de percepção. Ou seja, se aquilo que vemos também o percebemos como sendo bom, então temos simultaneamente a sensação de ver algo e ter prazer com o que vemos. Como se pode notar, há duas atividades simultâneas: a de ver algo e a de sentir prazer ao estar vendo algo. Em termos gerais, podemos traduzir do seguinte modo: há,

75 Assim também concebem Gosling e Taylor (1982), cap. “Kinesis and Energeia“, paragrafo 16.2.6, p. 312. 
simultaneamente, a atividade de apreender algo como sendo bom e a atividade de sentir prazer com isto que parece ser bom. O prazer, portanto, é uma atividade perceptível, pois nós o percebemos quando o sentimos. Não haveria prazer se ele nos passasse desapercebido. Assim, o prazer é uma atividade perceptível de fruição que ocorre necessariamente quando algo nos parece ser bom, isto é, quando se nos manifesta um bem aparente (phainomenon agathon). É importante enfatizar que o prazer, mesmo que ele seja uma atividade dependente da percepção, também pode ocorrer quando imaginamos, lembramos ou pensamos em algo bom; enfim, quando simplesmente algo nos aparece como sendo bom.

Visto que o prazer é um tipo atualização completa (teleios), devemos esclarecer mais detidamente este atributo. Sabemos que teleios se diz, ao menos, de três modos, como atesta Metafísica V 16. Será, pois, esclarecedor compreender em que sentido o filósofo atribui ao prazer tal predicado. O primeiro e o segundo sentidos nos interessam mais do que o terceiro. $\mathrm{O}$ terceiro sentido diz que consumado ou acabado é aquilo que foi finalizado. Neste sentido, algo é teleios quando está finalizado, acabado ou consumado, como o movimento, por exemplo. Como vimos em 1174a19-b6, ele seria completo apenas quando finalizado e poderia ser considerado um todo unicamente a partir de seu fim. $\mathrm{O}$ prazer, porém, não pode ser dito completo neste sentido, mas no primeiro, a saber: completo per se, do qual parte alguma pode ser retirada, mesmo porque ele não é um todo completo, cujo fim lhe é extrínseco, mas é ele próprio um fim ou completude em si mesmo. ${ }^{77}$ Ao primeiro sentido, portanto, cabe bem a tradução por completo, a saber: "algo fora do qual não se pode tomar parte alguma, por exemplo, o tempo completo (teleios) de cada coisa é aquele fora do qual não se pode tomar nenhuma parte de tempo" (1021b13-15). Ao segundo sentido é mais adequada a tradução por perfeito, a saber: "aquilo que, quanto à excelência (aretê) e ao bem (eu), não se pode ser superado em seu gênero; como um médico e um músico são perfeitos quando nada falta em relação à forma (eîdos) de sua excelência própria" (1021b15-18). ${ }^{78}$

77 Sobre os três sentidos de teleios, ver comentário de Ross (1924).

78 Cito em inglês uma tradução que me parece conveniente: "We call complete, in our sense, that outside which not even one portion is to be found, as for instance the complete time of each thing is that outside which there is no time to be found which is part of that time: also, that which in respect of excellence and goodness cannot be surpassed relative to its genus, as for instance a doctor is 
Enquanto o completo parece concernir a um atributo que existe por natureza, o perfeito concerne a um atributo que vem a ser adquirido por prática, como a virtude moral ou a excelência técnica. Por um lado, a completude é constituidora da natureza da coisa desde que a coisa passou a existir, como o prazer que é completo desde o instante em que passou a existir. Já a perfeição, por outro lado, constitui a natureza não primária, mas secundária, ou seja, ela se atribui a uma "segunda natureza" que se adquiriu por aperfeiçoamento, como a virtude moral e qualquer outra disposição (hexis) que seja adquirida ou aprendida. Ora, assim como o ato de ver, o prazer não pode ser adquirido e aperfeiçoado pela prática, por isso, o sentido de perfeito não parece ser o mais adequado. Sendo assim, o atributo teleios, quando referido ao prazer, deve ser entendido como completo. E quando referido à atividade virtuosa, perfeito. Agora, em qual sentido o prazer aperfeiçoa (teleiô̂) uma atividade (1174b33), veremos no decorrer desta análise. ${ }^{79}$

Com efeito, certamente não se poderia aperfeiçoar, no sentido de aprimorar, o ato de ver stricto sensu. Não parece fazer sentido dizer que vemos melhor ou que a nossa visão se tornou perfeita por ter sido exercitada, como dizemos quanto ao pensamento. Pensamos mais e melhor quanto mais exercitamos o pensamento. Em outras palavras, quanto mais pensamos, mais somos capazes de pensar objetos inferiores. Por isso, a aquisição de conhecimento consiste no aperfeiçoamento da capacidade de conhecer, que se dá no seu exercício ou atualização. ${ }^{80}$ Ao percebemos, porém, não adquirimos mais capacidade de perceber, nem percebemos melhor ou destruímos a nossa capacidade perceptiva. Não existe aquisição de percepção, mas de conhecimento sim. ${ }^{81}$ Sendo assim,

complete and a flautist is complete when they are without deficiency in respect of the form of their proper excellence" (1021b12-18). A tradução de Christopher Kirwan (Aristotle: metaphysics Books 4, 5 e 6. 2003) é bastante clara, porém, a mesma palavra, teleios, apresenta dois sentidos distintos e deveriam, como propus, receber duas traduções distintas. Por isso, discordamos da tradução de teleios por completo em seu segundo sentido. Conforme o comentário do tradutor, há três sentidos e, portanto, três traduções possíveis do termo: "entire, perfect and complete". Apesar de apontar tais sentidos, Kirwan não explicita o significado, nem faz uso deles em sua tradução.

79 Ver mais adiante, da seção "Problema I: a função do prazer".

80 Ver DA: 417b12-16. Quanto a este ponto, ver Burnyeat (2002) e Zingano (1998, p. 87-98).

81 "É, pois, pelo exercício do conhecimento que aquele que possui conhecimento torna-se tal em ato: e isso ou não é uma mudança qualitativa (pois há desenvolvimento para a própria natureza e atualidade), ou ainda é uma mudança qualitativa de outro tipo" (DA II 5: 417b5-15). Em De Anima II 5, Aristóteles parece sustentar a tese de que a aquisição e o uso do conhecimento adquirido se traduzem 
não há uma excelência no ato de perceber e, analogamente, tampouco no ato de ter prazer; logo, não há como atribuir perfeição à fruição de prazer, como se sua natureza fosse aperfeiçoável. Em suma, do que foi dito, resta-nos a certeza de que o prazer é teleios no sentido de ser completo.

Voltando à análise de EN X 4, é preciso esclarecer que Aristóteles, ao atribuir à natureza do prazer a característica de ser "um todo completo" (1174b8), não quer dizer que o ato de prazer não se realiza ao longo do tempo, mas que a completude a que se refere diz respeito à atualização da essência (ềdos) do prazer no instante mesmo em que ele passou a ocorrer. Devemos compreender que a atualização da essência do prazer, por ser completa a todo instante de sua duração, não precisa de tempo para ser atualizada e, por isso mesmo, não pode ser dita processual. Todavia, não podemos negar que haja certa duração na qual transcorre $o$ ato de ter prazer. Mesmo porque a fruição ou sensação ${ }^{82}$ de prazer perdura $o$ tempo que durar a atividade prazerosa, como a atividade ver ou pensar. Por isso que tanto a sensação de prazer, como o próprio prazer, ocorrem no tempo. O que, porém, deve ficar claro é que o prazer não é um movimento, pois a atualização de todo movimento ocupa um espaço de tempo, enquanto a atualização de natureza do prazer não ocupa um espaço no tempo. Como diz Aristóteles: "não é possível se mover senão ao longo do tempo, mas é possível sentir prazer (hêdesthai), pois aquilo que existe no agora é certo todo (to gar en toi nun holon ti)" (1174b9). Seria erigir um paradoxo se disséssemos que não é possível sentir prazer durante o tempo em que esteja ocorrendo a atividade prazerosa, mas também - e é isto que pretende defender Aristóteles - não é porque o prazer ocorre por certo tempo que ele deva ser considerado um movimento ou um processo de geração, pois, uma vez que haja prazer, ele existe enquanto um todo completo imediatamente.

Como argumento suplementar, ao dizer que o prazer, por ser um todo, é indivisível, ou seja, que ele não é composto de partes que vão se atualizando no decorrer do tempo, o filósofo nega, mais uma vez, que o prazer seja um movimento ou um processo de geração, pois apenas coisas divisíveis são movimentos ou

por um aperfeiçoamento, isto é, "a coisa se desenvolve em direção à sua própria natureza e atualidade" ou "em direção às disposições e à natureza". Parece-nos, como foi dito, que há aperfeiçoamento de uma natureza que permita ser aperfeiçoada, como ocorre com toda função cognitiva. O prazer, por sua vez, não é do mesmo tipo de natureza que a da função cognitiva.

82 Refiro-me à sensação de prazer simplesmente pelo fato de que somos capazes de perceber que estamos tendo prazer quando ele ocorre. 
processos (1174b10-14). Portanto, mesmo que o prazer ocorra no tempo, isso não significa que sua natureza possa ser dividida em espaços de tempos. Esse argumento esclarece o anterior, pois como o prazer é um todo indivisível quanto à sua essência, mesmo que o tempo possa ser dividido espacialmente, a atualização do prazer não se faz ao longo dos espaços de tempo. Em suma, apesar de a nossa sensação de prazer transcorrer no tempo, a realização de sua natureza é desde sempre completa e não se dá ao longo do tempo, mas imediatamente.

Depois de ter fornecido o primeiro atributo do prazer, a saber, que ele é um todo completo indivisível, Aristóteles finalmente chega à tão esperada definição de prazer (EN X 4, 1174b33-35). Em verdade, a definição não é fornecida de modo claro e contundente, mas por acréscimo de atributos no decorrer dos capítulos 4 e 5 . Dizer que o prazer é um todo completo indivisível apenas garante que a sua natureza não seja processual e que, portanto, ele possa ser um bem. Todavia, ainda é preciso dizer em que sentido e sob quais critérios podemos efetivamente considerá-lo um bem, pois dizer que ele é um todo completo indivisível certamente não nos fornece critérios mais precisos de valoração moral sobre a natureza do prazer; apenas garante que ele possa ser um bem por não ser um processo. O critério, como veremos em EN X 5, dependerá da natureza da atividade à qual ele pertence. Passemos a definição propriamente dita.

O prazer é definido como um fim ou perfeição que sobrevém e retroage sobre a própria atividade à qual pertence. Tal definição fora obtida da análise dos capítulos 4 e 5 como um todo, mas, sobretudo, das linhas 1174b33-35: "O prazer aperfeiçoa a atividade, não como uma disposição que reside no agente, mas como uma perfeição que sobrevém, como a flor da idade na vida”. Devemos, primeiramente, entender em que sentido o prazer é próprio ou pertence (oikeia) a uma atividade e em que sentido ele é capaz de aperfeiçoá-la (teleiô̂). Em seguida, devemos examinar o que significa dizer que o prazer é um fim ou perfeição que sobrevém à atividade (epigignomenon ti telos) (1174b33). Ao definir o prazer deste modo, Aristóteles continuará a explicitar a definição mostrando o que é uma atividade perfeita e como o prazer a aperfeiçoa. Passemos agora à análise dos atributos "aperfeiçoar" (teleiô̂) e ser "próprio” ou "pertencer" (oikeia) a uma atividade.

Em primeiro lugar, podemos dizer que oikeia significa "pertencer" ou "ser próprio a”. No caso, o prazer que pertence a uma atividade é aquele que vem a ser em virtude da natureza da própria atividade, ao contrário do alheio, que pertence a outra atividade que não aquela que o agente está atualmente realizando (EN X 5, 1175b21-22). 
Em segundo lugar, não poderíamos dizer que o sentido de teleiồ é completar, pois a atividade, como vimos, é uma atualização completa, um todo completo indivisível, cujo fim é ela mesma; por isso, ela não poderia ser completada pelo prazer, ou seja, a realização da natureza da atividade não depende do prazer para se completar. Assim, se o prazer é capaz de aperfeiçoar a atividade, é porque ela deve possuir uma natureza aperfeiçoável. Sabemos que toda atividade cognitiva é aperfeiçoável; pois podemos perceber e pensar com mais discernimento se tivermos prazer em conhecer. Certamente temos prazer em conhecer, uma vez que o desejo de conhecer nos é natural e isto nos diz o filósofo no célebre início da Metafísica: “Todos os homens, por natureza, desejam conhecer. Uma indicação disto é o prazer que temos com os nossos sentidos” (Met. I 1: 980a21-3). Dizer que o prazer próprio ou apropriado ao conhecimento aperfeiçoa a atividade cognitiva significa dizer que, ao estarmos exercitando prazerosamente a atividade de conhecer, o prazer sobrevém como uma perfeição por acréscimo que nos faz conhecer mais e melhor, isto é, de modo perfeito. Que fique claro que ter prazer não aperfeiçoa a capacidade cognitiva no sentido de produzir aquisição de conhecimento. Ou seja, não é porque estamos tendo prazer que nós adquirimos conhecimento, mas, ao contrário: é porque estamos adquirindo conhecimento que nós sentimos prazer. Por isso, o prazer, em hipótese alguma, pode ser responsável pela aquisição de conhecimento. O que ele faz é favorecer tal aquisição. E favorece na medida em que altera o estado daquele que conhece, isto é, aquele que conhece com prazer tem mais discernimento, mais concentração, mais acuidade e, portanto, mais capacidade de prolongar-se na realização da atividade cognitiva no decorrer do processo de aprendizado, ou seja, de dedicar mais tempo aos estudos.

$\mathrm{O}$ ato mesmo de ver não é e não pode ser aperfeiçoado. Ele é completo imediatamente, tal qual a natureza do prazer, como vimos. Mas a visão que serve ao conhecimento, ou seja, a percepção enquanto atividade cognitiva auxiliadora da aquisição de conhecimento pode ser aperfeiçoada. Em suma, devemos entender aqui percepção não como o ato simples de perceber, como a passividade de ser afetado pelo objeto sensível, mas enquanto uma atividade que, em conjunção com o pensamento, exerce função cognitiva. Não pretendemos nos aprofundar na questão do aperfeiçoamento enquanto um desenvolvimento da própria natureza, tal como foi formulada no De Anima II, $5 .{ }^{83}$

83 Sobre este ponto, ver também Burnyeat (2002) e Aggio (2006) O que é percepção segundo Aristóteles em "Conhecimento perceptivo segundo Aristóteles", dissertação de mestrado apresentada 
Queremos apenas ressaltar a possibilidade das faculdades cognitivas, perceptiva e intelectiva, serem aperfeiçoadas. Por isso, a percepção deve ser entendida de duas maneiras neste contexto: como afecção receptiva e como atividade cognitiva. Ambos são paradigmáticos: o ato de perceber é paradigmático para a compreensão da natureza do prazer enquanto um todo imediatamente completo (1174a15-16) e a atividade perceptiva discriminativa (1175a1-2) para a compreensão de atividade realizada perfeitamente. Em termos gerais, toda atividade cognitiva é completa enquanto atualização imediata de sua forma e aperfeiçoável enquanto uma atividade que pode atingir o máximo de sua excelência, a saber, conhecer maximamente.

Uma vez tendo mostrado que a atividade pode ser aperfeiçoada, devemos entender quais atividades e como elas podem ser aperfeiçoadas. Quanto ao tipo de atividade, Aristóteles nos diz que é aquela em que o objeto e a faculdade se encontram em bom estado. Com efeito, o prazer não é necessário para que ocorram as boas condições de realização da atividade, mas é necessário para que tal realização seja perfeita, pois, ao termos prazer, a realizamos com mais empenho. Tendo prazer, desejamos mais fazer o que estamos fazer e, neste sentido, o prazer é um efeito da atividade que retroage sobre ela revigorando-a, tornando-a perfeita em sua realização.

A condição adequada necessária e suficiente para que a atividade se realize, mesmo que não perfeitamente, é a excelência da faculdade e de seu objeto. Uma vez que haja excelência tanto no objeto como no sujeito e estes se encontram, então necessariamente decorrerá o prazer (1174b31). Como disse, a causa que faz com que a atividade seja bem realizada é que ambos, faculdade e objeto, estejam em condições adequadas. Quanto melhor for tal realização, mais prazerosa será realizá-la, e quando mais prazerosa, mais perfeita será a atividade.

Em suma, o aperfeiçoamento ocorre na medida em que o agente, ao estar realizando a atividade com prazer, realiza-a com mais discernimento (krinousi) e exatidão (akribeia), fazendo com que ela seja mais exata (exakribô̂), mais bem feita (beltious poiê̂) e mais prolongada (chroniôteras) (1175a30-b16). O argumento inicia-se com essa constatação empírica, a saber: os efeitos benéficos do prazer sobre a realização da atividade. Antes de prosseguirmos, vale a pena reiterar a seguinte ressalva: a atividade não é bem realizada por causa do prazer 
que lhe acompanha, mas por causa das condições maximamente adequadas em que se encontram tanto o agente quanto o objeto de sua ação (seja o objeto noético ou sensível). A lógica é inversa do que comumente se pressupõe, ou seja, não é por ser prazerosa que realizamos bem a atividade, mas por a realizarmos bem é que a atividade é prazerosa. Nas palavras do filósofo: "na medida em que ambos o objeto inteligível (noêton) ou perceptível (aisthêton) e a discriminação (to krinon) ou contemplação (theoroun) são como se deve, haverá prazer na atividade" (1174b36-1175a2). Mais claramente, a boa realização da atividade é a causa do prazer e o prazer, consequentemente, aperfeiçoa a sua realização, "pois não há prazer sem atividade; e o prazer aperfeiçoa toda atividade” (1175a21-22). Se Aristóteles pensasse o contrário, a realização da atividade seria boa por ser prazerosa e não prazerosa por ser boa. Com efeito, a realização é perfeita se e somente se é prazerosa.

Vimos até o momento que tipo de atividade pode ser aperfeiçoada pelo prazer, a saber, a boa atividade no sentido de bem realizada. Cabe fazermos a seguinte ressalva: dizemos que a atividade é boa não no sentido moral, mas técnico, isto é, a boa atividade é a atividade bem feita ou bem realizada, que, por sua vez, torna-se perfeita por ser perfeitamente realizada; neste último caso, ela necessariamente é feita com prazer. Com efeito, Aristóteles não forneceu, até o momento, nenhum exemplo de atividade moral. Em seguida, devemos procurar compreender como ocorre tal aperfeiçoamento, pois não será do mesmo modo em que a faculdade e seu respectivo objeto, quando em boas condições, aperfeiçoam a atividade (1174b24-25). ${ }^{84}$ Para explicar essa questão, o filósofo lança mão da seguinte comparação: a saúde e o médico não são causas da cura do mesmo modo que o prazer e a faculdade/objeto o são da atividade perfeita (1174b26). Dessa comparação, podemos interpretar que o prazer é antes como a saúde que vem adquirindo o convalescente do que a ação médica ${ }^{85}$ Para ser curado, o paciente deve estar com o seu organismo em condições adequadas para receber o tratamento e o tratamento também deve ser tal que seja adequado para aquele

84 Esta questão, devido à sua complexidade, será retomada mais adiante, na seção do próximo capítulo: "Problema I: a função do prazer".

85 Stewart (1892, ad loc.), interpreta a comparação da mesma maneira, porém, assim como a saúde é a causa formal e a ação médica a eficiente, o prazer seria a causa formal da perfeição da atividade, enquanto a faculdade e o objeto seriam a causa eficiente. Como veremos adiante, não parece ser adequado compreender o prazer como causa formal ou final. 
paciente em particular. Eis as duas condições essenciais para a cura: o organismo do paciente e o tratamento médico. Ou seja, o paciente e a ação médica devem estar em boas condições para que ocorra bem a cura, assim como a faculdade e seu respectivo objeto devem estar em boas condições para que ocorra bem a atividade. Se o paciente, que ainda for curável, receber o tratamento adequado, provavelmente se seguirá a cura. Todavia, para que a cura se realize da melhor maneira possível, o paciente deve ir adquirindo saúde durante o processo: este parece ser o acréscimo estimado para que a cura seja perfeita. Da mesma maneira, o prazer que o agente sente enquanto está agindo é o acréscimo necessário para que a atividade seja realizada perfeitamente ou da melhor maneira possível.

Em resumo, temos o seguinte quadro: a primeira condição consiste no tratamento adequado e na reação adequada do paciente, o que equivale à atualização adequada da faculdade pelo seu respectivo objeto em circunstâncias favoráveis. Sem essa condição essencial, não há cura; analogamente, não há uma boa percepção. Contudo, o ideal é que o paciente passe a adquirir saúde durante a convalescença, pois isso potencializará a própria cura, no sentido de que assim o paciente reagirá melhor ao tratamento e convalescerá mais rapidamente ou do melhor modo possível. Do mesmo modo, o percipiente que tem prazer durante a discriminação perceptiva otimiza a sua execução, isto é, percebe melhor e com mais acuidade. Enfim, ao estar sendo curado, o paciente vai retomando a sua saúde, e ao ir retomando a sua saúde, mais perfeitamente ele será curado. Em analogia, ao estar realizando certa atividade em condições adequadas, o agente sente prazer e, ao estar sentindo prazer, mais perfeitamente ele executa tal atividade.

Desse modo, o prazer aperfeiçoa não como uma disposição inerente (hêxis enuparchousa) ao agente, mas como uma perfeição (telos) por acréscimo (epigignomenon) à boa realização da atividade (1174b31-32). Por isso, o prazer pode ser compreendido como uma espécie de epifenômeno da atividade, isto é, um fenômeno que sobrevém ou que se segue como um efeito à realização da atividade. ${ }^{86}$ Ele é a pedra de toque para a boa atividade, como a flor da idade o é para

86 Também em EN II 3, Aristóteles diz que "nós devemos tomar como um sinal (sêmeion) das disposições o prazer e a dor que sobrevêm (epiginomenên) aos atos" (1104b3). O particípio epiginomenên deriva-se do verbo epigignomai, que significa nascer depois, vir depois, posteriormente ou em seguida; e que em latim se traduz por supervenire. Por isso, o prazer parece ser compreendido como uma espécie de epifenômeno da atividade. 
a juventude (hoion tô̂s akmaiois hê hôra). ${ }^{87}$ A metáfora "flor da idade" se aproxima do que entendemos por "apogeu da primavera" e pode ser interpretada do seguinte modo: se o prazer está para o apogeu, a atividade está para a primavera. Ora, quando algo bom, como a primavera ou a juventude, está em seu melhor momento ou estágio de perfeição, dizemos: “Eis o apogeu da primavera!” Do mesmo modo, a perfeição é como o apogeu da boa atividade, por isso, no que diz respeito à atividade virtuosa, a sua perfeição é quando ela é realizada virtuosamente, isto é, por alguém que seja virtuoso e que sinta prazer em realizá-la em vista dela mesma.

Compreender o prazer como uma perfeição que sobrevém (epigignomenon ti telos $)^{88}$ à boa atividade significa, por um lado, minimizar o efeito do prazer sobre as ações, mas, por outro, significa não relegá-lo ao mero estatuto de contingente. Ele não é um mero contingente, pois a sua regularidade é fruto de uma relação necessária entre causa e efeito, a saber: no mais das vezes, o agente sente prazer quando faz uma ação em condições adequadas. É apenas quando se realiza bem uma ação que o prazer pode sobrevir. Isso significa pressupor que o prazer não existe em separado da boa realização da atividade.

Até o momento, vimos que a definição de prazer como uma perfeição que sobrevém e aperfeiçoa a própria atividade à qual pertence nos permite inferir que a qualidade moral do prazer depende da qualidade moral desta atividade à qual ele pertence. Essa inferência, por sua vez, não é tão clara assim como gostaríamos. Neste capítulo 4, os exemplos para determinar o vínculo do prazer à atividade são sempre de atividades sensíveis ou noéticas. Apenas no capítulo 5, como veremos, com a tese da diferença específica entre os prazeres, Aristóteles fornece exemplos de atividades morais e faz o valor moral do prazer depender do valor atribuído à atividade à qual ele pertence. De qualquer maneira, parece

87 Cf. EN X 4: 1174b33-35. Os termos akmaiois e hôra são de difícil tradução. Ross e Broadie traduzem por "auge da juventude" (bloom of youth). Todavia, segundo Riel (2000, p. 57) e Gauthier (2002, ad loc.), a expressão "flor da idade" não se refere à juventude, mas ao vigor da idade, que comumente ocorre aos 30 anos quanto ao corpo e aos 45 quanto à alma (Ret. II 14: 1390b9-11).

88 Rowe (2002) e Ross (1980) traduzem telos por fim. Neste sentido, podemos dizer que Alexandre de Afrodisia afirma corretamente que o prazer é de certo modo o fim da atividade prazerosa (Problemas Éticos: Problema 2, 120, 11-16). As demais traduções costumam traduzi-lo por perfeição. Acredito que podemos entender de ambos os modos; mas nos é preferível perfeição, pois, certamente, telos pode significar preenchimento ou acabamento de algo, consumação, resultado, término, portanto, perfeição. Neste contexto, a própria função do prazer de aperfeiçoar a atividade, nos induz a conceber telos como uma perfeição que sobrevém à atividade prazerosa. 
ser evidente que tudo o que Aristóteles pretende é fazer com que a escolha e a fruição do prazer dependam da escolha e da realização da atividade. Isso porque, se fosse o contrário, se a escolha de nossas atividades dependesse do prazer que se lhe segue, certamente a sua ética seria utilitarista e radicalmente hedonista, o que está longe de ser verdadeiro.

Como o prazer é aquilo que acompanha (hepetai) a atividade, então ele não existe em si e por si mesmo, mas para ou segundo certa atividade. Assim, o penúltimo parágrafo do capítulo (1175a4-11) mostra que, em primeiro lugar, se ele existe apenas conforme a realização da atividade, então o prazer não pode ser contínuo, uma vez que a faculdade humana é incapaz de exercer qualquer atividade ininterruptamente. Em segundo lugar, o filósofo nos diz que a intensidade do prazer varia conforme a intensidade da atividade. Isso é evidente quando se trata de uma novidade, pois a atividade do pensamento é mais intensa diante de uma novidade; o mesmo ocorre com o prazer que a acompanha. Em suma, a duração e a intensidade do prazer variam conforme a duração e a intensidade da atividade (1175a4-10).

Ademais, como a atividade é condição necessária para o prazer existir e o prazer o é para a perfeição na execução da atividade, então é evidente que prazer e atividade estão unidos e são inseparáveis, pois o prazer é em absoluto inseparável da atividade; e a atividade, quando realizada perfeitamente, é inseparável do prazer (1175a20-22). Assim o filósofo conclui o capítulo dizendo que é inegável que todos desejam (oregesthai) o prazer, pois ele aperfeiçoa o próprio viver (1175a11-22). Esta é a conclusão que devemos esperar, visto que o prazer e a atividade são inseparáveis e que a vida são as várias atividades que realizamos. Evidentemente, dizer que o prazer aperfeiçoa tais atividades significa dizer que o prazer aperfeiçoa o nosso modo de viver. Como a vida é desejável e o prazer a aperfeiçoa, temos boas razões para buscá-lo. Por isso, é inegável que todos desejam o prazer, mas disso não decorre que a máxima hedonista de Eudoxo esteja correta, ou seja, que o prazer seja a finalidade da vida.

Apesar de a questão ter sido deixada em aberto - se buscamos (hairoumetha) a vida em vista do prazer ou o prazer em vista da vida -, Aristóteles claramente opta pela segunda alternativa, pois, como foi dito no primeiro livro da Ética Nicomaqueia (1097b1-7), o prazer é um bem que deve ser buscado em vista dele mesmo e também em vista do bem último, a finalidade da vida, o bem viver (eudaimonia). Assim, não devemos desejar a vida em vista do prazer, mas o prazer em vista da vida, ou seja, o prazer só deve ser desejado secundária e 
condicionalmente. Devemos buscar o prazer para viver melhor e não para ter prazer simplesmente. Quem deseja a vida em vista do prazer, pois vive em função dele, é o intemperante. Vale ressaltar que não se trata de buscá-lo acima do bem, mas conforme o bem; por isso, o temperante não busca qualquer prazer e nem a qualquer preço. Mesmo porque, como o prazer é obtido por meio da atividade, é ela que deve ser o objeto de desejo e não o prazer. ${ }^{89}$ Não podemos buscar o prazer por ele mesmo, senão como fruto de uma busca ilusória, de um engano. Afinal, não há prazer em absoluto. Há a sensação de prazer que acompanha a realização de certas atividades, como já vimos.

O capítulo 5, último capítulo do segundo Tratado do prazer, é dedicado a justificar e aprofundar a tese já apresentada em linhas gerais no capítulo anterior da diferença específica entre os prazeres (1175a22-1176a29). Tal tese se fundamenta na definição do prazer, tornando-a ainda mais evidente. Para defendê-la, Aristóteles fornece três argumentos.

A tese consiste em dizer que o que aperfeiçoa um tipo de atividade deve diferir em espécie do que aperfeiçoa outro tipo de atividade; logo, diferem os prazeres que aperfeiçoam as diferentes atividades (1175a22-28). O primeiro argumento diz que a evidência desta tese se apresenta pelo fato de coisas diferentes em espécie serem aperfeiçoadas por coisas também distintas, "como as coisas naturais e os produtos das artes, como os animais, as árvores, a pintura, a estátua, a casa, um móvel” (1175a23-25). Assim também diferem as atividades produtivas das atividades naturais e, como sabemos, das atividades morais; portanto, os prazeres que aperfeiçoam cada tipo de atividade também diferirão. Vê-se que este primeiro argumento se sustenta no fato de o prazer ser definido como aperfeiçoador da atividade.

O segundo argumento consiste em dizer que se a atividade é intensificada pelo prazer, então ele deve pertencer (oikeîa) a esta atividade; logo, se os prazeres pertencem a atividades que diferem em espécie, então eles também devem diferir em espécie (1175a29-b1). É de se notar que este segundo argumento se fundamenta na definição do prazer como próprio (oikeîa) à atividade. Ademais, dizer que a atividade é intensificada pelo prazer nada mais é do que dizer com mais clareza que ela é, desta maneira, aperfeiçoada pelo prazer. Os exemplos são de atividades teóricas, como o estudo de geometria e as atividades produtivas, 
como a música e a arquitetura, pois aquele que as realiza com prazer progride em sua função (1175a35), já que elas são intensificadas pelo prazer.

O terceiro argumento afirma a diferença entre os prazeres ao distinguir os que são próprios dos que não são, ou seja, o prazer sempre pertence à atividade que ele aperfeiçoa, pois a atividade é intensificada por um prazer que lhe é próprio e impedida por aquele que lhe é alheio (1175b2-24). O exemplo fornecido é o de um amante de flauta que se distrai na conversa quando escuta alguém tocando, pois não consegue mais prestar atenção nos argumentos, já que ele gosta mais de música do que da atividade que está atualmente realizando. Assim, quando fazemos duas atividades distintas ao mesmo tempo, a mais prazerosa suprime a outra. Por isso, diz Aristóteles, "quando nós gostamos muito de algo, dificilmente podemos fazer outra coisa” (1175b10). Desse modo, devemos compreender os prazeres alheios à atual atividade como impedidores que produzem um efeito parecido com a dor própria da atividade, diferenciando-se apenas em grau, pois ambos, a dor própria e o prazer alheio, suprimem a atividade, mas de maneiras distintas. Ou seja, enquanto a dor é essencialmente capaz de suprimir a atividade correspondente, o prazer alheio a suprime por concomitância, isto é, apenas por estar sendo sentido, ao acompanhar outra atividade, em concomitância com a atividade que está sendo suprimida. O prazer próprio, ao contrário, aperfeiçoa a atividade, fazendo com que ela seja mais precisa (exakriboi), mais bem feita (beltious poiê̂) e mais prolongada (chroniôteras) (1175b15-16). Nas palavras do filósofo: "A atividade, portanto, sofre efeitos contrários pelo prazer e a dor que lhe pertencem” (1175b21). O prazer aperfeiçoa a atividade, a dor a suprime. Desse modo, é evidente que os prazeres se distinguem em espécies conforme as atividades que eles acompanham. ${ }^{90} \mathrm{Com}$ estes três argumentos descritos acima, Aristóteles demonstra a sua tese da diferença específica entre os prazeres.

No fim do capítulo, uma vez tendo demonstrado que os prazeres diferem em espécie, Aristóteles passa a distingui-los conforme cada tipo de atividade (1175b25-1176a29). Tomemos as cinco distinções estabelecidas: (i) entre prazeres próprios e alheios à atividade que está sendo realizada, (ii) entre bons e maus (os bons são os que acompanham as boas atividades e os maus, as más), (iii) entre os mais e os menos puros (do inteligível ao sensível mais inferior), (iv)

90 Como diz Alexandre de Afrodisia (Problema 13, 133, 28-29), "pois se os prazeres fossem os mesmos, não seria o caso de um intensificar certa atividade e outro outra". 
os prazeres próprios de cada espécie animal (aqueles que acompanham as atividades da função própria (ergon) de cada espécie) diferem conforme a espécie e (v) os prazeres humanos em superiores e inferiores.

A distinção mais apropriada ao campo moral é aquela entre prazeres bons e maus, pois, se as atividades diferem segundo o seu valor moral, sendo umas boas (epieikeiai), outras más (phaulotêti) e algumas neutras (oudeterôn) ${ }^{91}$, então as primeiras devem ser escolhidas e as segundas, evitadas (1175b25-34). Assim sendo, conclui o filósofo, "o prazer de uma boa (spoudaiai) atividade é moralmente bom (epikeikês), aquele da má (phaulêi) atividade é moralmente mau (mochthêra)" (1175b28). Ou seja, como cada atividade tem seu prazer próprio, devemos admitir que seja realmente possível sentir prazer agindo de modo vil. Em suma, o prazer é bom quando acompanha uma atividade boa, e mau quando acompanha uma atividade má. Ademais, o prazer, sendo um próprio da atividade, não existe nem lógica nem ontologicamente em separado da atividade, o que se verifica pela tese da diferença específica dos prazeres. Ontologicamente, pois não há prazer sem atividade (1175a21); e, logicamente, pois não está nem no tempo, nem por natureza separado da atividade, ao contrário do desejo. De todo modo, ao concluir o parágrafo, o filósofo nos diz que, mesmo sendo estreitamente unidos, seria absurdo confundir o prazer com a atividade à qual ele pertence (1175b30-34).

Podemos concluir do que foi dito, que não há definição do valor moral do prazer senão a partir do valor moral atribuído à atividade A partir desse argumento, não se poderia mais sustentar a máxima eudoxiana de que o prazer é um bem em absoluto, nem a máxima espeusipiana de que ele é um mal em absoluto. Aristóteles parece se mostrar, portanto, avesso a uma interpretação essencialista do valor moral do prazer. Afinal, com a tese da diferença qualitativa entre os prazeres e a sua definição como sendo absolutamente dependente da atividade à qual acompanha, faz-se evidente que a qualidade moral do prazer depende da

91 Segundo Tomás de Aquino (1993, §2050), as neutras ainda não estão na categoria da bondade ou da maldade, mas podem passar a estar. Aristóteles nada nos diz sobre o que seriam atividades neutras, mas podemos supor que o mesmo consideraria as atividades das crianças, que ainda não são propriamente morais e que não podem ser responsabilizadas na mesma medida que um adulto. No caso dos adultos, as atividades produtivas e teóricas não seriam per se morais, embora possam também ser morais, a depender da intenção daquele que produz um objeto técnico ou teórico, pois, se esta for moral, tal objeto estaria a serviço de uma ação moral. Todavia, não podemos dizer que a atividade produtiva ou teórica é essencialmente moral, embora possa assim ser por acidente ou concomitância. 
qualidade moral da atividade à qual pertence, e o valor da atividade, por sua vez, depende do bom julgamento do agente moral.

Já a distinção entre graus de pureza do prazer pode ser compreendida a partir do grau de pureza do objeto ao qual se direciona a atividade (1175b35-1176a3). Aristóteles não nos fornece o porquê desta constatação, mas podemos supor, a partir do segundo livro do De Anima, que quanto maior a capacidade de apreender a forma sensível sem a matéria, mais puro é o sentido, e, consequentemente, o prazer que dele decorre; sendo o mais puro dos sentidos o da visão, em seguida, o da audição e o do olfato e, por último, o do tato e o do gosto. Assim, se compararmos os prazeres sensíveis e os inteligíveis, Aristóteles nos diz que são mais puros os inteligíveis e menos os sensíveis, pois estes últimos envolvem mais a matéria, isto é, o corpo do percipiente e o do percebido.

Quanto à distinção dos prazeres conforme a função própria ${ }^{92}$ de cada espécie, parece ser evidente que o prazer pode ser distinto, uma vez que é distinta a atividade que exerce a função própria de cada espécie (1176a4-29). Todavia, cabe fazermos a seguinte ressalva: em geral, por pertencerem a uma mesma espécie, os homens possuem prazeres em comum, porém, há também uma variedade de prazeres conforme as atividades que cada indivíduo realiza, já que "as mesmas coisas agradam uns e desagradam outros, e são penosas e odiosas para uns e prazerosas e amáveis para outros" (1176a11-12). Diante de tal variedade, Aristóteles estabelece que o critério qualitativo de distinção é o que o homem bom sente, pois,

Em todos esses casos, é-se da opinião que o que aparece ao virtuoso (to phainomenon tôi spoudaiôi) é o que é bom. E, se isto está correto como parece estar, a virtude e o homem bom enquanto tais são a medida ( $m e$ tron) de cada coisa. Portanto, as coisas que lhe aparecerem prazerosas são prazerosas e agradável é aquilo com o qual ele se deleita (1176a16-19).

Como foi dito, a medida de todas as coisas é a virtude e o homem bom qua bom. Ou seja, o homem bom é o critério para o que é prazeroso e penoso, pois seus prazeres são realmente ou por natureza prazerosos, isto é, são aqueles que acompanham as atividades que realizam a função própria do homem: a sua racionalidade. Logo, o que é considerado penoso para o homem bom, mas prazeroso 
para alguns, assim o é por corrupções (phthorai) e por doenças (lumai), ou seja, por debilidade natural ou moral, como já foi dito no primeiro Tratado. Enfim,

Tais coisas não são realmente prazerosas, mas o são apenas para certas pessoas e nas condições em que se encontram. É evidente, portanto, que aqueles que são admitidamente vergonhosos (aischras) não deveriam ser ditos prazer, a não ser para os perversos (diephtharmenois) (1176a22-24).

Isso significa dizer que o homem vil sente prazer com o que não é naturalmente prazeroso, todavia, não deixa de senti-lo. Porém, os prazeres próprios dos homens depravados são prazeres em um sentido secundário ou inferior, como foi dito no primeiro Tratado, eles são antinaturais ou contrários à nossa natureza; enquanto os do homem bom são prazeres superiores, pois são prazeres propriamente humanos, conforme a nossa natureza, ou seja, conforme a função própria do homem. Há, portanto, uma diferença de grau de qualidade entre os prazeres no caso do ser humano: o virtuoso sentiria prazeres superiores, propriamente humanos, enquanto o vicioso sentiria prazeres inferiores ou contrários à natureza humana.

Quanto à análise do segundo Tratado, podemos concluir que Aristóteles se preocupa menos em refutar o anti-hedonismo, como o fez no primeiro Tratado; por isso, a definição de prazer parece ser menos dependente da argumentação refutativa do que antes. Neste sentido, podemos inferir que a definição do prazer como uma atividade se constitui primordialmente em negação à definição platônica do prazer como um processo de geração ou movimento. Com essa refutação, abre-se a possibilidade de o prazer ser dito um bem. Já a definição do prazer como uma atividade sensível que aperfeiçoa a atividade à qual ele pertence, portanto, como sendo distinto da própria atividade que é prazerosa, permite que se possa estabelecer, com mais clareza, os critérios de valoração moral dos prazeres. A possibilidade de o prazer ser um bem, neste momento, é garantida pela natureza do prazer ser um todo completo, ao contrário do movimento, cuja natureza é inacabada.

\section{Análise comparativa dos dois Tratados do prazer}

Após termos feito a análise dos dois Tratados, parece ser natural apontarmos, em grandes linhas, as congruências e as divergências entre eles, de modo que fique mais clara a problemática tratada em cada um. 
O segundo Tratado do prazer é composto pelo livro X, do primeiro ao quinto capítulo (1172a19-1176a29). A primeira pergunta que poderíamos fazer é por que Aristóteles escreveu este segundo Tratado que, à primeira vista, não parece fazer qualquer referência explícita ao primeiro. As respostas dos intérpretes variam enormemente, mas, em geral, a maior parte ${ }^{93}$ diz que este segundo Tratado é mais propriamente aristotélico e, portanto, mais refinado filosoficamente; enquanto o primeiro, por fazer parte dos livros comuns às Ética Eudêmia e Ética Nicomaqueia, seria de um Aristóteles mais imaturo, ainda muito influenciado por Platão. De fato, a diferença entre os Tratados é considerável se tomarmos a definição do próprio objeto, o prazer, e verificarmos o quanto são distintas, mas há uma semelhança considerável: em ambos o prazer é dito ser uma atividade (energeia). Enquanto no primeiro, o prazer é simplesmente uma atividade, no segundo, ele é uma atividade que acompanha e aperfeiçoa outra atividade. Todavia, podemos supor que não há uma separação surda entre os Tratados e que, no segundo Tratado, Aristóteles revisaria e redefiniria com maior exatidão a noção de prazer, sem deixar de aproveitar os ganhos conceituais obtidos no primeiro Tratado.

Quanto a esta aparente inconsistência entre os Tratados, Owen ${ }^{94}$ nos fornece uma solução engenhosa, a saber, que eles divergem por tratarem de questões distintas e, por divergirem em seus propósitos investigativos, ao serem comparados, não podem ser considerados inconsistentes. Segundo este autor, a pergunta sobre o que é o prazer, própria do primeiro Tratado, é distinta da pergunta do segundo sobre o que é “ter prazer", portanto, os Tratados não são contraditórios se cotejarmos suas respostas, uma vez que elas serão distintas na medida em que respondem a perguntas distintas. Ou seja, elas são coerentemente distintas.

Segundo Gosling e Taylor, ${ }^{95}$ os Tratados são díspares também por responderem a questões distintas, porém não às mesmas que estipula Owen: no primeiro, a pergunta é sobre se algum prazer é o bem e, no segundo, a pergunta é se o prazer é o bem. Diferentemente dos dois comentadores citados acima, Tomás

93 Como, por exemplo, Festugière (1946), Gauthier (2002), Owen (1986, p. 180-99) e Zingano (2007a, p. 297-330).

94 OWEN, 1965.

95 GOSLING; TAYLOR, 1982. 
de Aquino ${ }^{96}$ diz que a diferença entre o primeiro e o segundo é que o primeiro trata, sobretudo, dos prazeres corporais e o segundo trata do prazer enquanto um acréscimo à felicidade.

O ponto é que, a meu ver, não há duas perguntas diferentes. As perguntas são as mesmas: o que é o prazer e sob quais critérios ele seria um bem. Todavia, mesmo tratando das mesmas perguntas, as definições de prazer divergem essencialmente e isso é inegável. Se, no primeiro Tratado, o filósofo identifica o prazer com a atividade com vistas a refutar a concepção platônica de que o prazer é um movimento e não o fim do movimento, assim ele procede para garantir a possibilidade de que o prazer possa ser considerado um bem. O problema é que esta definição nos garante a possibilidade do prazer ser um bem, mas não nos fornece os exatos critérios para a valoração moral do prazer. Isso porque o único critério fornecido brevemente e sem desdobramentos posteriores é de que a qualidade moral do prazer depende da retitude de seu objeto e do modo moderado de desejá-lo, portanto, da retitude do caráter do agente. Digo brevemente, pois o filósofo não nos diz como se justificaria esta dependência, fundamentando a própria necessidade destes critérios.

Já no segundo Tratado, visto que a atividade é distinta do prazer, ela pode ser o objeto de julgamento do agente moral e não o prazer. Ou seja, a ação moral sobre a qual o agente é inteiramente responsável passa a ser determinante na qualificação do valor moral do prazer. Na verdade, com este segundo tratado, fica evidente a relação entre o bom objeto e o bom desejo para se obter o bom prazer. Se ter prazer nada mais é do que ter prazer com certa atividade, o objeto do prazer é a atividade. Assim, desejar ter prazer é desejar realizar certa atividade considerada prazerosa. Logo, o bom desejo incide sobre o bom objeto, isto é, a boa atividade e o bom prazer decorre da realização da boa atividade. Isso significa que o critério para o prazer ser bom é a boa atividade. E o critério para a boa atividade é o bom caráter, ou seja, razão e desejo retos. Evidentemente, se a ação for correta, ela incidirá sobre o objeto prazeroso correto e o agente saberá desejá-lo na justa medida.

Ademais, a definição do primeiro Tratado suscita a possibilidade de o prazer ser identificado ao bem supremo, já que ele é concebido como uma atividade desimpedida e a felicidade, por ser perfeita, também é necessariamente uma 
atividade desimpedida. Vimos, porém, que conceber tal possibilidade hipotética não é senão a título argumentativo, reforçar a refutação, e não de fato assumir a tese hedonista de que o prazer realmente seja o bem supremo. ${ }^{97}$

Em suma, as definições divergem, pois os propósitos divergem. Aristóteles, no primeiro Tratado, parece querer provar que o prazer possa ser certo bem, e assim o fez identificando prazer e atividade. Já no segundo Tratado, ele pretende distinguir prazer e atividade prazerosa de modo a evitar a possível identidade entre prazer e felicidade, o que lhe obriga a fornecer com maior precisão os critérios de avaliação da natureza moral do prazer. Sendo assim, como o prazer é uma perfeição que sobrevém à atividade que ele pertence, a sua natureza e existência dependem inteiramente da natureza e da existência da atividade. Portanto, com esta nova definição, podemos compreender mais claramente que o prazer é distinto da atividade prazerosa e não poderia ser identificado à melhor e mais prazerosa atividade: a felicidade. Do mesmo modo, a qualidade moral do prazer será concebida conforme a qualidade moral da atividade à qual ele pertence e a sua função moral será a de poder aperfeiçoá-la. Vemos que a definição do segundo Tratado é nitidamente mais sofisticada e mais relevante para a armadura conceitual da ética.

Além dos propósitos e das definições serem distintos, evidentemente, também serão os caminhos argumentativos. No primeiro Tratado, Aristóteles faz uso de argumentos de Eudoxo, se aproximando assim do extremo hedonismo com vistas a refutar o anti-hedonismo de Platão e de Espeusipo, e, com essa estratégia refutativa, a única tese propositiva que ele formula é a de que o prazer pode ser um bem. Já no segundo Tratado, Aristóteles passa a criar as bases para sustentar o seu hedonismo moderado, distanciando-se, portanto, do radicalismo hedonista de Eudoxo ao mostrar que ele é, em parte, falso e, em parte, verdadeiro. A pergunta que se coloca é se o prazer pode ser o bem ou o mal em absoluto e a resposta, a partir da definição de prazer como um próprio da atividade, é negativa, pois ele deve depender da atividade para ganhar algum atributo moral.

É plausível, a meu ver, supor que, por causa da necessidade de se provar que o prazer é um bem, o filósofo teve que identificá-lo tout court à atividade, o que gerou a possível identificação com a felicidade. Como, evidentemente, 
Aristóteles não assumiria tal identificação, própria de um hedonismo exagerado, surge a necessidade de provar que o prazer não é a felicidade, mas é condição necessária para tanto. Sendo assim, podemos supor que a investigação do segundo Tratado é motivada por uma dificuldade posta pelo primeiro, o que parece indicar o vínculo lógico entre ambos os Tratados.

Ademais, o problema do primeiro Tratado de identificar prazer e atividade não se traduz apenas em ter que decidir se a felicidade consistiria em alguns prazeres ou em uma classe de prazeres, como argumenta Owen..$^{98}$ Os problemas que se sucederiam, a meu ver, seriam dois. O primeiro seria suscitar uma possível identificação inapropriada entre felicidade e prazer. O segundo seria cometer uma contradição lógica, que Aristóteles mesmo salienta no segundo Tratado, a saber: a identificação entre duas atividades de natureza distintas que, portanto, não podem ser coextensivas: a atividade perceptiva ou intelectiva e a atividade de sentir prazer. Ou seja, não se pode, sob pena de cair em contradição, identificar perceber ou pensar e ter prazer. Por isso, o coração da argumentação do segundo Tratado se encontra na tese de que o prazer e a atividade são inseparáveis, todavia, distintos. O prazer é uma atividade sensível que depende de outra atividade para existir, pois sentimos prazer (atividade 2) ao realizarmos certa atividade (atividade 1), como ver o pôr do sol, desvendar um problema de matemática, ser generoso com seu amigo, produzir uma bela música etc. A atividade 2 depende lógica e ontologicamente da atividade 1.

Deve-se, portanto, abandonar a definição de que o prazer é simplesmente uma atividade desimpedida conforme a nossa natureza. Ora, as atividades perceptiva e intelectiva são desimpedidas e conforme a nossa natureza quando a faculdade e objeto se encontram em boas condições, mas não são, elas mesmas, o próprio prazer que delas decorre. Mesmo que o prazer possa ser dito um tipo de atividade (energeia), enquanto atualização completa, ainda assim, ele não pode ser identificado ao perceber e ao pensar, que são atividades (energeiai) de outro tipo, de outra natureza, portanto, com definição distinta. Ter prazer não pode ser confundido com a própria apreensão da faculdade perceptiva de certo objeto sensível ou com a própria apreensão da faculdade intelectiva de certo objeto noético. Logo, o problema não estaria em ter de determinar qual prazer seria o 
bem supremo, mas de assumir a contradição oriunda da identificação tout court entre prazer e atividade. Nas palavras do filósofo:

O desejo é, tanto no tempo como por natureza, distinto da atividade; já o prazer é extremamente vinculado à atividade, de fato tão inseparável da atividade, que surge a dúvida se o prazer e a atividade ${ }^{99}$ não são a mesma coisa. Contudo, não devemos considerar que o prazer seja realmente uma sensação ou um pensamento, pois isso é absurdo; embora sejam inseparáveis, a alguns parece o mesmo (EN X 5: 1175b30-36).

Fica claro, pois, que, no segundo Tratado, o prazer é distinto da atividade à qual ele acompanha, ainda que seja ontologicamente inseparável, ou seja, a sensação ou o pensamento são distintos do prazer, mas podem vir acompanhados dele.

Por fim, a distinção entre os dois Tratados incide na definição de prazer, no propósito desta definição, bem como na trajetória argumentativa para obtê-la. Porém, apesar dessa diferença, há um vínculo lógico entre os Tratados, pois o segundo pretende resolver a possível e problemática identidade entre prazer e bem supremo legada pelo primeiro Tratado. Com efeito, alguns ganhos conceituais do primeiro são preservados e retomados no segundo Tratado, como (i) a refutação da concepção platônica de que o prazer não seria um bem por ser um processo sensível; (ii) a refutação da concepção de Espeusipo de que o prazer é em absoluto o mal; (iii) a distinção entre prazer natural e antinatural ou excessivo; (iv) a concepção de prazer por acidente; (v) a tese de que os prazeres próprios do pensar não o impedem, mas apenas os prazeres alheios; ao contrário, eles nos fazem pensar e aprender mais. Dizer, em VII 12 (1153a22), que os prazeres próprios do pensamento nos fazem pensar e aprender mais já é um prenúncio da definição de prazer do segundo Tratado como aquilo que é capaz de aperfeiçoar a atividade. Com efeito, a distinção entre prazer próprio e prazer alheio à atividade também será retomada no segundo Tratado, em X 5 (1175a30-b33). Por fim, o principal atributo da definição de prazer será retomado: o de que ele é uma atividade, um todo completo, portanto, de que ele não é um movimento, um todo incompleto. A diferença é que o prazer será uma

99 É preciso enfatizar que, neste momento, Aristóteles está se referindo à atividade de perceber ou de pensar, portanto, não se trataria de negar que o prazer seja uma atividade em termos absolutos, mas que ele não seja a atividade que ele acompanha. 
atividade absolutamente dependente de outra, seja esta cognitiva, produtiva, artística ou moral. O tipo de prazer dependerá do tipo de atividade que gera o prazer e o tipo de atividade dependerá daquele que a realiza. Podemos concluir que não apenas há compartilhamento de certos conceitos, como o segundo Tratado resolve o problema da identificação entre prazer e felicidade legado pelo primeiro Tratado, o que desfavorece a interpretação de que não haveria continuidade alguma entre os dois Tratados. 


\section{Interpretação dos problemas}

\section{Problema I: A função do prazer}

Como o prazer é um efeito que retroage à sua causa, a atividade, e, ao retroagir, ele é capaz de causar certa perfeição da realização da atividade, seria válido recorrer à teoria das quatro causas para explicar o fenômeno do prazer, como fizeram, em geral, os comentadores? Se for válido proceder à análise fazendo uso da grelha conceitual das quatro causas, a título de esclarecimento, então o problema consiste em determinar o tipo de causa que o prazer exerce para que a atividade seja realizada de modo perfeito.

Parece-nos que o prazer não é aquilo em vista do qual uma atividade é aperfeiçoada, mas o que produz tal aperfeiçoamento, operando como causa eficiente não da natureza da atividade, mas do aperfeiçoamento de sua realização. Isso porque a causa de a atividade ter uma natureza completa (teleia) é o fato de a atividade ser, ela mesma, um todo completo cuja atualização de sua natureza ou forma (eîdos) é completa desde o instante em que surge. ${ }^{1}$ Isso significa que a forma da atividade não poderia ser aperfeiçoada ou completada ao longo do tempo. Tampouco o prazer é a causa de a atividade ser boa ou bem realizada. A causa, já nos disse Aristóteles em EN X 5, é a condição adequada da faculdade

1 Conforme já foi explicitado no segundo Tratado de prazer e analisado no primeiro capítulo deste livro: "Análise conceitual do prazer". 
e seu respectivo objeto. Esta adequação gera uma boa $^{2}$ atividade acompanhada de prazer, o qual, por sua vez, causa o aperfeiçoamento de sua execução. Em poucas palavras: o prazer é um efeito que torna a atividade perfeita em sua realização. A seguir, faremos a exposição das quatro causas envolvidas na constituição da atividade simplesmente e da perfeita atividade, fazendo uso, assim como o fez Aristóteles, da atividade perceptiva como paradigma. Contudo, é preciso antes distinguir três maneiras de ser causa da atividade: (i) é possível ser causa da atividade, (i) é possível ser causa da perfeita atividade, e (iii) é possível ser causa da realização perfeita da atividade. O que pretendo mostrar é que o prazer é causa da perfeita realização da atividade.

Quanto à causa formal da atividade, dizemos que é aquilo que faz com que a atividade seja uma atividade, portanto, aquilo que a define enquanto tal. Atividade (energeia), em termos gerais, é uma ação completa, isto é, a atualização de sua forma é completa (energeia teleia) desde o instante em que passou a existir. O prazer, certamente, não poderia ser a causa formal da atividade, pois ele não é aquilo que faz com que a forma da atividade seja completa desde sempre; mesmo porque uma atividade não deixa de ser atividade por não se prazerosa. Assim, a causa formal da percepção é ser capaz de receber a forma sensível sem a matéria.

Quanto à causa final da atividade, dizemos que é a sua própria realização, portanto, a própria realização de sua forma, ou seja: as causas formal e final da atividade coincidem, pois o fim da atividade é a própria realização de sua forma. Ora, não poderíamos dizer que o prazer é causa final da atividade. A atividade se caracteriza por ter o fim em si mesma, ao contrário do movimento cuja finalidade lhe é extrínseca. ${ }^{3}$ Assim, o fim primário ou essencial da atividade é a sua própria realização. É claro que o desejo pode estabelecer diversos outros fins para a realização desta ou daquela atividade, por exemplo, o fim de obter prazer. Podemos, sem dúvida, orientar a realização de certa atividade em vista do prazer subsequente; todavia, esta finalidade é secundária e acrescida por aquele que assim deseja. A finalidade primeira ou a natureza própria da atividade é simplesmente a sua realização. Denomino de fim primário quando a realização

2 Boa aqui não no sentido moral, mas técnico, isto é, realizada quando sujeito e objeto se encontram em condições adequadas.

3 A diferença entre movimento e atividade já foi explicitada na análise do segundo Tratado, feita no primeiro capítulo deste livro. 
da atividade é o seu próprio fim, e secundário quando a realização da atividade se faz em vista de um fim posto conforme o desejo particular daquele que age. Com efeito, a finalidade da atividade de perceber é simplesmente atualizar da melhor maneira possível a capacidade de receber a forma sensível sem a matéria. Por exemplo, contemplar o pôr do sol é primeiramente contemplar de modo perfeito e, secundariamente, se assim for o desejo de quem contempla, ter prazer com esta contemplação.

Quanto à causa material da atividade, dizemos que é o órgão materialmente capaz de apreender e o objeto materialmente capaz de ser apreendido pelo respectivo sentido, por exemplo, apenas a cor é materialmente perceptível pela visão. Quanto à causa eficiente desta atividade, sabemos que o objeto sensível atualiza sua respectiva faculdade, e assim engendra a atividade perceptiva. Se tal atividade for perfeita, então dizemos que a causa eficiente são a faculdade e o objeto quando estes se encontram em condições materiais adequadas, pois quanto em melhor estado estiver o objeto sensível e a sua respectiva faculdade, melhor será a percepção. Por exemplo, para que a perfeita visão ocorra, o percipiente deve enxergar bem e estar com os olhos em bom estado, assim como o objeto visível deve estar em boas condições, como nem muito longe ou perto, nem sob intensa ou débil luminosidade etc.

Todas essas causas expostas acima engendram a perfeita atividade, mas não a perfeita realização desta atividade. Assim, é preciso ter em mente a distinção entre (i) a realização da atividade, (ii) a realização da perfeita atividade e (iii) a realização perfeita da atividade. O prazer, assim nos parece, é causa eficiente da realização perfeita da atividade. Entendemos que o prazer não é causa da completude da natureza da atividade, mas da sua perfeita realização ou execução. Ou seja, executamos melhor, isto é, mais perfeitamente, quando temos prazer, pois desejamos mais realizar a atividade que atualmente estamos realizando. Por isso, acreditamos que se tivermos que fazer uso da teoria das quatro causas para explicar em que sentido o prazer é causa da perfeição da atividade, devemos pressupor, em primeiro lugar, como já foi dito, que ele é causa não da perfeição da atividade, mas da perfeição da realização da atividade, e, em segundo lugar, que o tipo de causa que expressa a ação do prazer sobre a realização da atividade é a eficiente. Em suma, o prazer não é causa de a atividade ser perfeita, mas é causa de sua perfeita realização.

Não constatamos que qualquer comentador fizesse a necessária distinção entre completar (teleiô̂) a natureza da atividade e aperfeiçoar (teleiô̂) a sua 
realização. Ora, de nenhum modo a natureza da atividade seria completada (teleiô̂) pelo prazer, visto que ela é completa (teleia) desde seu surgimento. Tampouco o prazer seria causa da perfeita atividade, isto é, da atividade realizada em condições perfeitas, ou seja, quando o agente e o paciente, a faculdade e o objeto encontram-se em condições adequadas ou as melhores possíveis. Se o prazer não poderia causar nem a completude (teleiô̂) da atividade nem a sua perfeição (teleia), então ele é tão somente causa da perfeição de sua realização. Sem estas distinções primárias, toda sorte de confusão é possível e qualquer interpretação parece ser válida.

De modo algum o prazer poderia ser o fim da natureza da atividade, nem de seu aperfeiçoamento ou completude, como afirmam alguns. Assim o faz Festugière, ${ }^{4}$ sobretudo porque o prazer foi definido como um fim (telos) que sobrevém. Porém, telos pode ser entendido como perfeição ou acabamento. Porém, para Festugière, o objeto sensível e a faculdade sensível são causas eficientes do fenômeno perceptível e o prazer, a causa formal e final, ou seja, o prazer é a causa final e formal em vista do qual a atividade é propriamente aperfeiçoada. Tal interpretação, por sua vez, nitidamente contradiz a tese de que o prazer é aquilo que é próprio à atividade e não a sua finalidade (causa final) ou identidade (causa formal). Em discordância com Festugière, Tomás de Aquino, Gauthier e Jolif, e Gosling e Taylor ${ }^{5}$ concebem o prazer antes como a causa formal do que a final, pois pensam que ele é antes a perfeição de uma atualização ou condição para tal perfeição do que o seu fim. O problema dessa interpretação é admitir a possibilidade de o prazer ser, ele próprio, a perfeição da atividade, pois ele não poderia ser outra coisa senão um tipo de causa da perfeição na execução. Riel expõe em detalhe a querela dos comentadores sobre o tipo de causa que seria o prazer, porém ele mesmo não opta por nenhuma das interpretações, dizendo apenas que "o prazer não é uma causa, já que ele é apenas um elemento superveniente". ${ }^{6}$

A meu ver, o fim da atividade é a sua boa realização. Ou seja, o prazer não pode ser a causa final nem da perfeita atividade, nem do aperfeiçoamento de sua execução, pois a finalidade da execução perfeita é a própria perfeição na

\footnotetext{
4 FESTUGIÈRE, 1946.

5 AQUINO, 1993, §2030; GAUTHIER, 2002; GOSLING; TAYLOR, 1982, cap. 13.

6 RIEL, 2000, p. 55-56, tradução minha.
} 
execução, ou seja, o aperfeiçoamento promovido pelo prazer serve para que a atividade seja executada do melhor modo possível. Em suma, sabemos que a atividade deve ser perfeita para que o prazer se siga em grau máximo. Ele é um efeito da atividade perfeita que, por sua vez, retroage revigorando sua causa. Afinal, ao retroagir, ele não poderia ser causa do que lhe causou; logo, ele é apenas causa de um revigoramento da execução e não da existência da atividade tal qual ela é. Neste ponto, concordamos com Riel, para o qual o prazer não é nenhum tipo de causa que faz com que a atividade seja perfeita. Como ele diz:

O prazer não pode ser estritamente considerado como uma causa final: ele não é o fim ao qual aspira a atividade. Claramente, não é sempre que nós realizamos todas as nossas atividades com vistas a obter prazer. $\mathrm{Pa}$ rece até mesmo ser o caso de que uma aspiração estritamente direcionada para obter prazer, na verdade, nos preveniria de obter qualquer prazer que seja. $^{7}$

O prazer, portanto, é uma perfeição suplementar acrescida à perfeição que a atividade tem em si mesma e que foi gerada por outras causas que não o prazer. Por isso, não o prazer, mas ser o que se é será o fim da atividade e de sua perfeita execução. O prazer será apenas uma perfeição (telos) que sobrevém à realização da atividade. Como conclui belamente Riel:

O prazer é deste tipo: ele não é uma perfeição intrínseca a uma atividade, mas antes um excedente (surplus), uma qualidade que lhe sobrevém. Aristóteles, portanto, claramente reconhece que atividade e prazer não são idênticos. O prazer pode ser um excedente extremamente desejável e gratificante, mas a atividade enquanto tal pode ser realizada sem prazer. $^{8}$

Ademais, conceber o prazer como fim da atividade perfeita é querer atribuir uma tese excessivamente hedonista a Aristóteles que, claramente, se dedicou a distinguir prazer e atividade com vistas a mostrar que o prazer não é senão uma sensação que acompanha a ação moral. Mais ainda, agir sempre em vista do prazer é agir de modo intemperante e ter prazeres excessivos. $\mathrm{O}$ prazer excessivo

7 RIEL, 2000, p. 55.

8 lbid., p. 58, tradução minha. 
parece cumprir bem tal função de finalidade última da ação, uma vez que não importa o valor moral da ação, mas sim se ela dá prazer ou não. E se alguém toma o prazer como fim último de suas ações, isto é, como o critério para agir, inevitavelmente essa pessoa se tornará um intemperante. Por isso, não apenas pelo fato de o prazer ser uma propriedade da atividade e não ser seu fim, mas também por razões morais, não seria possível admitir que ele seja, em termos absolutos, a finalidade da atividade. Ou seja, devemos antes desejar fazer o bem e do melhor modo possível do que desejar ter prazer.

Podemos inferir que a concepção aristotélica do prazer como sendo condição para a perfeita execução da atividade pretende enfraquecer o estatuto do prazer como causa final da atividade, uma vez que ele não deve ser valorizado nem perseguido em detrimento do que é verdadeiramente bom. E se o prazer não é de modo algum causa da boa atividade, então ele não deve ser desejado acima dela; ao contrário, é a boa atividade que deve ser desejada em preferência do prazer que dela possa resultar, como veremos no "Problema II: prazer e virtude".

Tomemos a analogia feita entre prazer e saúde e façamos um breve exame à luz da teoria das quatro causas. Quando interpretamos, na análise feita do segundo Tratado do prazer, que Aristóteles diz que a função da saúde que vem adquirindo o paciente otimiza o processo de cura e que, portanto, funciona como uma espécie de fortalecimento da cura, faz-se necessário distinguir entre a saúde que ainda residia no paciente, a saúde que o paciente passou a adquirir durante o processo de cura e a saúde completamente restabelecida ao fim do processo. Por conseguinte, vemos três momentos distintos no processo de convalescença: um antes de se iniciar a cura, outro durante e outro ainda posterior. $\mathrm{O}$ prazer, assim nos parece, opera como a saúde (isto é, o melhoramento físico) que veio por acréscimo (epigignomenon) durante o próprio processo de cura e que acabou por auxiliá-lo. Assim, a analogia consiste em dizer que o prazer é certa perfeição que sobrevém à finalidade da atividade, como a saúde adquirida sobrevém à cura (finalidade do processo de convalescença). Ou seja, o prazer é uma perfeição na realização da finalidade da atividade e não a própria finalidade da atividade.

O prazer é como uma saúde por acréscimo. Esta saúde por acréscimo não é responsável pela execução adequada do tratamento, isto é, o tratamento não deixaria de ser adequado e nem deixaria de ser executado adequadamente sem tal acréscimo, nem a cura deixaria de ser obtida. A única diferença é que o 
tratamento seria otimizado, tornado mais eficiente, pois a sua execução seria aperfeiçoada na medida em que o paciente fosse ganhando saúde durante o processo de cura. Segundo esta interpretação, o prazer é como a saúde acrescida à convalescença, a qual opera como causa eficiente na efetivação da cura. A causa material da cura é o corpo ainda saudável do paciente, a formal é a própria cura ou restabelecimento da saúde, a final é a realização da cura, a eficiente é o tratamento. Com relação não à natureza da cura, mas à qualidade de sua realização, a saúde que vem adquirindo o paciente é causa eficiente.

Em analogia, para que haja a atividade perceptiva perfeita, a causa material é o corpo daquele que percebe possíveis objetos exteriores em condições adequadas, a formal é o que faz da atividade ser uma atividade perceptiva, a final é a realização perfeita da percepção, e a eficiente é o encontro entre a faculdade e seu objeto em perfeitas condições. Dadas as causas que geram uma perfeita atividade, segue-se necessariamente o prazer, o qual, por sua vez, aperfeiçoa a execução da perfeita atividade. Trata-se aqui, de uma atividade perfeita sendo executada perfeitamente. O prazer é apenas causa eficiente da perfeita execução da atividade. Do ponto de vista moral, como toda atividade virtuosa realizada virtuosamente é necessariamente acompanhada de prazer, então ela é necessariamente executada de modo perfeito. Ou seja, o próprio modo virtuoso de agir implica a perfeita execução da ação virtuosa.

Para finalizar o Problema I, acreditamos ser preciso fazer o seguinte adendo, a saber, a atividade que é acompanhada de um prazer excessivo ou ruim também é aperfeiçoada. Assim, é possível ter a sensação de prazer ao fazer algo vil, e isso também significa agir perfeitamente. Com efeito, da mesma maneira que uma atividade boa, ao ser feita com prazer, torna-se melhor do ponto de vista moral, visto que sua execução será perfeita, uma atividade vil torna-se pior quando executada com prazer, isto é, perfeitamente. Neste caso, basta termos em mente o exemplo do crime perfeito. O crime perfeito é um crime, uma ação ruim, executada da melhor maneira possível, o que implica dizer que o criminoso teve prazer ao realizar o crime. O crime é uma atividade ruim que se torna pior quando realizada com prazer. Pensemos agora em uma ação justa, como a de um rei que deve distribuir os espólios da guerra entre os guerreiros. Esta ação de distribuição pode ser justa se justa for a intenção do rei, se o mesmo assim estiver agindo em conformidade com as normas ou leis. Todavia, será a mais justa possível se o rei for justo, desejar e realizar tal ação em vista dela mesma e tiver prazer em realizá-la. O corajoso, por exemplo, pode agir corajosamente porque 
deseja obter a glória de seu heroísmo. Todavia, se for um verdadeiro guerreiro, ele agirá corajosamente em vista da própria ação corajosa e sentirá prazer em agir assim, independentemente do reconhecimento glorioso posterior. Neste caso, a sua ação será a mais corajosa possível. Em suma, uma ação virtuosa será a mais virtuosa possível se for realizada de modo virtuoso, isto é, perfeitamente, com prazer. Como diz o filósofo:

Aqueles que exercem sua atividade com prazer, a exercem com mais discernimento (krinousi) e exatidão (exakribousin). Assim, aqueles que encontram prazer em se exercerem na geometria, tornam-se geômetras melhores, e eles compreendem melhor seus vários problemas; e similarmente os que amam a música, a arquitetura ou as outras artes progridem (epididoasin) nas obras que lhes são próprias por encontrarem prazer (karontes autôi) (EN X 5: 1175a32-36).

Eis a função do prazer: aperfeiçoar a realização da atividade. Com efeito, dizer que o prazer aperfeiçoa a execução da atividade significa dizer que a executamos com mais acuidade, empenho, por mais tempo, o que torna a atividade mais desejável e sua execução melhor, ou seja, o prazer aprimora a realização da atividade de modo que ela atinja o seu fim o mais perfeitamente possível. Concluímos, retomando o que foi dito em poucas palavras: o prazer é condição necessária não para que seja completa a natureza da atividade, mas para que ela seja exercida perfeitamente. E ser exercida perfeitamente significa, do ponto de vista moral, ser melhor, no caso da boa atividade, e pior, no caso da má atividade.

\section{Problema II: Prazer e virtude9}

\section{Introdução}

O prazer, segundo Aristóteles, exerce um papel relevante na formação do caráter e na regulação de nossas ações morais, o que é evidente quando filósofo afirma que, "a virtude moral diz respeito aos prazeres e dores" (EN II, 3, 1104b9) e apresenta, em seguida, oito razões como justificativa. Destas, destaco quatro que, a meu ver, são as mais relevantes. Em primeiro lugar, por causa do prazer (dia tên hêdonên) realizamos ações vis, e por causa da dor nos afastamos das

9 Uma primeira versão deste texto foi publicada com o título Prazer e virtude segundo Aristóteles na revista Dois pontos, Curitiba, São Carlos, v. 10, n. 2, p. 315-342, out. 2013. 
belas ações; o que justifica a importância de se educar desde cedo a criança a gostar (chairen) e desgostar do que se deve. Em segundo lugar, a virtude diz respeito às ações e emoções (pathê) e toda ação e emoção são acompanhadas de prazer $^{10}$; o que pressupõe que, como acompanhante, ele terá algum efeito sobre nossas ações e, portanto, na aquisição das disposições morais. Em terceiro lugar, a relação da disposição moral com o prazer e a dor parece ser necessária e de absoluta relevância moral, o que torna a investigação sobre tal relação crucial, pois "pelos prazeres e dores os homens tornam-se vis, ao buscar e evitar aqueles que não se devem, ou quando não se devem, ou como não se devem ou de tantos outros modos nos quais se possa definir" (1104b21-24), ${ }^{11} \mathrm{e}$, inversamente, tornam-se bons, a depender de quais, como e quando buscam os prazeres e evitam a dores. Isso se explica pela natureza mesma de toda disposição moral, pois que esta é determinada pelas coisas que tornam a alma melhor ou pior com relação a elas, isto é, aos prazeres e dores. Em suma: o tipo de comportamento com relação aos prazeres e dores é determinante na constituição da disposição moral, tendo em vista que esta se constitui a partir da regularidade de ações diante das emoções. De onde conclui Aristóteles o que se segue: "assumimos, portanto, que a virtude é de tal qualidade conforme o bem agir em relação aos prazeres e dores, e que o vício é o contrário" (1104b26-7). Por fim, em quarto lugar, Aristóteles nos diz que o prazer acompanha todo objeto de busca, seja ele um objeto propriamente prazeroso, seja ele o belo e o útil, a saber:

Como são três os objetos de busca e três os de fuga - o belo, o proveitoso e o agradável - e três contrários - o feio, o danoso e o penoso -, o homem bom é correto a respeito de todos eles, mas sobretudo a respeito do prazer, pois este é comum aos animais e acompanha a tudo o que cai

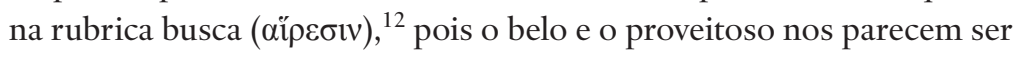
prazerosos (1104b30-1105a1).

10 O mesmo é dito mais adiante, em 1105b21-3.

11 Linhas adiante, a mesma tese será dita da seguinte maneira: "aquele que se comporta bem com relação aos prazeres e dores será bom, quem se comporta mal, será mau” (1105a13-4).

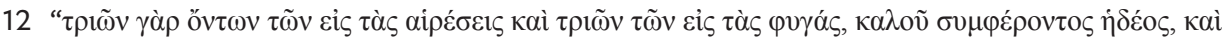

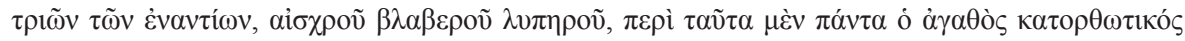

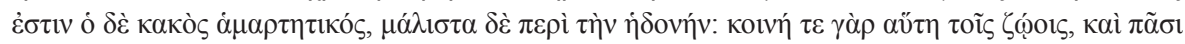

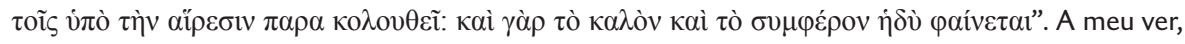

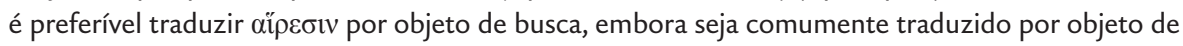
escolha, pois os animais não escolhem, mas buscam algo na medida em que o desejam. Portanto, 
Ora, se o prazer acompanha todo objeto de busca, isto é, todo objeto de desejo que seja realizável, ${ }^{13}$ se o modo de se comportar com relação aos prazeres e dores é tão importante para a formação do caráter e, evidentemente, para regularmos nossas ações, ${ }^{14}$ então, parece ser evidente que o filósofo tenha atribuído ao prazer um papel determinante na conduta moral. O ponto problemático que norteará esta investigação é saber o quão determinante ele é. Não poderia ser, ele próprio, o critério para determinar o valor moral da ação, pois se o fosse, a boa ação seria identificada com o ter prazer e a má ação com o ter dor, contrariando o que pretende estabelecer Aristóteles.

Explico-me. Se o prazer é determinante para a aquisição da disposição moral, pois nos tornarmos bons se o buscamos corretamente e vis se assim o fazemos incorretamente, como foi dito, então devemos compreender o tipo de determinação que ele exerce na orientação de nossas ações. Uma hipótese que poderia ser levantada se o nosso comportamento fosse absolutamente determinado pela busca de prazer seria a seguinte: se assim fosse, bastaria dizer que a busca correta pelo prazer é tudo o que deve aprender aquele que pretende se tornar virtuoso, e que o fim de suas ações não deve ser o prazer simplesmente, mas o prazer qualificadamente bom.

Diante desta hipótese, duas perguntas devem ser feitas para saber se ela se sustenta ou não. Em primeiro lugar, como é possível ter um prazer

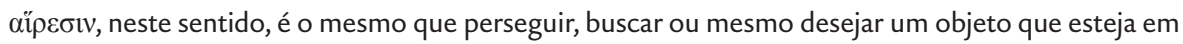
nosso poder realizar e não uma operação racional de eleição de um objeto antes que outros. Se optarmos pelo termo escolha para traduzi-lo, então temos que ter em mente que se trata de uma simples escolha, tão simples que poderia ser atribuída aos animais, e não poderia se tratar da escolha deliberada. Como razão suplementar para justificar esta tradução, cito Zingano (2008, nota 1104b30-31): "A expressão para objetos de busca é ta eis tas haireseis e a tentação é grande de traduzir por objetos de escolha, mas a noção de hairesis está frequentemente associada e mesmo assimilada à diokton, tipicamente objeto de busca (cf. I 5 1097a30-34; VII 10 1151b1), o que sugere fortemente a tratá-la como um sinônimo desta. A vantagem é também conceitual, pois, como Aristóteles insiste, toda escolha diz respeito a um meio, enquanto o objeto de busca é um fim a partir do qual deliberamos sobre os meios". Deixo registrado aqui que me utilizarei de sua tradução, com possíveis modificações, para todas as outras passagens referentes ao Tratado da Virtude Moral: ENI 13 - III 8: 1102a5 - 1115a3. As outras passagens são minhas traduções.

13 Evidentemente, buscar algo é distinto de simplesmente desejar algo, pois posso desejar e não buscar, como o desejo por coisas impossíveis, por exemplo, o desejo pela imortalidade. Porém, no que diz respeito às coisas possíveis, isto é, que estão em nosso poder realizar, desejar e buscar coincidem.

14 Como o próprio filósofo estagirita nos diz: "nós regulamos (kanonizomen) as ações, uns mais, outros menos, pelo prazer e pela dor” (1105a4-5). 
qualificadamente bom? Em segundo lugar, é o prazer, mesmo que bom, que deve ser desejado em vista dele mesmo e assim operar como critério último da ação virtuosa? Quanto à primeira pergunta, veremos que a definição de prazer tal qual proposta por Aristóteles, no segundo tratado do prazer (EN X 1-5), condicionará o bom prazer à realização da boa atividade, o que significa dizer que só é possível ter um bom prazer ao se realizar uma boa atividade. Quanto à segunda pergunta, como o bom prazer depende de a atividade ser boa e esta depende do bom julgamento do agente, então é este julgamento, enquanto expressão da reta razão, que será o critério último da ação virtuosa. Ademais, veremos que o prazer não poderia operar como critério da ação virtuosa porque é possível ter prazer com ações vis - ora, se o prazer fosse critério, então qualquer ação que desse prazer, seja ela boa ou vil, deveria ser realizada -, o que implica constatar que a ação deve ser objeto de desejo e não o prazer. Ou seja, o prazer não poderia ser objeto de desejo do virtuoso, embora seja sua consequência inevitável.

Com efeito, bem sabemos que, segundo o Estagirita, o bem e não o prazer deve ser o fim último de nossas ações. Que o fim último, a felicidade (eudaimonia), é o bem a ser desejado em vista de si mesmo, e não o prazer, Aristóteles já nos demonstrou desde os primeiros capítulos de sua Ética Nicomaqueia. Contudo, o prazer, mesmo não sendo causa suficiente, certamente será causa necessária para a realização da felicidade. Isso significa dizer que o prazer é determinante, por ser necessário, mas não suficiente, para a realização da felicidade. Do contrário, bastaria ter prazer para ser feliz, o que não é o caso. ${ }^{15}$ Se a felicidade não pode ser identificada com o prazer, tampouco ele poderia ser excluído de seus elementos constituintes. Afinal, uma vida em função do prazer é antes escrava do prazer e se aproxima de uma vida bestial do que propriamente humana; ${ }^{16}$ todavia, como diz a maioria, a felicidade existe "com prazer" (meth'hêdonês). ${ }^{17}$ Compreender, portanto, em que sentido o prazer é necessário para a felicidade pressupõe compreender a relação necessária entre virtude e prazer, visto que a virtude é a causa principal da felicidade.

O prazer, como veremos, não pode ser nem $o$ bem absoluto, nem $o$ mal absoluto, embora possa ser um bem se estiver acompanhando uma boa atividade. 
Ora, se bastasse ao virtuoso desejar o que lhe dá prazer e assim agir conformemente, então o prazer teria de ser considerado o bem em absoluto, e Aristóteles teria de ser partidário de um hedonismo radical, como foi Eudoxo. Se, por outro lado, o virtuoso não sentisse qualquer prazer ao agir, então o prazer teria de ser considerado o mal em absoluto, como postulou Espeusipo. Seria deveras absurdo, ou mesmo sem sentido, se Aristóteles defendesse uma concepção anti-hedonista diante da importância que ele mesmo confere ao prazer em sua ética.

Podemos dizer, sem ressalvas, que o hedonismo moderado sustentado por Aristóteles se apresenta claramente no tipo de relação que ele estabelece entre virtude e prazer, a saber: o virtuoso não age tendo em vista o prazer por ele mesmo, mas certamente sente prazer ao agir. Com a exposição da definição de prazer do segundo tratado do prazer, e da tese da diferença específica entre os prazeres, pretendo tornar patente que a definição do prazer como um fenômeno que não existe senão enquanto um acompanhante da atividade aduz à tese de que o prazer não poderia ser o critério para a ação virtuosa. Isso porque o prazer não é o objeto sobre o qual incide o julgamento do virtuoso, visto que ele não existe por ele mesmo ou em si mesmo, ou seja, a sua existência e natureza dependem inteiramente da existência e da natureza da atividade a ser realizada.

Ainda assim, partidários de um hedonismo radical, poderíamos dizer que a atividade percebida como prazerosa deveria ser escolhida em detrimento da atividade apreendida como virtuosa. Todavia, se ser prazerosa fosse o critério para se escolher determinada atividade a ser realizada, como as atividades vis também são prazerosas, logo, qualquer atividade, independentemente de seu valor moral, poderia ser escolhida. Para que o prazer, isto é, a atividade prazerosa não ocupe o lugar da atividade virtuosa na escolha correta, Aristóteles postula que o bom julgamento deverá incidir sobre a atividade por ela ser boa e não por ela ser prazerosa, ou seja, o julgamento correto buscará apreender o valor moral da atividade e não o seu aspecto prazeroso. Com efeito, o virtuoso será aquele que julga qual é a melhor atividade a ser feita e não qual é o prazer a ser fruído em dada situação. Isso significa que tal atividade não será boa por parecer prazerosa ao virtuoso, mas, ao contrário, ela lhe parecerá prazerosa por ser boa. O virtuoso não age corretamente para ter prazer, ou seja, não é o prazer a causa de sua ação, mas é por agir assim que ele tem prazer, ou seja, é por ser boa que sua ação lhe causa prazer - e não ao contrário: por ser prazerosa que ela é boa. Em outros termos, a causa do prazer do virtuoso é a realização da boa ação e a causa da realização da boa ação é ela mesma. Ou seja, a ação virtuosa não é a 
realização de uma atividade por ela ser prazerosa, mas por ela ser boa, embora a sua realização seja necessariamente prazerosa ao virtuoso.

Tendo em mente tais considerações, pretendo mostrar que a concepção de prazer que Aristóteles apresenta, no segundo tratado, expressa sua visão hedonista moderada e corrobora com a tese de que o virtuoso age não devido ao prazer, mas certamente com prazer.

\section{O hedonismo moderado de Aristóteles}

Não parece ser de pouca monta o fato de o filósofo ter defendido uma tese hedonista moderada, em que o prazer, embora não seja $o$ bem, possa ser $u m$ bem, uma vez que esteja acompanhando uma boa atividade. Como vimos, o prazer não poderia ser o bem supremo, pois ele é causa necessária, mas não suficiente da felicidade. ${ }^{18}$ Por outro lado, se o prazer fosse $o$ mal em absoluto, ele não poderia ser considerado uma das causas da felicidade e jamais poderíamos ter prazer com o que é bom. Em seus dois tratados do prazer, ${ }^{19}$ Aristóteles critica as opiniões anteriores sobre o prazer de modo a defender a tese de que o prazer não é o bem ou o mal em absoluto, mas que, cumpridas certas exigências, ele possa ser considerado um bem. Veremos, mais adiante, quais são estas exigências a serem cumpridas para que o prazer possa ser um bem.

Depois de ter definido o objeto de sua ética, a felicidade (eudaimonia), Aristóteles, no livro I, capítulo 8 (1098b9-1099b8), passa a verificar a validade de tal definição à luz das opiniões correntes. Ele nos diz que são três as opiniões que estão em harmonia com a sua definição de felicidade. A primeira delas é aquela que diz que o fim se identifica com as ações ou atividades, pois estas são bens da alma. A segunda diz que o homem feliz vive e age bem, pois a felicidade é um tipo de viver e agir bem. Por fim, a terceira opinião é a de que a felicidade inclui, de alguma maneira, todas as características que lhe foram atribuídas, a saber: a virtude, a prudência, a sabedoria, o prazer e os bens exteriores. Além de a felicidade envolver os bens supracitados e de ser o exercício da virtude e não apenas a

18 Cf. ENI, 5, 1095b15-18.

19 Como vimos no primeiro capítulo deste livro, o primeiro tratado compreende os capítulos 12 ao 15 do sétimo livro da Ética Nicomaqueia, e o segundo tratado, os capítulos 1 ao 5 do décimo livro da referida obra. Resumidamente, podemos dizer que, nos dois tratados, o filósofo se opõe à opinião radicalmente anti-hedonista, atribuída a Espeusipo, de que o prazer é o mal, bem como à opinião estritamente hedonista, atribuída a Eudoxo, de que o prazer é o bem. 
sua posse, o filósofo acrescenta, em seguida, que a vida daqueles que são felizes é em si mesma prazerosa, pois a vida virtuosa é em si mesma prazerosa. Ao justificar tal afirmação, o filósofo demonstra que a felicidade necessariamente envolve prazer e este ponto nos interessa sobremaneira. Vejamos o trecho referido:

Com efeito, a vida deles <isto é, dos virtuosos> é em si mesma prazerosa ( $\kappa \theta^{\prime} \alpha$ vĩòv lhe é prazeroso aquilo que ele ama. Por exemplo, o cavalo é prazeroso para aquele que ama cavalos; o espetáculo para aquele que ama assistir espetáculos; e, similarmente, as ações justas são prazerosas para os que amam a justiça e, em geral, as ações virtuosas para os que amam a virtude. Assim, para a maioria os prazeres são conflituosos, porque eles não são, por natureza, prazerosos; enquanto que as coisas prazerosas por natureza são prazerosas para os que amam o belo e estas são sempre ações conforme a virtude, de tal modo que são prazerosas em si mesmas e para os que amam o belo. ${ }^{20} \mathrm{~A}$ vida deles, portanto, não necessita do prazer como uma espécie de ornamento ( $\pi \varepsilon \rho$ ió $\pi \tau o v)$, mas tem prazer em si mesma. Além do que já dissemos, o homem, portanto, que não frui das belas ações não é nada bom. Tampouco se chamaria justo aquele que não frui de ações justas; nem generoso aquele que não frui de ações generosas e similarmente com as outras virtudes. Em sendo assim, ações em conformidade com a virtude devem ser em si mesmas prazerosas. Mas também são maximamente boas e belas, se o homem bom as julga

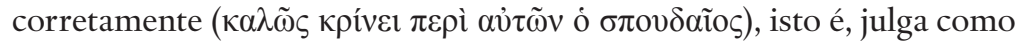
já dissemos. A felicidade é, portanto, o que há de melhor, mais belo e prazeroso e essas qualidades não estão separadas como estão no epigrama de Delfos - o mais belo é a justiça/ e o melhor é a saúde;/ mas o mais prazeroso é conquistar o que amamos -, pois todas essas qualidades pertencem às melhores atividades. E essas ou uma dessas é a melhor de todas - aquela que dizemos ser a felicidade (1099a7-30).

No trecho acima, o Estagirita mostra que a felicidade, isto é, a vida dos virtuosos, é em si mesma prazerosa e que, portanto, não seria possível admitir que o prazer seja mero ornamento a ser acrescido ou retirado facilmente deste tipo de vida. Esta tese, como veremos, implica três coisas: (i) a ação virtuosa é por

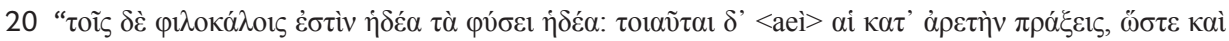

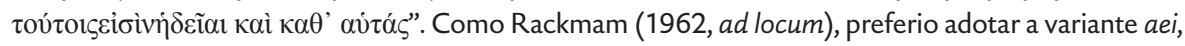
o que favorece a tese de que as ações em si mesmas ou por natureza prazerosas são sempre virtuosas. 
natureza prazerosa e o virtuoso necessariamente sente prazer ao realizá-la, sendo o prazer que ele sente um sinal de sua disposição virtuosa (1099a17-21); (ii) além de ser prazerosa, tal ação é boa e bela em mais alto grau, ou seja, o prazer, assim como o bem e a beleza, é um atributo próprio da ação virtuosa (1099a2225), e, (iii) que a inscrição de Delfos é falsa, pois a reunião de excelência, beleza e prazer se expressa em uma única atividade, a saber: a felicidade (1099a25-31). Comecemos pela crítica à inscrição de Delfos.

Segundo tal inscrição, o belo, o melhor e prazeroso aparecem separados, ao contrário do que compreende Aristóteles, pois, para o mesmo, a felicidade é a melhor e mais bela atividade, portanto, a mais amada e desejada dentre todas as atividades. Se a realização do que amamos ou desejamos proporciona prazer, então a realização daquilo que mais amamos, a felicidade, certamente proporcionará o máximo de prazer. Isso significa que a crítica à inscrição de Delfos parece ter o intuito de mostrar que o prazer é um atributo próprio à felicidade, isto é, o prazer necessariamente ocorre ao realizarmos o bem viver. É exatamente esta concepção de felicidade como atividade necessariamente prazerosa que nos interessa. Passemos agora ao primeiro item, isto é, compreender por que a ação virtuosa é por natureza virtuosa.

No início do trecho citado acima, o filósofo postula que a vida dos virtuosos é em si mesma prazerosa, pois as ações conforme a virtude são prazerosas em si mesmas e para os que amam a virtude. Ou seja, o que é realmente prazeroso assim o é em si mesmo e para quem o sente, assim como o que é bom assim o é em si mesmo e para quem ama o que é bom, isto é, para aquele que possui uma boa disposição. Isso se explica pelo fato de existir, segundo o filósofo, tanto o bem em si (haplôs), como o bem para mim (hautôi) ou fenomênico. Do mesmo modo, há tanto prazer haplôs, como prazer hautôi. ${ }^{21}$ Com efeito, "o que é bom por natureza é o que é bom e prazeroso ao homem bom e em si mesmo" (EN IX, 9, 1170a15). ${ }^{22}$ Ainda, como analisaremos adiante, nesta outra passagem, o Estagirita expõe esta mesma concepção: "em todos esses casos, é-se da opinião que o que aparece ao virtuoso (to phainomenon tôi spoudaiôi) é o que é bom. E, se isso que falamos está correto como parece estar, a virtude e o homem bom qua bom são a medida ( $\mu \varepsilon ́ \tau \rho o v)$ de cada coisa. Portanto, as coisas que lhe

21 Cf. EN VIII 2: 1155b21-3.

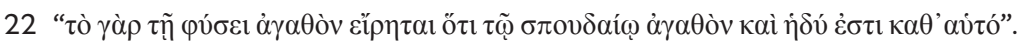


aparecerem prazerosas são prazerosas e agradável é aquilo com o qual ele se deleita” (EN X, 5, 1176a16-19).

Quanto ao que foi dito é preciso ressaltar que não é o que é bom para o virtuoso que é bom em si mesmo, mas exatamente o contrário: o que é bom em si mesmo assim parece ser bom para o virtuoso, justamente porque ele é capaz de julgar corretamente o que a situação particular determina como sendo o melhor a ser feito. ${ }^{23}$ Ora, sabemos que o realismo aristotélico não é complacente com a máxima de Protágoras de que "o homem é a medida de todas as coisas”, pois, para ele, a medida do que é bom é dada pelas circunstâncias particulares presentes na realidade e o virtuoso é justamente aquele que é capaz de apreender verdadeiramente o que é realmente bom. Por isso, assim como o bem existe tanto em si mesmo como para quem o toma como tal, a ação virtuosa é tanto em si mesma prazerosa como para quem a toma como prazerosa, ou seja, para quem ama agir virtuosamente. Mas não é por apreendê-la que ela se torna prazerosa por natureza, ao contrário, é porque ela é prazerosa por natureza que o virtuoso pode apreendê-la enquanto tal. Em suma: ela não é prazerosa em si mesma por assim parecer ser ao virtuoso. Ao contrário, ela é prazerosa para o virtuoso por assim ser em si mesma ou por natureza.

Ademais, quem não tem prazer com o que é prazeroso por natureza não pode ser considerado virtuoso por excelência. Afinal, "o homem que não frui

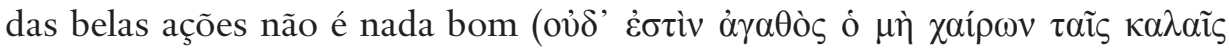
$\pi \rho \alpha ́ \xi \varepsilon \sigma ı) ”(1099 a 17)$. O virtuoso necessariamente sente prazer ao agir virtuosamente e o prazer que ele sente é um sinal de que ele é, de fato, virtuoso. Além do temperante, que se caracteriza justamente por ser moderado quanto aos prazeres físicos, sobretudo os do tato e paladar, outros dois exemplos claramente confirmam esta tese de que o virtuoso necessariamente sente prazer ao agir virtuosamente: o do generoso e o do corajoso. O generoso sente prazer em dar com vistas ao belo e corretamente; como diz o filósofo: "ele dará com prazer ou sem dor, pois a ação segundo a virtude é prazerosa ou sem dor - certamente não é penosa” (EN IV 1: 1120a26-7).

23 Esta tese do virtuoso como aquele que não institui o bem na realidade, mas que o apreende corretamente, isto é, que toma como um bem para si o que é bom em si ou por natureza, também é evidente neste outro trecho: "o homem virtuoso julga corretamente cada coisa e em cada uma a verdade se manifesta a ele, pois há coisas belas e prazerosas próprias a cada disposição e presumivelmente o homem virtuoso se distingue sobretudo pelo fato de ver o verdadeiro em cada coisa, como se fosse um padrão e uma medida delas" (EN III 4: 1113a31-4). 
Mais exemplar ainda é o caso do corajoso, cuja ação corajosa lhe é prazerosa, mesmo que seja acompanhada de dores físicas. Aquele que é propriamente corajoso faz o que é bom em vista do que é bom e sente prazer com isso. Os corajosos por homonímia recebem apenas o nome de corajosos, pois não são realmente corajosos, ou seja, eles não agem em vista do bem, da própria ação corajosa, mas sim em vista do prazer da honra, ou do elogio posterior, ou ao menos para não serem desonrados ou punidos. ${ }^{24}$ Segundo Aristóteles, "alguém deve ser corajoso não por coerção, mas porque é belo ser assim” (EN III 9: 1116b3). ${ }^{25}$ Ora, a ação corajosa é prazerosa para quem é verdadeiramente corajoso, ainda que seja preciso enfrentar certas dores, como as dores físicas na batalha e mesmo a pior das dores: a própria morte ou a morte de alguém querido. $\mathrm{O}$ caso do corajoso parece funcionar bem como um paradigma para determinar que o prazer seja, sobretudo, uma sensação da alma (1099a9), ${ }^{26}$ pois mesmo sentindo dor física, o corajoso sente prazer ao agir corajosamente, isto é, ao ser virtuoso e desejar o bem em vista dele mesmo. Tendo como alvo o bem, o corajoso não se desvia de seu alvo por não suportar a dor física, ou por buscar o prazer acima do que é bom. O mesmo, obviamente, deve se seguir com relação às outras virtudes.

Tendo em vista o que foi dito, podemos inferir que o virtuoso necessariamente sente prazer ao agir, porque a ação virtuosa lhe aparece como sendo prazerosa, mesmo que ela implique dor. Em poucas palavras: o virtuoso só suporta as dores que deve suportar, ou evita os prazeres que deve evitar porque tem em mira e se regozija com o que é belo e bom. Como diz Alexandre de Afrodisia, "nós escolhemos atividades virtuosas mesmo que elas possam, às vezes, nos causar sofrimento ou dor, como ocorre no caso das atividades corajosas" (Problema 13: 144, 11-14).

Como argumento suplementar, Aristóteles postula a tese de que o prazer que sente o agente é um sinal ou indício (sêmeion $)^{27}$ de que a ação virtuosa é

24 Sobre os exemplos de coragem por homonímia, ver EN III 8: 1116a15 et. seq.

25 Ver também EN III 8: 1115b23-24.

26 A ideia de que o prazer é propriamente uma sensação da alma está presente não apenas no trecho citado de ENI 8, mas também em III 10, pois, em algumas atividades, como na ambição (philotimia) e no amor ao aprendizado (philomatheia), sentimos prazer menos com o corpo sendo afetado e mais com a mente (ala mallon tes dianoias). Ou seja, o corpo sofre algo, pois há percepção, imaginação e alterações físicas, mas a sensação de prazer parece ser predominantemente uma atividade da alma.

27 A tese de que o prazer é um sinal do tipo de disposição será exposta pelo filósofo em EN II 3: 1104b4. Ver também EN X 5: 1176a27-29. Alexandre de Afrodisia afirma que o prazer é um sinal de que a 
realizada por alguém virtuoso. Isso se explica por duas razões: em primeiro lugar, sabemos que toda ação é acompanhada de prazer ou dor, e que o virtuoso não age tendo o prazer como fim, mas certamente sua ação é acompanhada de prazer. ${ }^{28}$ Em segundo lugar, dizer que temos prazer ou dor ao agir desse modo ou de outro sinaliza o nosso tipo de caráter, pois evidencia o tipo de desejo que está operando: se for um desejo virtuoso, então a realização do bem em vista dele mesmo proporcionará um bom prazer; se não for, então ou o objeto de desejo será algo vil, como no caso do vicioso, ou não será o próprio bem, mas sim sua consequência prazerosa ou não penosa, como parece ocorrer nos casos de controle (encrateia) ou de descontrole (acrasia)..$^{29}$ Logo, haverá ou um prazer ruim, isto é, aquele que acompanha a ação vil, ou um prazer pela consequência da ação boa, e não pela própria ação. ${ }^{30}$ Nas palavras de Aristóteles:

Deve-se tomar os prazeres e as dores nas ações como sendo sinais ( deleita ( $\chi \alpha i ́ p \omega v)$ com isso é temperante; ao passo que quem se incomoda com isso é intemperante; quem suporta as coisas temíveis e se deleita, ou ao menos não sofre, é corajoso; ao passo que quem sofre é covarde ( $E N$ II 3:1104b3-8).

Se, pois, o prazer e a dor indicam que tipo de disposição possui aquele que pratica a ação, então é de se presumir que agir bem implica sentir prazer e dor com o que se deve e como se deve. Mais ainda, se o prazer é sinal da boa ação, então é porque a boa ação foi realizada com prazer.

Quando o filósofo diz que "a virtude é de tal qualidade conforme o bem agir em relação aos prazeres e dores, e que o vício é o contrário” (EN II, 3,

virtude e a felicidade estão presentes no homem virtuoso: "[...] o prazer, acompanhando a atividade que surge desse modo [desimpedido], será um sinal de que a felicidade está presente para aqueles que agem deste modo (isto é, virtuosamente), antes de ser [ele mesmo] a felicidade" (Problema 13: 143, 28-30).

28 Cf. EN II 3: 1105a4.

29 Não cabe analisarmos em detalhe o prazer que sente o controlado ou o descontrolado, mas, brevemente, podemos dizer que ambos parecem não desejar o bem por ele mesmo, como ocorre com o virtuoso, mas a consequência prazerosa ou não penosa de realizá-lo, isto é, a consequência de ser elogiado ou de não ser punido por fazer o que é bom em detrimento ao que conduz o apetite excessivo.

30 O tipo de prazer será determinado pelo tipo de atividade, se boa, um bom prazer, se má, um mau prazer, como veremos adiante no texto, na seção "A definição de prazer”. 
1104b26-7), pois nos tornamos bons ao buscarmos corretamente o prazer e maus ao buscá-lo incorretamente, não devemos compreender que ele esteja propondo uma espécie de hedonismo radical, em que o prazer funcionaria como critério da boa ação. Ao contrário, a boa ação é critério para o prazer, pois não se trata de sentir prazer com qualquer coisa que pareça prazerosa, mas com o que é preciso sentir e do modo que é preciso sentir, isto é, moderadamente. Ora, o virtuoso é justamente aquele que sente prazer com o que se deve e na justa medida, e que também sabe enfrentar ou evitar as dores necessárias. Isso porque ao virtuoso lhe é prazeroso o que é verdadeiramente um bem. Com efeito, para o homem bom as boas coisas lhe aparecem como prazerosas e para o homem mau, as más. ${ }^{31}$

Conforme a análise do trecho 1099a7-30, torna-se evidente que tipo de relação existe entre prazer e felicidade e o quão necessário é o prazer para vivermos bem. Do que foi dito até o momento, podemos concluir que, desde o início da Ética Nicomaqueia, é preciso que o prazer possa ser considerado um bem, visto que tanto a felicidade, como a virtude são bens e são coisas naturalmente prazerosas. Desse modo, Aristóteles parece ter defendido uma tese hedonista moderada, em que o prazer, embora não seja $o$ bem, possa ser um bem uma vez que esteja acompanhando a realização de uma boa atividade. As condições pelas quais o prazer pode ser um bem serão fornecidas no segundo tratado do prazer, como veremos adiante.

\section{O prazer não é critério para a ação virtuosa}

A ação virtuosa, como vimos, é em si mesma prazerosa e também é necessariamente prazerosa para o virtuoso, pois ele ama agir virtuosamente. Todavia, mesmo sendo em si mesma prazerosa e necessariamente prazerosa ao virtuoso, a ação virtuosa deve ser desejada e escolhida por ser boa e não por ser prazerosa. Neste momento de nossa investigação, é preciso mostrar por que, segundo Aristóteles, não é por ser prazerosa que a ação virtuosa deve ser desejada, mas por ela ser boa. Como veremos, sustentar esta tese afasta o filósofo de uma possível adesão ao hedonismo exacerbado.

31 O mesmo diz Tomás de Aquino ao interpretar EN II 3 (1993, lição XI, §1470): “Com relação ao prazer, uma coisa é denominada má, e outra, da mesma forma, boa. Um homem bom é tido como aquele que tem prazer por coisas boas. Um homem mau, aquele que se deleita por coisas más". 
Sabemos que, segundo Aristóteles, a ação virtuosa deve ser desejada em vista dela mesma, isto é, por ser boa e não por resultar em prazer. Isso se justifica a partir de dois argumentos: o primeiro é que devemos desejar e escolher o que é bom a ser feito, tendo como critério o próprio bem e não o prazer, ou seja, o julgamento sobre o que é realmente um bem e não o julgamento sobre o que é prazeroso. Mesmo porque, o julgamento sobre o que é prazeroso determina o que é prazeroso, mas não necessariamente o que é bom, já que não há identidade absoluta entre prazer e bem. O segundo argumento consiste em dizer que o erro moral ${ }^{32}$ decorrente dos prazeres consiste em desejarmos fazer algo que seja bom por parecer prazeroso e não por ser de fato bom, pois comumente escolhemos antes o que simplesmente nos parece ser prazeroso do que o que a razão nos diz que é bom. Neste caso, o erro moral ocorre porque o prazer é tomado como critério do que é bom, e não o contrário, o que é bom como critério para se ter prazer. Todavia, se o critério para fundamentar o que é bom fosse o que aparece como prazeroso, a ética aristotélica seria absolutamente hedonista e a figura elogiável por excelência não seria a do prudente e sim a do intemperante. Afinal, o intemperante age tendo como fim apenas o que lhe dá prazer, independentemente de seu valor moral. ${ }^{33}$

Certamente, é tese bem estabelecida na ética aristotélica que a ação virtuosa não deva ser desejada em vista do prazer, mas sim em vista de ela mesma ser virtuosa. Porém, como comumente desejamos o que nos aparece como prazeroso e o que nos aparece como prazeroso não nos fornece um critério moral aceitável, então, deve ser possível e necessário que o que nos apareça como prazeroso esteja condicionado ao que julgamos corretamente ser bom. Afinal, também é tese bem estabelecida que o critério moral deva ser o bom julgamento, isto é, aquele mesmo que o prudente faria.

Vejamos agora como a definição de prazer proposta no segundo tratado corrobora com a tese de que o virtuoso age devido ao bem e não devido ao prazer, uma vez que o seu julgamento incidirá sobre a atividade e não sobre o prazer.

32 Cf. EN II, 2: 1104b8-13.

33 Ou seja, para saber o que dá prazer, basta discriminar sensivelmente o objeto prazeroso. Não faz sentido ao intemperante avaliar moralmente o prazer que ele busca, pois ele faz um uso meramente instrumental da razão, isto é, ele apreende os meios mais eficazes para realizar o seu prazer. Em EN III 11: 1119a19-21, Aristóteles nos diz que o intemperante é aquele que tem mais em conta os prazeres que persegue do que o que é digno (axias). 


\section{A definição de prazer}

Pretendemos mostrar em que sentido a definição do prazer e a tese da diferença específica entre os prazeres corroboram com a tese de que o prazer não poderia servir como o critério para a realização da boa atividade.

Depois de ter fornecido, em EN X 4, os atributos essenciais do prazer, a saber, que ele é um todo completo e indivisível e que a atualização de sua essência é imediatamente completa, Aristóteles chega à definição de prazer, no capítulo seguinte (1174b32-1175a22). Em verdade, a definição não é fornecida de modo claro e contundente, mas por acréscimo de atributos no decorrer do capítulo. Primeiramente, foi dito que ele é um todo completo e indivisível, mas dizer isso apenas garante que a sua natureza não seja processual. ${ }^{34}$ Ainda é preciso dizer em que sentido e sob quais critérios podemos efetivamente considerá-lo um bem, pois considerá-lo como um todo completo e indivisível certamente não nos fornece critério algum de valoração moral sobre a natureza do prazer, apenas garante que ele possa ser um bem por não ser um processo. $\mathrm{O}$ critério, como veremos, dependerá da natureza da atividade à qual ele pertence. Passemos a definição propriamente dita.

O prazer é definido como uma perfeição que sobrevém (epigignomenon ti telos) ${ }^{35}$ e retroage sobre a própria atividade (energeia) à qual pertence aperfeiçoando-a. Diante de tal definição, interessa-nos sobretudo entender em que sentido o prazer é próprio ou pertence (oikeia) a uma atividade. Deixemos de lado, para a presente análise, o seu atributo de ser capaz de aperfeiçoar (teleiô̂) a atividade. ${ }^{36}$ Brevemente, podemos dizer que oikeia significa "pertencer" ou "ser próprio a". No caso, o prazer que pertence a uma atividade é aquele que vem a ser em virtude da natureza da própria atividade que o agente está atualmente realizando. ${ }^{37}$

Com efeito, o prazer pertence à atividade de modo a não existir nem lógica nem ontologicamente separado dela, pois não apenas a sua existência, mas também a sua definição dependem da existência e da definição da atividade.

34 Ao comparar ter prazer com ver ou ter qualquer outra sensação, Aristóteles iguala a sensação de prazer a uma atividade tal qual a perceptiva, distinguindo-o do movimento. Como ele diz: "não é possível se mover senão ao longo do tempo, mas é possível sentir prazer (hêdesthai), pois aquilo que existe em um instante é um todo completo (to gar entoi nun holon ti)" (EN X, 4, 1174b9). 
Ontologicamente, pois não há prazer sem atividade (1175a21); e, logicamente, pois não está nem no tempo, nem por natureza separado da atividade, ao contrário do desejo, que existe anteriormente à realização da atividade. Ou seja, o prazer é uma atividade que não subsiste por si mesma, mas é absolutamente dependente da atividade perceptiva ou noética a qual pertence. ${ }^{38}$

Por isso, não há definição do valor moral do prazer senão a partir do valor moral atribuído à atividade. E como as atividades são distintas e variadas, também o serão os prazeres. Nas palavras do filósofo:

Diferindo as atividades quanto à bondade e à vileza, e sendo umas dignas de serem perseguidas, outras evitadas, e outras ainda neutras, o mesmo se dá também com os prazeres; pois, para cada atividade, há um prazer

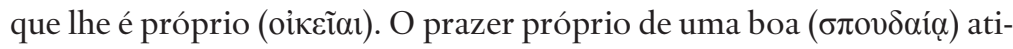

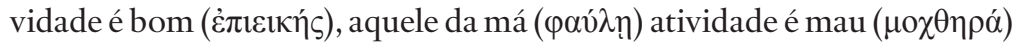
(ENX 5: 1175b24-28).

A citação acima estabelece claramente a tese da diferença específica entre os prazeres, que, aos olhos de Alexandre de Afrodisia, nos conduzirá inevitavelmente à seguinte consequência:

Não é dos prazeres produzidos que nós julgamos as atividades que os produzem, ao contrário, nós julgamos os prazeres pelas atividades. As atividades não merecerão ser escolhidas tendo em vista os prazeres, nem serão os prazeres os mesmos em espécie um em relação ao outro (Problema 13, 134, 13-17).

Da tese da diferença específica, segue-se que a distinção entre as espécies de prazeres não poderia ser apenas acidental, ou seja, a diferença entre prazeres não é apenas porque acontece de existir certo prazer segundo certa atividade que difere de outro prazer segundo outra atividade, mas porque o prazer que acompanha a atividade lhe é próprio e se diferencia de outro prazer na mesma medida em que uma atividade se diferencia de outra, visto que sua natureza corresponde à da atividade. Isso explica o fato de que as atividades a serem evitadas pelo temperante (isto é, as atividades do intemperante) dificilmente lhe dariam

38 De todo modo, o Estagirita nos diz que, mesmo sendo estreitamente unidos, seria absurdo confundir o prazer com a atividade à qual ele pertence (EN X, 5, 1175b30-34). 
prazer. ${ }^{39}$ Se não fosse assim, como diferenciaríamos os prazeres que acompanham as atividades vergonhosas dos que acompanham as louváveis? São as atividades vergonhosas e louváveis a causa da diferença entre os prazeres, pois, como diz Alexandre de Afrodisia, "as atividades não derivam o seu valor de escolha dos prazeres, mas os prazeres das atividades, já que é até mesmo por causa das atividades que os prazeres são de certo tipo" (Problema 23, 146, 3-5).

A consequência da definição do prazer como um próprio da atividade e como distinto dos outros conforme a atividade a qual pertence é que não há definição do valor moral do prazer senão a partir do valor moral atribuído à atividade. A partir desse argumento, não se poderia mais sustentar a máxima hedonista de que o prazer é o bem em absoluto; nem a máxima anti-hedonista de que ele é o mal em absoluto. Aristóteles parece se mostrar avesso a uma interpretação essencialista do valor moral do prazer. Afinal, com a tese da diferença qualitativa entre os prazeres e a sua definição como sendo absolutamente dependente da atividade à qual acompanha, faz-se evidente que a qualidade moral do prazer depende da qualidade moral da atividade à qual pertence e o valor da atividade, por sua vez, depende do bom julgamento do homem virtuoso. Vejamos, em seguida, como o filósofo estabelece o bom critério para se determinar a boa ação e, consequentemente, o bom prazer.

\section{O bom critério para a ação virtuosa}

Diante da variedade de espécies de prazeres, Aristóteles estabelece, em EN X 5, que o critério último qualitativo de distinção é o que o homem bom sente, pois,

Em todos esses casos, é-se da opinião que o que aparece ao virtuoso (to phainomenon tôi spoudaiôi) é o que é bom. E, se isto que falamos está correto como parece estar, a virtude e o homem bom qua bom são a

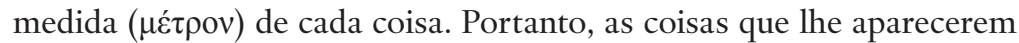
prazerosas são prazerosas e agradável é aquilo com o qual ele se deleita $(1176 \mathrm{a} 16-19) \cdot{ }^{40}$

Como foi dito, a medida de todas as coisas é a virtude e o homem bom qua bom. O seu julgamento moral deve incidir sobre a atividade e não sobre o prazer,

39 Cf. EN III 12: 1119a12-21.

40 Sobre o spoudaios ser como uma medida, um metron, ver também EN IX 4: 1166a13. 
pois o prazer não pode ser o critério de valoração da atividade. O homem bom deseja a boa atividade em vista dela mesma e não em vista do prazer subsequente, o que significa dizer que ela lhe aparece prazerosa, ou seja, que ele encontra o seu prazer na realização da própria atividade e não em sua consequência. A ação virtuosa, por sua vez, é em si mesma boa, mas para que ela seja objeto de desejo de alguém, ela deve aparecer a este alguém como sendo prazerosa. Por isso, a ação virtuosa aparece ao virtuoso como sendo prazerosa por ela ser virtuosa, e não por ela ser prazerosa ou por outra razão qualquer que seja, pois o virtuoso apreende o que é bom e já aprendeu a ter prazer com o que é preciso ter, com o que é de fato bom.

Como sabemos, nem tudo o que é desejado deve ser perseguido e nem tudo o que é objeto de aversão deve ser evitado. É preciso discriminar corretamente o que deve ser perseguido e o que deve ser evitado e, segundo o Estagirita, esta discriminação correta é feita pela chamada reta razão (orthos logos). Este tipo de operação da razão referente às ações não deve se subordinar ao apetite (epithumia), ao desejo pelo prazeroso, e servir apenas para calcular os meios em vista do fim prazeroso. Uma racionalidade que operasse dessa forma seria apenas instrumental, isto é, serviria apenas para obter os meios mais eficazes para realizar o fim prazeroso, e, como diz o filósofo, já estaria corrompida. ${ }^{41}$ Uma racionalidade, por sua vez, moralmente sadia, é aquela capaz de estabelecer corretamente o que deve ser perseguido ou evitado, portanto, de fornecer o bom critério para agir ao apreender o que é verdadeiramente bom ou belo (to kalon). Como diz Alexandre de Afrodisia:

Nos casos em que o belo e o prazer existem juntos, não é o belo que é para ser escolhido em vista do prazer, mas o prazer [em vista do] que é belo, como já mencionamos. Isto é claro pelo fato de que, se o que é belo merecesse ser escolhido em vista do prazer, [o prazer] sendo o fim e merecendo ser escolhido por si próprio, e o belo merecendo ser escolhido [apenas] porque produz prazer, [então] o que é vergonhoso mereceria ser escolhido do mesmo modo que o que é belo, já que [o que é vergonhoso] também produz prazer (Problema 23: 144, 33-145, 4).

Não é difícil constatar que, se o prazer fosse o critério, então qualquer coisa que produzisse prazer deveria ser escolhida, mesmo que fosse algo vil. Por isso,

41 Sobre a razão estar corrompida no caso do intemperante, ver EN III 12: 1119b8-12. 
como foi dito, não é a sensação de prazer ou o desejo pelo prazeroso que poderia distinguir o bom do vil, mas apenas uma discriminação racional que seja capaz de atribuir corretamente um juízo de valor à ação.

Em linhas gerais, sabemos que a razão (logos), segundo o Estagirita, é uma capacidade de distinguir contrários ${ }^{42} \mathrm{e}$ assim apreender o que é verdadeiro e falso, o que é correto e incorreto, enfim, o que é bom e ruim. Já o desejo (orexis) é a capacidade de nos mover na medida em que ele é um movimento (kinesis) ou atividade (energeia) de nossa alma que se realiza no corpo em direção ao que lhe falta, ao objeto desejado. ${ }^{43}$ Mesmo sendo um movimento da parte não racional (alogon) da alma, ele pode ser orientado pela razão, isto é, ele pode seguir o que a razão discrimina como sendo bom. ${ }^{44}$

O desejo, por ele mesmo, não é capaz de saber se o objeto desejado é bom ou ruim, se nos leva para uma ação viciosa ou virtuosa, ou mesmo para aquela que está fora do campo da moral: a ação bestial. A avaliação do que é bom ou ruim, do que deve ser desejado ou não, só pode ser feita pela razão. Ora, é por ter em mira o bem que o temperante orienta seus desejos corretamente sobre o que se deve, como e quando se deve ter apetite. Sendo assim, apenas por meio da reta razão podemos ter bons desejos. Eis o modelo do temperante:

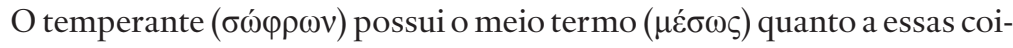
sas <isto é, os prazeres do tato e do paladar>. Ele não sente prazer com o que mais sente o intemperante, mas antes o desgosta; nem em geral com o que não deve, nem em nada excessivo. Quando lhe faltam, ele não sente dor ou apetite por eles, ou sente moderadamente, não mais do que se deve, nem quando não se deve, nem em geral nada disso. Com efeito, ele deseja prazeres que conduzam à saúde e ao bem-estar de modo moderado e como se deve; e deseja outros prazeres, uma vez que estes não impeçam a saúde e o bem-estar e que não sejam contrários ao belo ( $\pi \alpha$ à̀

42 Cf. Met. IX, 2, 1046a36-b28.

43 Depois de dizer que o movimento implica três coisas: aquilo que move, aquilo que move e é movido, e aquilo que é movido, Aristóteles define o desejo da seguinte maneira: "Aquilo que move sem ser movido é o bem prático, aquilo que move e é movido é a faculdade desiderativa (to orektikon) (pois aquilo que é movido assim o é na medida em que deseja, e o desejo (orexis) é um movimento ( $k i$ nesis) ou atividade (energeia)), e aquilo que é movido é o animal” (DA III, 10, 433b15-18). O termo desejo refere-se a orexis, gênero de três espécies de desejo: querer (boulêsis), ter apetite (epithumia) e ter impulso (thumos).

44 Cf. ENI 13 e VI 2, 1139a27. 


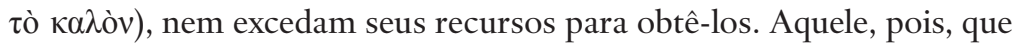
negligencia essas coisas, estima mais tais prazeres do que eles mereçam;

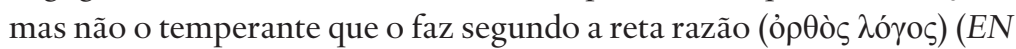
III 11: 1119a12-21).

Como vemos, no caso do temperante, a parte apetitiva está em harmonia (symphôneîn) com a razão, pois o temperante é aquele que persegue os prazeres devidos e assim o faz segundo a reta razão. Conduzido pela razão, ele não deseja os prazeres acima do que se deve. Assim, tendo como modelo o temperante, podemos concluir que o desejo, sobretudo o apetite, deve ser conforme a razão, seja por obediência, seja por estar em harmonia com ela. Quando a parte não racional (alogon) obedece à racional - e assim deve ser, pois a parte racional direciona corretamente e conduz para as melhores coisas,$-{ }^{45}$ os fins desejados são verdadeiramente bons fins. Com efeito, o filósofo continua mais adiante:

Os apetites devem ser moderados e poucos, e nunca oporem-se à razão - isto é o que chamamos de ser disciplinado ( $\varepsilon \dot{\pi} \pi \varepsilon 1 \theta \dot{\varepsilon} \varsigma)$ e comedi-

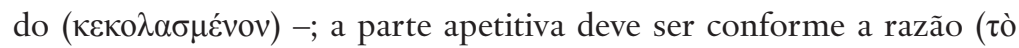

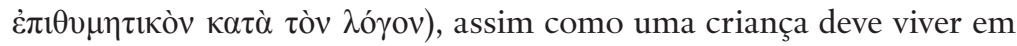
obediência ao seu tutor. Por isso, é preciso que a parte apetitiva do temperante esteja em harmonia com a razão ( $\tau$ ò $\dot{\pi} \pi \imath v \mu \eta \tau$ เò̀ $\sigma 0 \mu \varphi \omega v \varepsilon \tilde{v} \tau \tilde{\omega}$ $\lambda o ́ \gamma($ ), pois ambas têm como alvo o belo e o temperante é aquele que tem apetite com o que se deve, como e quando se deve, assim como ordena a razão (EN III 12: 1119b11-18).

O adjetivo "ser disciplinado" (eupeithes) da citação acima, ou seja, ser bem (eu) persuadido ou convencido (peithes) também pode significar ser convicto ou obediente. Portanto, a parte não racional, no caso do temperante, é bem obediente ou é facilmente persuadida pela racional. $\mathrm{O}$ adjetivo "ser comedido" (kekolasmenon) é um particípio derivado do verbo kolazô, que significa mutilar, podar, limitar, punir, reprimir, restringir, controlar; enfim, uma

45 Como diz Aristóteles: "que nós temos que agir de acordo com a reta razão (kata ton orthon logon) é um princípio comum e deve ser assumido" (EN II 2: 1103b33-34). No livro VI, é provável que o filósofo venha a corrigir esta tese ao estabelecer que nós devemos agir não kata logon, mas meta logou. Isso porque, nas palavras do mesmo, "a virtude não é meramente uma disposição conforme a reta razão (kata ton orthon logon), mas uma disposição com reta razão (meta tou orthoû logou)" (EN VI 13: 1144b26-27). Sobre este assunto, ver Zingano (2007b). 
pessoa que já foi limitada é aquela que possui limites quanto aos seus apetites, portanto, é comedida. A parte não racional, isto é, o desejo (orexis) deve ser, segundo o projeto aristotélico de educação moral, obediente e limitado ou controlado pela parte racional. A parte racional, por sua vez, deve persuadir e limitar toda e qualquer espécie de desejo, sobretudo o desejo pelo prazeroso, isto é, o apetite (epithumia).

Isso significa que uma pessoa que já seja virtuosa sabe o que é verdadeiramente bom e é facilmente persuadida a desejar e a achar prazeroso o que sua reta razão apreendeu como sendo bom. Por isso, o que o virtuoso julgar como sendo bom necessariamente lhe aparecerá como sendo prazeroso e também será objeto de seu desejo. O virtuoso, cujo desejo obedece à reta razão, terá bons prazeres ou prazeres naturais, enquanto o vicioso, cujo desejo não obedece senão ao seu próprio ímpeto de perseguir o prazeroso, terá maus prazeres ou prazeres antinaturais. Mas, afinal, o que o filósofo pretende dizer com esta classificação de prazer bom e natural e prazer ruim e antinatural? ${ }^{46}$

\section{O bom prazer}

Para compreendermos melhor o tipo de prazer que sente o virtuoso, não basta dizer que ele é moderado e que está em harmonia com a razão; temos, pois, que esclarecer o que Aristóteles denomina por prazer natural ou conforme a natureza. Não é de pouca valia recorrer mais uma vez a Alexandre de Afrodisia que, ao analisar a problemática do prazer na Ética Nicomaqueia, distingue com precisão o prazer antinatural do natural, a saber: o prazer natural é aquele que é próprio de atividades em conformidade com a natureza de cada ser vivo; portanto, segundo Alexandre, o bom prazer se identifica com o prazer natural. O prazer antinatural é prazer por homonímia e é próprio de atividades contrárias à natureza.

Bons prazeres são prazeres naturais desejados moderadamente. Ainda assim, persiste a indagação: como determinar os prazeres que são conformes a natureza? Sabemos que os que estão mais de acordo com a natureza humana, os que mais realizam a função própria (ergon) do homem - a racionalidade -, são aqueles próprios do homem bom. Mais uma vez chegamos ao mesmo ponto na ética aristotélica - não apenas para determinação do que é bom, mas também 
do que é prazeroso -, o critério último é o que é em si ou em absoluto. Há tanto o prazer em si (haplôs), como o prazer para si (hautôi $)^{47}$ e o que é prazeroso em si mesmo coincide com o que é prazeroso para o homem bom. O que não é em si prazeroso, também não o será para o homem bom, ainda que haja quem sinta prazer com tais coisas.

Mesmo sendo bons por natureza, tais prazeres devem ser buscados moderadamente. ${ }^{48}$ Ora, o temperante é justamente aquele que busca prazeres sadios na justa medida e no momento oportuno; nem mais, nem menos do que é preciso. O critério, portanto, para que um prazer seja bom é que ele seja conforme a natureza e que seja desejado moderadamente. Porém, para que não vigore um universalismo quanto aos bons prazeres, é preciso que tais prazeres naturais sejam considerados relativamente a cada um, pois são mais ou menos apropriados segundo as circunstâncias particulares. De fato, a ética aristotélica é antes particularista do que universalista, como bem sabemos e como também afirmou Alexandre de Afrodisia. ${ }^{49}$ Não seria adequado, nem deveras possível estabelecer uma categoria que liste os prazeres bons e os ruins, mas seria possível mostrar qual é a propriedade que nos permite generalizar e discernir o bom do mau prazer. Eis a propriedade geral: nenhum prazer natural é excessivo, portanto, não envolve dor. Ao contrário: todo prazer antinatural envolve dor por ser excessivo e tudo o que é excessivo é contrário à reta razão, isto é, àquilo que nos é mais específico e divino de nossa natureza.

Em concordância com a interpretação de Alexandre, podemos constatar que o Estagirita, em EN VII 14, estabelece clara distinção entre prazer natural (physei hêdea) e o que poderíamos chamar de prazer "antinatural". ${ }^{50} \mathrm{O}$ prazer

47 Como já fora explicado na seção "O hedonismo moderado de Aristóteles", do mesmo modo em que há bem em si e bem para mim, há prazer em si e prazer para mim. Cf. EN VIII, 2, 1155b21-3.

48 Sabemos que, segundo a ética aristotélica, a virtude é uma disposição para agir moderadamente, ou melhor, na justa medida com relação às emoções. Nas palavras do filósofo: "por disposições <entendemos> aqueles estados em função dos quais nos portamos (echomen) bem ou mal com relação às emoções: por exemplo, com relação ao encolerizar-se, se nos encolerizarmos forte ou fracamente, portamo-nos mal; se moderadamente (mesôs), bem, e de modo semelhante com relação às outras emoções" (EN II 4: 1105b26-29). Assim, a moderação com relação aos desejos e emoções é atributo essencial para ação e disposição virtuosas.

49 Cf. Alexandre de Afrodisia, Problema 5, 125, 24-28.

50 Além do prazer excessivo, próprio da disposição intemperante ou acrática, o prazer bestial também é considerado antinatural; porém, o primeiro encontra-se no campo moral, enquanto o segundo o extrapola. Sobre o prazer bestial, ver EN VII, 5, 1148b15-20. 
natural não envolve dor, pois não admite excesso, ${ }^{51}$ o que é evidente no caso da ação virtuosa. A ação virtuosa é prazerosa por natureza, portanto, não envolve dor psíquica; embora possa envolver dor física, como é tipicamente o caso da ação corajosa. Já o prazer antinatural ou contrário à natureza envolve dor. A dor aqui referida é o sofrimento causado pela sua ausência, pois não ter prazer é doloroso para quem o busca excessivamente. ${ }^{52}$

Também em EN VII 4, temos a distinção entre prazer por natureza (physei haireta), contrário à natureza (enantia) e intermediário ou neutro (metaxu). ${ }^{53}$ Aqueles que são desejados por natureza, e não de modo excessivo, são belos e bons, como "a vitória, a honra, a riqueza e outras coisas prazerosas do mesmo tipo” (1147b30). Os neutros são os prazeres necessários corporais que, em si mesmos, não são nem bons nem ruins, mas, se desejados excessivamente, tornam-se ruins; se moderadamente, tornam-se bons. Já os contrários à natureza são todos aqueles cuja fonte é ruim e/ou o modo de desejar é excessivo, portanto, são contrários à razão (para ton logon). ${ }^{54}$

Como vemos, Aristóteles concebe dois critérios para se determinar o valor moral de um prazer: um critério objetivo e o outro, por assim dizer, subjetivo. Dizemos que o critério objetivo é o valor moral de sua fonte, isto é, da atividade à qual pertence, independentemente do modo como o sujeito frui este prazer. Se ela for contrária à natureza, o prazer será antinatural e excessivo, portanto, moralmente ruim. Se ela for conforme a natureza, o prazer será natural e poderá ser bom se for desejado e fruído moderadamente. O critério pelo modo, excessivo ou moderado, de se desejar e fruir o prazer pode ser entendido como subjetivo, em distinção daquele outro, o objetivo. Temos, por um lado, o objeto de prazer, isto é, a atividade prazerosa, que determina objetivamente o valor moral do prazer, e, por outro, o modo de fruir este prazer, que determina subjetivamente o valor moral do prazer. Se o modo for excessivo, o resultado são prazeres ruins, mesmo que as atividades sejam, elas próprias, boas. Se o modo for moderado, o resultado é um bom prazer e isso apenas com relação às boas atividades, pois às ruins sempre se seguirão maus

51 Cf. EN VII, 14, 1154b15.

52 Cf. EN VII, 14, 1154a20-21.

53 Cf. EN VII, 4, 1148a22-b5.

54 Cf. EN VII, 4, 1148a29. 
prazeres, independentemente do modo de se desejar. Por exemplo, o estupro é uma atividade prazerosa para aquele que a exerce e em si mesma ruim, independentemente do modo de exercê-la, se excessivo ou moderado. Ou seja, não há como dizer que estuprar moderadamente seria bom. Neste caso, quando a atividade é ela própria ruim, o critério subjetivo fica excluído. Agora, quando a atividade é boa, por exemplo quanto ao beber vinho, o modo de bebê-lo, se moderado ou excessivo, deve ser aplicado.

Disso concluímos que o critério subjetivo vale apenas para os prazeres que já cumpriram o critério objetivo, ou seja, cuja fonte é conforme a natureza. Que os bons prazeres ou os neutros se tornam prejudiciais quando desejados de modo excessivo é evidente, afinal, "os homens não são censurados por experimentá-los, desejá-los ou amá-los, mas pelo modo, isto é, por excederem ( $\dot{\alpha} \lambda \lambda \grave{\alpha}$

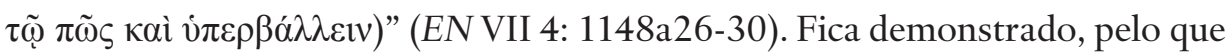
foi dito, que o erro moral concernente aos prazeres consiste no excesso, no contrário ao natural, ao racional, seja quanto ao objeto - à atividade prazerosa, seja quanto ao modo de se desejar esta atividade.

Parece ser também evidente, conforme o que foi dito, que aquele que age em vista do prazer e não em conformidade com a reta razão, age antes conforme a natureza animal do que a humana. Ora, é nítida a distinção da superioridade que Aristóteles atribui à natureza humana naquilo que justamente a diferencia da dos animais: a razão. Logo, seria baixo e vil agir conforme os apetites e contrariamente à razão, como fazem os descontrolados (akratês) e intemperantes (akolastos). Em suma, agir como um animal é agir contra a natureza humana, contra a razão, é tornar-se vicioso; ainda pior, é encaminhar-se para o limite do campo moral, campo este que define a própria essência do homem. Se a bestialidade e a divindade são os limites da humanidade, ${ }^{55}$ então, o vicioso está mais próximo da bestialidade, ao perseguir prazeres excessivos, e o virtuoso, da divindade, ao exercer bem o que há em nós de divino: a razão.

\section{Conclusão}

Podemos concluir que, como o virtuoso não age devido ao prazer, mas certamente com prazer, o prazer em absoluto jamais poderia ser o fim da ação virtuosa, mas sim a boa ação acompanhada de prazer natural e moderado. Com efeito, 
não é possível desejar o prazer simplesmente, pois que o prazer, ele mesmo, não existe em separado da atividade. Podemos desejar algo e este algo nos aparecer como sendo prazeroso, mas não podemos desejar o prazer. O prazer não existe como uma substância em separado, isto é, ele não subsiste por si mesmo. Ele é sempre um atributo que qualifica uma atividade como prazerosa. Ele mesmo não existe senão como uma qualidade que pertence a uma atividade quando esta nos parece ser prazerosa.

Assim, não apenas é impossível, do ponto de vista ontológico, desejar o prazer independentemente da atividade ao qual ele pertence, como também é impróprio, do ponto de vista ético, desejar uma atividade por ela ser prazerosa em preferência de ela ser boa. Como vimos, segundo o Estagirita, nós devemos desejar a ação virtuosa por ela mesma e não pelo prazer que lhe acompanha. Vimos também que o virtuoso deseja realizar a boa atividade e nunca o prazer acima dela. Neste sentido, desejar ter prazer não é senão desejar realizar certa atividade. Do mesmo modo, desejar ter bons prazeres não é senão desejar realizar boas atividades.

Esta concepção aristotélica de prazer parece não admitir que o bom julgamento dependa do que nos aparece como sendo prazeroso. Ao contrário, o que nos aparece como sendo prazeroso deve depender do bom julgamento, e assim ocorre no caso do virtuoso. Assim, tudo o que Aristóteles parece querer evitar é que nós tomemos o prazer e a dor como fundamentos do valor moral da ação. É possível, e, mais do que isso, é eticamente necessário que o bem seja feito não porque agir bem nos dá prazer, mas porque é o que é preciso ser feito, mesmo que não nos desse prazer. ${ }^{56}$

Como, no caso do virtuoso, é inevitável sentir prazer ao fazer o bem, certamente é preciso deixar claro que ele faz o bem com prazer e não devido ao prazer. Ele faz o bem devido ao próprio bem e por isso sente prazer. Fica patente que, em se tratando de uma pessoa virtuosa, o prazer é a consequência inevitável da ação virtuosa e não a sua razão. É possível e absolutamente imprescindível do ponto de vista ético agir bem sem ser movido pelo prazer, pois, do contrário, agiríamos sempre por causa de uma espécie de um prazer "egoísta”. Mas o virtuoso age virtuosamente por querer agir assim, e, ao mesmo tempo, acaba por 
sentir em mais alto grau o bom prazer, o prazer do virtuoso. Dorothea Frede expressou com agudeza o cerne inovador da concepção aristotélica de prazer:

Ela libera as ações moralmente boas de sua suspeita de esconder um egoísmo hedonista. Se ajudo alguém, segundo a explicação de Aristóteles, não o faço para obter, para mim, prazer pelo fato de estar ajudando, mas sim porque é a ação correta naquelas circunstâncias. E é por isso que ela me causa prazer. ${ }^{57}$

Podemos, portanto, concluir que a definição do prazer como um fenômeno cuja existência e natureza dependem inteiramente da atividade a qual pertence nos permite inferir que o juízo de valor que incide sobre a atividade é o critério de valoração moral do prazer, e não o contrário. Com efeito, é preciso que o bem em si mesmo seja também bom para aquele que ama o bem; assim como é preciso que o que é prazeroso em si mesmo seja prazeroso para o virtuoso, o que significa dizer que o virtuoso sabe desejar e sentir prazer conforme a reta razão. A operação desiderativa ideal é justamente aquela do homem bom, ou seja, aquela daquele que já habituou o seu desejo a ser conforme a reta razão, que aprendeu a desejar conforme o bom julgamento. Tornar-se virtuoso é passar a desejar e a sentir prazer com o que é bom por ser realmente bom, ao contrário do vicioso, que não faz senão desejar simplesmente o que lhe aparece como prazeroso. Eis a fórmula aristotélica que expressa a profunda e necessária relação entre prazer e virtude: o virtuoso apreende e deseja corretamente o que é bom e o que é bom necessariamente lhe aparece como prazeroso. 


\section{A educaçãa do desejo}

O melhor de todos é aquele que por si tudo compreende Bom também é aquele que se persuade por quem fala bem Agora, aquele que por si mesmo não compreende, nem o que de outro ouve lança no ânimo

Este, por sua vez, é um homem inútil

(EN I, 4, 1095b10-14)

\section{Introdução}

O desejo (orexis) é compreendido, por Aristóteles, como fazendo parte de nossa natureza, uma vez que o princípio do movimento não apenas está presente em nós (en hêmin), mas também está sob nosso poder (eph’hêmin) em certa medida. O ponto problemático para qualquer concepção ética é determinar qual seria essa medida, uma vez que ou bem se assume que o desejo está totalmente sob o nosso poder de modo que a razão seja ela mesma capaz de desejar e determinar diretamente o desejo por certos objetos, ou bem o desejo não está em nada sob o nosso poder, sendo absolutamente cego e surdo aos mandos da razão, ou bem haveria uma terceira via, um caminho do meio, ao que parece optar Aristóteles: o desejo está parcialmente sob o nosso poder, podendo ora ouvir e seguir a razão, ora ser surdo e contrário à razão. Quanto mais educarmos o desejo a seguir a razão, mais próximo estamos da virtude, do estado de harmonia e ausência de conflito. 
Em resumo, Aristóteles pressupõe que o desejo não é de uma natureza tal absolutamente avessa à racionalidade; ao contrário, ele é próprio de uma natureza que se compõe e participa da razão. E se compõe no sentido de poder ser regrado pelo que a razão determina como sendo verdadeiramente um bem. Isso significa que o desejo é educável e, mais do que isso, deve ser educado para que o homem possa realizar de modo perfeito sua natureza. Seria, portanto, incongruente à sua filosofia, dizer que o desejo é um obstáculo condenável a ser transposto ou extirpado da natureza; ou que haverá uma batalha incessante entre desejo e razão, não havendo jamais a possibilidade de se realizar a educação do desejo; ou que o desejo deva estar submisso de modo incondicional à razão, uma vez que ela seria capaz de determinar por si só a ação e esta seria a perfeita realização do dever moral.

Se, para a moral estoica e mesmo cristã, de modo geral, a afecção (pathos) é um impulso excessivo e desobediente à razão, isto é, um movimento da alma perturbador e contrário à natureza, ${ }^{1}$ para Aristóteles, ao contrário, o desejo é uma afecção (pathos) não racional que pode se harmonizar com a razão. Não apenas pode, como é preciso que assim seja. Desejo e razão, segundo o Estagirita, são inseparáveis assim como o corpo da alma, a cera do selo impresso, o mármore da estátua. Inseparáveis, todavia distintos. Por isso, mesmo desprovido ele próprio de razão, o desejo pode participar dela, e, por outro lado, mesmo a razão desprovida de desejo, ela pode participar dele. Isso significa que o desejo pode ser persuadido por aquilo que a razão diz que é correto. Não há, portanto, um problema propriamente psicológico, uma vez que não há nenhum impedimento oriundo da constituição da natureza humana, pois que ela é potencialmente capaz de realizar sua perfeita existência, a saber: a harmonia entre desejo e razão.

Assumamos, por enquanto, o que será arguido neste capítulo: a razão é capaz de atuar sobre a função desiderativa, seja incutindo bons hábitos ou promovendo o autoconhecimento, seja avaliando se o fim desejado é moralmente adequado ou não. Cabe investigarmos se ela seria capaz de determinar o fim da

1 Como vemos em Cícero, para Platão e Pitágoras, a cólera e o desejo são agitações que pertencem à parte da alma desprovida de razão e são contrárias e hostis à razão (Tusculanas, IV 5 10). Segundo o mesmo, Zenão dizia que o "pathos é um movimento da alma que obscurece à reta razão e que é contrário à natureza” (Tusc. IV 6 11). Também em Diógenes de Laércio, Vida e opiniões dos filósofos, VII 110: "Segundo Zenão, a afecção é um movimento da alma irracional e contrário à natureza, ou melhor, uma inclinação exagerada”. Sobre este ponto, ver Zingano (2007b, p. 167-211), "Deliberação e Vontade em Aristóteles". Ver também Lebrun (2002), O conceito de paixão. 
ação. Investigaremos, portanto, quais operações racionais atuam sobre o desejo no processo formativo do caráter e na constituição do fim da ação. Certamente, não basta falarmos da razão de modo genérico, pois é preciso compreender que operação racional pode atuar sobre o desejo e como ela pode atuar. Sabemos de antemão que não poderia ser a função contemplativa ou científica. Por isso, a racionalidade prática, aquela que tem como objeto a ação, parece ser o candidato mais adequado para esse papel. Sabemos também que ela é essencialmente deliberativa. Contudo, estaria ela reduzida à função deliberativa? Isso porque, se de fato estiver, o dilema da constituição racional do fim correto ficaria sem solução.

O que salta aos olhos quando lemos atentamente a Ética Nicomaqueia é que o filósofo enfatiza explicitamente que a operação deliberativa da razão diz respeito exclusivamente aos meios. Sendo assim, como poderia o desejo ser capaz de determinar o fim correto, se o bem só pode ser apreendido com verdade pela faculdade racional? Ademais, se o desejo, segundo Aristóteles, pode se tornar reto, ou seja, pode ser educado em termos de aprendizado (mathesis) e não de condicionamento mecânico (askêsis), ${ }^{2}$ então se pressupõe que a razão é de algum modo capaz de determiná-lo. Isso se confirma pelo fato de que o desejo, por natureza, não visa senão ao que parece ser prazeroso, mas, por educação, tornar-se capaz de ter como fim o que é verdadeiramente bom.

Enfim, devemos ter como pressuposto que a razão é de algum modo capaz de determinar o fim da ação para que a educação dos desejos e, consequentemente, o projeto da aquisição da virtude se sustente. Se a virtude moral é responsável pela constituição do bom fim, isso significa que, tratar do problema da aquisição da virtude moral implica conceber a constituição do fim virtuoso, isto é, do bom objeto de desejo. Para tanto, é preciso não apenas verificar a possibilidade de a virtude ser adquirida, mas também como tal possibilidade se realiza através da educação moral dos desejos. É preciso, portanto, explicitar por que tal educação é necessária para o projeto aristotélico da aquisição da virtude moral, pois se ela não for necessária, ou bem o desejo teria de ser naturalmente bom, ou ele deveria estar submisso de modo incondicional à razão. Contudo, em oposição às posições intelectualista e naturalista, a ética aristotélica não pressupõe que a razão seja autônoma o suficiente para determinar o desejo pelo

2 Askêsis não deve ser entendida aqui como prática, mas como uma espécie de condicionamento ou treinamento, como se diz da prática de exercícios físicos. O sentido de prática formadora pode ser encontrado em EN 1099b16, 1170a11-12. 
fim da ação segundo o conhecimento do bem e do mal, nem que ele seja dado por uma natureza inata boa ou má; porém, pressupõe que apenas a razão seja capaz de apreender o que é verdadeiramente bom.

Sendo assim, nossa tarefa é delimitar em que medida, segundo Aristóteles, a razão determina o desejo pelo fim. Para tanto, examinaremos de que modo o bom fim pode ser constituído tanto por uma razão capaz de apreendê-lo corretamente, como por um desejo capaz de tomá-lo como seu objeto, uma vez que o desejo já tenha sido habituado a ter prazer com o que se deve. Ao que tudo indica, a educação moral parece ser condição prévia necessária para que razão e desejo se harmonizem e a razão possa ser efetivamente causa coadjuvante (sunaitia) na constituição do desejo pelo fim da ação.

Traçado o nosso caminho investigativo, voltemos à dificuldade inicial, a saber, que operação racional poderia participar do desejo constituindo o seu objeto? Como a operação deliberativa da razão poderia determinar o objeto de desejo, uma vez que a deliberação (bouleusis) incide apenas sobre o que conduz ao fim e não sobre o fim propriamente?

A dificuldade reside tanto na determinação racional do fim, quanto na própria constituição da retitude desiderativa. Evidentemente, as questões são distintas, porém não estão desvinculadas na medida em que a determinação racional do fim bom só é possível se houver previamente a educação dos desejos. Uma coisa é procurar saber, no que diz respeito à ação, que operação racional outra que não a deliberativa é capaz de constituir o fim, pois sabemos que a deliberação determina exclusivamente os meios. Outra coisa é procurar compreender como a retitude desiderativa se constitui, isto é, que operação racional atua no processo de aquisição da virtude, portanto, na educação do desejo.

No intuito de solucionarmos tais dificuldades devemos pressupor que, no que concerne à determinação do fim, outra operação racional, que não a deliberativa, atua sobre o desejo. Porém, para que ela possa determinar de maneira eficiente o fim a ser desejado, é preciso que o desejo esteja previamente preparado, cultivado, habituado a desejar o que a razão julga como sendo bom. É preciso que a educação moral tenha se realizado para que o pensamento prático possa apreender o bem verdadeiro e o desejo possa tomá-lo como objeto, pois, como bem disse Aristóteles, "para o pensamento prático, a verdade deve estar de acordo com o desejo correto" (EN VI 2: 1139a31). Afinal, um pensamento sobre o que é verdadeiramente bom não poderia mover alguém se este não desejasse isto que é verdadeiramente bom. Em suma, investigaremos se nossos 
pressupostos estão corretos, a saber: se outra operação racional que não a deliberativa atua na constituição do fim e se a educação moral dos desejos deve ser condição de possibilidade para tal atuação.

Assim, para entender o que é a educação dos desejos é preciso compreender duas coisas: em primeiro lugar, o que é o desejo e suas espécies; em segundo lugar, como é possível educar o desejo, ou seja, como o desejo estaria, mesmo que parcialmente, sob o poder do agente? O que significa perguntar: qual operação racional e como ela atua sobre desejo educando-o? Antes de irmos às possíveis respostas, façamos o exercício de aprofundar o problema da apreensão do bom fim da ação.

\section{O problema da apreensão do bom fim}

Como a determinação do que é bom, segundo Aristóteles, está enredada na inexorável indeterminação do presente particular, sempre sujeito a toda sorte de variação contingente, é obscuro saber que fim é o melhor a ser desejado. Tampouco seria claro o vislumbre dos melhores meios para realizar um fim. Neste caso, contamos ao menos com a nossa habilidade de bem deliberar. Agora, com qual habilidade podemos contar para bem apreender o fim da ação? Certamente, precisamos aprender a ver, em circunstâncias sempre variáveis, qual é a melhor direção a ser tomada e apontarmos, como a um alvo, para o bom fim. Aristóteles é claro ao nos dizer que esta depuração da visão para bem acertar o alvo é fruto não apenas de elementos teóricos, como as opiniões e conselhos, as regras e as leis, mas, sobretudo, de uma habituação emocional ou desiderativa ao que é preciso desejar e realizar. $\mathrm{O}$ aprendizado, que pode ser expresso em termos de educação dos desejos ou aquisição das virtudes, ainda não nos responde uma incômoda pergunta: o que significa dizer que a virtude moral produz o alvo correto? Quais capacidades estão em jogo para que se constitua o bom fim a ser desejado? Trata-se, afinal, de um tipo de operação racional não deliberativa ou de um tipo de percepção que poderíamos chamar de percepção moral?

Posta a dificuldade, gostaria de iniciar esta breve apresentação com duas citações que irão localizar o problema da apreensão do fim da ação na Ética $\mathrm{Ni}$ comaqueia, de Aristóteles. Antes, é preciso deixar claro que irei me deter apenas na formulação do problema, deixando de lado qualquer tentativa de resolvê-lo, ainda que eu sinalize possíveis resoluções e aponte suas falhas. Passemos às citações: 
1. "Enquanto a virtude produz o alvo correto, a prudência (phronê-

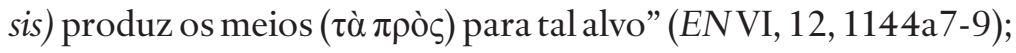

2. "O fim não é objeto de deliberação (bouleuton), mas aquelas coisas que conduzem aos fins" (EN III, 3, 1113b34).

Como podemos constatar, nessas duas citações, a virtude intelectual (phronêsis) é responsável pela correta apreensão dos meios, ou melhor dizendo, das coisas que conduzem ao fim, e a virtude moral (aretê êtikê), dos fins. ${ }^{3}$ Diante desta tese, e, diante de uma segunda tese que afirma que a função racional concernente às ações é essencialmente deliberativa, ou seja, que a razão prática parece se reduzir ao exercício de procurar os meios para realizar um fim previamente posto, Aristóteles lega à posteridade o problema da apreensão correta do fim da ação. Afinal, não poderíamos deixar de perguntar ao filósofo estagirita o que significa dizer que a disposição moral põe (tithênai) o fim?4

Como vimos, a primeira tese que apresentei é a de que a virtude produz o fim. Aristóteles a expõe ao procurar delinear a relação entre a prudência (phronêsis) - excelência da parte racional calculativa (logistikon) ou deliberativa ${ }^{5}-$ e a virtude moral (aretê êtikê) - excelência da parte não racional desiderativa (orektikon). ${ }^{6}$ Cito novamente o trecho: "a função do homem é exercida por completo conforme a prudência e a virtude moral: enquanto a virtude produz o alvo correto, a prudência, os meios para tal alvo" (EN VI, 12, 1144a 7-9). ${ }^{7}$ É preciso notar que ao dizer que a função do homem, isto é, a sua racionalidade se realiza por completo quando nossa alma se torna virtuosa intelectual e moralmente, o que o filósofo procura enfatizar é que a razão, do ponto de vista teórico e prático, deve ser desenvolvida maximamente e que, no que diz respeito à razão prática, a virtude intelectual é a excelência da capacidade racional de bem deliberar

3 Também na Ética Eudêmia, o mesmo é afirmado: "A virtude produz o fim correto (skopon orthon) ou as coisas em vista do fim? Nossa posição é que seja o fim, pois não há silogismo ou logos do fim. Em verdade, ele deve ser considerado como um princípio (archêe)" (EE II, 9, 1227b23-25).

4 EN III, 5, 1114b23-25.

5 EN VI, 1, 1138b35-1139a17.

6 ENI, 13, 1102b13-1103a10.

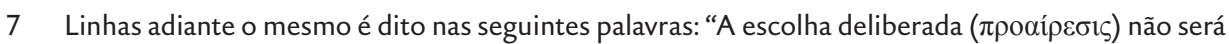
correta sem phronêsis e tampouco sem virtude: pois uma produz o fim e a outra o que conduz ao fim" (1145a5-7). 
os meios, enquanto a virtude moral é a excelência da capacidade racional de bem persuadir o desejo a desejar bons fins. Agora, como exatamente a virtude "produz o alvo correto" (ton skopon poieî orthon) não nos deixa explícito o filósofo, abrindo um flanco para as divergências.

A segunda tese que apresentei é a de que a razão prática parece ser essencialmente deliberativa, ${ }^{8}$ o que significa dizer que ela tem como objeto exclusivamente ou, sobretudo, os meios em vista de um fim. Isso se explica por dois motivos: em primeiro lugar, a deliberação (bouleusis) é definida como uma investigação sobre os meios, que se inicia com um fim já dado e termina em uma escolha (prohairesis), isto é, em um desejo por realizar o primeiro meio na cadeia daqueles que nos conduzem ao fim. ${ }^{9}$ Aristóteles é explícito ao dizer que a deliberação, bem como a escolha deliberada, se restringem à determinação dos meios que estão em nosso poder realizar. ${ }^{10}$ Como foi dito: "o fim não é objeto de deliberação (bouleuton), mas aquelas coisas que conduzem aos fins" (EN III, 3, 1113b34). ${ }^{11}$ Em segundo lugar, ao distinguir duas funções racionais elementares no início do sexto livro da Ética Nicomaqueia - a contemplativa (theôrêtikos) ou científica (epistêmonikon), responsável por contemplar os princípios invariáveis, e a prática ou calculativa (logistikon), responsável por calcular (logizesthai) e deliberar (bouleuesthai) os fatores variáveis e circunstanciais envolvidos na ação -, Aristóteles acaba por sustentar a tese de que a deliberação é a função racional prática por excelência.

Novamente, o problema pode ser descrito do seguinte modo: se o fim não pode ser apreendido pela deliberação, pois é objeto já dado a partir do qual se delibera, então ele seria fruto tão somente da disposição moral, isto é, de uma

8 Visto que a parte da alma que possui logos se divide em científica e calculativa e este última é essencialmente deliberativa EN VI, 1, 1138b35-1139a17.

9 EN III, 5, 1112b12-1113a14.

10 Como diz o filósofo estagirita: "o objeto de deliberação (bouleuton) e o objeto de escolha (proaireton) são o mesmo, com a ressalva que o objeto de escolha deliberada já está determinado: com efeito, o objeto de escolha deliberada é o que foi preferido em função do conselho" (EN III 3: 1113a2-5).

11 São muitas as passagens que dizem que o fim (telos/hou heneka) não é objeto de deliberação, mas apenas os meios (ta pros ta tele); cito apenas as mais significativas: EN III 2: 1111 b26-27; III 5: 1112b11-12; VI 4: 1140a27-28; VI 9: 1142b33 e ss; VI 13: 1144a7-9; EE II 10: 1226a7-17; Ret. I 6: 1362a18. Ver o artigo de Pierre Aubenque, "La prudence aristotélicienne porte-t-elle sur la fin ou sur les moyens? ” Revue des Études Grecques, 1965. Ver também, do mesmo autor, o capítulo dedicado à analise da prohairesis em seu livro A Prudência em Aristóteles, 2008. 
disposição (hexis) para se comportar de certo modo com relação às emoções (pathê). Diante dessa constatação textualmente explícita, porém filosoficamente hermética e obscura, os comentadores gastaram e continuam a gastar tinta e mais tinta no intuito de saber exatamente o que eu estou agora tentando saber: afinal, como o fim da ação é apreendido? Há ou não alguma operação racional na produção do fim? Tendo em vista o bom fim, como não poderia haver uma operação racional se apenas a razão é a faculdade capaz de discriminar o bem do mal? As respostas, como já eram de se esperar, divergem imensamente. Uns tratam tal silêncio que apenas sinaliza que a virtude produz o fim, embora não explique tal produção, como um absurdo (Broadie e Rowe); outros como um erro (Cooper, Hardie); ou como algo que deveria ser modificado (Greenwood); outros ainda como um lapso da parte de Aristóteles (Joachim). ${ }^{12}$

A divergência se encontra justamente na dificuldade de compreendermos como a disposição moral apreende ou produz corretamente o seu objeto: o fim. Se tal disposição diz respeito à parte não racional, desiderativa, da alma, então, poderíamos supor que o fim seria simplesmente um objeto de desejo, portanto, distinto de um objeto racional. O fim, neste caso, deveria ser compreendido como uma espécie de dado natural, ou seja, como se o fim surgisse em nossa alma "naturalmente". Digo naturalmente não no sentido de ele já estar presente em nossa alma desde o nascimento, como se fôssemos pré-determinados desde sempre a desejar certos fins, mas no sentido de o fim surgir mecânica ou espontaneamente, sem pensarmos, sem que pudéssemos ter controle imediato ou direto sobre ele, sem que pudéssemos constitui-lo deliberadamente. Bem sabemos, pela nossa experiência ordinária, que não basta dizer para si mesmo "vou desejar isto" ou "é melhor que eu deseje isto e não aquilo" para assim passarmos imediatamente a desejar. Ou seja, se o desejo não parece estar sob o domínio direto e imediato da razão, se não basta à razão ordenar para que o desejo obedeça, visto o caso do descontrole, acrasia ${ }^{13}$, então tampouco o fim, objeto de desejo, estaria sob o domínio direto da razão. Se nós não somos senhores por inteiro do modo como o fim nos aparece, então, como bem disse o filósofo, ${ }^{14}$ devemos

12 Cf. COOPER, 1986, p. 64; HARDIE, 1968, p. 213; BROADIE; ROWE, 2002, p. 49; JOACHIM, 1951, p. 218; GREENWOOD, 1973, p. 51.

14 Nas palavras do mesmo: "Se, portanto, como foi dito, as virtudes são voluntárias, somos também causas coadjuvantes em certo sentido das disposições e, pelo fato de sermos de certa qualidade 
reconhecer que somos parcial ou indiretamente senhores (kupioi) deste tipo de desejo capaz de direcionar nossas ações. O fim, ao contrário da ação, não está inteiramente sob o nosso poder (eph’hêmin). Ele é, essencialmente, fruto de uma parte não racional da alma.

Contudo, mesmo sendo fruto não da razão, mas do desejo, duas constatações devem ser feitas: em primeiro lugar, este desejo, quando educado, dialoga com a razão; em segundo lugar, há regularidade na sua ocorrência justamente porque somos capazes de adquirir uma disposição em desejar certos fins e não os seus contrários. Ou seja, com a repetição de ações, nos habituamos a agir de certo modo e não no seu sentido contrário. Haveria uma espécie de direcionamento para se desejar de certo modo, isto é, para que certos fins sejam produzidos em detrimento de seus contrários. Concebendo desta maneira, que papel teria a deliberação na produção do fim? Se tiver algum papel, certamente ele teria de ser exercido de modo indireto. Explico-me: como somos inteiramente senhores de ações voluntárias e, mais ainda, de ações escolhidas deliberadamente, e, como o hábito de repetir um tipo de ação engendra o tipo correspondente de disposição, então somos, por meio do pleno uso de nossa capacidade racional de deliberar, parcialmente responsáveis por certa regularidade no modo como o fim nos aparece. Em resumo, podemos dizer que, mesmo que a deliberação não tenha um acesso direto sobre a produção do fim, certamente, ela o tem por meio da determinação das ações que, uma vez tornadas habituais, engendram as disposições e, portanto, certas regularidades no modo pelo qual apreendemos o fim.

Antes de prosseguirmos, é preciso esclarecer que tipo de desejo interessa ao Estagirita no domínio ético, de modo que nos fique mais evidente em que sentido o fim é um objeto de desejo. Pois bem, no conjunto de nossos desejos, há aqueles que são por coisas impossíveis, como o desejo pela imortalidade, por exemplo. ${ }^{15}$ Há, porém, aqueles cujo objeto está em nosso poder buscar, como o

pomos (tithemetha) o fim que lhe corresponde. Os vícios também são voluntários, pois são similares” (EN III 5: 1114b23-25). Em seguida, continua Aristóteles: “As ações e as disposições não são voluntárias do mesmo modo; com efeito, de um lado, somos senhores (kupioi) de nossas ações do início ao fim, desde que conhecedores das circunstâncias; de outro, somos senhores do início das disposições, mas o acréscimo caso a caso não é distinguível, assim como ocorre nas doenças. Porque, porém, está em nosso poder (eph’hêmin) nos comportarmos assim ou não assim, por esta razão são voluntárias" (EN III 5: 1114b30-1115a3).

Exemplo dado em EN III, 4, 1111b20-2. 
desejo de se tornar virtuoso, e, esse tipo de desejo realizável é o que, do ponto de vista ético, interessa a Aristóteles.

Do desejo realizável, podemos distinguir dois tipos: um se refere ao fim de uma ação, e outro ao que conduz ao fim. O desejo pelo meio é chamado de prohairesis ou escolha deliberada. Com efeito, se desejamos certos meios para realizar certo fim, assim os desejamos não em vista deles mesmos, mas com vistas ao fim já dado. Por isso, na Ética Nicomaqueia, Aristóteles define brevemente a escolha deliberada como "desejo deliberado do que está em nosso poder (bouleutikê orexis tôn eph'hêmîn)” (EN III, 3, 1113a11), ou seja, um intelecto desejante (orektikos noûs) ou um desejo pensante (orexis dianoêtikê) (EN VI, 2, 1139b45), um desejo que se constituiu após e conforme a deliberação de realizar um meio com vista a um fim. ${ }^{16}$ Já na Ética Eudêmia a definição é explicitada com mais clareza: "Se, então, não se escolhe deliberadamente sem ter se preparado e deliberado se <algo> é pior ou melhor, e se se delibera sobre as coisas que estão sob nosso poder que podem ou não existir e que são meios para um fim, é evidente que a escolha deliberada é um desejo deliberado do que está em nosso poder" (1226b14-17). Adiante, conclui: "eu chamo de deliberado o desejo cujo princípio e causa é a deliberação e se deseja por haver deliberado” (122b20-21).

A escolha, portanto, é o desejo oriundo da investigação deliberativa, cujo objeto é um meio realizável aqui e agora em vista de um fim já dado. Sobre este fim já dado, a escolha não o constitui, mas apenas o aprova ou não. Por isso, temos primeiramente em nossa alma certo desejo que constitui o fim da ação, por exemplo, o desejo de ser saudável. Após a deliberação, surge outro desejo que

16 A frase em que se encontra tal definição é a conclusão de $E N$ III 3, capítulo em que se define deliberação: "Dado que o objeto de escolha deliberada é o objeto de desejo do que está em seu poder após a deliberação, a escolha deliberada será, então, o desejo deliberado do que está em nosso poder, pois, julgando em função de ter deliberado, desejamos conformemente à deliberação" (1113a9-12). Este desejo é pelo meio e não pelo fim. Este "desejamos" da frase é oregometha e não boulometha, ou seja, desejar é o gênero, que compreende a espécie escolha, por um lado, e, por outro, a espécie querer, apetite, impulso. Como diz Aubenque (2008, p. 196), "por certo, esta escolha é, ela mesma, um desejo (orexis), pois somente se quer os meios porque se quer o fim, e a escolha dos meios permanece subentendida à vontade do fim, sem a qual a escolha perderia toda razão de ser". Segundo Ross (1923, p. 207), porém, Aristóteles erra ao conceber a escolha como um desejo e limitar o seu objeto ao meio em vista de um fim; mesmo assim, segundo o autor, em todas as outras passagens em que ela não é discutida ex professo, ela é tratada como "intenção" ou "proposta" (purpose), portanto, como se dirigindo ao fim e não aos meios. Esta interpretação, todavia, obscurece a concepção aristotélica de prohairesis, com toda a limitação que ela possa apresentar diante da nossa concepção de "liberdade da vontade", como bem notou Aubenque (2008, p. 202-203). 
anseia concretizar os meios para tal fim, por exemplo, o desejo de se exercitar, dormir e se alimentar bem para ser saudável. Este desejo deliberado é o que Aristóteles chama de escolha. Já o desejo (orexis) que tem como objeto um fim se manifesta de três modos: o desejo pelo enfrentamento da dor, chamado impulso (thumos), o desejo pelo prazeroso, chamado apetite (epithumia), e o desejo pelo bem, chamado querer (boulêsis).

Pois bem, este desejo pelo fim pode ser ou não engendrado por uma disposição já adquirida. Quando ele é fruto de uma disposição, dizemos que a causa de assim desejar está parcialmente sob nosso poder, ou seja, podemos inferir que, sobre aqueles fins oriundos das disposições morais, temos controle parcial de sua aparição em nossa alma. Neste sentido, nossa razão deliberativa parece ser causa parcial ou indireta de alguns fins desejados. Se o que foi dito está correto, então a deliberação parece exercer um papel reduzido na determinação do fim, ensejando uma interpretação da ética aristotélica como uma ética antirracionalista, ${ }^{17}$ isto é, uma ética que valoriza o elemento desiderativo ou emotivo na apreensão do fim. ${ }^{18}$

Podemos dizer, grosso modo, que, enquanto a interpretação antirracionalista da ética aristotélica defende a tese de que o desejo é fortemente ou absolutamente avesso à razão, a interpretação racionalista afirma que o desejo, ou ao menos um tipo de desejo, seria fortemente ou absolutamente determinado pela razão a ponto de ele ser considerado um desejo essencialmente racional. É possível observar que esses dois caminhos interpretativos nos conduzem a um radicalismo, que, a meu ver, afasta de nosso horizonte uma concepção mais razoável desta problemática. Por um lado, o radicalismo da interpretação antirracionalista reside em afirmar que o objeto de desejo não é acessível à razão senão por via indireta, o que parece ser o caso quando se trata da função deliberativa da razão, mas não pode pressupor que a razão prática esteja reduzida à sua função deliberativa, visto que outra função racional teria de ser capaz de apreender o bom fim; por outro lado, a interpretação racionalista extrapola ao supor que haveria um tipo de desejo absolutamente racional, ${ }^{19}$ a boulêsis, que fosse capaz de desejar aquilo que lhe impõe direta e imediatamente a razão deliberativa.

17 Sobre a diferença entre a interpretação racionalista e a antirracionalista, ver Irwin (2007) "Rationalist v. Anti-rationalist Accounts of Virtue".

Jessica Moss (2011, p. 2) parece compreender deste modo a ética aristotélica. 
Evitaríamos, contudo, de nos enveredarmos para um dos extremos interpretativos se tivermos em vista não uma cisão ou oposição radical entre desejo e razão, nem uma subordinação ou redução do desejo à razão, mas tão somente uma distinção que permita a tão desejada harmonia entre ambos. Nem o desejo parece ser absolutamente avesso à razão, afinal, o filósofo afirma claramente que a razão pode participar do desejo persuadindo-o. ${ }^{20} \mathrm{Nem}$ a razão parece ser absolutamente determinante na apreensão do fim a ser desejado, pois, no que diz respeito ao desejo pelo fim, é preciso que algo apareça como sendo bom para se tornar objeto de desejo, o que pressupõe a atuação da imaginação (phantasia). ${ }^{21}$ Assim, é preciso se perguntar que razão ou que operação racional é esta responsável pela apreensão do bom fim. Certamente, como vimos, não poderia ser a operação deliberativa, pois que sua atuação é apenas indireta, como vimos. Todavia, quando se trata da disposição virtuosa, estamos falando da excelência da parte desiderativa da alma, portanto, do melhor funcionamento do desejo. Este pressupõe uma razão participante do desejo, isto é, uma razão capaz de participar do desejo persuadindo-o de que o bem apreendido verdadeiramente deve ser desejado.

Essa interpretação intermediária nos permitiria trazer à baila as nuances da complexa relação de participação e persuasão entre desejo e razão, além de ser bastante condizente com o que o filósofo afirma no capítulo 13 do primeiro livro da Ética Nicomaqueia, capítulo em que a divisão da alma é estabelecida com vistas a mostrar que a parte racional participa da não racional desiderativa persuadindo-a, e, a desiderativa participa da racional ouvindo-a ou obedecendo-a. Nas palavras do filósofo, "a parte < desiderativa > participa da razão, como dissemos; pelo menos, a do homem que se controla obedece à razão - além disso, presumivelmente a do homem temperante e corajoso é ainda mais obediente, pois em tudo concorda com a razão" (EN I, 13, 1102b26-29). Assim, a razão que põe corretamente o fim não é a deliberação, mas uma operação racional que participa do desejo persuadindo-o, tendo em vista que a virtude moral nada mais é do que o melhor funcionamento da nossa razão em acordo com o desejo, isto é, a melhor comunicação possível entre razão e desejo. Trata-se, portanto,

to um desejo da razão, o que ficou conhecido por vontade, é absolutamente inadequada.

Cf. ENI 13 .

21 Não cabe explicarmos a atuação da imaginação neste momento, mas esta tese foi desenvolvida pelo filósofo no DA III 9-11, De Motu 6 e 7 e EN III 4. 
de uma razão partícipe do desejo e não de uma razão desejante ou de um desejo pensante, como é o caso da escolha deliberada.

Se o filósofo não lhe forneceu um nome, isso não quer dizer, todavia, que não a concebeu e se tivéssemos que escolher um nome, este poderia ser razão persuasiva. Em poucas palavras, a razão que apreende corretamente o fim é aquela que o faz em uma comunicação harmônica com o desejo. Esta razão partícipe do desejo é capaz de constituir o bom fim fazendo uso da percepção das circunstâncias particulares, ou seja, é capaz de ver o que é realmente bom dada a situação particular, de modo que isso apareça como sendo bom para o agente moral, portanto, para o seu desejo. Com efeito, esta razão vê o que é bom a partir do material fornecido pela percepção, de modo que isto mesmo apareça (phainetai) como sendo bom, portanto, se constitua como objeto de desejo. Essa interpretação será mais bem desenvolvida ao longo deste primeiro capítulo.

Certamente, qualquer interpretação convincente terá que se defrontar com o que Aristóteles compreende por desejo, por razão, bem como a relação entre eles. A pergunta essencial, a meu ver, é a de saber se Aristóteles concede ou não à razão um papel crucial na apreensão do fim. ${ }^{22}$ Se a resposta for positiva, se de fato a razão for capaz de determinar direta e imediatamente o fim desejado, então devemos explicitar qual função racional é esta. Segundo a interpretação racionalista, o fim teria de ser apreendido por outra função racional que não a deliberativa, função esta que o próprio filósofo parece não ter explicitado em sua obra, Ética Nicomaqueia. Neste ponto, estou inteiramente de acordo com a interpretação racionalista.

Alguns comentadores ${ }^{23}$ fundamentam tal interpretação em uma passagem bastante difícil de ser compreendida da Ética Nicomaqueia, livro VI, capítulo 11. Trata-se de uma passagem inserida em um capítulo que Aristóteles pretende definir o termo gnômê (que pode ser traduzido por compreensão ou julgamento), e demonstrar quais são as quatro principais faculdades (dunameis) ou disposições (hexeis) intelectuais que o prudente deve possuir, a saber: prudência (phronêsis), entendimento (sunesis), julgamento (gnômê) e intelecto (noûs). Evidentemente, estas disposições próprias ao prudente são capazes de discriminar objetos sensíveis, mutáveis, contingentes, particulares, em uma só palavra: a ação

22 Irwin (1975), Wiggins (1980) e Cooper (1986) atribuíram à razão um papel essencial na apreensão do fim.

Por exemplo, Greenwood (1973, p. 51). 
a ser feita. Pois bem, a passagem que citarei diz respeito à atuação do intelecto (noûs) nos âmbitos teórico e prático. O noûs seria responsável tanto pela apreensão dos primeiros termos (horôn) do conhecimento teórico dedutivo, bem como dos princípios (archai) do que é em vista de algo, do fim (hoû heneka):

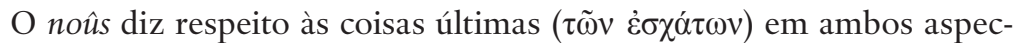
tos <isto é, no aspecto teórico e no prático>, pois tanto dos primeiros como dos últimos termos (horôn) há intelecção (noûs) e não raciocínio (logos); e o intelecto (noûs) que concerne às demonstrações apreende os termos imutáveis e primeiros, enquanto aquele que concerne às coisas práticas apreende <os termos> últimos e mutáveis e a premissa menor. Pois estes <termos> são os princípios (archai) do que é em vista de algo

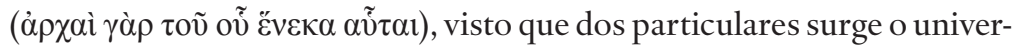
sal. Dessas coisas é preciso ter percepção, e esta é uma intelecção (noûs) (1143a35-b5).

Não nos cabe, no momento, analisar esta citação tão sintética e de difícil compreensão em seus detalhes, mas vale destacar o que nos interessa. A partir desta citação, não parece ser possível inferir que o intelecto ou a "intuição sensível” seja capaz de apreender o fim, embora possamos dizer que ele forneça as condições para tanto na medida em que ele apreende os objetos sensíveis, mutáveis e contingentes, isto é, os particulares. É preciso deixar claro que uma coisa é dizer que o noûs apreende os particulares a partir dos quais formamos o nosso juízo sobre o fim, outra coisa bem distinta é dizer que o noûs apreende o fim. ${ }^{24}$ Podemos, portanto, interpretar tal citação da seguinte forma: o noûs apreende o particular e esta apreensão é a condição inicial para apreendermos o fim. Ou seja, o particular apreendido é “o princípio do fim”, pois partimos da apreensão das circunstâncias particulares para que certo fim nos pareça bom e desejável.

Como vemos, esta citação não nos convence de imediato que o noûs seria o responsável pela apreensão do fim, pois uma outra leitura é mais plausível. A meu ver, as indicações textuais em que o filósofo trata da apreensão correta do fim na Ética Nicomaqueia são duas: (i) a primeira é aquela em que o Estagirita diz

24 Cooper (1986, p. 42), por exemplo, argumenta que Aristóteles esteja dizendo que os particulares são os princípios não da apreensão do fim (the grasping of ends), mas antes da obtenção do fim (the attainment of ends). Broadie (2002) faz leitura similar ao dizer que os particulares são os princípios do fim no sentido de que "eles dão nascimento ao fim (isto é, à sua realização) ao preencher um objetivo geral de modo a convertê-lo em uma decisão” (comentário ad locum). 
que a disposição moral põe (tithênai) o fim (EN III, 5, 1114b23-25), e (ii) a segunda é aquela em que ele diz que o fim é visto pelo virtuoso e não escolhido deliberadamente por ele, ou seja, o virtuoso vê (horan $)^{25}$ o que deve ser feito.

Bem sabemos que, segundo Aristóteles, a discriminação do que deve ser feito reside na percepção, ${ }^{26}$ pois a determinação do fim correto, do meio termo, deve ocorrer conforme as circunstâncias particulares que envolvem a ação. $\mathrm{O}$ fim, por sua vez, é a mais importante ${ }^{27}$ das circunstâncias particulares a serem determinadas conforme a ocasião (kata ton kairon). ${ }^{28}$ Por isso, ele também será objeto de discriminação sensível. E como qualquer outro objeto sensível, cuja natureza está sempre sujeita a mudanças, não é nada fácil apreendê-lo. ${ }^{29}$ Em poucas palavras: conceber um fim significa determinar o que é preciso ser feito aqui e agora diante das circunstâncias que se apresentam aos nossos sentidos. Desse modo, qualquer que seja a faculdade capaz de apreendê-lo, certamente ela será capaz de avaliar qual ação particular deve ser realizada e como deve ser realizada. Enquanto o fim é matéria de sensação, o meio é objeto de deliberação e escolha deliberada. Em suas palavras: "Também não são objeto de deliberação os particulares (kath’hekasta); por exemplo, se isto é pão ou se está cozido como se deve, pois são do domínio da sensação" (1113a1-2).

É evidente que a faculdade que determina o fim também não poderia operar simplesmente como uma discriminação sensível de um objeto particular, como o seu reconhecimento ("isto é um pão"), tampouco de uma qualidade sensível de certo objeto particular (“o pão está bem cozido”). Esta operação incide necessariamente sobre a ação, então ela deve ser capaz de avaliar que ação particular deve ser realizada e como deve ser realizada, portanto, que ação é boa e que ação

25 O virtuoso vê (horan) o que é bom a ser feito: EN III 4 1113a34 e vê corretamente (horosin orthos): EN VI 14 1143b14.

26 Cf. EN IV 5: 1126b5 e II 9: 1109b23. Por isso, acertadamente, Burnyeat (2010, p. 159) diz que "o nobre e o justo não admitem, segundo Aristóteles, formulações precisas em regras ou preceitos tradicionais [cf. I 3 1094b14-16; II 2 1104a3-10; V 10 1137b13-32; IX 2 1165a12-14]. É necessária uma percepção educada, uma capacidade que vá além da aplicação de regras gerais, para dizer o que requer a prática das virtudes em circunstâncias específicas”.

27 Cf. EN III, 2, 1111a16-18.

28 Cf. EN III 1: 1110a14 e 1111a19.

29 Com efeito, é difícil determinar o meio termo, assim como é igualmente difícil censurar aquele que se distância do meio termo, visto que "não é fácil determinar pela razão até que ponto e em quanto ele é censurável, pois tampouco o é algum objeto sensível: tais objetos ocorrem nos casos particulares e a discriminação é matéria de sensação (têi aisthêsei hê krisis)” (EN II, 9, 1109b21-3). 
é ruim. Dizer o que é bom ou ruim é tarefa exclusivamente da razão que, por sua vez, assim o faz a partir da percepção das circunstâncias. O fim é a ação a ser realizada a partir da apreensão do que deve ser feito aqui e agora e não a mera identificação de um objeto sensível.

Se, todavia, optarmos por dizer que o noûs é responsável pela apreensão do fim, então teríamos que definir, para além das palavras do filósofo, que tipo de operação o noûs exerceria nesta função e como ele se comunica com o desejo, visto que o desejo é o princípio motor por excelência. Se este noûs for um tipo de percepção, conforme nos indica a passagem de VI 11, restará ainda a tarefa de compreender como esta operação intelectual comunica o fim apreendido ao desejo: se de modo direto e imediato ou de outro modo. Se for de modo direto e imediato, então teríamos de supor a existência de um desejo puramente racional, um desejo que obedeça imediatamente ao que ordena a razão. Neste caso, a boulêsis aristotélica seria idêntica ao que conhecemos modernamente pelo conceito de vontade, o que é um ponto absolutamente controverso. Também teríamos que nos perguntar se o noûs que apreende o fim correto teria aprendido a fazê-lo por ensino ou por hábito.

Enfim, são várias as dificuldades que as interpretações racionalistas e antirracionalistas produzem. Contudo, mesmo que haja problemas com a interpretação racionalista, não poderíamos negar a necessidade de haver uma operação cognitiva na apreensão do bom fim, seja ela qual for: razão, percepção ou imaginação. Esta necessidade é evidente se nos atentarmos para a definição de desejo como a capacidade de nos mover na medida em que ele é uma atividade (energeia) de nossa alma, que se realiza no corpo em direção ao que lhe falta, ao objeto desejado. ${ }^{30} \mathrm{Ou}$ seja, a natureza da faculdade desiderativa é monolítica: ela nos conduz diretamente para o objeto desejado, sem ser capaz de, por ela mesma, ponderar se este objeto deve ou não ser desejado. Já a razão é a capacidade de distinguir contrários ${ }^{31} \mathrm{e}$ assim determinar o que é verdadeiro e falso, o que é correto e incorreto, enfim, o que é bom e ruim.

30 Depois de dizer que o movimento implica três coisas: aquilo que move, aquilo que move e é movido e aquilo que é movido, Aristóteles define o desejo da seguinte maneira: “Aquilo que move sem ser movido é o bem prático, aquilo que move e é movido é a faculdade desiderativa (to orektikon) (pois aquilo que é movido assim o é na medida em que deseja, e o desejo (orexis) é um movimento (kinesis) ou atividade (energeia)), e aquilo que é movido é o animal” (DA III 10: 433b15-18).

31 Cf. Met. IX 2, 1046a36-b28 e EN VI 2, 1139²1-31, onde o filósofo diz claramente que a função do pensamento, seja ele teórico ou prático, é apreender com verdade o seu objeto. 
Com intuito de apresentar o problema e as dificuldades das possíveis soluções, gostaria de concluir o texto retomando o que foi dito: conforme a primeira tese, não podemos saber com clareza como a virtude moral determina o fim e, conforme a segunda tese, sabemos com certeza que não é a deliberação que o determina. Se, porém, (i) o fim deve ser um bem prático, e, (ii) se não é função do desejo determinar o que é correto e incorreto, bom e ruim, mas de alguma operação cognitiva, então é preciso pressupor que haja um tipo de cognição que incida sobre o fim de modo a determinar corretamente a sua qualidade moral. Todavia, se a razão concernente às ações estiver reduzida à função deliberativa, ou bem haveria outra função cognitiva capaz de apreender o fim, como a percepção ou a imaginação ou alguma função racional, ou bem teremos que considerar como definitivamente aporético o problema da apreensão do bom fim segundo a filosofia moral aristotélica.

O ponto é que, a título de especulação, podemos inferir que a apreensão do bom fim pressupõe que a razão possa fazê-la e transmiti-la ao desejo. Sendo assim, a razão prática não poderia estar reduzida à deliberação, tampouco ser incomunicável com o desejo. Trata-se, ao que parece, de uma razão que avalia o que é bom a ser feito a partir da percepção das circunstâncias particulares, bem como persuade o desejo a desejar isto mesmo que parece ser bom a ser feito: o bom fim. Dizer, portanto, que a virtude moral põe o fim significa dizer que a razão em conjunto com o desejo apreende o bom fim. Há uma espécie de trabalho conjunto no caso do virtuoso: a sua razão apreende o bom fim e o seu desejo o deseja em vista dele mesmo, como vemos nas seguintes palavras do filósofo: "a função de toda parte do intelecto é apreender respectivamente a verdade e a falsidade, mas a do intelecto prático é apreender a verdade que está em acordo (homologôs) com o desejo reto" (Ética Nicomaqueia VI, 2, 1139³0-31).

\section{Objeção: o conceito de vontade}

Sabemos que a escolha é necessariamente uma operação racional desiderativa, pois é fruto de uma investigação deliberativa, já o desejo (orexis) é um movimento não racional capaz de ser persuadido pela razão. Tendo em vista que o objeto da escolha são os meios e o do desejo o fim, verificamos que não seria possível escolher direta e imediatamente desejar certo fim. Todavia, uma objeção pode ser apresentada, a saber, se atribuirmos a Aristóteles o papel de inaugurador do conceito de vontade, teríamos que aceitar tal possibilidade. 
Em outros termos, se fosse possível escolher o nosso ato de desejar certo fim, isto é, se a razão deliberativa tivesse inteiramente sob o seu poder o desejo pelo fim, então deveríamos admitir que a natureza não apenas da escolha, mas do querer (boulêsis) fosse de ordem puramente racional e que, desse modo, Aristóteles teria formulado, em sua ética, o que desde a Idade Média ficou conhecido como o conceito de vontade. ${ }^{32}$ Além dos medievais, o conceito de vontade fez fortuna entre os modernos e, como sabemos, continua imperante em nosso tempo. Sabemos que, para que haja liberdade, no sentido moderno do termo, é preciso haver um desejo que seja puramente racional ou uma faculdade racional que seja capaz de desejar de forma absolutamente autônoma, ou seja, é preciso haver o que se designa por vontade. Esse conceito pressupõe que o sujeito seja livre o suficiente para determinar racionalmente os fins de suas ações e não estar submetido a nenhuma espécie de necessitarismo imposto por um suposto mecanismo natural do desejo; caso contrário, a liberdade, no seu sentido moderno, ficaria comprometida. Pois bem, o conceito de vontade expressa a plena autonomia da razão sobre o desejo.

Se o desejo, pelo menos um tipo de desejo, a saber, o querer (boulêsis), não for ele próprio desprovido de razão, contrariando a natureza de seu gênero, ou seja, se o querer for uma espécie de desejo racional no sentido forte do termo, então esta seria, por sua vez, uma objeção de peso à tese aristotélica de que não é possível escolher deliberadamente o fim da ação. Isso porque, uma vez sendo de natureza racional, nada impediria que o querer fosse um modo de desejar da razão deliberativa, fazendo de Aristóteles um precursor do conceito de vontade. Ora, não é por acaso que a boulêsis será traduzida por voluntas no latim. ${ }^{33}$ Esta aproximação entre boulêsis e voluntas se explica pelo fato de o querer ser o modo de desejar mais afeito à razão. Há passagens tanto na Ética Nicomaqueia, como no De Anima, que parecem justificar a interpretação de que o querer não

32 Sobre este ponto, ver Irwin (1992). Também Gauthier (2002, p. 194, tomo II, grifo e tradução nossos), brevemente nos diz que, "para os escolásticos, a voluntas é precisamente um desejo racional no sentido de ele ser uma atividade da alma racional, que possui em si mesma uma faculdade desiderativa distinta da faculdade desiderativa irracional, ideia totalmente estranha a Aristóteles". Ross (1923, p. 207), ao contrário, defende que a noção aristotélica de escolha (prohairesis) é claramente uma tentativa de se formular o conceito de vontade. Sobre este ponto, ver também Zingano (2007b), "Deliberação e Vontade em Aristóteles".

33 Assim os estoicos traduziram o termo boulêsis. Como vemos em Cícero: "voluntas est, quae quid cum ratione desiderato (vontade é o que se deseja com razão)” (Tusc. IV 6 12). 
seria apenas mais capaz de ouvir a razão do que os outros dois tipos de desejo, mas seria ele próprio a expressão de uma razão que deseja. Analisaremos, em seguida, cada uma dessas passagens, pois é preciso conceber se a racionalidade atribuída ao querer é por participação ou por essência. Com efeito, se for por essência, isto é, se o querer for essencialmente próprio da parte racional, então não teremos senão o que os escolásticos chamaram de voluntas.

É bem sabido que a interpretação de Tomás de Aquino, retomando, por sua vez, a ideia agostiniana da escolha como um movimento ativo da vontade, consolida a tese racionalista de que a boulêsis aristotélica é um desejo próprio da parte racional da alma, portanto, uma vontade. Para o filósofo medieval, a vontade é "o desejo proveniente da apreensão de um objeto de desejo segundo o livre juízo. E tal é o desejo racional ou intelectivo que é dito vontade" (Suma Ia IIae q. 26a1). Por detrás deste conceito, há a crença de que somos agentes livres, no sentido de podermos escolher o que o nosso desejo irá desejar aqui e agora.

No fundo, o erro interpretativo consiste em confundir o ato de escolher realizar um desejo dentre outros com o ato de escolher o que iremos, neste momento, desejar. Escolher desejar é certamente distinto de escolher concretizar um desejo dentre vários outros, pois sabemos que é possível desejar sem ter que, necessariamente, realizar o nosso desejo. Seria, em verdade, contra intuitivo não fazer esta distinção entre desejar e satisfazer um desejo. Aristóteles nitidamente diferencia esses dois momentos, o do desejo e o da ação, atribuindo escolha apenas à ação. Podemos escolher agir, mas não desejar.

A responsabilidade moral incide exclusivamente na escolha por realizar ou não um desejo e de forma alguma na própria atividade de desejar, no próprio ato de desejar isto e não aquilo outro. Ou melhor, somos responsáveis por certos desejos recorrentes na mesma medida em que somos responsáveis pelas disposições que adquirimos, pois adquirimos voluntariamente as disposições a partir de ações voluntárias em certo sentido e não no seu sentido contrário. Ainda assim, não poderíamos precipitadamente dizer que os nossos desejos se reduzem àqueles postos pelas disposições adquiridas; por isso, a responsabilização por desejos eventuais ou não regulares é ainda menor do que aquela atribuída à disposição. De todo modo, é evidente que o desejo não está em nosso poder do mesmo modo que a ação. Como a ação pode ser escolhida deliberadamente, então Aristóteles nos diz que ela está inteiramente em nosso poder. Poderíamos dizer que o desejo está parcialmente em nosso poder, na medida em que está em 
nosso poder escolher o início da constituição do caráter. Discorreremos melhor sobre este ponto mais adiante. ${ }^{34}$

Ademais, o segundo problema da interpretação de Tomás de Aquino é identificar a vontade tanto com o querer, como com a escolha deliberada, uma vez que ela é tanto vontade do fim como dos meios. ${ }^{35}$ Aristóteles é claro ao dizer diversas vezes que o querer concerne ao fim e a escolha aos meios e que o querer (boulêsis) não é escolha deliberada. O desejo pelo meio será sempre uma decorrência do desejo pelo fim, pois o desejo deliberado nada mais é do que o impulsionador para a primeira ação que realizará o fim. Como vimos, desejar ter saúde é distinto de desejar aqui e agora caminhar para ter saúde. Ninguém escolhe direta e imediatamente desejar ter saúde, mas escolhe-se caminhar aqui e agora para realizar este fim. É preciso primeiramente desejar ter saúde para que se possa desejar os meios em vista deste fim. Ninguém deliberaria sobre os meios para ter saúde se não quisesse ser saudável; tampouco desejaria realizar tais meios. Ademais, devemos desejar os meios para realizar um fim porque este fim é realizável por meios adequados. Se a vontade, por sua vez, é identificada tanto com o desejo pelos meios, como com o desejo pelo fim, então ela é identificada tanto com a escolha deliberada como com o querer. Eis a contradição: se a vontade é o querer, logo ela não poderia ser também escolha deliberada, pois, para Aristóteles, querer e escolha são claramente distintos.

Por fim, Tomás de Aquino, ao atribuir a Aristóteles o conceito de vontade, comete duas extrapolações interpretativas, a saber: supor a existência de um desejo da parte racional, isto é, um desejo essencialmente racional e identificar, sob a rubrica da vontade, querer e escolha deliberada. Algumas passagens, todavia, podem induzir a esta leitura da boulêsis como voluntas, endossando a tese

34 Seção “O hábito", deste capítulo. Ver também Ética Nicomaqueia III 5: 1114b30-1115a3.

35 Tomás de Aquino é claro ao responder à questão sobre se a vontade incide apenas sobre o fim ou também sobre os meios em vista do fim: ela incide sobre ambos. Mesmo diante da objeção posta pela passagem da Ética Nicomaqueia 1112b3-4, à qual o próprio Aquinate se refere, a saber, que "a vontade (boulêsis) é do fim, enquanto a escolha é do que é para um fim" (Suma, la llae q.8ª); ele responde dizendo o seguinte: "se falamos de vontade referindo-se à faculdade, ela se estende tanto ao fim, como ao que é para um fim, pois toda potência se estende a tudo aquilo ao qual pode encontrar o aspecto de seu objeto; a vista, por exemplo, estende-se a tudo que participa de algum modo da cor. Por outro lado, o aspecto do bem (ratio autem boni), que é o objeto da faculdade da vontade se encontra não apenas no fim, mas também no que é para o fim" (Suma, la llae q.8²). Cf. também em Aquino (1993), Suma la llae q.12-13. Sobre este pondo ver Irwin (1992, p. 460). 
aquiniana, a saber: (i) Ética Nicomaqueia (EN) I 13 1102b29-1103a1; (ii) EN III 2: 1111b20; (iii) De Anima III 9: 432b4-7.

A primeira delas, 1102b29-1103a1, faz parte do capítulo 13 do livro primeiro da Ética Nicomaqueia, capítulo em que o filósofo descreve a estrutura da alma humana para que o político compreenda como a virtude pode ser engendrada em nossa alma. A passagem referida explica como a alma se divide de modo a garantir uma possível participação da razão na parte desiderativa:

É também manifesto que a parte não racional é dupla: o aspecto vegetativo em nada participa da razão. Ao passo que o aspecto apetitivo e, em geral, desiderativo participa de certo modo da razão ao lhe ser atentivo e obediente, assim como dizemos prestar atenção à razão do pai e dos amigos, mas não quando dizemos ter atenção na matemática. A advertência e toda censura e exortação indicam que a parte não racional é persuadida de certo modo pela razão. Se for preciso dizer que esta parte é racional, será também dupla a parte racional: uma propriamente e em si racional, a outra como capaz de ouvir em certa medida o pai (EN I 13: 1102b29-1103a1).

O trecho que mais nos põe em dificuldade, 1103a1, poderia ser traduzido da seguinte forma: "Se for preciso dizer que esta parte tem razão (to logon echon), então seria também dupla a parte que tem razão: uma propriamente e em si racional, a outra como que capaz de ouvir de certo modo o pai”. Devemos entender a expressão "ter razão" de dois modos: no sentido estrito de possuir ele próprio razão (no caso, o intelecto), e no sentido mais largo de possuir razão por participação (no caso, o desejo). ${ }^{36}$ Ou seja, se for preciso dizer que esta parte, a não racional, tem razão, então a parte desiderativa deve ser compreendida como tendo razão por participação e não por essência, pois, caso contrário, teríamos que supor que ela pudesse ser, sob o aspecto do querer, essencialmente racional. Esta é uma interpretação possível, e que me parece mais adequada, pois nega a suposição de que a parte desiderativa teria um aspecto absolutamente racional, a saber, a boulêsis.

Como a parte desiderativa é híbrida, isto é, tanto participa da parte racional como da não racional, ela deve ser considerada em sua duplicidade. Trata-se de

36 Sobre estes dois sentidos de "ter razão" (to logon echon), ver Stewart (1892, p. 167). Gauthier (2002, p. 98), por esta mesma razão, interpreta "ter razão" por "tomar ciência”. 
duas perspectivas possíveis para compreender a relação do desejo com as duas partes da alma. Se, por um lado, a tomarmos em relação à parte irracional, então ela deve ser considerada aquela que participa da parte racional, diferenciando-se da função vegetativa, que em nada participa da razão. Se, por outro lado, a tomarmos em relação à parte racional, então ela deve ser considerada aquela que é naturalmente desprovida de razão, mas que pode participar da parte racional, diferenciando-se da função intelectiva. Nas duas perspectivas, o que há em comum é que a função desiderativa participa da parte racional e é exatamente esse atributo que a define, diferenciando-a tanto da função intelectiva, como da vegetativa. Ou seja, o desejo é naturalmente um movimento da parte não racional da alma, portanto, ele é naturalmente desprovido de razão, mas capaz de participar da parte racional. Desse modo, acreditamos que Aristóteles não está preocupado em distinguir, nesta passagem, as três espécies de desejo para dizer que uma delas é essencialmente racional. Ele estaria antes procurando localizar o desejo em geral (haplôs oretiktikon) na alma humana diante da distinção das duas partes, a racional e a não racional. ${ }^{37}$

$\mathrm{O}$ argumento é bem preciso: trata-se de distinguir a parte racional da não racional e localizar a desiderativa como uma parte híbrida que pode ser dita de dois modos. A conclusão também parece ser clara: há uma função anímica absolutamente irracional, a vegetativa; outra função absolutamente racional, o intelecto; e ainda uma terceira função que é híbrida, o desejo. Este não é nem absolutamente racional, nem irracional, mas pode ser dito não racional por ser desprovido, ele próprio, de razão, ou pode ser dito racional na medida em que participa da razão; afinal, o desejo pode participar da razão ao ouvi-la e obedecê-la. ${ }^{38}$ Fica, assim, descartada a interpretação que, por sua vez, induziria ao erro de atribuir a Aristóteles o conceito de vontade.

37 Suscitar aqui, como fez Irwin (1992, p. 458-459), o problema de classificar os tipos de desejo conforme a bipartição da alma e propor duas soluções interpretativas, a antirracionalista e a racionalista, significa suscitar um falso problema para a interpretação desta passagem. Isso porque a classificação, por si só, é problemática ao sustentar fórmulas reducionistas de um conflito que requer antes uma explicitação da complexa relação entre desejo e razão do que a simples tomada de posição em preferência por uma das interpretações. Enquanto a interpretação antirracionalista defende a tese de que o desejo é absolutamente avesso à razão, a racionalista afirma a existência de um tipo de desejo que seria essencialmente racional. Diante dessas duas interpretações, optamos por nenhuma, pois o desejo é naturalmente tanto desprovido de razão como capaz de participar dela.

38 Em EE 1220b6-8, o filósofo também diz que "o caráter (êthos) é próprio da parte da alma não racional, mas capaz de ouvir a razão e ser conforme o que ela ordena”. Tomás de Aquino (1993, 
A segunda passagem, 1111b20, é aquela que afirma que o querer não é escolha deliberada, "embora lhe seja evidentemente afim (suneggus)". A passagem encontra-se no contexto em que a escolha deliberada é definida por exclusão dos possíveis candidatos. Depois de ter excluído a opinião, o apetite e o impulso, o filósofo argumenta pela exclusão do querer como sendo o definiens de escolha deliberada:

Tampouco é querer, embora lhe seja evidentemente afim, pois não há escolha deliberada de objetos impossíveis e, se alguém declarasse escolher deliberadamente coisas impossíveis, pareceria insano, ao passo que há querer de objetos impossíveis (por exemplo: a imortalidade). E o querer diz respeito também àquelas ações que de modo algum são realizadas por si mesmo (por exemplo: querer que um ator ou atleta vença a competição); ninguém escolhe por deliberação, porém, tais coisas, mas aquelas que crê engendrar por si próprio. Ademais, o querer diz respeito, sobretudo, ao fim, mas a escolha deliberada concerne ao que conduz ao fim (por exemplo: queremos estar saudáveis, mas escolhemos deliberadamente que coisas nos tornarão saudáveis; queremos ser felizes e o declaramos, mas não é apropriado dizer que escolhemos deliberadamente ser felizes). Em suma, a escolha deliberada parece dizer respeito àquelas coisas que estão em nosso poder (EN III 2: 1111b20-30).

Esta passagem nos permite dizer que o querer é antes distinto da escolha deliberada do que idêntico a ela, visto que a intenção de Aristóteles é mostrar por que a escolha não pode ser definida como nenhum dos três tipos de desejo, nem mesmo o querer. Apenas uma leitura que queira ver no termo afinidade ou proximidade (suneggus) o conceito de identidade proporia que o querer é um desejo da parte racional e, assim sendo, como interpreta Tomás de Aquino, tanto o querer (voluntas) como a escolha deliberada (electio) pertenceriam a uma mesma faculdade: à faculdade racional apetitiva, isto é, à vontade. ${ }^{39}$

§242) descreve com clareza esta passagem: “Uma parte da alma, a vegetativa, é irracional apenas. Outra parte é racional apenas, o intelecto e a razão. Ainda outra parte é em si mesma irracional, mas racional por participação, como a parte apetitiva e a desiderativa". Veja também que a solução dada por Zingano (2008), nota 1102b13-14, se aproxima do que acabamos de argumentar.

39 Como diz Tomás de Aquino (1993, § 443) em sua interpretação desta passagem: "Ele [Aristóteles] diz, primeiramente, que a escolha (electio) não é a vontade (voluntas), embora ela pareça estar intimamente vinculada à vontade. Ambos pertencem a uma única potência, ao apetite racional que é dito vontade. Mas a vontade designa um ato desta potência que concerne ao bem em absoluto. A 
Porém, na mesma passagem, Aristóteles ainda esclarece que querer e escolha não são os mesmos, pois não dizem respeito aos mesmos objetos: o querer diz respeito a objetos possíveis e impossíveis, e apenas aos fins; a escolha concerne apenas aos possíveis e aos meios. Querer e escolha, portanto, são distintos por terem objetos distintos. Ademais, podemos dizer que eles também diferem por natureza, pois o querer é desprovido de razão, já a escolha é um desejo que resulta da operação deliberativa da razão. E se eles são distintos, a sua proximidade explica-se apenas pelo fato de o querer ser o tipo de desejo mais capaz de ouvir a razão, ${ }^{40}$ e não porque querer e escolha sejam expressões de uma mesma faculdade volitiva racional. Sendo assim, dizer que o querer é o modo de desejar mais capaz de participar de razão está definitivamente distante da inferência de que o querer é um desejo da parte racional e que, portanto, ele definiria ou expressaria o ato de escolher. ${ }^{41}$

Outra frase deste mesmo trecho, 1111b20-30, à primeira vista problemática, é a seguinte: "o querer diz respeito sobretudo (mâllon) ao fim, mas a escolha concerne ao que conduz ao fim” (1111b25). O mâllon dessa frase pode conduzir a interpretações errôneas se a frase não for contextualizada. Aristóteles acabara de dizer que a escolha deliberada não é o querer pelo seguinte motivo: não há escolha deliberada de objetos impossíveis, embora haja querer de coisas impossíveis (por exemplo: a imortalidade). Também há querer de coisas que não estão em nosso poder realizar, como querer que um atleta vença uma competição, mas ninguém escolhe deliberadamente que ele vença, pois não há escolha deliberada

escolha designa um ato da mesma potência que concerne ao bem na medida em que ele pertence à nossa operação, pela qual nos ordenamos um bem".

40 Aristóteles é claro ao dizer no De Anima III 10 que "quando alguém é movido de acordo com a razão (kata ton logismon), ele também é movido de acordo com o querer (kataboulesin)" (433²425). Sobre a natureza da boulêsis, ver seção "Querer, impulso e apetite", mais adiante.

41 Além do Aquinate, esta também foi a interpretação dada por Aspásio, explicada e contra argumentada por Zingano: "Aspásio baseia-se em III 5: 1113a11-12, 'pois, julgando a partir do que foi deliberado, desejamos segundo o querer (75,10-11)', mas, como ele mesmo observa, há uma outra versão, que se conclui por kata ten bouleusin, 'pois, julgando a partir do que foi deliberado, desejamos segundo a "deliberação". Nesta segunda versão, Aristóteles não está dizendo que, mediante deliberação, o agente lança-se à ação por um querer, como se a escolha deliberada fosse interna (unicamente) ao querer, mas que, qualquer que tenha sido seu desejo (querer, impulso ou apetite, os três tipos de desejo), o homem, tendo deliberado, age segundo sua deliberação, realizando (ou não) o objeto de seu desejo" (ZINGANO, 2008, nota 1111b20). Analisaremos esta passagem, III 5: 1113a11-12, mais adiante. 
do que não está em nosso poder. "Além disso" (eti), ou seja, além das duas diferenças apresentadas, uma terceira é que "o querer diz respeito sobretudo ao fim e a escolha deliberada ao que conduz ao fim”. O mâllon da frase pode ser interpretado da seguinte maneira: (i) o querer não tem apenas como objeto o fim, mas também pode ter o meio, isto é, o querer diz respeito sobretudo (mas não exclusivamente) ao fim, ou, (ii) o querer não tem apenas como objeto o fim, isto é, um bem prático, portanto, realizável, mas também bens impossíveis, ou seja, que não se constitui como fim a ser atingido, mas apenas como objetos imaginários (como querer a imortalidade). Enquanto a primeira interpretação faz referência à frase seguinte, procurando distinguir querer de escolha deliberada ao dizer que o querer diz respeito sobretudo ao fim, embora possa ter como objeto o meio (embora, aparentemente, não haveria motivo para atribuir uma maior incidência do fim como objeto do querer e não o meio); a segunda interpretação faz referência ao conteúdo anterior, pois o querer incide no mais das vezes sobre fins realizáveis e não sobre objetos impossíveis que não poderiam ser fins de nossa ação. Neste ponto, concordamos com Stewart e discordamos de Zingano.

Stewart (ad locum) compreende que a melhor interpretação é a de que o mâllon diz respeito à frase toda, de modo que, assim, ficará evidente que o querer diz respeito exclusivamente ao fim (como vemos em 1113a15), ao contrário do que afirma a $E E$ (II 10, 1226a7-16). Tendo em conta essa saída linguística de Steward, a frase ficaria assim: "novamente, é mais correto dizer que queremos o fim e escolhemos o meio". Ou, podemos propor o que se segue: "Além disso, é sobretudo o querer que diz respeito ao fim, e a escolha deliberada ao meio", ou seja, não é exclusivo do querer ter como objeto o fim, pois o apetite e o impulso também incidem sobre fins. Já Zingano defende a outra interpretação ao dizer que "deve-se observar, no entanto, que a tese de Aristóteles não precisa limitar o querer ao fim, pois basta salientar que é sobretudo do fim, o que já o distingue da escolha deliberada; por outro lado, é conveniente não limitar o querer ao fim, pois pode ser também de um meio, na medida em que, sendo primeiramente de um fim, torna-se por intervenção da deliberação, querer do meio que realiza o fim. Quem quer os fins quer os meios que reconhece como adequado para realizar os fins" (ad locum). Ora, será justamente esta tese que fundamentará a assimilação da boulêsis ao conceito de vontade de Tomás de Aquino. O mesmo distinguirá vontade pelo meio e vontade pelo fim, estando a primeira subordinada à segunda. O ponto é que Aristóteles se esforçou por distinguir querer e escolha deliberada. Se dissermos que o querer também é pelo meio, nada impede a 
identificação, mesmo que parcial, do querer à escolha deliberada. É justamente isso que parece querer evitar Aristóteles. Não há intervenção direta da deliberação sobre o querer, mas sobre outro tipo de desejo, a prohairesis. Assim, quem quer os fins, escolhe os meios, sendo a escolha a expressão de um desejo deliberado, oriundo da deliberação. Ao contrário do querer que não é um desejo deliberado, pois que existe antes da deliberação e é a sua causa.

Outro argumento adicional é que seria definitivamente estranho à ética aristotélica supor um tipo apenas de desejo como sendo capaz de ouvir a razão e, mais ainda, como se ele fosse uma espécie de desejo da razão. Primeiramente, se já é um erro dividir a alma em partes ${ }^{42}$, seria, com mais razão, absurdo dividir a faculdade desiderativa, colocando o querer na parte racional, mas o apetite e o impulso na parte não racional; ou mesmo distribuindo o desejo em três partes, se reconhecêssemos três partes da alma, como fez Platão, em República, livro IV. Ao contrário, o desejo não se divide em partes, mas se diz de três modos, conforme a razão, o prazer e a dor, visto que o desejo (orexis) é tanto o querer (boulêsis), o apetite (epithumia) e o impulso (thumos). ${ }^{43}$

Este argumento adicional está presente na terceira e última passagem a ser analisada, DA III 9: 432b3-7, que, aparentemente, seria problemática, porém parece contar a nosso favor. Aristóteles, após criticar a partição da alma, mostrando a dificuldade que decorreria para classificar as funções da alma como pertencentes seja à parte racional, seja à não racional, passa a mostrar que a mesma dificuldade ocorreria com a faculdade desiderativa:

Além dessas < faculdades>, há a desiderativa, que parece ser distinta lógica e potencialmente de todas as outras. Certamente é absurdo distribuí-la em partes, pois o querer se engendra na parte racional e o apetite e o impulso na irracional. E se a alma fosse tripartida, o desejo estaria em cada parte (DA III 9: 432b3-7).

O trecho desta passagem que é mais avesso à nossa interpretação é aquele que diz que "o querer se engendra na parte racional e o apetite e o impulso na irracional (en te toi logistikoi gar he boulêsis ginetai, kai en toi alogoi he epithumia

42 Como diz Aristóteles em DA III 9: 432b3-7.

43 Cf. DA II 3: 414b2; III 9: 432b3-7; MA 6: 700b17-18; EE II 7: 1223a26-7; II 10: 1225b25-6; Ret. I 10: 1369a1-4 e EN III 2: 1111b11-2. Sobre a natureza de cada tipo de desejo, ver a seção "Querer, impulso e apetite", mais adiante. 
kai ho thumos)". Primeiramente, temos que considerar que esta afirmação pressupõe a suposição errônea, do ponto de vista da psicologia aristotélica, de uma alma bipartida em racional e irracional. ${ }^{44}$

Se a alma fosse partida, seja em quantas partes fossem, duas ou três; o desejo, assim como a sensação e a imaginação estariam distribuídos pelas partes e seriam, eles mesmos, partidos. Chegar a esta conclusão é, de fato, um disparate. Aristóteles, como sabemos, quer preservar a unidade do desejo em DA III 10: 433b10-11; por isso, justamente o que ele não quer é pressupor uma partição da alma e, consequentemente, do desejo. ${ }^{45}$ Sendo assim, como já não é correto pressupor a partição da alma segundo o projeto do De Anima, menos ainda estaria correto pressupor uma partição das faculdades anímicas, como a desiderativa. Ou seja, não parece ser razoável dizer que uma parte do desejo seria racional e outra desprovida de razão. ${ }^{46}$

Se tivermos que assumir como tese aristotélica que o querer se engendra na parte racional, então deveríamos interpretar esta tese não a partir da bipartição do desejo, mas a partir do fato de que o objeto do querer, o fim ou o bem, é sempre constituído pelo pensamento ou pela imaginação (se esta for entendida como um tipo de pensamento). O modo pelo qual o querer pode ter como objeto um pensamento ou uma imagem racional do que é bom será tratado em outro momento. ${ }^{47}$

Por fim, essas três passagens, se forem interpretadas como propusemos, confirmariam a tese de que o querer não pode ser assimilado ao conceito de vontade, pois esse tipo de desejo deve ser concebido como naturalmente desprovido de razão, visto ser esta a definição de seu gênero: o desejo (orexis). A sua diferença específica, por sua vez, é que ele é o tipo de desejo mais capaz de

44 Embora não seja errônea do ponto de vista político, como veremos adiante: seção "O hábito".

45 Esta é exatamente a interpretação de Ross (1961, p. 311-312) desta passagem.

46 Muitos intérpretes pressupõem que o querer é um desejo da parte racional, desconsiderando assim todo o contexto argumentativo no qual está inserida esta passagem. Assim o faz, claramente, Tomás de Aquino ao se referir ao querer como vontade: "a vontade é uma potência racional, pois está na razão, como é dito no livro III do De anima” (Suma, la llae q.8ª 1 ); além de outros, como Aristóteles (1993, p. 241) e Fortenbaugh (2006, p. 61-67).

47 Ver EN 1111b26, 1113a5, b3 e Ret. 1369b2-3. Vale a pena citar a interpretação de Nussbaum (1978, p. 335, tradução nossa) quanto a este ponto: "a observação de que ele está "in the logistikon" (Top, 126a12-13 e DA 432b5), e de que o movimento conforme a razão é um movimento conforme a Boulêsis (433a22) devem significar não que a Boulêsis seja um desejo mais o raciocínio de como atingir o objeto, mas um desejo por um objeto privilegiado, que deve ser posto pela razão". Esta questão será mais bem desenvolvida na análise dos tipos de desejos, a seção "Querer, impulso e apetite”. 
ouvir a razão, portanto, mais capaz de participar da função racional. O querer é um desejo por natureza obediente à razão; enquanto o impulso e o apetite são desejos por natureza menos obedientes à razão, mas educáveis para serem conforme a razão. ${ }^{48}$ Como o objeto do querer é o bem e a razão é a única operação anímica capaz de apreender corretamente o bem, o seu objeto será a apreensão racional sobre o que deve ser feito, ou seja, o querer é um modo de desejar conforme a razão; no caso do virtuoso, conforme a reta razão.

\section{Solução: é possível desejar corretamente}

Mesmo não sendo possível escolher deliberadamente o que iremos desejar, devemos compreender o que significa desejar conforme a deliberação (oregometha kata ten bouleusin) (1113a13).

Remontando a ordem que vai do fim à ação, podemos inferir que, diante de certo fim, investigamos os meios para realizá-lo. Uma vez concluída a deliberação, escolhemos realizar ou não este fim. Se for escolhido, então significa que o que havíamos desejado foi aprovado como sendo moralmente bom e realizável por bons meios. Isso não significa que constituímos o fim desejado a partir do que foi deliberado, mas que, ao concluirmos a deliberação e escolhermos realizar o fim, o nosso desejo foi avaliado como estando em conformidade com a deliberação. Nas palavras do filósofo:

Dado que o objeto de escolha deliberada é o objeto de desejo do que está em seu poder após a deliberação, a escolha deliberada será, então, o desejo deliberado do que está em nosso poder, pois, julgando em função de ter deliberado, desejamos conformemente à deliberação (EN III 5: 1113a11-12).

O desejo pelo fim é o início da deliberação, caso contrário, não se deliberaria sobre nada. Ora, a deliberação não é senão encontrar os meios para um fim

48 Certamente, o elemento ao qual se refere Aristóteles que é, por natureza, contrário à razão (para ton logou pephukos), que combate e puxa em sentido contrário à razão (ho machetai kai antiteinei tôi logôi) na alma dos controlados e descontrolados, é o elemento desiderativo que se expressa por meio do apetite (no caso da acrasia no sentido próprio) e por meio do impulso (no caso da acrasia por homonímia). Ademais, o filósofo cita a seguir que no caso do controlado é evidente que este elemento participa da razão, ou seja, o apetite; e mais evidente ainda no caso do temperante e do corajoso, respectivamente, o apetite e o impulso são mais obedientes, pois em tudo concordam com a razão, como veremos adiante. 
já dado. Uma vez concluída a deliberação e escolhidos os meios para se agir, passamos a desejar tais meios com vistas a realizar o fim desejado. Em suma, passamos a “desejar conformemente à deliberação". Esta frase, portanto, parece se referir ao desejo pelo meio, isto é, à escolha deliberada. Isso porque o fim desejado, uma vez escolhido, passa a ser realizável por meios encontrados pela deliberação. Se o próprio fim fosse objeto de deliberação, como diz Aristóteles, ${ }^{49}$ iríamos ao infinito e a deliberação seria vazia. Isso porque, se o fim fosse objeto de deliberação, então ele seria um meio para um fim que, por sua vez, seria um meio para outro fim e assim ad infinitum.

Do que foi argumentado até o momento, concluímos que à razão não cabe criar os próprios desejos, ${ }^{50}$ mas que o desejo pode apreender a desejar o que dita a razão e ser aprovado pela deliberação, portanto, escolhido. Desse modo, afirmamos haver a possibilidade de se desejar corretamente, o que significa dizer que o desejo, enquanto próprio da parte não racional da alma, pode participar da racional. Ou seja, ele é capaz de ser educado, de passar a ter como objeto com o que a razão lhe diz que é preciso ter.

Com efeito, para que o desejo seja educado, é preciso haver uma racionalidade capaz de educá-lo, visto que somente a razão é capaz de apreender verdadeiramente o que é bom. Tal racionalidade, no início da formação do caráter, é externa ao agente, pois a criança possui a razão apenas em potência;, mas com o caráter já constituído, ela passa a estar sob o domínio do agente. Esta racionalidade prática própria ao agente moral adulto possui, ao menos, duas funções essenciais: uma responsável pela apreensão dos meios, a deliberativa, e outra

49 "Parece, então, conforme foi dito, que o homem é princípio das ações; o conselho concerne às coisas feitas por si mesmo; as ações são em vista de outras coisas. Portanto, não é objeto de deliberação o fim, mas as coisas que conduzem aos fins [...]. Se sempre se tiver que deliberar, se irá ao infinito. O objeto de deliberação e o objeto de escolha deliberada são o mesmo, com a ressalva que o objeto da escolha deliberada é o que foi preferido em função do conselho. Cada um para de investigar como agirá quando traz para si o princípio e ao seu condutor: é isto, com efeito, o que é objeto de escolha deliberada. Isto fica também evidente pelas constituições antigas, que Homero cantou em poemas, pois os reis anunciavam ao povo o que haviam escolhido por deliberação. Dado que o objeto de escolha deliberada é o objeto de desejo deliberado do que está em nosso poder, a escolha deliberada será, então, o desejo deliberativo do que está em nosso poder, pois julgando em função de ter deliberado, desejamos conformemente à deliberação" (EN III 3: 1112b32-1113a13).

50 Em concordância com o que foi argumentado, Zingano (2008, p. 2008, nota 1112b11-12) afirma que "a razão prática tem um papel fundamentalmente avaliativo, podendo interferir de modo a abortar o que conduz ao desejo, mas não cabe a ela criar os próprios desejos". E, continuando, "a razão parte de um fim posto pela disposição moral, ela não o gera puramente". 
que deve ser responsável pela apreensão correta do fim. Afinal, pressupõe-se que apenas uma operação racional pode apreender verdadeiramente o bom fim. Esta última, a título de distinção da função deliberativa e faux de mieux, nós a chamaremos de razão persuasiva.

$\mathrm{O}$ virtuoso é aquele que faz uso maximamente da racionalidade prática em ambas as funções, pois ele apreende verdadeiramente tanto o bom fim, como os bons meios. Por isso, que o desejo seja capaz de ser educado é evidente a partir da figura do virtuoso. Sabemos que, para nos tornarmos virtuosos, temos tanto que incutir o hábito de desejar o que se deve, o que significa ter prazer e dor com o que se deve, como também sabermos escolher deliberadamente os melhores meios para se realizar o fim desejado. ${ }^{51} \mathrm{O}$ virtuoso delibera sobre como e quando se deve realizar um fim já posto e correto; caso contrário, se a deliberação não partisse de um fim belo (kalos) e bom (agathos), não poderíamos dizer que a deliberação pudesse ser boa no sentido moral do termo. ${ }^{52}$ Portanto, para que um fim seja belo, o desejo deve ser educado a obedecer ao que a reta razão apreende como sendo belo. A virtude, neste sentido, não é senão a realização de bons desejos a partir de meios também moralmente bons. Trata-se de compreender a virtude como uma disposição para sentir emoções e desejos adequados de modo a permitir que o virtuoso aja conformemente à reta razão: ${ }^{53}$

Sendo assim, para sustentarmos a tese da possibilidade da retitude do desejo é necessário explicitar a condição desta possibilidade e a sua realização. Brevemente, a condição de possibilidade é garantida pela constituição natural da alma humana. E a realização desta possibilidade, pela educação do desejo.

\section{Condiẹão de possibilidade da educação do desejo}

A concepção aristotélica de natureza humana permite que haja a educação do desejo, pois, na alma, a parte desiderativa é naturalmente capaz de obedecer ou de ser persuadida pela parte racional, o que é explicado, em EN I 13, em termos

51 Ora, "é próprio da virtude ter prazer e dor com e como se deve" (EN IV 1: 1121 a4-5). Várias passagens atestam o fato de a educação consistir em ter prazer e evitar a dor com o que se deve, como e quando se deve. Faço referência apenas às mais significativas: EN II 3: 1104b4-13; 1105a4-13; X 1: 1172a22-23 e III 12: 1119b8-12.

52 Ver EN VI 9: 1142b27 e ss.

53 Ver EN II 6: 1106b36-1107a2 e II 9: 1109a20-25. 
de relação entre pai e filho. Ou seja, a razão pode participar do desejo orientando-o, como um pai em relação ao filho; e o desejo pode participar da razão, como uma criança obedece ao pai.

Segundo o Estagirita, a possível harmonia entre desejo e razão tem como condição a constituição natural da alma humana. Por isso, o fundamento da educação moral se encontra no fato de que a nossa natureza é educável, ou seja, o desejo pode ser capaz de ser persuadido pela razão que soube apreender que é verdadeiramente bom. Tendo isso em vista, a minha tese é a de que a educação do desejo não é apenas possível, como é de extrema importância para que a ação ética possa se fundar e se fundamentar na virtude.

Quanto à analogia entre pai e filho para explicar a relação entre razão e desejo, tendemos de imediato a considerá-la como uma explicação meramente metafórica. Porém, se notarmos bem, veremos que a explicação fundamenta-se no próprio processo formativo do caráter e, ao mesmo tempo, no amadurecimento da criança. No início, o desejo e o corpo são educados a partir de uma autoridade vinda de fora, mesmo porque, a criança, efetivamente, possui a faculdade racional ainda em potência; não podendo, por ela mesma, fazer uso de sua racionalidade tal qual o faz um adulto. A parte não racional precede à racional na geração do homem. A prova cabal disto é a de que o impulso (thumos), o apetite (epithumia) e o querer (boulêsis) pertencem à criança desde o nascimento, enquanto o raciocínio (logismos) e a inteligência (noûs) serão desenvolvidos com a idade. ${ }^{54}$ Portanto, por natureza, há precedência do desejo em relação à razão. Por haver esta precedência, Aristóteles pôde afirmar seguramente que "as crianças e os animais compartilham do voluntário, mas não da escolha deliberada” (EN III 1: 1111b8-9), ${ }^{55}$ e que "a escolha deliberada não é comum aos

54 “Como o corpo é primeiro do que a alma na geração, assim também é a parte que não possui razão em relação àquela que possui. Isto também é evidente, pois o impulso (thumos), o querer (boulêsis) e também o apetite (epithumia) existem nas crianças assim que são geradas, enquanto a natureza do cálculo (logismos) e da inteligência (noûs) surgem com o crescimento delas. Por isso, primeiro é necessário que a disciplina (epimeleia) do corpo preceda à da alma, e, consequentemente, a disciplina do desejo preceda à da inteligência; mas a disciplina do desejo é em vista da inteligência e a do corpo em vista da alma" (Pol. VII 15: 1334b18 -28). Ver EE II, 8, 1224a26-30, em que o Estagirita diz que a criança não age no sentido próprio do termo, como tampouco o animal, visto ainda não ter se apropriado do logos. Também em MM 1195b15, Aristóteles diz que "um filho é como se fosse uma parte do pai, até que ele atinja a maturidade e se separe dele. Desde então, ele passa a estar em uma relação de igualdade e paridade com seu pai".

55 Como sabemos, na $E N$, não é preciso que haja uma motivação estritamente racional para que o 
irracionais, apetite e impulso, porém, o são" (EN III 1: 1111b13-14). Ou seja, ao distinguir escolha do fim e desejo pelo fim, Aristóteles estabelece como sendo condição suficiente da ação o desejo de agir: princípio motor que está sob o poder do agente. Não é preciso raciocínio para agir, embora seja preciso para que os homens adultos possam agir corretamente.

\section{Realização da educação do desejo}

A dificuldade em saber como a educação moral dos desejos se realiza é a mesma que se apresenta ao buscarmos saber como, segundo Aristóteles, a prática de ações virtuosas engendra uma disposição virtuosa (hexis aretê). Sabemos que para adquirirmos uma disposição virtuosa devemos, primeiramente, praticar atividades similares (homoiôn energeiôn).$^{56}$ Não é gratuito o fato de o filósofo ter dito atividades similares àquelas propriamente virtuosas, pois, no processo de aquisição da virtude moral, tanto as disposições adquiridas são de qualidade similar àquela das atividades regularmente praticadas, como é preciso notar que uma atividade similar à virtuosa é aquela cuja qualidade é boa, embora o modo de ser feita não é propriamente virtuoso.

No processo de formação do caráter, devemos praticar ações virtuosas sem sermos propriamente virtuosos, justamente porque estamos habituando os nossos desejos a bem desejar e aprendendo a raciocinar de modo prudente ou com sabedoria prática (phronimos). Se, no início da formação, esta racionalidade prática ainda não foi plenamente desenvolvida, certamente a ação que o jovem realiza, quando boa, não será por uma decisão de sua própria racionalidade, mas a

agente seja princípio da ação no sentido forte do termo; ao contrário do que vemos na $E E$, em que o voluntário é concebido como um ato de reflexão, pois "não dizemos que a criança age, tampouco o animal, mas o que já age por raciocínio" (II, 8, 1224a28-30). Enquanto na EN, a condição para o ato ser voluntário é simplesmente que o princípio da ação esteja no agente e sob seu poder, ou seja, que ele não tenha vindo de fora exclusivamente, operando como uma causa mecânica necessária e coercitiva. Já na $E E$, o voluntário é associado com a noção de agir com reflexão, kata dianoia, embutindo já no voluntário a escolha deliberada. Neste sentido, podemos afirmar, sem hesitação, que é a Ética Nicomaqueia e não a Eudêmia que nos abre caminho para esta interpretação de que a razão não é capaz de criar os seus próprios desejos, distanciando Aristóteles do reduto ético calcado no conceito de vontade.

56 "Em uma palavra: as disposições originam-se das atividades similares, pois as disposições seguem as diferenças das atividades. Portanto, habituar-se de um modo ou de outro desde jovem não é de somenos, mas de muita, ou melhor: de toda importância" (EN II 1: 1103b23-25). Sobre a precedência da ação em relação à constituição da disposição, ver EN II 1-2. 
partir de uma autoridade externa, isto é, da força compulsória das leis ou regras morais ou da força persuasiva dos conselhos provenientes dos familiares e concidadãos. ${ }^{57}$ Por isso, podemos afirmar que, no processo de aquisição da virtude, o desejo vai se habituando a desejar bem e a razão vai aprendendo a ser reta.

As crianças, assim como os animais, possuem naturalmente disposições similares às virtuosas justamente porque elas não são capazes de agir com razão (meta logô̂). Porém, "uma vez de posse da razão (noûs), o agente difere por suas ações, e a disposição que antes era semelhante (homoia), agora é propriamente (kuriôs) virtude" (EN VI 13: 1144b12-14). Assim, em EN VI 13, Aristóteles nos explica que, se antes o jovem agia conforme a reta razão de outros, uma vez vindo a ser um adulto virtuoso, ele passa a agir com sua própria reta razão. Isso porque "a virtude não é meramente uma disposição conforme a reta razão (kata ton orthon logon), mas uma disposição com reta razão (meta tou orthoû logô̂)" (EN VI 13: 1144b26-27). ${ }^{58}$ No capítulo anterior (EN VI 12), Aristóteles distingue claramente aquele que faz ações virtuosas sem ser propriamente virtuoso, isto é, conforme a reta razão, daquele que o faz sendo propriamente virtuoso, isto é, com reta razão:

Como dizemos que as pessoas que fazem atos justos não são necessariamente justas, isto é, aqueles que agem cumprindo a lei, mas não de bom grado (akontas), ou por ignorância, ou por outro motivo e não em vista dos próprios atos (embora, certamente, eles fazem o que deviam fazer e fazem aquilo que o homem bom deveria fazer); assim, parece haver certo estado no qual o homem faz esses vários atos por ele ser bom, isto é, quando ele faz por escolha deliberada e em vista dos próprios atos (1144a14-20).

Sendo assim, dizer que o jovem se tornou um homem plenamente virtuoso significa dizer que ele se tornou capaz de realizar ações propriamente virtuosas, pois as realizará cumprindo três condições: (i) ele fornecerá as boas razões para realizar certa ação; (ii) ele escolherá deliberadamente realizar certa ação por ela ser virtuosa e em vista de ela ser virtuosa; e (iii) ele agirá de modo firme, sem hesitar, não apenas sabendo, mas também desejando agir de modo virtuoso. ${ }^{59}$

57 Ver EN X 9: $1179 \mathrm{~b} 30$ e ss. Sobre a autoridade paterna, ver 1180b4-7.

58 Sobre o agir conforme a razão e com razão, ver Zingano (2007b).

59 Cf. EN II 4: 1105a28-33. Como diz Burnyeat (2010, p. 161), "o objetivo último a que visa a prática 
Mesmo ainda sem sabermos como o desejo se torna reto, isto é, educado, sabemos ao menos que a educação do desejo é condição necessária e prévia para que a virtude moral possa ser adquirida, isto é, para que aquele que se tornou virtuoso possa agir segundo a boa escolha. Como foi dito, primeiramente nós aprendemos a desejar coisas boas, sem ainda sabermos dar por nós mesmos as boas razões para a escolha das ações. A partir da análise de EN X 9, capítulo dedicado sobretudo à educação moral, podemos inferir que a educação prévia do desejo é a condição para que o sujeito compreenda o sentido moral do que deve ser feito e, somente assim, possa tomar a boa decisão (1179b21-31). Por isso, do ponto de vista da formação do caráter, a educação do desejo precede e é condição necessária para aquisição plena da virtude, isto é, da virtude completa, que inclui a moral e a intelectual, a phronêsis. Mesmo que o processo de formação do caráter preceda a aquisição das virtudes morais e intelectuais, sabemos que é a atuação conjunta de desejo e razão, virtude moral e intelectual, que produz a ação propriamente virtuosa e, portanto, o homem virtuoso ${ }^{60}$. Isso porque, em termos gerais, tanto a virtude moral depende da intelectual, como a intelectual depende da moral, pois "é evidente, pelo o que foi dito, que não é possível ser propriamente bom (agathon) sem a prudência, nem ser prudente sem a virtude moral" (EN VI 13: 1144b30-32).

Que o conhecimento é causa necessária, mas não suficiente para a educação moral é evidente na concepção aristotélica. O limite do conhecimento para a aquisição da virtude se explica com clareza a partir do paradigma da ciência médica, pois "nós não nos tornamos mais capazes de fazer ações saudáveis e exercícios físicos por ter a ciência da medicina ou da ginástica” (ENVI 12: 1143b27). Ou seja, do mesmo modo em que a posse do conhecimento médico não é causa suficiente para nos tornarmos saudáveis, o conhecimento moral do bem tampouco o é do tornar-se bom. Afinal, "o conhecimento sobre essas coisas justas, belas e boas não nos torna mais capazes de fazer tais coisas, pois que as virtudes são disposições” (EN VI: 1143b23-25) e não faculdades ou formas de

do iniciante é que ele se torne o tipo de pessoa que faz <ações virtuosas>, escolhendo fazê-las em razão delas mesmas, agindo com base em um estado assentado de caráter".

60 Com efeito, certamente não é possível ser prudente sem que se seja temperante (cf. EN 1140b1219; 1103a16-17 e Pol. VII 15: 1334b15 e ss.). Como bem comenta Zingano (2007b, p. 379):: “O homem virtuoso precisa primeiramente ter os bons hábitos para então poder fazer operar em seu interior o ato racional que instaura a prudência". 
conhecimento, como queria Sócrates. Ou seja, é preciso que certa disposição em desejar o que é justo, belo e bom se constitua para que o conhecimento sobre essas coisas tenha alguma eficácia.

Salvo aqueles "bem-nascidos" que naturalmente amam o que é belo e bom, a razão não tem qualquer eficiência prática para a grande maioria comumente arrastada pelos apetites. Vale, então, para a maioria, a seguinte fórmula: como a terra que deve ser cultivada para receber a semente, o desejo deve ser cultivado para ouvir a razão. Em suma, é necessário que haja a educação do desejo para que a razão seja reta e tenha eficiência prática. Eis a passagem que sustenta claramente o que acabamos de dizer:

Alguns julgam que nos tornamos bons por natureza; outros, por habituação; outros ainda, por ensinamento. É evidente que o que é dado por natureza não está sob nosso poder (eph'hêmîn), mas, por certas causas divinas, existe naqueles que são verdadeiramente afortunados. Com efeito, o argumento (logos) e o ensinamento (didachê) certamente não têm poder sobre todos os homens, mas antes a alma de quem escuta deve ter sido cultivada previamente (prodieirgasthai) por meio de hábitos em regozijar (chairein) e odiar o que for belo, como a terra que deve ser nutrida para receber a semente. Isso porque aquele que vive segundo os afetos (pathos), não escutará nem entenderá o argumento que tenta dissuadi-lo; e, se assim for, como convencê-lo a mudar? Em geral, o afeto parece não ser dominado (hupeikein) pela razão, mas por força. É preciso, portanto, que o caráter possua de antemão certa familiaridade com a virtude, tendo amor pelo que belo (kalon) e ódio pelo que é vil. (EN X 9: 1179b21-31).

Como vemos na citação acima, a tese da precedência da educação dos desejos em relação à constituição da virtude parece se confirmar. É preciso que, na formação do caráter, o jovem adquira "hábitos em regozijar (chairein) e odiar o que for belo", ou seja, “é preciso, portanto, que o caráter possua de antemão certa familiaridade com a virtude, tendo amor pelo que é belo ( $k a l o n)$ e ódio pelo que é vil"; caso contrário, aquele que assim não tivesse seus desejos educados jamais conseguiria ouvir ou entender a razão. Por isso, tal educação parece ser condição prévia necessária para que razão e desejo se harmonizem e a razão possa também ser efetivamente causa na constituição do fim da ação. Assim, se, para Aristóteles, a habituação é o meio pelo qual a virtude pode ser adquirida, 
certamente ela não poderia ser uma dádiva divina ou natural, nem, como queria Sócrates, fruto de ensinamento.

Em suma, é necessário haver previamente um hábito moral concernente aos desejos para que a reta razão seja efetivamente causa conjunta da ação. É neste sentido, como vimos, que podemos afirmar que há precedência da disposição (hexis) em bem desejar a atuação da reta razão. Tal precedência é fundamental para distinguirmos a ética aristotélica da platônica, uma vez que, nesta última, a razão é a causa do verdadeiro desejo e, por conseguinte, causa necessária e suficiente da ação; enquanto que, para o filósofo, a razão só pode ser causa da ação propriamente virtuosa se estiver em acordo com o desejo. ${ }^{61}$

Sendo assim, podemos concluir que não apenas no âmbito da ação o desejo pelo fim antecede à escolha; também no âmbito da formação do caráter a educação do desejo é condição para que a razão seja capaz de apreender verdadeiramente o que deve ser feito e assim escolher deliberadamente os bons meios para agir. E verdadeiramente quer dizer não apenas ver o que deve ser feito (disso o vicioso também é capaz), mas persuadir o desejo a ter prazer com o que é correto, isto é, ver verdadeiramente significa apreender como bom e prazeroso isto aqui que deve ser feito agora.

Até o momento, sabemos da necessidade da educação dos desejos para a aquisição da virtude moral, resta examinarmos como tal educação se realiza. Para que o desejo se torne reto, isto é, para ele seja conforme a razão, Aristóteles nos diz suscintamente que ele deve ser educado a "ouvi-la" e a "obedecê-la”. ${ }^{62}$ Dizer isso significa pressupor que o desejo não nasce reto e que o fim não é naturalmente ${ }^{63} \mathrm{um}$ bom fim, mas que, ao contrário, deve ser constituído dessa forma. Se fosse naturalmente bom, não haveria por que educá-lo, ou seja, não haveria motivo ético para tanto, nem uma razão que fosse capaz de persuadir a parte desiderativa. Tampouco poderia haver educação do desejo se a parte desiderativa não fosse naturalmente educável, isto é, constituída, por natureza, para obedecer à razão.

61 Ver a passagem EN III 3: 1113a23-24, seguida do comentário de Zingano (2008). Grosso modo, se, para Platão, desejamos porque sabemos que é bom, para Aristóteles, diferentemente, desejamos porque parece bom, mesmo que saibamos que não o é. O virtuoso, por sua vez, age porque deseja o que sabe ser bom.

62 Termos utilizados em EN I 13: 1102b29-1103a3.

63 Ver também EN III 5: 1114b17-25. 
Basta dizermos, por enquanto, que ser educado é passar a se habituar a desejar o que é verdadeiramente bom a ser feito aqui e agora. O hábito (ethos), por sua vez, é incutido por repetidas ações; no caso, boas ações. Sendo assim, em princípio, realizamos boas ações sem desejá-las por elas mesmas, mas por uma autoridade externa, isto é, em vista de ser elogiado ou de evitar ser repreendido. Com o passar do tempo, passamos a ter vergonha de agir erradamente, pois esta autoridade externa começa a ser interiorizada; isso se explica pela necessidade pedagógica do pudor no processo de formação do caráter. ${ }^{64}$ Se, no início do processo formativo, o medo da punição pode, muitas vezes, fazer com que a criança evite fazer algo errado, certamente, com o tempo, esta criança deverá aprender a não agir mal pelas boas razões e não mais pelo medo de ser punida; ela passará, por hábito e por aprendizado, a não ter prazer com coisas ignóbeis e a se envergonhar caso venha fazê-las.

Entretanto, deve-se deixar claro que os procedimentos educativos não são assim tão explícitos e que eles decorrem, em alguma medida, de nossas inferências e suposições a este respeito. Isso porque não há, na Ética Nicomaqueia, uma explicação sofisticada e detalhada no que concerne ao modo pelo qual o desejo deve ser educado. Aristóteles apenas nos diz que o aspecto desiderativo da parte não racional da alma é naturalmente capaz de participar da parte racional, obedecendo-a, do mesmo modo que a razão é naturalmente capaz de participar do desejo, persuadindo-o, pois "a advertência e toda censura e exortação indicam que o aspecto irracional é persuadido de certo modo pela razão” (EN I 13: 1102b34-1103a1). ${ }^{65}$

64 Quanto a esta questão do pudor como um mecanismo de internalização da censura, ver, no próximo capítulo, seção "O pudor". Burnyeat (2010, p. 169) descreve com clareza este processo de formação: "a pessoa bem criada tem um tipo completamente diferente de razão para evitar as [ações ignóbeis]: na medida em que percebe que são injustas ou ignóbeis, essas ações não lhe parecem prazerosas; na medida em que não o percebe e, por conseguinte, deseja e, quiçá, faz tais coisas, sente-se mal a respeito, envergonha-se de seu fracasso. $\mathrm{O}$ sofrimento causado por suas ações é-lhes interior".

65 Quanto a esta passagem, Aspásio tem um comentário detalhado e curioso que diferencia a advertência (nouthetesis) da censura (epitimesis) e da exortação (paraklesis): "A censura (epitimesis) é um tipo de reproche (epiplexis) intenso que instila o medo com vistas a extirpar o impulso não racional; a advertência (nouthetesis) acompanhada de exortação é um reproche médio que ocorre no caso do erro. A exortação (paraklesis) é o encorajamento para as boas coisas, mas mais comumente um encorajamento em vista de qualquer coisa. Neste caso, nós compreendemos que a advertência é uma censura com exortação, salvo o fato de que toda advertência e exortação querem direcionar a parte desiderativa e impulsiva da alma para o que se deve quando ela se impulsiona ao que não de- 
Dizer que o desejo pode ser persuadido pela razão é bem diferente de dizer que ele seja fruto de uma escolha. Se pudesse ser fruto de uma escolha deliberada, então não haveria necessidade do hábito como uma prática formativa do desejo. Se fosse possível escolher que fim desejar, não haveria necessidade alguma de se educar o desejo e menos ainda de manter essa educação com a prática regular de ações virtuosas. É justamente em posição oposta ao naturalismo e ao intelectualismo que podemos compreender o desejo, a saber: o objeto de desejo enquanto fim da ação não é nem dado por uma natureza inata boa ou má, nem por uma razão autônoma o suficiente para determiná-lo segundo o conhecimento do bem e do mal. Desse modo, não podemos dizer que desde o início sabemos desejar retamente, mas que esta retitude é fruto de uma prática regular de boas ações que engendra esta disposição de bem desejar. ${ }^{66}$ Por isso, não só não é possível escolher deliberadamente o ato de desejar certo fim, como não faria sentido algum para a ética aristotélica se assim fosse possível.

Diante do que foi dito, a seguinte tese deve ser sustentada: não podemos escolher deliberadamente sentir certa emoção ou ter certo desejo, pois a razão deliberativa não determina o ato de desejar certo fim,${ }^{67}$ nem a emoção a ser sentida. Isso é evidente pelo que foi dito até aqui e também pela afirmação literal do filósofo de que nós nos "encolerizamos e tememos não por escolha deliberada (aproairetôs), ao passo que as virtudes são certas escolhas deliberadas ou não são sem escolha deliberada" (EN II 5: 1106a3-4). Isso se explica pelo fato de que "as virtudes e os vícios não são emoções (pathê), pois nós não nos dizemos ser bons (spoudaioi) ou maus (phauloi) conforme nossas emoções, mas conforme nossas

veria. <Mas isto não seria assim > se esta parte não fosse constituída por natureza de modo a obedecer à razão" (Aspásio, On Aristotle Nichomachean Ethics, 1-4, 7-8, trad. modificada a partir da tradução inglesa de David Konstan, Duckworth, Londres, 2006, 36,8-14). O filósofo estagirita parece exibir certa exatidão neste domínio ao falar que o grau de censura deve variar conforme o grau do erro seja menor ou maior (EN IV 5: 1126b7-9). Muitas outras passagens também dizem da educação por elogio e censura, faço referência apenas a algumas: EN II 9: 1109b14-20; III 5: 1113b22-26; III 12: 1118b35-1119b15; VII 4: 1148a26-30.

66 Sobre a prática de ações constituírem as disposições éticas, ver EN II 1: 1103a14 e ss.

67 São muitas as passagens que dizem que o fim (telos/hou heneka) não é objeto de deliberação, mas apenas os meios (ta pros ta tele), cito apenas as mais significativas: EN III 2: 1111 b26-27; III 5: 1112b11-12; VI 4: 1140a27-28; VI 9: 1142b33 e ss; VI 13: 1144a7-9; EE II 10: 1226a7-17; Ret. I 6: 1362a18. Ver o artigo de Pierre Aubenque, "La prudence aristotélicienne porte-t-elle sur la fin ou sur les moyens?", 1965. Ver também do mesmo autor o capítulo dedicado à analise da prohairesis em seu livro A Prudência em Aristóteles (2008). 
virtudes e vícios; nem somos elogiados ou censurados por nossas emoções" (EN II 5: 1105b29-32). A nossa ação, uma vez sendo realizada voluntariamente, é passível de elogio ou censura, portanto, imputável. No entanto, os afetos (pathê), isto é, o ato de sentir emoções e desejos não é direta e imediatamente elegível. Não podemos escolher ter ou não certo desejo ou sentir ou não certa emoção aqui e agora. Por isso, assim como nós não somos elogiados ou censurados por termos simplesmente certa emoção, mas sim por agirmos sem moderação conforme certa emoção, ${ }^{68}$ tampouco poderíamos ser elogiados ou censurados por termos simplesmente certo desejo, mas por realizá-lo ou não. ${ }^{69}$ Enfim, podemos ser completamente responsabilizados pelas nossas ações, uma vez que estas sejam voluntárias ou escolhidas deliberadamente, mas não pelos desejos.

Em resumo, podemos dizer que a educação dos desejos se realiza a partir de dois modos de atuação da razão sobre o desejo. Os dois modos são próprios da função persuasiva da razão, ou seja, são dois modos em que a razão atua persuadindo o desejo. O primeiro modo ocorre no período formativo do caráter do indivíduo, segundo uma racionalidade que lhe é externa, ou seja, através de conselhos, censuras e elogios dos pais e concidadãos. Assim é possível incutir na criança o hábito de bem agir e desejar. Trata-se de uma função essencialmente persuasiva e admoestadora.

Uma vez de posse da razão, o agente pode corrigir o seu caráter através da mudança de hábito, o que implica autoconhecimento. Isso porque, tendo bons hábitos e conhecendo a si próprio, o adulto pode educar seus próprios desejos. Neste caso, o segundo modo de atuação da razão parece ser primordialmente avaliativo e controlador. Ou seja, trata-se de uma função racional essencialmente persuasiva e corretiva. Sabemos que a razão é capaz de avaliar a qualidade moral do fim e dos meios, bem como aprová-lo ou reprová-lo, isto é, escolher realizá-lo ou não.

Em suma, não apenas a sociedade é capaz de educar os desejos das crianças, mas os adultos também são capazes de educar seus próprios desejos. Assim sendo, a educação do desejo é a via pela qual a razão atua sobre o desejo

68 Cf. EN II 5: 1105b29-1106a2.

69 Esta inferência pode ser sustentada por outras passagens exteriores ao capítulo 5 do livro II da EN, mas também se sustenta por Aristóteles ter se referido, neste capítulo, ao apetite (epithumia) e à cólera (orgê) correlata do impulso (thumos), como componentes de sua lista de emoções, sobre as quais não há escolha deliberada possível e, portanto, responsabilização por senti-las (1105b22). 
persuadindo-o, uma vez que, sem esta educação prévia, o desejo não é capaz de tomar como objeto aquilo que a razão determina como sendo um bem.

Para compreendermos melhor como a educação do desejo se realiza, ainda é preciso investigar mais detalhadamente o papel do hábito e do autoconhecimento, bem como o modo pelo qual a razão é capaz de persuadir cada tipo de desejo: o querer, o apetite e o impulso.

\section{O hábito}

Quanto ao hábito, cabe ainda falarmos o que se segue. Parece ser indubitável que tanto a razão em sua atuação persuasiva, como o hábito são responsáveis pela educação dos desejos. ${ }^{70}$ Vejamos o que o filósofo entende por hábito.

Aristóteles, na Retórica I 11, afirmou que o hábito é similar à natureza, o que ficou tradicionalmente conhecido na referência do hábito como uma espécie de segunda natureza. ${ }^{71}$ Se formos ao texto, veremos que o filósofo está investigando as causas da voluntariedade da ação. Ao descartar, das sete causas apresentadas (1369a7), o acaso (tuchê), a natureza (phusis) e a compulsão (bia), restam ainda quatro outras a serem investigadas: o hábito, a razão, o impulso e o apetite. O que nos interessa, porém, deste capítulo é compreender o que é o hábito e, portanto, qual é a semelhança e a diferença entre hábito e natureza. Se o que é feito por hábito é o que é feito de uma certa maneira muitas vezes, e o que é feito por natureza é o que é feito sempre, podemos compreender que a distinção entre hábito e natureza se encontra na frequência com que algo é feito. Isso porque "aquilo que é habitual é o que se tornou como que natural; pois o hábito é semelhante à natureza, já que a distância é pouca entre o frequente (pollakis) e o sempre (aei). A natureza concerne ao sempre e o hábito ao frequente” (Ret. I 11: 1370a5-9). Também no De Memoria, o Estagirita diz que “o hábito é já uma natureza” (452a28). Entretanto, sabemos que é "mais fácil mudar o hábito do que a natureza” (ENVII 11: 1152a29-30). Isso porque o hábito é algo adquirido pela prática de ações em um sentido e não no seu sentido contrário, logo, também pode ser corrompido pela falta de prática ou pela prática de ações no sentido contrário àquele que se

70 A importância de ambos, razão e hábito, na aquisição da virtude é atestada na Política, livro VII, $1334 \mathrm{a} 5$ e ss.

71 As divergências sobre esta concepção de hábito como uma segunda natureza foram pontuadas por Pierre-Marie Morel (1997) em seu texto “L’habitude: une seconde nature?”. 
está habituado. Eis a semelhança entre hábito e natureza: ambos determinam a regularidade de uma ação ou movimento, e a diferença: o hábito é uma mudança que se engendra por certa regularidade, enquanto a natureza é princípio interno de mudança sujeita a impedimentos extrínsecos contingentes.

Por isso, apesar de a disposição moral ser compreendida como uma espécie de "segunda natureza" por marca de sua regularidade e fixidez, ela jamais seria de ordem puramente natural. Nas palavras do filósofo,

Nenhuma virtude moral se engendra em nós por natureza, pois nada do que existe por natureza habitua-se a ser diverso. Por exemplo, a pedra, que por natureza se move para baixo, não se habituaria a mover-se para cima, nem mesmo se alguém tentasse habituá-la lançando-a milhares de vezes para cima (EN II 1: 1103a18-22).

Passar a se habituar a agir de certo modo é passar a achar bom e a ter prazer com as boas ações. Em verdade, é preciso se habituar a agir bem de modo a passar a ter prazer com as coisas que são boas, já que "o familiar e o habitual estão entre as coisas prazerosas, pois muitas coisas não são naturalmente prazerosas, mas o hábito as torna prazerosas" (Ret. I 10: 1369b18). Logo, se certas ações, no início, são feitas compulsória ou penosamente, com o tempo e prática regular, elas se tornam habituais e prazerosas. Como bem disse Burnyeat: "Aristóteles sustenta que apreender a fazer o que é virtuoso, torná-lo um hábito ou uma segunda natureza é, entre outras coisas, aprender a ter prazer - o prazer apropriado - em fazê-lo". ${ }^{2}$

Como sabemos, a prática regular de certas ações determina que as disposições sejam de certa qualidade. Aristóteles é explícito ao dizer que "a virtude intelectual tem gênese e aumento em grande parte pelo ensino (por isso requer experiência e tempo), ao passo que a virtude moral resulta do hábito” (EN II 1: 1103a15-17). ${ }^{73}$ Tornamo-nos tais quais nos habituamos a ser. Assim, por nos habituarmos a temer ou sermos corajosos, tornamo-nos corajosos ou covardes;

O mesmo ocorre no caso dos apetites (epithumias), assim como no caso das iras (orgas), pois se tornam uns temperantes e outros irascíveis, uns por persistirem a agir de um jeito nas mesmas situações, outros por

72 BURNYEAT, 2010, p. 166.

73 Cf. também EN II 2: 1103b31-32. 
persistirem de outro jeito. Em uma palavra: as disposições (hexeis) originam-se das atividades similares. Por esta razão é preciso que as atividades exprimam certas qualidades, pois as disposições seguem as atividades. Portanto, habituar-se de um modo ou de outro desde jovem não é de somenos, mas de muita, ou melhor: de toda importância (EN II 1: 1103b18-19).

Nessa citação, de suma importância para nossa reflexão, fica claro que é o hábito que engendra a disposição para agir de certo modo, portanto, para desejar de certo modo. Estão aqui contemplados os desejos não racionais, o apetite (epithumia) e o impulso (thumos). Este último é considerado como sinônimo de cólera (orgê). ${ }^{74}$ Vemos que tais modos de desejar são educados pelo bom hábito; o mesmo pode ser inferido ao querer (boulêsis), na medida em que ele, assim como os outros dois tipos, faz parte do gênero desejo (orexis). Como exatamente tais desejos são educados será examinado no decorrer desta investigação.

Que as disposições engendram-se por ações ficou evidente. O que não parece tão evidente é como os desejos se engendram a partir das disposições. Analisemos uma passagem que demonstra que nós somos inteiramente senhores de nossas ações e, uma vez que as disposições são constituídas por ações repetidas, podemos dizer que somos parcial e indiretamente senhores de nossas disposições. A passagem mostra que são as disposições que põem (tithênai) os desejos:

Se, portanto, como foi dito, as virtudes são voluntárias, somos também causas coadjuvantes em certo sentido das disposições e, pelo fato de sermos de certa qualidade pomos (tithemetha) o fim que lhe corresponde. Os vícios também são voluntários, pois são similares (EN III 5: 1114b23-25).

Desta citação, cabe enfatizar que Aristóteles apenas utiliza o verbo pôr ou dispor e jamais escolher o fim. Contudo, não nos esclarece o que significa dispor um fim, como isto ocorre, por qual faculdade; embora, como vimos, não poderia ser, por inferência, outra senão a razão quando se trata de um bom fim. Certamente, esta investigação é mais apropriada para o tratado psicológico, o De Anima, e para os psicofísicos, os Parva Naturalia e o De Motu Animalium.

74 Sobre este ponto, ver a seção “Querer, impulso e apetite”, mais adiante. Ver também o artigo de Frère (2000), “Emportement et colère: thumos et orgè selon Aristote”. 
Para a disciplina ética não é necessário que se tenha um conhecimento das operações psicofísicas determinantes da ação; basta que se saiba o suficiente sobre a alma humana para que o político ou o legislador possa engendrar as virtudes nos cidadãos. ${ }^{75}$

Sendo assim, basta que o político conceba a alma como um objeto de investigação ética, ou seja, que ele saiba que a alma humana, aparentemente, possua duas partes, uma racional e outra desprovida de razão. Esta não seria uma inverdade, mas apenas um modo não tão rigoroso de tratar a natureza da alma, ou melhor, com exatidão distinta daquela do exame do verdadeiro físico. Basta saber que são distintas a função desiderativa e a racional (o que é o mesmo que dizer, porém em termos menos rigorosos, que são funções que pertencem a distintas "partes" da alma) para compreender que o desejo, embora desprovido de razão, seja naturalmente capaz de ouvi-la e que a educação do desejo signifique o perfeito equilíbrio, próprio à alma virtuosa, entre desejo e razão. Porém, para a ciência natural, que realiza uma investigação minuciosa da alma humana, a bipartição é problemática. ${ }^{76}$

75 Como diz Aristóteles: "deve-se evidentemente investigar a virtude humana, pois procurávamos o bem humano e a felicidade humana. Por virtude humana, entendemos não a do corpo, mas a da alma, e, por felicidade, entendemos atividade da alma. Se é assim, o homem político deve evidentemente conhecer de certo modo o que concerne à alma, assim como quem vai curar os olhos de alguém também deve conhecer de certo modo todo o corpo, e tanto mais deve conhecer quanto mais estimada e melhor do que a medicina é a arte de política: os médicos cultivados empenham-se muito no estudo do corpo. O estudo da alma deve ser feito também pelo homem político, mas ele deve estudá-la em função destes objetivos e tanto quanto for suficiente em relação ao que analisa, pois examinar com minúcia talvez seja por demais dispendioso para o que se propõe" (EN I 13: 1102a14-27). O comentário de Aspásio (2006, p. 34,34-35,5) a esta passagem reitera o argumento de que o estudo da alma deve ter apenas serventia prática, a saber, que o político possa tornar bons os seus cidadãos: "No caso, o político também deve conhecer a alma, se ele vai engendrar nela a virtude. Desse modo, nem o sábio, nem o cientista natural pensarão na alma com vistas às mesmas coisas que o político, pois o cientista natural conhece tudo sobre a alma em vista da própria contemplação e investiga o que concerne a ela exatamente, enquanto o político não o faz em vista da contemplação, mas referindo-se à virtude e em vista da virtude, e não é extremamente exato, mas apenas na medida do que for suficiente para ele adquirir o conhecimento < relevante $>$ da alma" (tradução minha a partir do inglês).

76 Em DA I 5: 411 b5-30, Aristóteles rejeita qualquer partição da alma com o argumento de que assim se justificaria uma partição arbitrária, problemática para localização das diversas funções anímicas e que assim se poderia dividir, se a alma fosse divisível, ao infinito. A unidade da alma tem de ser garantida em si mesma, caso contrário, se algo além da alma garantisse a unidade de suas partes, perguntaríamos se este algo é, ele próprio, divisível e, se não, o que garantiria a sua unidade e assim ao infinito. Com efeito, a tripartição platônica da alma será explicitamente criticada em DA I 5: 411b4- 
É também suficiente saber que, na prática, há conflitos entre o que diz nossa razão e ao que impulsiona nosso desejo. Se não fosse assim, não censuraríamos as ações provindas de emoções e desejos que são contrárias à razão, isto é, ao que consideramos racionalmente como um bem. Tampouco exortaríamos a bela harmonia entre desejo e razão que se expressa nas ações virtuosas. E se vemos que ora a parte desiderativa concorda com a razão e não há conflito, como no caso do virtuoso (spoudaios); ora a razão é instrumentalizada para a realização do desejo pelo prazeroso e não há conflito, como no caso do perverso (kakos) e do intemperante (akolastos); ora o desejo pelo prazeroso é refreado e controlado pela razão, como no caso do controlado (encratês); ora não é controlado, como no caso do descontrolado (acrático), e nestes dois últimos casos há conflito; então é possível concluir que esses fatos mostram, por eles mesmos, que a alma humana possui duas funções, a desiderativa e a racional, e que estas podem estar em harmonia ou em conflito. ${ }^{77}$ Com efeito, o conhecimento ético da alma deve servir à finalidade de compreender a possibilidade natural de se educar o desejo para engendrar a virtude.

Enfim, a finalidade de tal conhecimento é prática, qual seja: saber como e por quais causas a virtude pode ser engendrada na alma. Saber apenas o que é a virtude, como o fez Sócrates, retira toda praticidade própria ao conhecimento no domínio ético. Aristóteles critica Sócrates ao dizer que "ele costumava investigar o que é a virtude, mas não como e de quais fontes ela surgia” (EE 1216b1011; cf. 1216b19-22). Em Mênon de Platão, quando Sócrates é inquirido sobre se e como a virtude é adquirida (70a), ele responde que é impossível saber se e como a virtude é adquirida sem antes saber o que é a virtude (71a-b). Ora, mas se a virtude é conhecimento para Sócrates, conhecer é se tornar virtuoso. Evidentemente, Aristóteles critica essa doutrina socrática intelectualista com a sua concepção de hábito. Como ele próprio diz: "Sócrates pensou que as virtudes são operações racionais, pois todas são formas de conhecimento, mas, para nós, elas são com razão (meta logoû)" (EN VI 13: 1144b29-30)..$^{78}$

6 e em DA III 9: 432a25-26. Sabemos que a tripartição da alma em racional, apetitiva e impulsiva se baseia em uma primeira versão corrente da bipartição em racional e não racional, sendo que esta última incluiria os chamados desejos não racionais: o apetite e o impulso. Sobre este ponto, ver a nota de Zingano (2008) 1102a27-28.

77 Sobre este ponto, ver Aspásio (2006, p. 32-37).

78 Como disse Burnyeat (2010, p. 156): "Aristóteles conheceu o intelectualismo sob a forma da dou- 
Em suma, ao político cabe compreender que as disposições são constituídas pelo hábito e que são elas que põem os fins, e não a razão (logos) ou o intelecto (noûs) de modo direto, puro, imediato. Por isso, não é por determinação racional, como as ordens e sermões, ensino ou aquisição do conhecimento do que é correto a ser feito, mas por meio dos bons hábitos que o desejo pode vir a ser concorde com a razão. Ou seja, é preciso que o conhecimento do bem venha a ser objeto de meu prazer e de meu desejo, e passe a compor a minha segunda natureza. Como bem disse Burnyeat:

Pode me ser dito, e posso acreditar, que tais e tais ações são justas e nobres, mas não aprendi por mim mesmo (não guardei em meu coração, não fiz disso minha segunda natureza) que elas têm esse valor intrínseco até ter aprendido a valorizá-la (amá-las) por isso, com a consequência de que terei prazer em as praticar. A fim de entender e apreciar o valor que as torna em si mesmas prazerosas, tenho de aprender por mim mesmo a nelas ter prazer, o que exige tempo e prática - em uma palavra, habituação. ${ }^{79}$

Como vimos na passagem da EN III 5: 1114b23-25, são as disposições morais que põem os fins e a disposições são constituídas por ações das quais somos inteiramente causa, por isso, devemos dizer que somos apenas causa parcial ou coadjuvantes (sunaitia) das disposições e, consequentemente, do fim. Em outros termos, somos completa e diretamente senhores das ações e parcial e indiretamente senhores dos desejos oriundos das disposições. Com efeito, dizer que nossos desejos estão parcialmente sob nosso poder não significa dizer que o modo como o fim nos aparece nos seja absolutamente alheio, como se a aparição do fim fosse fruto de um fenômeno puramente natural.

Por um lado, contrariamente à posição naturalista, que assume a autonomia completa do desejo e a naturalização do fim, e, por outro, contrariamente à intelectualista, que assume a autonomia absoluta da razão e a constituição deliberativa do fim, Aristóteles se coloca numa posição intermediária ao pressupor que a determinação do desejo está parcialmente sob o nosso poder. Para que esta inferência fique ainda mais clara, vejamos a seguinte passagem:

trina socrática de que a virtude é conhecimento. Ele reage enfatizando a importância dos começos e do desenvolvimento gradual de bons hábitos de sentimento".

79 BURNYEAT, 2010, p. 167. 
As ações e as disposições não são voluntárias do mesmo modo; com efeito, de um lado, somos senhores (kupioi) de nossas ações do início ao fim, desde que conhecedores das circunstâncias; de outro, somos senhores do início das disposições, mas o acréscimo caso a caso não é distinguível, assim como ocorre nas doenças. Porque, porém, está em nosso poder nos comportarmos assim ou não assim, por esta razão são voluntárias (EN III 5: 1114b30-1115a3). ${ }^{80}$

Como foi dito na referida passagem, as ações são mais voluntárias que as disposições, uma vez que somos mais senhores dessas do que daquelas. Basta defender esta tese para negarmos uma concepção naturalista ou racionalista da constituição do fim. Aristóteles concebe que somos causa de nossa disposição inicialmente, pois agimos regularmente de certo modo e não de modo contrário, e assim adquirimos certa disposição ou tendência para agir e para desejar de certo modo (por exemplo, de modo justo e não injusto). Assim, podemos inferir que somos em parte senhores de certas regularidades de desejos, pois desejamos comumente aquilo com o qual nos habituamos a desejar.

De qualquer maneira, mesmo já tendo adquirido certo hábito, ainda podemos escolher se continuamos ou não a agir e a desejar de certo modo. O que não podemos escolher é se desejamos isto aqui (este objeto particular) no ato mesmo de desejar, ainda que tenhamos todo o poder para decidir realizar ou não isto aqui que estamos desejando. Resumidamente, não podemos escolher o que desejar no ato mesmo de desejar, mas podemos escolher mudar certos modos de desejar, o que significa mudar nosso modo de ser, nossa segunda natureza, nosso caráter. A princípio, sempre teremos a possibilidade de refrear certos desejos, de interromper o fluxo contínuo de desejos em uma certa direção. Para tanto, é preciso se controlar e agir como ordena a reta razão, contrariando certo modo de desejar, certa regularidade e repetições de desejos e ações, como tipicamente faz o controlado (encratês). Este não age segundo a razão porque não mais deseja o que é contrário a ela, porém, diante do conflito entre dois desejos, um segundo a razão e outro contrário a ela, vence o primeiro. ${ }^{81}$ Já no caso do 
descontrolado (acrático) vence o desejo contrário à razão (epithumia ou thumos) sobre aquele que é segundo a razão (boulêsis). ${ }^{82}$

Em suma, quando há conflito moral, temos tanto um fim desejado conforme a reta razão como outro contrário a ela. Por isso, quando Aristóteles diz que há conflito entre escolha deliberada e apetite, mas não entre apetites, devemos entender que há conflito entre querer certo fim (enquanto um desejo conforme a reta razão, portanto, conforme a própria escolha deliberada por ter sido aprovado por ela) e ter apetite por outro fim (enquanto um desejo contrário à reta razão, portanto, contrário à própria escolha deliberada). ${ }^{83}$ Para que haja harmonia e o conflito cesse, o apetite e o impulso devem estar suficientemente habituados a ouvir a razão, de modo que o desejo em geral (orexis), o que inclui os três tipos, esteja habituado a desejar conformemente à reta razão. Em suma, para entender o conflito moral não há necessidade de supor a existência de um desejo próprio da parte racional, basta supor a existência de um desejo conforme e outro contrário à parte racional. Por isso, mesmo que o conflito seja sempre um conflito de desejos, daí não se autoriza inferir que um seja próprio da parte racional; basta que ele seja o mais obediente a ela.

Por fim, vimos que é por meio do hábito que a razão penetra no desejo educando-o, persuadindo-o com mais intensidade e facilidade, afinal o hábito

$82 \mathrm{Na}$ análise da justiça, livro $\mathrm{V}$, capítulo 9, Aristóteles diz que não é possível agir injustamente contra si mesmo, ainda que seja possível agir voluntariamente contra o querer, como ocorre no caso do acrático. Sem especificar o que isso significa no contexto referido, vale destacar a afirmação ipsis litteris de que o acrático "age contrariamente ao querer (para ten boulesin prattei), já que ninguém quer algo que não pensa ser bom, mas o acrático faz o que ele pensa que não deve fazer" (1136b7-9).

83 Que o apetite não é contrário ao apetite, ver EN III 2: 1111b15-16. Que o descontrolado age por apetite e não conforme a escolha deliberada, ver 1111b13-14, embora faça a escolha correta (1151b6-7). Contrariamente à interpretação de Irwin (1992, p. 460), a qual justifica e endossa a concepção aquiniana de que a boulêsis é um desejo da parte racional, isto é, voluntas, a escolha não é um desejo sustentado pela boulêsis, pois é possível haver escolha a partir de todos os tipos de desejo. Por isso, ela é antes a desejada decisão em realizar os meios com vistas a um fim. O conflito moral próprio do acrático e do encratês se traduz por um conflito de impulsos (hormai: 1102b21), mas não de um impulso vindo da parte irracional, da epithumia ou do thumos, e outro vindo da parte racional, a boulêsis; o que facultaria à parte racional a capacidade de desejar, como interpreta Irwin (1992, p. 459). Há um conflito de impulsos que se traduz por um conflito de desejos, um conforme a razão, a boulêsis, e outro contrário à razão, a epithumia ou o thumos. Sendo assim, se, no acrático, vence o apetite, então é porque o apetite é mais forte do que o querer; já com o encratês se passa o contrário, é o querer que vence o apetite. 
prepara o desejo para ouvir a razão e segui-la. Vejamos agora o papel do autoconhecimento para a educação dos desejos.

\section{O conhecimento de si}

Uma das coisas mais difíceis é ter controle sobre a própria mente e uma das coisas mais perigosas é não ter controle sobre ela. Nada mais explica tão bem a razão pela qual o governo de si mesmo é o principal mote da ética antiga, mote este que, em verdade, não deixa de ser absolutamente atual e sempre. O governo de si implica conhecimento e cuidado de si. Embora esses dois temas não tenham o mesmo peso e desenvolvimento na ética aristotélica como na platônica, segue abaixo algumas linhas sobre o que Aristóteles compreendia por conhecimento de si e sua importância para a educação moral.

Como foi dito, há um segundo modo pelo qual a razão pode atuar sobre o desejo além daquele que é próprio do processo formativo do caráter. Este segundo modo se caracteriza pela possibilidade de o adulto mudar as disposições já adquiridas, ou seja, de aperfeiçoar o seu caráter através da mudança de hábito, o que implica ter conhecimento de si. Para tanto, é fundamental que ele saiba para quais desejos ele tende, quais hábitos engendram tais desejos e como é possível efetivamente mudar de hábito.

Assim sendo, este segundo modo de atuação da razão, que parece ser primordialmente avaliativo e controlador, se expressa pelo que chamamos de conhecimento de si e cura pelo contrário. Nas breves palavras do filósofo dedicadas a esta questão, temos o que se segue:

Devemos ficar atentos aos erros aos quais somos mais propensos: alguns tendem para uns; outros, para outros. Isto torna-se conhecido pelo prazer e pela dor por que passamos. Devemos puxar a nós mesmos em direção ao ponto oposto, pois chegaremos ao meio termo afastando-nos tanto quanto possível do erro, como fazem os que endireitam a madeira empenada (EN II 9: 1109b2-8).

Visto que a virtude moral é um meio termo nas emoções e nas ações, conhecer a si mesmo nada mais é do que conhecer se as disposições são excessivas ou estão em falta, portanto, se sentimos emoções e agimos de modo excessivo ou em falta. Conhecendo primeiramente nossas tendências ou propensões, podemos realizar o que ficou conhecido na exegese por "cura pelo contrário". 
O autoconhecimento não serve senão para que possamos mudar de hábito de modo a nos direcionarmos para a mediania e adquirirmos a disposição mediana, isto é, virtuosa. Em suma, toda cura pelo contrário implica conhecimento de si.

Há outras passagens em que Aristóteles acentua a necessidade do conhecimento de si para não cairmos em falta ou em excesso. Por exemplo, quanto à virtude da grandeza de espírito (megalopsuchia), o conhecimento de si é importante para não nos tornarmos alguém de baixa autoestima, de alma pequena (mikropsuchos), tampouco nos estimarmos em excesso e nos tornarmos presunçosos e ignorantes de nós mesmo. ${ }^{84}$ Outro exemplo é o do esbanjador, pois Aristóteles nos diz que aquele que erra por excesso de generosidade pode se autoconhecer e se curar ao agir contrariamente ao seu hábito, já o avaro é incurável. ${ }^{85}$ Da mesma maneira, sabemos que o controlado ou o descontrolado são curáveis, já o intemperante não.

O conhecimento de si significa ter consciência sobre as próprias disposições e de que as disposições provêm do exercitar-se nos atos particulares, o que implica saber a quais desejos tendemos mais. Conhecer a regularidade dos desejos não é senão se dar conta da repetição de nossas ações. Uma vez tendo consciência desta tendência, deve-se procurar mudar, agindo no sentido contrário até encontrar o meio termo nas ações, assim como nas emoções e desejos. Tendo tais cuidados consigo mesmo, mais se é capaz de atingir o meio termo quanto ao prazer e à dor no que concerne às emoções e às ações, portanto, mais se é capaz de governar a si mesmo.

Por isso, a educação do desejo daquele que ainda pode mudar de caráter implica autoconhecimento. Conhecer seus desejos, avaliá-los, corrigi-los, controlá-los quando preciso, parecem ser funções próprias de nossa racionalidade. Como diz o filósofo, uma vez tendo conhecimento de suas tendências, não basta querer mudar, ${ }^{86}$ deve-se agir para tanto, ou seja, deve-se cultivar bons há-

84 Cf. EN IV 3: 1125a20-33. Ver capítulo seguinte, seção "A grandeza de espírito".

85 Cf. EN IV 1: 1121a20 e 1121b11-14. Ver capítulo seguinte, seção "A generosidade”.

86 "O ignorar que as disposições provêm do exercitar-se nos atos particulares é a marca de alguém totalmente insensível; mais ainda, é irracional que o homem que comete uma injustiça não pretenda ser injusto ou que o homem que cai na intemperança não pretenda ser intemperante; se alguém pratica as ações pelas quais se tornará injusto, não ignorando, ele é voluntariamente injusto. Todavia, isto não significa que, sendo injusto, cessará de o ser quando quiser (boulêtai) e ficará justo; tampouco o doente cessa de estar doente e fica são quando quer" (EN III 5: 1114a13-15). 
bitos de modo a educar o desejo para o meio termo. Ou seja, não basta querer (boulêsis) mudar para se mudar de fato; assim como não basta ao doente simplesmente querer se curar e não fazer nada para tanto. A percepção de si e a ação parecem ser as principais vias de acesso da razão ao desejo. Olhar para os próprios desejos e agir para transformá-los dando a si mesmo as boas razões para tanto são as condições necessárias para que a persuasão e a mudança efetivamente ocorram. Afinal, ninguém muda se não estiver convencido de que é preciso mudar e assim agir para que a mudança se efetive. O processo certamente é gradual e árduo.

Podemos concluir que não basta querer a mudança para mudar de fato, pois é preciso educar o desejo a desejar as atividades que conduzem a esta mudança, o que pressupõe começar a agir no sentido contrário ao que se costuma agir. Somente assim será possível passar a desejar no sentido contrário ao que se costuma desejar. Isso porque, o querer, tendo como objeto o que julgamos ser um bem, não é capaz de vencer o desejo pelo prazeroso (epithumia) ou o impulso de aversão ao doloroso (thumos). É preciso incutir o hábito de se desejar bem, incluindo aí os três tipos de desejo, mas, sobretudo, aqueles que são mais avessos à razão: o impulso e, ainda mais, o apetite.$^{87}$ Não basta, portanto, querer apenas o que é bom. É preciso que isso também apareça como prazeroso, isto é, como objeto do apetite. Menos ainda basta saber que é bom para desejá-lo, como queria Sócrates. ${ }^{88}$ É preciso que o bem não seja apenas um objeto cognitivo, mas que se torne objeto de nosso desejo e parte de nossa segunda natureza. Enfim, para mudar é preciso conhecer a si mesmo, desejar mudar e praticar ações contrárias ao que se estava habituado. Portanto, ser diferente do que se é significa mudar de hábito.

Até o momento, vimos como a educação é possível, isto é, que a razão pode atuar sobre o desejo persuadindo-o, e como ela se realiza por meio do hábito e do autoconhecimento. Vejamos, agora, o que é exatamente um desejo educado a partir de uma espécie de escrutínio da alma do virtuoso em contraste com as demais figuras morais.

87 Esta questão será tratada com mais detalhe na seção "Querer, apetite e impulso". 


\section{O desejo virtuoso ${ }^{89}$}

O desejo, ninguém sabe ao certo o que é, muito menos o que fazer com ele. Mas continuamos, desde a época dos gregos ou mesmo antes, nos esforçando para apreender algo de sua natureza, algum aspecto que seja; e, mais ainda, insistimos em vislumbrar o seu papel nas ações que nos conduzem ao bem-estar moral e psicológico, portanto, à felicidade.

Para Aristóteles, de modo geral, a felicidade ou o bem viver (eudaimonia) depende necessariamente do nosso modo de ser e agir no mundo. Em outras palavras, viver bem significa agir bem, portanto, ser uma pessoa boa ou virtuosa (spoudaios). Na ética aristotélica, a tripla imbricação entre viver bem, agir bem e ser uma pessoa boa se expressa na definição de seu principal objeto, a saber: a eudaimonia é uma "atividade da alma segundo perfeita virtude" (EN I 13: 1102a5-6). Ou seja, viver bem é realizar atividades virtuosas e, para realizá-las de modo virtuoso, é preciso ser uma pessoa virtuosa. Não é possível viver bem sem agir bem, tampouco seria possível agir virtuosamente sem ser uma pessoa virtuosa, ou seja, sem ter a disposição virtuosa (hexis aretê) e, de fato, praticar ações virtuosas. A disposição virtuosa, por sua vez, é adquirida e mantida pelo hábito de se agir virtuosamente. É preciso praticar com regularidade ações virtuosas para se tornar alguém virtuoso, o que significa, sem dúvida, educar o desejo (orexis). ${ }^{90}$ Isso significa, como vimos, que o desejo tem um papel central em uma concepção ética que se fundamenta nas virtudes e nas ações, como é o caso da ética aristotélica. O objetivo deste texto, portanto, é esclarecer o que significa educar o desejo de modo que ele se torne um desejo virtuoso.

A educação do desejo é justamente o que Aristóteles denomina por aquisição da disposição virtuosa. Em outras palavras, ter adquirido a virtude pressupõe ter educado o desejo a desejar o bem em vista dele mesmo. Desta expressão - "desejar o bem em vista dele mesmo", devemos, primeiramente, compreender o que significa desejar algo em vista dele mesmo. Desejamos algo em vista dele mesmo quando tomamos certo objeto como um fim em si mesmo de modo que a ação tenha como finalidade apenas a sua própria realização. Ora, sabemos

89 Uma primeira versão deste texto foi publicada com o título $O$ desejo virtuoso segundo Aristóteles. In: CARVALHO, M.; FIGUEIREDO, V. (Org.). Filosofia antiga e medieval. 1. ed. São Paulo: Anpof, 2013. p. 295-303.

90 “Adquirimos as virtudes tendo-as primeiramente exercitado (

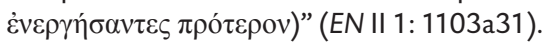


que o bem pode ser desejado como um fim em vista dele mesmo ou como um meio para outro fim. Isso significa que um bem pode ser perseguido (diôkton) ou buscado (hairesin) (i) como um fim em vista dele mesmo (kath'hauto), (ii) como meio para outro fim, (iii) como um fim em vista dele mesmo e também como um meio para outro fim (kath'hauta kai dia toûth' haireton). ${ }^{91}$ Vejamos como Aristóteles aplica essas três formas de desejar para os bens éticos ou bens práticos.

Segundo o filósofo, o bem prático (prakton agathon) é o fim de toda e qualquer ação e a felicidade, por ser o fim último de nossas ações, é o bem supremo (ariston). ${ }^{92}$ Enquanto o bem supremo é desejado exclusivamente em vista dele mesmo, os outros bens, como o prazer, a riqueza, a honra, a vitória, a inteligência, a saúde e assim por diante são desejados em vista deles mesmos e como meios para a realização da felicidade. Por isso, quando nos referirmos a este tipo de desejo pelo bem como fim em si mesmo, estamos nos referindo tanto ao bem supremo como aos bens que são a própria realização do bem supremo. Este tipo de desejo tem como objeto não um meio exclusivamente, mas um fim tomado em si mesmo, exatamente como deve ser desejada a ação virtuosa.

Aristóteles, como vimos, insiste claramente em distinguir escolha (prohairesis) e os três tipos de desejo (orexis): impulso (thumos), apetite (epithumia) e querer (boulêsis). Brevemente, toda escolha diz respeito a um meio, enquanto o objeto de desejo é um fim a partir do qual deliberamos sobre os meios. ${ }^{93}$ Deliberamos e escolhemos os meios, mas não os fins. Os meios escolhidos deliberadamente são também objeto de desejo, mas de um desejo pelo meio e não pelo fim. Este desejo pelo meio, isto é, este desejo deliberado (orexis bouleutikê) é o que o filósofo denominou de escolha. Com efeito, se desejamos certo meio para realizar um fim, assim o desejamos não em vista dele mesmo, mas com vistas ao fim já dado. Por isso, Aristóteles define brevemente a escolha como "desejo

91 Tomo as palavras perseguido (diôkton) ou buscado (hairesin) como sinônimos de desejado (ver EN I 7: 1097a23-b6). Entendo hairesin como objeto de busca, embora seja comumente traduzido por objeto de escolha, pois os animais não escolhem, embora busquem algo na medida em que o desejam. Portanto, hairesin, neste sentido, é o mesmo que perseguir ou buscar o objeto desejado e não uma operação racional de eleição de um objeto antes que outros. Como razão suplementar, ver Zingano (2008, nota 1104b30-31).

92 VerENI 7: 1097b1-6.

93 Como diz Aristóteles: "Deliberamos não sobre os fins, mas sobre as coisas que conduzem aos fins (bouleuometha d' ou peri tôn telôn, alla peri tôn pros ta telê)" (EN III 3: 1112b12). 
deliberado do que está em nosso poder (bouleutikê orexis tôn eph'hêmîn)" (EN III 3: 1113a11), ${ }^{94}$ ou seja, um desejo que se constituiu após e conforme a deliberação de realizar um meio com vista a um fim que esteja em nosso poder realizar. Já o desejo que tem como objeto um fim se manifesta de três modos: o desejo pelo enfrentamento da dor (thumos), o desejo pelo prazeroso (epithumia) e o desejo pelo bem ou pelo fim (boulêsis).

Em resumo, a distinção é clara entre dois tipos de desejo: o desejo pelo fim e o desejo pelo meio. O primeiro não é constituído por deliberação, enquanto o segundo é resultante da deliberação. Por isso, quando dizemos que desejamos algo, é preciso distinguir se o desejamos como um fim ou como um meio. Todas as ações que são a própria realização da felicidade, quando desejadas corretamente, são desejadas como fins e não meios escolhidos em vista de outro fim, pois que outro fim haveria de existir para além do fim último, do bem supremo, da felicidade? Sendo assim, é mais adequado dizer, segundo o filósofo, que "nós queremos (boulometha) estar saudáveis, mas escolhemos deliberadamente (proairoumetha) que coisas nos tornarão saudáveis; queremos ser felizes e o declaramos, mas não é apropriado dizer que escolhemos deliberadamente ser felizes” (EN III 2: 1111b27-29). Ser saudável é uma realização da felicidade, portanto, desejar ser saudável é desejar ser feliz, e não desejamos ser felizes como meio para outro fim. A felicidade é o fim último, portanto, a razão última de todas as nossas ações.

Tendo em mente esta distinção entre esses dois modos de operar do desejo, podemos compreender o seguinte preceito da ética aristotélica: nós devemos escolher e, portanto, desejar os meios que nos permitem realizar adequadamente a ação virtuosa, mas a ação virtuosa, que é, por sua vez, a própria realização da felicidade, não deveria ser escolhida nem desejada como um meio para a realização de outro fim que não ela mesma. A ação virtuosa deve ser desejada como um fim, ou seja, como um bem em vista dele mesmo. Portanto, o virtuoso age virtuosamente porque ele quer agir assim; porque, em verdade, ele quer ser feliz, como todos nós, mas, diferentemente da maioria de nós, ele sabe como ser feliz.

94 A frase em que se encontra tal definição é a conclusão de $E N$ III 3, capítulo em que se define deliberação: "Dado que o objeto de escolha deliberada é o objeto de desejo do que está em seu poder após a deliberação, a escolha deliberada será, então, o desejo deliberado do que está em nosso poder, pois, julgando em função de ter deliberado, desejamos conformemente à deliberação" (1113a9-12). Também em VI 2: 1139b4-5, a escolha é definida como um intelecto desejante (orektikos nous) ou um desejo pensante (orexis dianoêtikê). 
Ele quer agir bem e ser uma pessoa boa porque ele quer viver bem. A excelência ética do desejo, portanto, se expressa no modo de ser, agir e viver do virtuoso.

Como disse acima, a aquisição da virtude pressupõe a educação do desejo para que ele passe a ter como objeto a ação virtuosa em vista dela mesma, pois a disposição virtuosa é essencialmente uma disposição de bem agir e agir bem implica desejar e deliberadamente escolher realizar boas ações. O virtuoso é justamente aquele que se dispõe a agir virtuosamente por desejar realizar ações virtuosas em vista delas mesmas. Isso pressupõe, do ponto de vista ético, desejar corretamente ou, como diz Aristóteles, ter desejos retos (orthê).${ }^{95} \mathrm{Um}$ desejo é reto quando tem como objeto exclusivamente a ação virtuosa, portanto, quando a finalidade da ação virtuosa é a sua própria realização. Isso significa que a ética aristotélica se fundamenta na possibilidade, ou melhor, na necessidade de o desejo ser educado a tomar como objeto o bem em vista dele mesmo e assim se tornar virtuoso.

Sendo assim, antes de perguntar como podemos desejar retamente, temos que perguntar se é possível desejar desse modo? Como já vimos, essa possiblidade se justifica, segundo o Estagirita, pela própria concepção de natureza humana, pois a parte desiderativa da alma é, por natureza, capaz de ouvir e obedecer à parte racional. A razão, por sua vez, é capaz de distinguir contrários e assim determinar o que é verdadeiro e falso, o que é correto e incorreto, enfim, o que é bom e ruim. Já o desejo é a capacidade de nos mover na medida em que ele é uma atividade (energeia) de nossa alma que se realiza no corpo movendo-o em direção ao que lhe falta: o objeto desejado. ${ }^{96}$ Mesmo sendo uma atividade da parte não racional (alogon) da alma, ela pode ser orientada pela razão, isto é, ela pode seguir o que a razão determina como sendo bom. ${ }^{97}$ Se não houvesse essa possiblidade de habituar o desejo a tomar

95 "Como a virtude ética é uma disposição de escolher por deliberação (hexis phroairetikê) e a escoIha deliberada é um desejo deliberado (orexis bouleutikê), então tanto a razão deve ser verdadeira como o desejo reto, se a escolha é boa, e o último deve perseguir o que assere a razão" (EN VI 2: 1139a22-27).

96 Depois de dizer que o movimento implica três coisas: aquilo que move, aquilo que move e é movido e aquilo que é movido, Aristóteles define o desejo da seguinte maneira: "Aquilo que move sem ser movido é o bem prático, aquilo que move e é movido é a faculdade desiderativa (to orektikon) (pois aquilo que é movido assim o é na medida em que deseja, e o desejo (orexis) é um movimento (kinêsis) ou atividade (energeia)), e aquilo que é movido é o animal” (DA III 10: 433b15-18).

97 Ver EN VI 2: 1139a27. 
como objeto o bem concebido racionalmente, não poderíamos falar em aquisição de virtude, nem em autonomia do indivíduo para desejar e escolher deliberadamente as próprias ações conforme lhe mostra a sua razão. Teríamos que conceber ações corretas como pura e simplesmente obediência às leis e às regras morais. Ao contrário desta moral hobbesiana, Aristóteles pressupõe que o indivíduo seja capaz de autonomamente decidir o que é melhor em cada situação particular e agir em função disto que fora decidido porque assim deseja agir e não porque esteja coagido a obedecer a uma regra, lei ou a qualquer outra imposição alheia.

Pois bem, é preciso esclarecer que não é apenas possível, mas também necessário desejar o bem em vista dele mesmo para que a ação seja propriamente virtuosa, ou seja, para que a ação seja realizada de modo virtuoso. Nas palavras de Aristóteles: "os atos são ditos justos e temperantes quando são tais quais os que fariam o justo ou o temperante: é justo e temperante não quem os realiza, mas quem os realiza também tal como os justos e temperantes os realizam" (EN II 3: 1105b5-10). Ou seja, para que uma ação realizada possa ser considerada propriamente virtuosa ela deve ter sido realizada de modo virtuoso, portanto, tendo sido desejada e realizada como um fim em si mesmo. Ora, segundo o filósofo estagirita, é possível voluntariamente agir bem simplesmente para agradar outrem ou para não ser punido. Alguém poderia, por exemplo, elogiar um político para obter favores, sem de fato querer elogiá-lo, sem achar que os elogios são merecidos. Um jovem poderia, por exemplo, ajudar um idoso a atravessar a rua, sem querer realmente ajudá-lo, mas para roubá-lo no decorrer do percurso. Isso significa que uma ação virtuosa pode ser voluntariamente realizada como meio para outro fim, e, se assim o for, não poderíamos dizer que ela fora realizada de modo virtuoso.

Do que foi dito, podemos concluir que a diferença essencial entre alguém que já se tornou virtuoso e alguém que ainda não se tornou, é que o último faz algo bom como um meio para outro fim, enquanto que o primeiro, o virtuoso, age desejando a boa ação por ela mesma. Por isso, o virtuoso não possui outro desejo senão o de realizar esta boa ação em particular. Ao contrário do virtuoso, aquele que ainda não adquiriu a virtude faz o bem porque quer obter algo com esta ação, mesmo que seja o prazer de ter agido bem. Em suma, a diferença entre aquele que ainda não é e aquele que já é virtuoso reside justamente na disposição de caráter de cada um, portanto, no modo de pensar, desejar e agir de cada um. Por isso, o modo como desejamos realizar uma ação virtuosa sinaliza o tipo de 
caráter que temos, a depender se a desejamos como um fim ou como um meio em vista de outro fim.

Como vimos, segundo Aristóteles, é possível desejar algo bom não em vista dele mesmo, mas para obter certo prazer ou evitar certa dor subsequente, como um guerreiro que guerreia pelo prazer de obter honras ou pelo medo de ser punido por fugir da batalha. O fim desejado por este "pseudo" guerreiro não é o próprio bem, isto é, vencer a batalha para defender a cidade, mas vencer para ser afamado, glorificado, ou, ao menos, para não ser punido e ver sua reputação arruinada. O guerreiro verdadeiramente corajoso, porém, vai à batalha por ser belo (kalos) agir corajosamente. Teucro, exímio guerreiro grego, ilustra exatamente esta tese aristotélica. Em um episódio da Ilíada, Agamenon, rei dos aqueus, vendo o arqueiro Teucro dizimar os troianos, aproxima-se dele e diz:

'Ó capitão de exércitos, ó Telamônio, segue atirando; sê, para os Aqueus, farol; e para Telamon, teu pai, que te educou, desde criança, acolhendo-te em sua casa, embora filho bastardo. Eu te prometo: se Zeus porta-escudo e Atena me concedem que devaste a bem-construída cidadela de Ílion, o primeiro de todos, após mim, hás de ser na partilha dos prêmios: uma trípode, uma biga bem-equipada e corcéis, ou a mulher que escolhas para a cama'. Em resposta, lhe diz Teucro, imáculo: 'Para que incitar-me, Atreide, gloriosíssimo, se, por meu próprio impulso (thumos), eu já me esforço ao máximo?' (Ilíada, VIII, vv. 283-296). ${ }^{98}$

Como vimos na citação acima, Teucro é movido apenas pelo seu impulso de guerrear, de ser corajoso e isso faz dele um verdadeiro guerreiro. Se, então, o corajoso deseja simplesmente agir com coragem, ele certamente deseja a ação corajosa por ela mesma e um sinal disso é o prazer que ele sente ao agir assim. Segundo Aristóteles, o prazer que sente o virtuoso ao realizar uma ação virtuosa é qualitativamente superior ao daquele que a realizou apenas como meio para um fim não exatamente virtuoso. ${ }^{99}$

98 Tradução de Haroldo de Campos (2003).

99 Desse modo, segundo Aristóteles, “deve-se tomar os prazeres e as dores nas ações como sendo sinais (semêion) das disposições: quem se abstém dos prazeres corporais e se deleita (chairôn) com isso é temperante; ao passo que quem se incomoda com isso é intemperante; quem suporta as coisas temíveis e se deleita, ou ao menos não sofre, é corajoso; ao passo que quem sofre é covarde" (EN II 3:1104b3-8). Ver a seção “Problema II: Prazer e virtude”, do capítulo segundo da primeira parte deste livro. 
Assim, desejar o bem em vista dele mesmo também significa ter prazer em realizá-lo. Como não nascemos desejando ser corajosos, o desejo, neste caso específico o impulso (thumos), deve se habituar a enfrentar certas dores e, segundo o Estagirita, nada melhor do que o hábito em agir corajosamente para tornar alguém corajoso. Afinal, o hábito (ethos) faz parecer familiar àquilo que antes era estranho e faz parecer prazeroso o que antes era doloroso. ${ }^{100}$ Certamente, não nos é naturalmente dado o impulso de colocar a nossa própria vida em risco em uma guerra. Este desejo é socialmente cultivado no bom guerreiro. A boa disposição, como a disposição corajosa, é incutida por repetidas ações; no caso, ações corajosas.

Se o que foi dito está correto, então antes de nos tornarmos virtuosos, realizamos ações virtuosas não de modo virtuoso, pois ainda não as desejamos por elas mesmas, mas por outra motivação, como obedecer a uma autoridade externa em vista de ser elogiado ou de evitar ser repreendido. Com a prática constante, tanto nos tornamos mais capazes de apreender corretamente o bem a ser feito, como nos habituamos a ter prazer com o bem em vista dele mesmo e não pela consequência prazerosa da realização da boa ação. Resumidamente, ser educado é passar a se habituar a desejar o que se deve e como se deve. Ou seja, o desejo precisa se habituar a ter como objeto o que se deve - a ação virtuosa - até que o modo de desejar também se torne virtuoso, isto é, que a ação virtuosa seja desejada em vista dela mesma.

Sendo assim, podemos concluir que o virtuoso não apenas deve desejar o bem, mas deve desejá-lo em vista dele mesmo. Este modo virtuoso de desejar certamente distingue o desejo do virtuoso daquele do homem controlado (encratês), que tem governo de si e possui a disposição moral mais próxima da virtude, embora ainda não a tenha plenamente. ${ }^{101} \mathrm{O}$ controlado também deseja o bem, mas não em vista dele mesmo. Ao agir, ele está sendo movido pelo que podemos chamar de desejo de superação de si. Ele se esforça por vencer a força propulsora do apetite (epithumia) que o leva para o sentido contrário do que ele

100 Nas palavras do filósofo: "o familiar e o habitual estão entre as coisas prazerosas, pois muitas coisas não são naturalmente prazerosas, mas o hábito as torna prazerosas” (Ret. I 10: 1369b18).

101 Embora o controle e o descontrole não sejam, respectivamente, nem virtude (aretê) nem vício (mochthêria), ainda assim eles compartilham do mesmo gênero, ou seja, eles são disposições (hexeis) (cf. EN VII 1: 1145b1-3). Durante todo o Tratado da Acrasia (VII 1-10), o filósofo fornece as semelhanças e diferenças entre, por um lado, controle e temperança e, por outro, descontrole e intemperança. 
julga ser bom. A ação contrária ao apetite, que ele julga ser boa, mas não prazerosa, não precisaria ser também ela objeto de seu desejo e, portanto, fruto de algum prazer? Ora, por que ele agiria contrariamente ao seu apetite se ele não desejasse e não tivesse nenhum prazer em agir assim?

Para responder a esta pergunta, devemos considerar que o que lhe move a agir conforme o que ele julga ser bom e contrariamente ao que se lhe apresenta como prazeroso é o querer ou o chamado "desejo racional” (boulêsis) pelo bem. O controlado age por ter sido convencido pela razão e quem age conforme a razão age querendo, pois, como diz Aristóteles, "quando alguém é movido de acordo com o raciocínio (kata ton logismon), ele também é movido de acordo com o querer (kata boulêsin)" (DA III 10: 433a24-25). ${ }^{102}$ Assim, não poderíamos dizer que ele foi forçado a agir bem. Ao contrário, ele foi persuadido por sua própria razão de modo a agir voluntariamente ou de bom grado. Como sabemos, a razão e não o desejo é capaz de persuadir e, mais do que isso, na verdade, a persuasão é o modo pelo qual a razão educa o desejo e orienta nossas ações, como veremos melhor adiante. Ou seja, não se trata apenas de habituar-se a agir bem, é preciso dizer que este hábito cultiva o desejo a ser persuadido pela razão e que a razão exerce, para além da deliberação, duas outras funções práticas essenciais: apreender o bem e persuadir o desejo a desejar o bem em vista dele mesmo. Nas palavras do filósofo: "a persuasão (peitô) é oposta à força (biai) e à necessidade (anankêi), e o controlado, conduzido ao que foi persuadido, procede não por força, mas voluntariamente; enquanto o apetite não conduz alguém por tê-lo persuadido, pois não participa da razão" (EE II, 8, 1224b1-3). A explicação para o ato controlado ser voluntário é que o princípio da ação estava no agente no sentido forte do termo, ou seja, estava no poder do agente tanto agir como não agir. O motivo da ação é interno (esôthen) e não externo (exôthen) ao agente. O controlado se mantém firme diante da afecção (pathos) e do apetite por ter sido bem persuadido pela razão. ${ }^{103}$

Mas será que ele quer o bem em vista dele mesmo, tal como o virtuoso? Certamente não, caso contrário ele não teria que controlar os seus apetites, pois teria apenas desejos retos. O controlado deseja em alguma medida o bem, mas não em vista dele mesmo e sim em vista do prazer subsequente. Ou seja, ele age bem porque deseja se controlar e se tornar virtuoso e não simplesmente (haplôs)

102 Cf. também DA III 11: 434a12-14 e EN VII 9: 1151b33-1152a5.

103 Cf. EN VII, 9, 1151b9-10. 
porque é virtuoso agir assim. Então, similarmente ao virtuoso, ele age conforme dita sua razão; porém, diferentemente do virtuoso, ele não age conforme a razão porque não mais deseja o que é contrário a ela; ele age assim apesar de ter apetites contrários. Diante do conflito entre dois desejos, um segundo a razão e outro contrário a ela, vence o primeiro. Já no caso do descontrolado (acrático) vence o desejo contrário à razão (epithumia ou thumos) sobre aquele que é segundo a razão (boulêsis). ${ }^{104}$

Desse modo, não poderíamos dizer que há apenas dor na ação controlada, tampouco haveria apenas prazer na ação descontrolada. A dor certamente está presente em ambos os casos, pois a situação de ter de se controlar ou de acabar se descontrolando é conflituosa por excelência. Estar em conflito já é por si só doloroso. Pois bem, além da dor do conflito, o controlado sente, por um lado, dor ao se controlar refreando o prazer que surgiria da realização de seu apetite, por outro lado, ele sente prazer por ter se controlado: o prazer do alívio de não ter que se arrepender depois, o prazer por ter se superado, enfim, o prazer por ter à sua espera o benefício de se tornar melhor do que se é ou mesmo de já ter se tornado melhor do que se é. Já o descontrolado sente, por um lado, o prazer de ter saciado o seu apetite, mas sente a dor que antecede à satisfação do prazer, a dor do conflito moral, da hesitação, e a dor que sucede à satisfação do prazer, a dor do arrependimento, da vergonha de si mesmo, do sentimento de fracasso e de impotência. Nas palavras do filósofo:

Ademais, tanto o prazer como a dor estão presentes em ambos os casos: pois alguém que está se controlando sofre no momento em que age contrariamente ao seu apetite e se deleita com o prazer antecipado de que se beneficiará posteriormente, ou mesmo de já estar se beneficiando por ser saudável: ${ }^{105}$ e o descontrolado deleita-se em estar conquistando, ao se descontrolar, o que the apetece, mas sofre com a dor antecipada, pois pensa que age mal (EE II, 8, 1224b16-21).

$104 \mathrm{Na}$ análise da justiça, livro V, capítulo 9, Aristóteles diz que não é possível agir injustamente contra si mesmo, ainda que seja possível agir voluntariamente contra o querer, como ocorre no caso do acrático. Sem especificar o que isso significa no contexto referido, vale destacar a afirmação ipsis litteris de que o acrático "age contrariamente ao querer (para ten boulêsin prattei), já que ninguém quer algo que não pensa ser bom, mas o acrático faz o que ele pensa que não deve fazer" (1136b7-9).

105 Deve-se levar em conta que ser saudável, do ponto de vista ético, é ser moralmente saudável (cf. EE VII, 2, 1235b36-1236a1). 
Assim, do mesmo modo em que dizemos que o "pseudo" corajoso age pelo prazer de ser honrado, podemos dizer que o controlado não é virtuoso ou é um "pseudo" virtuoso ao agir pelo prazer de se autocontrolar e assim se beneficiar, pois sua boa ação será reconhecida e ele mesmo se aproximará da virtude. Explico-me. Aos olhos de quem vê a ação boa sendo realizada pelo controlado, ela pode parecer propriamente virtuosa; mas se verificarmos o prazer que ele sente e os desejos que ele tem ao agir assim, constataremos que ele não é virtuoso, pois ele não deseja e sente prazer simplesmente por fazer o bem em vista dele mesmo, mas por superar a si mesmo e, quiçá, agradar aos outros. Agindo assim com certa frequência a sua razão pode ir persuadindo os seus apetites a terem prazer com o que se deve e como se deve. Desse modo, o controlado que se habitua a agir virtuosamente pode se tornar virtuoso. Disto podemos inferir que o controlado age corretamente conforme ordena sua razão, na medida em que ele quer, sobretudo, superar a si mesmo e assim o faz por almejar a virtude, a harmonia de seus desejos, o fim do conflito perturbador, que o arrasta para longe da virtude, para o desregramento e o aproxima tanto do descontrole (acrasia), como da intemperança (akolasia). Fica evidente, portanto, que o controlado sente prazer ao agir bem, mas não do mesmo modo que o virtuoso, pois a virtude consiste essencialmente na harmonia entre os desejos e não no controle de apetites desregrados.

$\mathrm{O}$ vicioso (kakos) também pode fazer algo bom, mas não porque ele quer se tornar virtuoso, como é o caso do controlado. Ele deseja certa ação boa (ajudar um idoso a atravessar a rua) unicamente em vista de um fim perverso (roubar o idoso). Ele sente prazer em realizar esta boa ação, mas não por realizá-la simplesmente e sim porque ela o aproxima do fim almejado. Neste caso, a boa ação é apenas um meio eficiente para um fim vil. Ela não poderia ser, em hipótese alguma, desejada em vista dela mesma pelo vicioso, nem em vista de qualquer superação de si ou aperfeiçoamento do caráter, como no caso do controlado. O vicioso não está em conflito como está aquele que se controla. Enquanto o vicioso sentiria o desprazer de não realizar a boa ação por não conseguir obter o seu fim perverso, o controlado sentiria o desprazer de ter sido vencido pelo seu apetite por ter se descontrolado e sentiria vergonha de ter sido fraco, de não ter tido governo sobre si mesmo, enfim, de ter se distanciado do caminho da virtude.

Por fim, podemos concluir este texto tendo ao menos a certeza de que desejar o bem em vista dele mesmo é o desejo propriamente virtuoso. Neste modo virtuoso de operar o desejo, prazer e desejo necessariamente coincidem. O objeto de ambos é o mesmo, qual seja: a ação virtuosa. Isso porque o virtuoso tanto 
deseja realizar o bem como tem prazer em realizá-lo. Assim, desejar o bem em vista dele mesmo implica necessariamente ter prazer em realizá-lo. Por isso, segundo Aristóteles, a educação do desejo tem como finalidade fazer com que prazer e desejo coincidam de modo que não haja conflito moral entre querer (boulêsis) o bem por um lado e ter apetite (epithumia) pelo prazer por outro, como acontece nos fenômenos de descontrole (acrasia) e de controle (encrateia). A finalidade última da educação ética é fazer com que o bem seja o único fim de nossas ações e desejos e que ele seja desejado em vista dele mesmo, isto é, por ser bom e não por ser simplesmente prazeroso.

Se, como vimos, o desejo deve ser educado para ouvir a razão de modo a se tornar virtuoso, isto é, a desejar o bem em vista dele mesmo, então resta-nos a tarefa de compreender mais profundamente a natureza de cada tipo de desejoo querer, o apetite e o impulso, bem como o modo pelo qual a razão é capaz de participar do desejo persuadindo-o.

\section{Querer, apetite e impulso}

\section{I}

Aristóteles possui, sem dúvida, uma teoria do desejo, embora não a tenha sistematizado e exposto ex professo em nenhuma de suas obras. A ausência de uma exposição mais sistemática não nos impede de recolher e analisar diversas passagens em que ele trata da diferenciação entre as três espécies de desejo (boulêsis, thumos e epithumia). Embora a definição de desejo tenha tido especial atenção do filósofo no De Anima, livro III, capítulo 10, o exame da natureza de cada tipo de desejo não encontrou um lugar assim privilegiado de exposição na obra do filósofo, o que torna a tarefa de obtê-la mais árdua. Não pretendo, todavia, encontrar a definição de cada espécie de desejo. Pretendo, tão somente e brevemente, analisar algumas passagens centrais das Éticas e do De Anima de Aristóteles de modo a expor a diferença específica de cada desejo. Afinal, se há três espécies de desejo segundo Aristóteles, como ele diferencia as espécies entre si? Quais são os critérios que ele utiliza para tanto? Estas são as perguntas que pretendo responder neste texto.

Aristóteles nos diz que o desejo (orexis) é um gênero que subsumi três espécies - querer (boulêsis), apetite (epithumia) e impulso (thumos). Todavia, não nos é evidente a diferença específica entre os tipos de desejos. Tendo em vista que o 
desejo é um movimento ou atividade da faculdade desiderativa que move o corpo do animal em direção ao objeto desejado (DA III, 10,433b13-20), faculdade esta não racional, embora seja capaz de dialogar com a razão (EN I, 13, 1103b29-a4), teremos mais clareza da diferença específica se nos detivermos tanto no tipo de objeto de cada espécie como na capacidade de diálogo que cada espécie tem com a razão. Isso porque são justamente estas duas características - objeto e participação racional - que nos fornecem a diferença específica entre os desejos.

\section{II}

Comecemos pelo critério da diferenciação pelo objeto. É bem sabido que o objeto do apetite é o prazer, ou melhor, uma atividade prazerosa. São diversas as passagens do corpus aristotelicum ${ }^{106}$ que atestam isso. Trata-se, certamente, de um desejo que compartilhamos com os animais, visto que o animal tem sensação de prazer e dor e isso já é suficiente para circunscrever em sua natureza o desejo pelo prazeroso ${ }^{107}$ : "os animais possuem ao menos um sentido: o tato. E, por haver percepção, há prazer e dor, bem como o prazeroso e o doloroso. Como há tais coisas, há também apetite, pois ele é o desejo pelo prazeroso" (DA II 3: 414a33-b6). No contexto da moral, portanto exclusivamente humano, ao distinguir escolha deliberada (prohairesis) de apetite em sua Ética Nicomaqueia, o filósofo diferencia o tipo de objeto de cada um e diz que "o apetite concerne ao prazer e à dor, já a escolha deliberada não” (EN III, 2, 1111b18). No tratado da temperança desta mesma obra, Aristóteles diz que há dois tipos de apetites: um comum a todos, pois nos é natural, e outro peculiar ou inusual (EN III, 11, 1118b9-25). O primeiro diz respeito a objetos necessários, como o apetite pela comida, já que todos necessitam de nutrientes sólidos e líquidos, e também o apetite sexual (eunês), já que todos necessitam de sexo, sobretudo os jovens. O apetite comum é natural e não diz respeito a um objeto prazeroso específico, mas simplesmente ao ato de comer, beber e fazer sexo. Afinal, "o apetite natural é apenas um preenchimento de uma carência” (1118b17-8). ${ }^{108}$ Já o apetite peculiar diz respeito a

106 Cf. Top. 140b27; PA 661a8; Ret. 1370a17 e 1369b15; EN III, 2, 1111b18; EE II, 6, 1223a35 e 1235b22. Ver também o comentário de Ross ( 1961, p. 222, nota 414b2).

107 Cf. também De Insomni, 454b24-33.

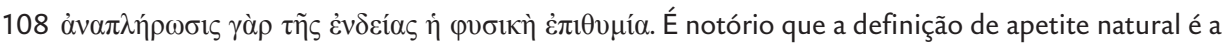
mesma que a de prazer corporal dada por Platão, em seu diálogo Filebo. A diferença, todavia, é que 
objetos prazerosos peculiares a cada um e, com relação a este, muitos erram de diversos modos. Também na Ética Eudêmia, quando Aristóteles procura definir o voluntário e distingui-lo do apetite, uma vez que é possível agir voluntariamente de modo contrário ao apetite, como ocorre no caso do controlado, o filó-

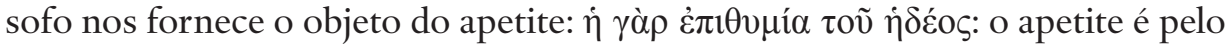
prazer (EE II, 6, 1223a35).

Há, porém, uma passagem em Ética Nicomaqueia III, 1, que poderia ser usada para refutar a definição do objeto do apetite como sendo o prazer. Ao procurar definir a ação voluntária e distingui-la da involuntária, Aristóteles diz que a ação por apetite ou impulso é voluntária, seja ela correta ou incorreta. Ademais, não só está em nosso poder agir por impulso e por apetite, como também é preciso aprender "a se encolerizar com algumas coisas e ter apetite por algumas coisas, como pela saúde e pelo estudo" (1111a32). Isso significa que o objeto do apetite não é apenas o prazer, mas também a saúde e o estudo? Ou significa que o objeto do apetite é sempre o prazer, seja ele qual for, como o prazer por comida, bebida e sexo, mas também por saúde e estudo? É mais provável que a segunda pergunta nos indique a resposta correta: o objeto do apetite é sempre o prazer e o prazer nada mais é do que uma sensação que temos ao realizar uma atividade prazerosa. Ora, a saúde e o estudo são atividades que devem se tornar prazerosas no decorrer do aprendizado moral. Além de reafirmarmos, com esta interpretação, que o prazer é o objeto por excelência do apetite, é possível inferir que o apetite é um tipo de desejo que pode se orientar pelo que a razão determina como sendo bom, visto que, por um lado, a saúde e o estudo são coisas boas e assim nos diz nossa razão, por outro, é preciso aprender a ter apetite, portanto, prazer com as atividades saudáveis e intelectuais. Neste sentido, o apetite pode ser dito como um desejo educável, isto é, capaz de obedecer ou ser persuadido pela razão.

o apetite não provém da dor, mas apenas o apetite do intemperante, pois, segundo Aristóteles, “ele sente dor não apenas quando ele não realiza o seu apetite, mas também quando ele o realiza, já que o apetite é com dor. Paradoxalmente, parece que a dor ocorre por causa do prazer" (1119a4-6). O erro (hamartia), continua o Estagirita, com relação a este tipo de apetite é menor e só ocorre quando há excesso. E normalmente quem erra, como o guloso, por exemplo, se comporta como um escravo de seus apetites excessivos. Já com relação aos apetites e prazeres peculiares, muitos erram e erram de muitos modos. O erro ocorre seja quanto ao objeto do apetite, seja quanto ao modo excessivo de se ter apetite. O intemperante erra por completo, tanto no que concerne ao apetite natural, como ao apetite peculiar. 
Com efeito, também na Retórica o filósofo distingue o apetite que é natural e irracional daquele que é racional, o que enfatiza a tese de que o apetite é educável:

Agradável é tudo aquilo que se tem apetite (epithumia), pois o apetite é o desejo pelo prazeroso. Dos apetites, uns são irracionais e outros racionais (meta logô̂). Denomino irracionais aqueles que ocorrem sem consideração prévia (hupolambaneîn) e tais são aqueles denominados naturais ( $p h u$ sei), como os que subsistem por causa do corpo - por exemplo, o desejo por alimentos, a fome, a sede, e o apetite conforme cada espécie de alimento; também aqueles que se referem ao paladar, aos prazeres sexuais e em geral ao tato, ao olfato, à audição e à visão. Por outro lado, denomino racionais os apetites que procedem da persuasão (ek tô̂ peisthênai), pois são muitas as coisas em que há apetite por contemplar e possuir por se ter ouvido (akousantes) e ter sido persuadido (peisthontes) (1370a17-27).

Como se pode notar, não apenas nas Éticas, mas também na Retórica, Aristóteles afirma explicitamente que o desejo pode ouvir e ser persuadido, no caso, o apetite, desejo por excelência mais avesso à atuação da razão em seu interior. Mesmo sendo o menos permeável, certamente ele pode ser educado e aqui está posta a condição de possibilidade, a saber: ele pode ouvir e ser persuadido pela razão, tornando-se, por isso mesmo, um desejo com razão ou conforme a razão (meta logoû), portanto, um desejo educado.

É-nos suficiente com relação ao apetite, passemos agora ao objeto do querer. O querer é um tipo de desejo que tem como objeto o bem ou o fim ${ }^{109}$ concebido pela razão. Primeiramente, é preciso dizer que será em Ética Nicomaqueia III, 4, 1113a15-b2, que Aristóteles definirá o querer. A boulêsis, diz ele, $\tau$ õ

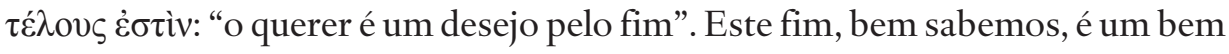
prático, isto é, uma ação que pareça ser boa para aquele que agirá. Há quem pense que ele seja o bem e que não poderíamos querer senão coisas realmente boas. Esta parece ser a tese defendida por Platão aos olhos do filósofo estagirita. Há também quem pense que ele é apenas o que parece ser bom para cada um, logo, o bem seria sempre bem aparente ou fenomênico. Esta parece ser a tese defendida por Protágoras. Contrapondo-se aos dois, Aristóteles defende que há tanto o bem absoluto (haplôs) e verdadeiro, como o fenomênico. A coincidência entre o 
que parece ser bom e o que é de fato ocorre quando a apreensão é correta, como no caso do virtuoso:

Se, então, estas posições não são satisfatórias, não se deve dizer que é objeto do querer sem mais (haplôs) e segundo a verdade o bem, enquanto o que aparece para cada um é o bem aparente? Assim, ao homem virtuoso é objeto do querer o bem segundo a verdade; ao homem de pouco valor, o que é aleatório, assim como, com respeito aos corpos, aos que estão em bom estado são saudáveis aquelas coisas que são tais segundo a verdade, aos que estão doentes outras o serão (e similarmente com as coisas amargas, doces, quentes, pesadas e outras deste tipo). Com efeito, o homem virtuoso julga corretamente cada coisa e em cada uma a verdade se manifesta a ele, pois há coisas belas e agradáveis próprias a cada disposição e presumivelmente o homem virtuoso se distingue sobretudo pelo fato de ver o verdadeiro em cada coisa, como se fosse um padrão e medida delas. À turba o engano, parece, engendra-se devido ao prazer, pois, não sendo um bem, parece ser. Buscam o prazeroso como um bem e evitam a dor como mal (1113a24-b1).

Desta passagem, interessa-nos apenas a concepção de que bem aparente e bem em absoluto podem coincidir ou não. Isso significa que o objeto do querer é sempre o que parece ser bom, e o que parece ser bom (bem fenomênico) pode ou não coincidir com o que é verdadeiramente bom (bem em absoluto). Esta coincidência ocorre no caso do virtuoso, pois o bem aparente ou que o parece ser bom coincide com o que de fato é bom. Nos demais casos, é possível que coincida ou não, a depender da disposição moral de cada agente e das circunstâncias em que o mesmo se encontra. Deste modo, o objeto do querer é sempre o que parece ser bom para cada um, isto é, um bem fenomênico, um bem apreendido por alguém. Com efeito, a categoria do bem e do mal é sempre relativamente a alguém, enquanto a categoria do verdadeiro e do falso é sempre em absoluto. ${ }^{110}$ Logo, o bem é sempre bem apreendido, mas nem sempre é

110 Neste ponto, tomo como referência o De Anima III, 7, 431b10-12: "quanto ao verdadeiro e ao falso que em nada dizem respeito à ação, pertencem ao mesmo gênero que o bom e mau, mas com a diferença que os primeiros são tais absolutamente, os segundos o são para alguém”. Ver também $D e$ Motu 6, 700b35, cuja expressão para bem relativo a alguém, em oposição a bem divino e ternamente belo, é "pros heteron". Tomás de Aquino elabora uma interpretação precisa do assunto: o bem é sempre bem apreendido (bonum apprehensum), e pode coincidir ou não com o bem in rei veritate (Suma Teológica la llae 8i). 
bem verdadeiro, isto é, ele pode ou não coincidir com o bem verdadeiro ou em absoluto, como ocorre no caso do virtuoso. Ademais, o que parece ser bom não coincide necessariamente com o que parece ser prazeroso, mas o que parece ser prazeroso necessariamente é o que parece ser bom. ${ }^{111} \mathrm{O}$ erro da maioria funda-se na crença de que basta perseguir o que é prazeroso para agir bem, pois o prazer parece ser um bem, embora nem sempre seja.

Se o objeto do querer é um bem fenomênico, então ele se constitui pelo que parece ser bom a alguém, ou seja, o que alguém pensa ser bom. Em Ética Eudêmia II, 6, ao negar que todo ato voluntário é feito por apetite, pois ele pode ser feito também por querer, o filósofo nos diz que "o que o homem quer fazer, ele faz voluntariamente, mas ninguém quer o que ele pensa ser um mal (ßov́ $\lambda \varepsilon \tau \alpha \iota ~ \delta$ '

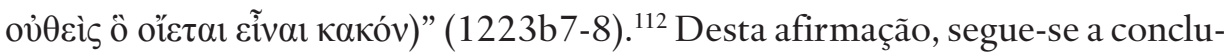
são de que o objeto do querer é o que pensamos ser um bem, o que implica não apenas o uso da percepção, mas de algum pensamento sobre o que é bom.

O mesmo observa-se em Ética Nicomaqueia V, 9, quando, ao procurar definir o que é uma ação injusta, o filósofo nos diz que é possível sofrer uma ação injusta que fora realizada voluntariamente, embora não seja possível sofrer de modo voluntário uma injustiça, pois ninguém quer ser prejudicado. Mesmo o descontrolado (acrático), que age voluntariamente contra o seu próprio querer, não quer algo que ele pensa não ser bom. Em verdade, diz o filósofo: "ninguém

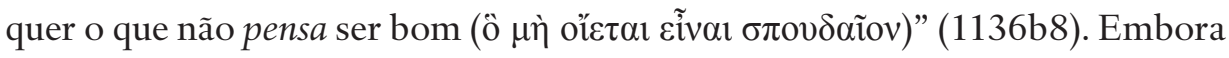
o descontrolado não queira, ainda assim ele faz o que ele pensa que não deveria fazer. E o faz, bem sabemos, por assim lhe apetecer. Também na Retórica I 10, Aristóteles, ao investigar as causas da ação injusta, diz algo semelhante: "quando são autores das ações, fazem umas por hábito e outras por desejo, seja por desejo racional ou irracional. O querer é um desejo pelo bem, pois ninguém quer algo senão quando pensa (oiêthêi) ser bom” (1369a1-4). Mais uma vez fica reiterada a tese de que o objeto do querer é o que se pensa ser bom. Isso significa que o querer parece ser o desejo mais afeito ao diálogo com a razão. ${ }^{113}$

111 Cf. De Motu, 6, 700b28-29.

112 A mesma afirmação se repete linhas adiante: $1223 \mathrm{~b} 33$.

113 Como argumento suplementar, é preciso salientar que o querer é mais afeito à razão e, por isso mesmo, naturalmente mais próximo da escolha deliberada, desejo racional por excelência. Podemos citar a passagem em que a escolha deliberada é definida por exclusão dos possíveis candidatos. Depois de ter excluído a opinião, o apetite e o impulso, o filósofo argumenta pela exclusão do que- 
É evidente, portanto, que os animais não possuem este tipo de desejo. No De Anima, procurando demonstrar que o intelecto não pode ser causa motora sem o desejo, o Estagirita diz que "quando alguém se move segundo o cálculo (kata ton logismon) também se move segundo o querer" (III 10: 433a24). O querer fora escolhido aqui justamente por ser ele o modo de desejar mais afeito à racionalidade; o que não significa dizer que ele próprio seja racional. Parece ser definitivamente estranho a ética aristotélica supor que um tipo apenas de desejo seria capaz de ouvir a razão e, mais ainda, que ele seria uma espécie de desejo da razão. Todavia, não é adequado tratar aqui novamente desta dificuldade gerada por uma interpretação enviesada de que o querer aristotélico é idêntico ao que ficou conhecido modernamente por vontade. ${ }^{114}$ Aceitemos como pressuposto que os três tipos de desejo são naturalmente desprovidos de razão, embora capazes de participar da razão, visto ser esta a característica do gênero desiderativo, ${ }^{115} \mathrm{o}$ desejo (orexis). O querer, certamente, é o desejo mais capaz de ouvir a razão, visto que o seu objeto é constituído por um pensamento sobre o que é bom.

É-nos suficiente quanto ao querer. Falemos agora do impulso. O impulso é um tipo de desejo cuja natureza é de menor clareza e cujo objeto é de maior amplitude, se compararmos com o apetite e o querer. Se o apetite é claramente o desejo pelo prazeroso e o querer pelo bem, o impulso parece se referir, sobretudo, à dor. Ele está certamente associado à cólera (orgê) na Retórica (1369a4) e ao encolerizar-se (orgizesthai) na Ética Nicomaqueia (1111a30-31).

Aristóteles, todavia, parece não fornecer, em nenhum lugar de sua obra, uma análise clara e conclusiva sobre este tipo de desejo; o que induz Urmson a declarar como pífio o seu papel na teoria ética aristotélica. ${ }^{116}$ Por outro lado, surpreendentemente, Grönroos afirma que o impulso é o desejo cujo papel é central na ética aristotélica por ser ele pivô para a compreensão de como a razão

rer como sendo o definiens de escolha deliberada. Assim, o querer não é escolha deliberada, "embora lhe seja evidentemente afim (suneggus)", ao contrário dos outros dois tipos de desejo, o apetite e o impulso, que nada possuem de semelhante com a escolha deliberada. Esta, por sua vez, não é um dos três tipos de desejo, embora seja um desejo sui generis, oriundo e conforme a deliberação pela realização do que nos conduz ao fim da ação; ao contrário dos três tipos de desejo que não se originam da deliberação, mas antes determinam o fim segundo o qual iniciamos a deliberação.

114 A questão já foi tratada na seção "Objeção: o conceito de vontade".

115 Cf. ENI 13: 1102b29-1103a1.

116 URMSOM, 1988, p. 41. 
participa da parte desiderativa. ${ }^{117}$ A meu ver, não parece que seja possível atribuir este papel centralizador ao impulso; tampouco Aristóteles creditar-lhe-ia a função de auxiliar a razão na educação do apetite, como fez Platão, no quarto livro da República. ${ }^{118}$

O impulso não parece assumir o glorioso papel daquele que preserva a razão ou a auxilia no combate aos apetites desviados, como gostaria Platão; tampouco estaria relegado ao esquecimento pela obscuridade de sua natureza. Este desejo, como veremos, é menos avesso à razão do que o apetite, pois que ele a ouve em certa medida. Quando se trata de uma injustiça, parece ser menos injusto sentir cólera ou um desejo impetuoso de reparação do que meramente perseguir prazeres e assim cometer um ato injusto. Sendo assim, em comparação ao apetite, sua desenvoltura parece ser mais elogiável e sua posição mais favorável no esquema geral da moralidade aristotélica; sem que ele, contudo, tenha que ser condecorado como fora por Platão. Vejamos então, no que se segue, o uso do critério da diferenciação pela participação na razão para sabermos quem ocupará o segundo e o terceiro lugares, visto que o querer já ocupa o primeiro lugar no que diz respeito à concordância com a razão.

\section{III}

Há uma passagem em que Aristóteles diz que "é mais difícil combater o prazer (hêdonê) do que o impulso (thumos)" (EN II 3: 1105a7-8), uma vez que o prazer é algo entranhado em nossa vida desde a infância e o apetite, como veremos, é um desejo mais avesso à razão. Ademais, o prazer é o fator motivador por

117 GRÖNROOS, 2007, p. 251-271.

118 Como vemos na República, Platão nos diz o seguinte: "o comandar cabe à razão, porque ela é sábia e cuida da alma toda, e à impetuosidade (thumoeidês) cabe ser submissa à razão e sua aliada" (441e). E, mais adiante: "E essas duas partes <a racional e a impetuosa>, tendo sido assim educadas, verdadeiramente ensinadas e formadas para cumprir sua tarefa, governarão a parte apetitiva (epithumêtikou) que, em cada um, é a maior da alma e, por natureza, é insaciável de riquezas. Ficarão de vigia para que ela não se encha dos chamados prazeres do corpo e, ao tornar-se maior e mais forte, deixe de cumprir sua tarefa e, embora isto não lhe caiba por sua natureza, tente escravizar e governar as outras e subverta a vida de todos" (442a). É oportuno também comentar que, em seu diálogo $\mathrm{Fe}$ dro, Platão compara os desejos não racionais a dois cavalos arredios ao domínio da razão que tenta comandá-los de modo a guiar a carruagem: o impulso é como um cavalo fogoso, mas obediente à razão, enquanto o apetite é como um cavalo esquivo, que puxa para esquerda, sempre tentando furtar-se ao comando da razão. 
excelência das ações para a maioria das pessoas, visto que tudo o que é prazeroso também parece ser bom. Por tais razões, podemos concluir que é muito mais difícil combater o prazer, portanto, o desejo pelo prazer do que o impulso; o que nos exige toda disciplina (pasa pragmateia) possível quanto aos prazeres (1105a5). Tanto com relação ao prazer e ao apetite, como quanto à dor e ao impulso, devemos saber ser afetados da melhor maneira possível e nos comportarmos bem; porém, é mais difícil se disciplinar e cultivar bons hábitos no que concerne aos prazeres do que às dores.

Passemos, neste momento, ao ponto que sobremaneira nos interessa: em que sentido o impulso é menos avesso à razão comparativamente ao apetite? Esta pergunta só poderá ser respondida se analisarmos o capítulo 6 do livro VII da Ética Nicomaqueia (1149a25-1150a8), capítulo em que Aristóteles distingue o descontrole (acrasia) por apetite daquele por impulso, no intuito de assim delimitar o descontrole estrito senso (haplôs).

Depois de ter demostrado, no capítulo 5, que o descontrole é distinto da bestialidade, visto que seu objeto não são os prazeres bestiais, mas sim os corporais necessários, isto é, os mesmos do escopo da intemperança, Aristóteles conclui que todo descontrole que não tenha como objeto os mesmos da intemperança (akolasia) deve ser dito descontrole por metáfora e não estritamente ou sem qualificação (haplôs). Por isso, aquele por apetite é dito descontrole estritamente e o por impulso é dito metaforicamente ou por homonímia descontrole.

Tendo assim concluído o quinto capítulo, no capítulo subsequente, o filósofo expõe, através de quatro argumentos, a seguinte tese: o descontrole por apetite é mais vergonhoso ou grave (aischion) do que aquele por impulso. Com o intuito de bem distinguir e delimitar esses dois fenômenos de descontrole, as diferenças entre o impulso e o apetite foram pontuadas com tal minúcia que não encontramos em outro lugar da Ética Nicomaqueia. O que nos interessa deste detalhamento é antes conhecer a natureza de tais desejos do que o próprio fenômeno acrático.

No início do sexto capítulo, o filósofo afirma que é mais vergonhoso o descontrole por apetite do que por impulso, o que significa dizer que é mais grave, do ponto de vista moral, errar por apetite do que por impulso e isso por quatro argumentos. Apresentarei brevemente tais argumentos, destacando os atributos desses desejos. O primeiro argumento (1149a25-b3) mostra a relação do impulso e do apetite com a razão, revelando que o impulso é mais permeável ao diálogo com a razão do que o apetite, ou seja, enquanto o impulso ouve de certo 
modo a razão, o apetite não a ouve em absoluto. Nas palavras do filósofo estagirita: "o impulso parece ouvir (akouein) de certo modo à razão, mas a ouve incorretamente (parakoueîn)” (1149a26-7). Já o apetite não a ouve de modo algum (1149b1-2). O impulso ouve a razão como um servente que sai apressadamente antes de ter recebido a ordem inteira ou como um cachorro que late ao primeiro toque na porta sem esperar para ver se é um amigo. Como nos diz o filósofo:

O impulso, devido ao calor e à impetuosidade de sua natureza, embora ouça (akousas), não escuta a ordem (epitagma akousas), e se impulsiona (hormâi) para a vingança. Isso porque quando a razão (logos) ou a imaginação (phantasia) diz que um ultraje ou um desprezo foi recebido, o impulso, como que tendo raciocinado que alguém desse tipo deve ser combatido, imediatamente se manifesta. $\mathrm{O}$ apetite, por outro lado, se a razão (logos) ou a sensação (aisthêsis) apenas diz que algo é prazeroso, ele se impulsiona para deleitá-lo. Portanto, o impulso como que ouve a razão (logos) de certo modo, mas o apetite não (EN VII 6, 1149a30-6).

A conclusão dessa passagem não parece ser tão evidente a partir do que foi dito antes. É preciso um esforço exegético para compreendê-la. Pois bem, do que foi dito podemos interpretar do seguinte modo. $\mathrm{O}$ impulso, quando não educado, se precipita à ação antes mesmo de ouvir ou compreender o que diz a razão. E porque não a ouve bem ele não a obedece inteiramente, mas apenas em parte ou de modo distorcido. Esta razão que o impulso não obedece por completo ou que ouve de modo distorcido é aquela que diz que um insulto foi cometido.

Já o apetite, quando não educado, sequer ouve o que diz a razão sobre o que é justo ou o que é preciso ser feito, mas apenas se impulsiona surdamente ao que é prazeroso tal qual fora concebido por um pensamento ou uma percepção. Como atesta o filósofo em outra passagem, aquele que vive em função de seus prazeres "não escutará um conselho moral, nem mesmo o compreenderá" (EN $\mathrm{X}$ 10, 1179b26-28). Ademais, não há contradição em dizer que um logos constitui o objeto do apetite e que o apetite não ouve de modo algum o logos, se, neste caso, supusermos que este último se refere ao orthos logos, à reta razão, àquela que apreende verdadeiramente o que deve ser feito e assim aconselha, enquanto o primeiro se refere ao sentido corrente de logos, isto é, de um pensamento que, neste caso, concebe algo como prazeroso. ${ }^{119}$ 
Devemos também fazer outra ressalva quanto à afirmação de que o apetite não ouve de modo algum a reta razão. Trata-se aqui do apetite do descontrolado e do intemperante e não do apetite em geral. Não poderíamos dizer que o apetite é, por natureza, excessivo, desregrado e contrário à razão. Ele é por natureza educável, visto o caso do temperante cujo apetite já educado ouve e obedece mais facilmente à reta razão. Todavia, em uma situação em que ambos os desejos não são educados, o apetite é mais vergonhoso e censurável do que o impulso desregrado. Isso significa que é mais vergonhoso seguir simplesmente o que lhe dá prazer, desconsiderando completamente o que é correto, do que reagir a uma dor e seguir em parte o que é correto. Ou seja, o descontrole com relação ao apetite é mais vergonhoso ou censurável, portanto, menos aceitável do que aquele por impulso.

Para entendermos por que o impulso deseducado ouve em parte ou de modo destorcido a razão, devemos nos atentar para o fato de que, segundo o Estagirita, o ser humano, quando se encontra sob um estado passional excessivo, como uma emoção ou um desejo excessivo, tem a sua capacidade perceptiva alterada e, consequentemente, sua capacidade cognitiva em geral afetada, fazendo variar os seus julgamentos ou discernimentos (kriseis). ${ }^{120}$ Isso significa que o impulso e o apetite, quando excessivos, provocam certa alteração cognitiva no indivíduo. Ademais, a força de atuação do apetite deseducado é tamanha que, mesmo que a razão diga para "evitar isto, o apetite conduz para isto, pois ele pode mover cada parte do corpo" (ENVII 3: 1147a35-6). Também nos diz o filósofo que o apetite do descontrolado é ele próprio contrário à reta razão e a opinião que o acompanha é contrária apenas por acidente (1147b3). Neste caso, é por estar sob um estado passional intenso que a percepção é conduzida pelo apetite, fazendo com que o conhecimento sobre o que é correto permaneça em potência, ou que seja atualizado apenas em palavras, e não em ação. A condição do descontrolado é similar a do adormecido, louco ou bêbado: todos são capazes de reconhecer e dizer o que é certo, mas não são capazes de orientar suas ações conforme o que é certo (1147a10-20).

tites são, de modo geral, contrários à razão (para ton logon), mas a cólera é com razão (meta logou); não uma razão que ordena a cólera, mas que sinaliza o insulto ou a acusação" (XXVIII, 3, 949b1719). Ou seja, a reta razão ordena, limita, direciona corretamente a emoção e o desejo, e é justamente esta razão que o apetite acrático não é capaz de ouvir.

120 Sobre este ponto, ver Ret. II 1: 1378a19-22. 
Em linhas gerais, podemos dizer que a percepção, neste caso, passa a ser governada pela imaginação quando ocorre uma ignorância (agnoia) momentânea decorrente dos estados passionais intensos (1147a10-b9). Assim como os que se encontram dormindo, loucos ou bêbados, "pessoas em estados passionais (en tous pathêsin ontes) estão na mesma condição; pois os impulsos e os apetites sexuais, além de outras afecções, alteram o corpo e, em alguns casos, causam loucura" (1147a15-17). Ou seja, alguns estados passionais alteram o funcionamento regular do corpo e podem chegar a atrofiar inteiramente a razão, levando à loucura, como nos casos de impulsos e apetites extremos (1147a11-8). Sabemos que são fortes os apetites que movem o descontrolado, na medida em que tal desejo é capaz de pôr cada parte do corpo em movimento (1147a35) e produzir um estado de ignorância momentânea ao "arrastar" (perielketai) o conhecimento perceptivo (1147b18); diferentemente do perverso ou do intemperante, que é movido por fracos apetites (1148a18-20). ${ }^{121}$

Voltando ao trecho que estamos analisando, 1149a30-6, podemos dizer que ele nos possibilita compreender melhor a natureza dos desejos não racionais, cujo objeto pode ser constituído pela razão, imaginação ou sensação. O objeto do impulso parece ser a dor do ultraje, insulto ou desprezo, e o do apetite é o prazer. A definição de cólera da Retórica também confirma que a dor do ultraje, desprezo ou desdém seja o objeto do impulso por vingança ou justiça, a saber: "Seja, então, a cólera um desejo acompanhado de dor de vingança por causa de um manifesto desprezo contra si mesmo ou contra alguém próximo, sem que o desprezo seja merecido" (Ret. II 2: 1378a30-2). Isso significa que o desejo não é simplesmente um movimento irracional no sentido de ser absolutamente fechado à atuação da razão em seu interior.

O desejo é um movimento que surge a partir de um objeto concebido pela razão, imaginação ou sensação. Para que haja impulso ou apetite é preciso haver uma consideração sobre a dor ou o prazer de modo que algo nos pareça prazeroso ou doloroso. No caso dos animais, certamente, esta consideração é apenas uma apreensão sensível, isto é, uma imagem formada a partir da percepção atual

121 O tema da alteração da percepção em estados passionais intensos mereceria um capítulo à parte. Em suma, teríamos que, a partir da análise do Tratado do Sonho, compreender a atuação da função onírica da imaginação nesses estados passionais; estados nos quais a percepção é turvada pelos afetos, deixando de executar o seu papel de bem discriminar e, por isso, provocando consequências negativas à ação. Contudo, deixemos tal análise para outro momento. 
de algo prazeroso ou doloroso. Esta imagem é fruto da função denominada pelo filósofo de imaginação sensível. Já no caso dos homens, tanto a imaginação sensível como a racional podem constituir o objeto de desejo.

Em De Anima III 9-11, Aristóteles explica que a atuação da imaginação na constituição do desejo pode se dar de dois modos: enquanto imaginação racional ou sensível. Isso pressupõe ao menos três teses importantes sobre a constituição do desejo: (i) em primeiro lugar, não há desejo sem imaginação, portanto, a imaginação é causa necessária do desejo; (ii) em segundo lugar, a imaginação é produzida seja a partir de um objeto sensível, seja a partir de um objeto noético; e, (iii) como não basta perceber ou pensar para desejar, é necessário que haja imaginação para tanto, então, algo percebido ou pensado deve nos aparecer como sendo um bem para que seja objeto de desejo, e este aparecer como um bem é próprio da função imaginativa cujo objeto é uma aparição (phantasma).

Quanto à primeira tese, Aristóteles repete em diversos momentos no De Anima e no De Motu Animalium que não há desejo sem imaginação, citemos apenas uma passagem bastante contundente a este respeito: "É na medida em que o animal é capaz de desejar que ele pode mover-se a si mesmo, e a capacidade desiderativa não existe sem imaginação, sendo toda imaginação racional (logistikê) ou sensível" (DA III, 10, 433b27-29). Ademais, se o desejo necessita da imaginação, também a imaginação necessita do desejo quando sua função não é cognitiva, mnêmica ou onírica, mas desiderativa e, portanto, prática: "a imaginação, quando move, não move sem o desejo” (DA III 10, 433a20). Enfim, a imaginação é necessária ao movimento por dois motivos: ${ }^{122}$ (i) os animais não racionais são capazes de desejar e se moverem por terem imaginação, pois não é suficiente perceber para agir, ${ }^{123}$ é preciso ter imaginação para que um objeto percebido também pareça ser prazeroso e bom; (ii) a imaginação é como um pensamento, ${ }^{124}$ portanto, no caso dos animais racionais, ela faz a vez do pensamento na constituição do objeto de desejo, afinal não é suficiente pensar para agir, ${ }^{125}$ é preciso ter imaginação para que um objeto pensado também pareça ser bom.

122 Cf. DA III 10, 433a9-12.

123 Caso contrário, a sensação seria causa suficiente do movimento, o que é falso (DA III 9).

124 Cf. DA III 10, 433a10.

125 Caso contrário, o intelecto seria causa suficiente do movimento, o que é falso (DA III 9). 
Que a imaginação é produzida a partir de nossas percepções e pensamentos é evidente não apenas pelo que foi dito acima, mas também por ela ser denominada tanto sensível ou que provém da sensação, quanto racional, isto é, quando provém do pensamento. Quanto a essa segunda tese, há uma passagem exemplar no De Motu que explica a origem do desejo na imaginação e a transmissão do desejo para o corpo de modo a engendrar o movimento: "As afecções (pathê) preparam as partes orgânicas adequadamente, o desejo prepara as afecções, e a imaginação, o desejo; esta, por sua vez, se gera ou pelo pensamento (dia noêseôs) ou pela sensação" (702a17-19).

A terceira tese é mais complexa e nos exigirá um maior esforço para sustentá-la. Por vezes Aristóteles se refere à imaginação como aquela responsável pelo movimento dos animais e, no caso do homem, apenas quando este age similarmente aos animais, fazendo a vez do pensamento quando o intelecto está obscurecido pelas emoções, como é o caso do acrático, dos loucos, doentes e bêbados. ${ }^{126}$ Todavia, nos capítulos 9, 10 e 11 do De Anima, capítulos que compõem uma espécie de teoria da causa do movimento dos animais e da ação humana, o filósofo alarga a contribuição da imaginação como causa do movimento e lhe atribui um aspecto positivo, visto que, em termos gerais, só é possível desejar com imaginação, seja quando ela faz a vez do pensamento prático na constituição do fim da ação (imaginação racional), seja quando ela faz a vez da percepção (imaginação sensível).

A imaginação foi definida pelo filósofo como um certo movimento produzido pela atividade perceptiva ${ }^{127}$ e como "aquilo segundo o qual dizemos ocorrer em nós uma imagem (phantasma)” (DA III, 3, 428a1-3), ou seja, um movimento oriundo da atividade perceptiva a partir do qual surge em nós uma imagem. É claro que a definição é ampla e visa contribuir tanto para a teoria do conhecimento, como para a teoria da ação na filosofia aristotélica. No que diz respeito à ação, esta imagem que surge em nós deve ser compreendida como uma representação, no sentido de aparição na alma, de um bem ou uma consideração sobre o que é bom para alguém, caso contrário, a imaginação

126 De Anima III, 3, 429a4-8: "porque as imagens (phantasmata) perduram e são semelhantes às sensações, os animais realizam muitas ações (prattei) conforme tais imagens, sejam os brutos (thêria), por não terem intelecto, sejam os homens, por terem o intelecto obscurecido pela emoção (pathêi) ou pela doença ou por sono".

127 Cf. DA III, 3, 428 b11. 
não constituiria desejo algum e nem seria capaz de mover o animal. É preciso, portanto, que eu tome algo como sendo um bem para que este algo se torne meu objeto de desejo. Certamente, o desejo é fruto de uma consideração particular e subjetiva sobre o que me parece ser bom conforme certas circunstâncias. ${ }^{128}$ Trata-se do conhecido bem fenomênico ou bem apreendido, como já nos referimos acima.

Novamente, o bem é sempre o que parece ser bom para alguém e, na medida em que parece ser bom, uma imagem se produz na alma daquele que assim considera, percebe ou pensa. Ao investigar o que é que move o animal, Aristóteles nos diz, no De Motu 6, que é o objeto de desejo (orekton) e este é o fim das ações (to tôn praktôn telos), portanto, um bem. Ademais, todo fim é um bem e "todo desejo é do fim" (DA III 10, 433a15). Não qualquer bem, mas o bem prático (to prakton agathon), isto é, aquele em vista do qual agimos e que, portanto, causa movimento. ${ }^{129}$ Este bem é sempre um bem relativo a alguém que assim o apreende, ou seja, é o bem aparente, ou, nas palavras do filósofo: "é preciso estabelecer também que o bem aparente (phainomenon agathon) ocupa um lugar de bem, e também o prazer, pois é um bem aparente" (De Motu 6, 700b28-29). Isso significa que o bem aparente também é um bem, mesmo que seja apenas aparente e não verdadeiro, todavia, não deixa de ser, por isso, um bem. O objeto de desejo, causa primeira da ação, é o fim, portanto, um bem aparente que pode ou não ser também verdadeiro, como já foi dito.

O prazer, por sua vez, necessariamente é bem aparente, pois tudo o que parece ser prazeroso também parece ser bom, embora nem tudo o que pareça ser bom também pareça ser prazeroso, como mostra claramente o conflito moral. No conflito, há, de um lado, um bem oriundo do pensamento ou da imaginação racional, que é objeto do querer, e, de outro, um bem advindo da imaginação sensível, que é objeto do apetite. O objeto do querer é o que pensamos ser bom, portanto, uma imagem do que nos parece ser bom segundo a imaginação racional, e o objeto do apetite é o que percebemos ser prazeroso,

128 Cito um exemplo de silogismo prático, segundo Aristóteles, cuja conclusão é uma ação: “Devo fazer um bem para mim (poiêteon moi agathon), a casa é um bem. Faço uma casa imediatamente" (De Motu, 7, 701a16-17).

129 DA III 10, 433a19: “o objeto desejado (orekton) move e devido a isto o pensamento (dianoia) move, pois que o princípio do pensamento é o objeto de desejo”. Cf. também DA III 10, 433a27-30. 
portanto, uma imagem do que nos parece ser bom por parecer ser prazeroso segundo a imaginação sensível. Enfim, há objeto que parece ser bom simplesmente porque pensamos que é bom e há objeto que parece ser bom porque parece ser prazeroso.

A imaginação sensível, no que diz respeito ao ato de desejar, estará rente ao presente e será associada à percepção do prazeroso e do doloroso. Ao contrário, a imaginação racional envolve cálculo, ou seja, diante das imagens sensíveis presentes, o homem é capaz de raciocinar sobre o futuro, freando, como no caso do controlado, um desejo pelo prazer imediato. ${ }^{130}$ A imaginação, como se nota, exerce um papel importante na constituição do objeto do apetite, o que é evidente no conflito moral. Com efeito, Aristóteles nos diz em De Anima III 10, 433b5-12, que o conflito surge quando há, na alma, desejos contrários, portanto, quando a razão (logos) é, concomitantemente ao querer, contrária ao apetite. ${ }^{131} \mathrm{O}$ intelecto (nôิs) ordena resistir por causa do futuro e o apetite segue o agora, porque o prazeroso parece ser (phainetai) absolutamente prazeroso e bom no presente. Por não ver o futuro e diante de uma imaginação (phantasia) sobre o prazer imediato, o apetite conduz o descontrolado para a ação que o satisfaça. Já no caso do controlado, a razão vence o apetite na medida em que o querer vence $o$ apetite. ${ }^{132}$

Exponho, ainda, mais um argumento a partir do qual é possível inferir que a imaginação atua na constituição do objeto do apetite. Com efeito, sentir prazer ou dor difere de considerar ou imaginar algo como sendo prazeroso ou doloroso. O primeiro é decorrente de uma operação perceptiva, o segundo de uma operação imaginativa. Imaginar algo como prazeroso é apreendê-lo como algo que será bom, como bem aparente, logo, é desejá-lo. Há uma passagem decisiva para compreendermos que o desejo pelo prazeroso é uma imagem do que é percebido ou pensado como prazeroso:

A sensação é, então, como a simples asserção ou simples pensamento (noeîn) e quando há algo prazeroso ou doloroso, a sensação, como que

130 Cf. DA III, 7, 431b2-10; III, 10, 433b5-12.

131 Como já foi dito, a razão não é por si mesma contrária ao apetite, senão que ela é contrária na medida em que o querer que lhe acompanha é contrário, visto que o querer é sempre um desejo conforme a razão.

132 Cf. DA III 11, 434a12-15. 
afirmando ou negando, busca ou evita. Com efeito, sentir prazer e dor é exercer uma atividade, por meio da faculdade perceptiva, em direção ao bem ou ao mal enquanto tais. Nisto consiste evitar e desejar em ato (kat'energeian); e não diferem entre si as faculdades desiderativa (orektikon) e a que evita, nem diferem da perceptiva (aisthêtikê); embora difiram quanto ao ser. E, para a alma pensante (dianoêtikê psychê), as imagens são como sensações presentes: quando afirma ou nega o bem ou o mal, evita ou busca (por causa disso, a alma nunca pensa sem uma imagem) (DA III 7: 431a8-16).

Este trecho nos é útil apenas para inferirmos que a atuação da imaginação no interior do desejo implica que o objeto desejado seja fruto de uma consideração imaginativa sensível ou racional. Assim, estamos autorizados a fundamentar a tese de que o pensamento atua sobre o desejo quando afirma ou nega que algo é bom ou ruim, ou seja, quando imagina racionalmente que algo é bom ou ruim. Imaginar algo bom ou ruim corresponde a ter uma sensação presente de que algo é prazeroso ou doloroso. Certamente, não é qualquer pensamento que atua no interior do desejo constituindo o seu objeto. Trata-se de um pensamento prático ou sobre as ações, que faz uso da imaginação, pois ela é capaz de pôr diante dos olhos uma imagem com efeito similar à sensação, como se nota na citação acima: "para a alma pensante (dianoêtikê psychê), as imagens são como sensações presentes: quando afirma ou nega o bem ou o mal, evita ou busca”. Sendo assim, Aristóteles complementa o argumento dizendo:

Assim também quando nas sensações está determinado por ela o que há de ser perseguido ou evitado, também move quando, fora da sensação, se volta às imagens (phantasma); por exemplo, quando alguém percebe uma tocha, que é fogo, e < pelo sentido comum>, vendo que se move, reconhece que é o inimigo. Outras vezes, alguém calcula e delibera sobre o futuro diante do presente como que vendo por meio de imagens ou pensamentos (noêmasin) na alma. E quando diz que ali está o prazeroso ou o doloroso, aqui se evita ou busca, e assim ocorre em geral com as ações (DA III, 7, 431b2-10). ${ }^{133}$

133 Outra passagem que descreve bem a atuação do pensamento no interior do desejo é a seguinte: "Com efeito, as sensações resultam imediatamente em alterações; a imaginação e o pensamento (noêsis) têm a potência das coisas, pois, de certo modo, a ideia (eîdos) pensada de calor ou de frio ou de prazer ou de temível acontece de ser tal como é cada uma dessas coisas, e por isso se tem frio e medo somente pensando" (De Motu 7, 701b18-22). A Retórica de Aristóteles nos forneceria um 
Em suma, havendo tal sensação ou pensamento, o desejo de busca ou de aversão se segue. ${ }^{134}$ Assim, parece ser possível estabelecer o seguinte pressuposto: o desejo é constituído seja pela imaginação sensível, que provém de uma sensação presente sobre o prazeroso ou doloroso, seja pela imaginação racional, que provém de um pensamento sobre o que parece ser bom. Esse pressuposto é fundamental para conceber a natureza do desejo como sendo permeável à razão, ou seja, para compreender que a razão pode efetivamente participar da parte desiderativa por meio de uma operação imaginativa. Essa operação racional que atua via imaginação na constituição do desejo pelo fim não é a deliberativa, pois esta incide apenas sobre os meios; embora tenha que ser algum tipo de operação racional, pois que é um juízo acertado sobre o que é bom que constitui o bom fim, conforme já estabelecido.

Voltemos à distinção entre o descontrole por apetite e aquele por impulso. Até o momento, vimos que ambos os desejos são motivadores de ações voluntárias, mas que a ação incorreta feita por apetite é mais censurável do que a por impulso, visto que o apetite em nada ouve a reta razão, enquanto o impulso a ouve de alguma maneira. Mesmo assim, a natureza de ambos os desejos é ser capaz de ouvir de certo modo a reta razão, ou seja, é ser capaz de ser educada, visto que tanto o impulso como o apetite podem ser persuadidos pelo o que a razão apreende como sendo verdadeiramente um bem.

Feita a análise do primeiro argumento para mostrar que a acrasia por apetite é mais vergonhosa do que aquela por impulso, visto que o impulso ouve em parte a razão, enquanto o apetite em nada a ouve, bem como as suas consequências para o entendimento da natureza desses dois desejos, passemos para a análise do segundo argumento, fornecido em 1149b4-13, que demonstra que o impulso é mais natural do que o apetite excessivo e, por isso mesmo, o erro por impulso é mais desculpável ou perdoável do que aquele cometido por apetite excessivo, uma vez que "o impulso e o temperamento ruim (chalepotês) são mais

bom material para tratar do assunto, mas a minúcia nas emoções próprias à retórica não seria útil para o nosso propósito.

134 Veja o que o filósofo afirma sobre a conexão das funções anímicas sensitiva, imaginativa e desiderativa: "se há sensação, então há imaginação e desejo; pois onde há sensação, há também prazer e dor, e onde eles existem, também existe necessariamente apetite" (DA II 2: 413b22-24). Em outros momentos, o pensamento também é tido como causa do desejo, como já vimos, e como é evidente na seguinte citação: “A causa última do movimento é o desejo, e este origina-se pela sensação, pela imaginação e pensamento (noêseôs) (De Motu 7, 701 a35-36). 
naturais do que o apetite por objetos excessivos e desnecessários” (1149b7-9). Ou seja, a cólera ou o impulso são mais próprios de nossa natureza do que os apetites desviados. Por isso, Aristóteles afirma que é mais comum existir o colérico do que o apático, uma vez que a vingança é uma emoção mais própria à natureza humana do que a sua absoluta ausência (1126a30).

Diríamos o mesmo com relação aos apetites por prazeres necessários não excessivos, ou seja, que eles são próprios, ou melhor, mais próprios à nossa natureza do que os excessivos. São prazeres necessários aqueles relacionados à comida, bebida e sexo, isto é, aqueles relativos ao tato e ao paladar que visam exclusivamente a preservação da vida (1147b23). Com efeito, a privação desses objetos necessários naturalmente causa dor e até podem causar o perecimento. ${ }^{135} \mathrm{O}$ prazer necessário é aquele que acompanha as atividades que preservam a vida, sendo prazeroso conforme a natureza.

Quando se trata da busca do prazer pelo prazer, independentemente de sua necessidade para a preservação da vida, temos não mais o prazer necessário desejado em função da vida, mas aquele que é desejável por si mesmo ( $t a$ haireta kath'auta) e, por isso mesmo, suscetível de excesso (huperbolên). ${ }^{136}$ Os apetites por prazeres desnecessários e excessivos são normalmente entendidos como antinaturais, como contrários à natureza humana, à nossa racionalidade, e são, certamente, adquiridos por maus hábitos. Logo, o impulso, enquanto reação natural e imediata à dor sofrida, é mais natural do que o apetite excessivo e, sendo assim, o segundo argumento demonstra que é mais desculpável (suggnômê) uma ação motivada por uma reação à dor do que pela busca de prazer excessivo.

O terceiro argumento (1149b14-20) mostra qual seria o objeto do impulso, bem como os atributos próprios à natureza de cada desejo comparativamente. Neste momento, Aristóteles afirma que a manifestação do impulso, bem como da emoção correspondente, a cólera, é clara ou transparente (phaneros);

135 É por isso que o tato, órgão primário e primordial para a vida do animal, é fundamental para evitar a dor que pode ser, inclusive, fatal, se o sensível tátil for excessivo (por exemplo, o calor, o frio e a dureza ou agudeza de um objeto) (DA III 13: 435b14). Como diz o filósofo, o animal "tem tato sobre o prazeroso e o penoso, por meio do qual pode perceber o que é prazeroso na comida e ter apetite e mover-se" (DA III 13: 435b22-4). Com efeito, “um ser que não tenha sensação, no contato com as coisas, não poderá evitá-las ou capturá-las. E, se assim for, será impossível para o animal preservar-se" (DA III 12: 434b16-18).

136 Ver EN III 13: 1118b16-19 e VII 4: 1147b23 e ss. 
enquanto a manifestação do apetite é ardilosa ou manipuladora (epiboulos) por iludir, enganar, incitar. Neste trecho, Aristóteles compara o apetite com Afrodite, dizendo que sua natureza é como a da deusa "tecedora de enganos/ nascida em Cyprus" (1149b16). Homero, por sua vez, diz: " $<$ sua > fita bordada e variegada (kesto) na qual estavam urdidos todos os encantamentos: nela está o amor, nela está o desejo, nela está o namoro e a sedução, que rouba o juízo aos mais ajuizados" (Ilíada, XIV, 214-217). ${ }^{137}$

Já o impulso, cuja natureza é antes impetuosa (tachutêta) do que manipuladora, mostra-se como tal. Sua natureza é a do combate, da luta, da guerra. Sua sede é por justiça, por vingança. Sua manifestação surge da dor da injúria, desprezo, ultraje. A natureza do apetite, por sua vez, é a da sedução, da manipulação, da trama. Seu objetivo é o prazer, mesmo que para isso tenha que lançar mão do ultraje, do engano, da ilusão. Portanto, sua manifestação surge do prazer de, se for o caso, ultrajar, ludibriar, seduzir. Analogamente, em uma situação de traição, diríamos que o impulso é mais natural à vítima do ultraje, enquanto o apetite, àquele que ultraja. Com as palavras do filósofo, fazemos jus à nossa interpretação: "ademais, ninguém ultraja sofrendo, e todo aquele que age por cólera (orgê), age sofrendo, e aquele que ultraja, age com prazer" (1149b20-21). ${ }^{138}$ Logo, como é dito em seguida no texto, quanto mais injusto for o ultraje, mais justo é o encolerizar-se e, certamente, o impulso suscitado na vítima de um ultraje é mais justo do que o apetite daquele que ultraja. Isso significa que a ação por impulso é, em certa medida, uma ação coagida pelo sofrimento; ela é em parte uma reação dolorida a um insulto ou desprezo desmerecido, portanto, o seu objeto é uma injustiça ou o que parece ser uma injustiça. ${ }^{139}$ Enfim, a reação impetuosa parece ser, neste caso, menos voluntária que a ação por apetite, pois nesta última nenhum tipo de provocação injusta a motivou, nem pesa sobre o agente qualquer sofrimento. Por isso, o erro advindo da ação voluntária prazerosa é moralmente mais grave do que o erro cometido por uma ação voluntária dolorosa; logo, a acrasia por apetite é mais grave do que a acrasia por impulso. ${ }^{140}$

137 Tradução de Frederico Lourenço, llíada, Lisboa, 2005.

138 O mesmo é dito em Retórica II 3: 1380a34-36.

139 Que o objeto do thumos é o que parece ser uma injustiça ou uma injustiça fenomênica também é dito em EN V 8: 1136a29: epi phainomenêi adikiai hê orgê esti.

140 Tomás de Aquino (1993, § 1396) defende que a ação por impulso é uma ação mista de voluntário e involuntário. Todavia, nós preferimos optar por uma interpretação de graus de voluntariedade; 
O quarto e último argumento, 1149b20-26, mostra que o impulso pode ser entendido como uma espécie de reação à dor sofrida por ultraje ou insulto, o que confere à ação por impulso um caráter menos voluntário do que a ação por apetite. Com efeito, a traição ou ultraje (hubrizei) é cometido antes por prazer do que por dor; portanto, antes por apetite do que por impulso. Por este argumento, além dos outros três, a ação indevida cometida por apetite é mais injusta, vergonhosa, grave, portanto, menos desculpável do que a realizada por impulso.

Ademais, podemos endossar essa análise comparativa entre o apetite e o impulso a partir da comparação entre temperança e coragem, virtudes relativas ao apetite e ao impulso respectivamente, visto que a tese de que a intemperança é mais voluntária do que a covardia se fundamenta no argumento de que a ação por apetite é mais voluntária do que a por impulso: "pois uma é por prazer, e a outra por dor e o prazer é buscado (haireton), enquanto a dor é evitada (pheukton)" (EN III 12: 1119a21-22).

\section{IV}

Por fim, pretendi com este texto demonstrar que, embora Aristóteles não os tenha explicitado, é possível constatar a existência de dois critérios que estabelecem com clareza a diferença específica entre os três desejos. Além da diferença pelo objeto, as espécies de desejo diferem por sua natureza permitir mais ou menos participação da razão em seu interior. Quanto ao objeto, ficou demonstrado que o objeto do querer é o que me parece ser bom, ou seja, o que eu penso ou imagino racionalmente ser um bem; o do apetite, o que me parece ser prazeroso, portanto o que percebo, penso ou imagino sensivelmente ser prazeroso e bom; e o do impulso, o que me parece ser uma injustiça dolorosa, isto é, o que percebo, penso ou imagino sensivelmente ser um desprezo ou insulto sofrido desmerecidamente. Quanto à participação na razão, o querer é o desejo por natureza mais capaz de ouvir e obedecer à razão, enquanto o impulso e o apetite são por natureza menos capazes, mas educáveis para serem conforme a razão. O impulso, todavia, parece ser mais capaz de ouvir a razão do que o apetite, pois mesmo deseducado, consegue ouvi-la em parte, enquanto o apetite deseducado 
em nada a ouve. Quando educados, há um diálogo harmonioso com a razão, como ocorre na alma do virtuoso. ${ }^{141}$

Vejamos, neste momento, como exatamente ocorre esta comunicação persuasiva entre a razão e o desejo de modo que a razão seja capaz de participar do desejo educando-o.

\section{Razão e desejo: uma comunicação persuasiva ${ }^{142}$}

Por vezes nos encontramos em uma situação que nos exige refletir e aconselharmos a nós mesmos; outras vezes, ouvimos conselhos dados por outros, como os familiares e amigos. Todavia, nem sempre de fato ouvimos. Ou às vezes ouvimos, mas não seguimos este ou aquele conselho, mesmo acreditando em certa medida que segui-lo seria o melhor. E neste diálogo consigo mesmo, há algo em nós que nos impulsiona a agir como que independentemente de nós mesmos, contrariando o que pensamos que é o melhor a ser feito. Certamente, todos nós já vivemos uma espécie

141 Nas belas palavras do filósofo: “Uma outra natureza da alma, <o desejo>, também se mostra ser não-racional, participando, porém, em certa medida, da razão. Com efeito, elogiamos, no homem que se controla e no acrático, a razão e a parte racional da alma, pois ela exorta corretamente às melhores ações, mas também se manifesta neles uma outra parte, por natureza contrária à razão, que combate e puxa em sentido contrário à razão. Assim como, quando se decide movimentar para a direita os membros paralisados do corpo, estes, ao contrário, desviam à esquerda, assim também ocorre com a alma: os ímpetos dos acráticos vão em direções contrárias. Nos membros do corpo vemos o desvio; no tocante à alma, não o vemos. Contudo, não menos devemos considerar que também na alma há algo contrário à razão, contrapondo-se e resistindo a ela. Não importa como se distingue, mas manifestamente, esta parte participa da razão, como dissemos; pelo menos, a do homem que se controla obedece à razão - além disso, presumivelmente a do homem temperante e corajoso é ainda mais obediente, pois em tudo concorda com a razão" (EN I 13: 1102b15-29). Nesta passagem, a parte a qual se refere Aristóteles que é, por natureza, contrária à razão (para ton logou pephukos), que combate e puxa em sentido contrário à razão (ho machetai kai antiteinei tôi logôi) na alma dos controlados e descontrolados, é a parte desiderativa que se expressa por meio do apetite desregrado (no caso da acrasia no sentido próprio) e por meio do impulso desregrado (no caso da acrasia por homonímia). Ademais, o filósofo cita a seguir que, no caso do controlado, é evidente que este elemento participa da razão, ou seja, o apetite; e mais evidente ainda é no caso do temperante e do corajoso, pois, respectivamente o apetite e o impulso são mais obedientes e em tudo concordam com a razão.

142 Uma primeira versão deste texto foi publicada com o título Razão e desejo: uma comunicação persuasiva em Aristóteles, Anais de Filosofia Clássica, v. 9, n. 18, p. 1-19, 2015. 
de guerra interna entre pensar que algo é melhor, mas desejar fazer o seu contrário. É exatamente por isso que todos nós, segundo Aristóteles, devemos educar o desejo a desejar aquilo que pensamos ser melhor. O problema reside em saber como o pensamento ou a razão (logos) se comunica com esta parte de nós não racional que, muitas vezes, é avessa aos ditames da razão: o desejo (orexis).

Falar sobre a comunicação entre a razão e o desejo não é algo tão evidente à primeira vista. A dificuldade está na compreensão do próprio termo comunicação, pois compreender que a razão seja naturalmente uma capacidade propositiva não é difícil, mas, se estamos falando de comunicação, então se pressupõe que a outra parte, o desejo, ou diz algo, ou ao menos compreende o que foi dito, pois que certamente se comunica com a razão de alguma maneira. O ponto é que, para Aristóteles, o desejo não é uma faculdade naturalmente capaz de emitir enunciados. Todavia, no caso dos homens, ela é capaz de ouvir e falar a mesma voz que a razão, quando já fora habituada para tanto. Do contrário, o desejo parece assumir uma voz discordante da razão. O que não é evidente é saber a origem desta voz discordante. Ao que parece, a voz concordante nada mais é do que uma repetição uníssona do que diz a razão, todavia, discordar da razão significa não ouvi-la e, além disso, dizer algo contrário ao que ela diz. Se o caso da concordância uníssona é próprio da alma harmônica do virtuoso, o caso da discordância revela propriamente o conflito moral, como veremos. Assim, a comunicação parece ocorrer na medida em que a razão procura persuadir o desejo a seguir o que ela pensa ser o melhor, e o desejo, por sua vez, ora é persuadido e concorda, ora não é persuadido e discorda da própria razão.

\section{II}

A comunicação entre razão e desejo parece ser perfeita quando falamos de escolha deliberada, pois esta é o "intelecto desiderativo ou o desejo pensante", como define o filósofo em EN VI 2 (1139b6-7), ou seja, há uma perfeita comunhão entre desejar e raciocinar no ato de escolher, afinal a escolha é um desejo oriundo da escolha deliberada ou um "desejo deliberativo", que incide sobre o último meio, princípio este da ação deliberada. Assim, a enigmática frase lançada por Aristóteles parece ser mais clara do que se costuma admitir: "a escolha deliberada será, então, o desejo deliberado do que está em nosso poder, pois decidindo em função de ter deliberado, desejamos conforme à deliberação" (EN III 5, 1113a10-12). O desejo conforme a deliberação é o desejo deliberado, portanto, a escolha deliberada (prohairesis). A frase expõe de modo sucinto a definição de escolha deliberada 
e a explica em seguida. Não há qualquer referência aqui aos três tipos de desejo que incidem sobre o fim (querer, apetite e impulso). A razão, diante de um fim desejado por um dos três tipos de desejo, investiga os melhores meios para realizá-lo e avalia moralmente a ação a ser realizada. Esta capacidade de pesar razões, investigar os meios e ainda suscitar na alma um desejo por determinada ação, gerando-se assim uma decisão ou escolha, é chamada por Aristóteles de deliberação. Pois bem, a deliberação é, por excelência, um ato da razão prática, o prudente é aquele que bem delibera ${ }^{143}$ e a prudência é assimilada à boa deliberação. ${ }^{144}$ Esta operação racional, a deliberação, certamente atua no interior da alma não racional como que engendrando nela um desejo por realizar o que fora deliberado. Há, aqui, uma razão capaz de desejar ou um desejo capaz de pensar. Pode-se dizer que, aqui, não há propriamente uma comunicação entre dois elementos independentes, mas um monólogo. ${ }^{145}$ A razão delibera e o desejo segue. Aqui, de fato, estamos bem próximos do moderno conceito de vontade. A diferença é o objeto deste desejo. O meio e não o fim é objeto do desejo deliberado.

Agora, quando o nosso alvo é o desejo pelo fim, o rumo muda, as águas começam a ficar agitadas e turvas e a razão não consegue mais navegar com tanta facilidade. A barreira se impõe com nitidez e Aristóteles se posiciona assim: a parte desiderativa é não racional, mas capaz de participar (metechein) da razão. A razão, no âmbito dos desejos pelo fim, terá que se esforçar mais para se mover no interior do querer (boulêsis), do apetite (epithumia) e do impulso (thumos). A persuasão, neste momento, será uma arma indispensável. Aqui, a comunicação persuasiva entre razão e desejo efetivamente começa.

\section{III}

Aristóteles afirma, em Ética Nicomaqueia I 13, que a parte não racional do virtuoso é mais capaz de ouvir (eukoôteron) a razão que a do controlado (enkrates); e sobre todas as coisas, ela tem a mesma (homo) voz (phônê) que a razão

143 Cf. EN VI 8.

144 Cf. EN VI 10.

145 Enquanto querer, impulso e apetite são engendrados na parte não racional desiderativa, a escolha parece ser engendrada em uma região híbrida da alma entre a razão e o desejo, isto é, ela é engendrada por uma razão capaz de desejar e isto é evidente a partir da seguinte passagem: "Querer, impulso e apetite são todos desejos, já a escolha é comum ao pensamento (dianoia) e ao desejo (orexis) (De Motu 6, 700b23-24). 
(1102b27-28). Diante do que foi dito, a pergunta inicial que devemos fazer é a seguinte: o que significa dizer que a parte não racional tem a mesma voz que a racional? Isso significa que ela tem a mesma estrutura linguística que a razão? Seria o desejo uma capacidade propositiva? O filósofo nos diz que a parte não racional é capaz de ouvir a razão e até mesmo ter a mesma voz que a razão, como no caso do virtuoso, em que desejo e razão falam uníssonos; todavia, desta afirmação não poderíamos inferir que o desejo seja ou possa se tornar uma capacidade propositiva. Dizer que o desejo é capaz de formular e emitir proposições é dizer que ele é essencialmente racional, e isso certamente provocaria a assimilação da faculdade desiderativa à intelectiva. Aristóteles, por sua vez, é claro ao dizer que o intelecto é essencialmente racional, e que, portanto, ele é a única faculdade capaz de articular sons não significativos de modo a compor sons significativos, isto é, nomes e verbos e, portanto, proposições e discursos ${ }^{146}$; enquanto o desejo é racional apenas por participação e não em si mesmo, ou seja, ele capaz de ouvir e repetir as proposições formuladas pela razão, sem ser, ele mesmo, capaz de criá-las.

Certamente, o desejo é um movimento ou atividade da alma não racional que pode participar da razão, o que é evidente pelas límpidas palavras do filósofo estagirita ao comparar o desejo humano com a faculdade nutritiva: "uma outra natureza da alma também se mostra ser não-racional, participando, porém, em certa medida, da razão" (1102b13-14). A excelência do desejo, por sua vez, se traduz pela sua máxima concordância com a razão, como ocorre no caso do virtuoso (1102b25-29). Nas palavras de Jonathan Lear: "a excelência desta parte da alma não racional consiste em comunicar - ouvir e falar com a razão"147. E, como conclui Lear, o desejo deve exercer bem sua atividade comunicativa, pois a virtude ética nada mais é do que o bom exercício desta atividade comunicativa do desejo.

Se o desejo virtuoso é capaz de falar a mesma voz da razão é porque ele escuta, é persuadido, obedece e, por fim, segue o que diz a razão. A obediência do desejo em relação à razão é fruto desta capacidade de escutá-la bem e segui-la. E escutá-la bem é o mesmo que ser persuadido por ela. A razão, por sua vez, exerce plenamente sua função prática quando não apenas determina os bons meios,

146 Cf. De Int., 2, 16a19-29.

147 LEAR, 2014. 
mas também ou, sobretudo, quando persuade o desejo a desejar certo fim. Se a razão é capaz de persuadir o desejo, então o desejo, por sua vez, deve ser capaz de ser deixar persuadir. Ora, quando Aristóteles afirma explicitamente que o desejo pode ser persuadido pela razão, ele está pressupondo que desejar é distinto de sentir calor, dor, ou fome, pois não faz sentido tentar persuadir alguém a não sentir essas coisas, ${ }^{148}$ mas faz toda a diferença em termos educacionais tentar persuadir alguém (ou a si mesmo) a desejar ou não desejar certas coisas, ou seja, enquanto algumas sensações, como as mencionadas, não estão sob o nosso poder, o desejo está, em alguma medida, sob o nosso poder e esta medida é dada justamente pelo poder de persuasão da razão sobre o desejo. Com efeito, a persuasão (peithô) pressupõe a atuação da razão (logos) e, por persuasão, acreditamos (pistis) em algo, e por acreditarmos, temos certa opinião (doxa), e se temos certa opinião sobre o que é bom ou ruim, desejamos e agimos nesta ou naquela direção, como nos ensina Aristóteles em seu De Anima III, 3 (428a23). Isso significa que a persuasão exercida pela razão é fundamental para o direcionamento e, portanto, educação de nossos desejos e ações.

Agora, que tipo de persuasão seria essa se não há um par de falantes, mas um que fala - a razão - e outro que ouve - o desejo? O desejo é como a audiência de uma razão que lhe elogia, censura, exorta e, assim, o direciona para onde ela pensa ser melhor. Como diz o filósofo: "a advertência e toda censura e exortação indicam que a parte não racional é persuadida pela razão” (EN I 13, 1102b34). Trata-se, em alguma medida, do que poderíamos chamar de diálogo consigo mesmo. Certamente, a obediência ou concordância do desejo com a razão se segue não de uma imposição autoritária de ordens e deveres, mas de um trabalho de convencimento. Neste sentido, a interpretação de Cooper ${ }^{149}$ parece ser mais plausível do que a de Grönroos, ${ }^{150}$ pois, enquanto o primeiro enfatiza a capacidade de entender que possui o desejo por participar da razão, capacidade esta certamente limitada, como a de uma criança que ouve os conselhos ou elogios e censuras de um adulto, o segundo discorda de Cooper ao dizer que a parte não racional não compreende os argumentos ou considerações, mas simplesmente obedece à razão por autoridade.

148 Cf. EN III, 5, 1113b22-29.

149 COOPER, 1999, p. 91.

150 GRÖNROOS, 2007, p. 254. 
Conforme defende Cooper, este entendimento do desejo é limitado. Aristóteles se refere ao tipo de razão ou discurso que persuade em uma frase bastante curta: "a parte apetitiva e, em geral, desiderativa participa de certo modo da razão, na medida em que ouve (katêkoon) e obedece (peitharchikon), do mesmo modo como dizemos prestar atenção à razão (echein logon) do pai e dos amigos, mas não do modo como dizemos ter razão na matemática" (EN I 13, 1102b302). Essa razão, portanto, da qual participa o desejo é uma razão que diz respeito à ação e que faz uso de argumentos persuasivos, enquanto a razão na matemática diz respeito às abstrações matemáticas e faz uso de inferências demonstrativas. O desejo, por sua vez, é de certo modo (pôs) persuadido por esta razão prática e persuasiva, o que significa dizer que ele não é persuadido plenamente, como a razão de outra pessoa poderia ser, quando um adulto procura persuadir outro, mas como o desejo da mesma ou de outra pessoa poderia ser, como quando um adulto procura persuadir uma criança. $\mathrm{O}$ desejo, portanto, opera de modo análogo a uma criança e compreende como uma criança é capaz de compreender, portanto, não é capaz de reconstruir os argumentos que lhe foram apresentados e dizer sim ou não apresentando, por sua vez, outros argumentos por conta própria. O desejo compreende não de modo pleno, pois não possui plenamente a razão. A sua compreensão é tão limitada, parcial ou "intuitiva" como parece ser a de uma criança. Trata-se de uma persuasão que pressupõe o outro como possuindo uma racionalidade limitada, infantil, em desenvolvimento. Em termos gerais, esta parece ser a característica dada pelo Estagirita ao fenômeno da persuasão do desejo.

Ao contrário do que parece defender Grönroos, Aristóteles, a meu ver, nos diz explicitamente que o desejo precisa ser persuadido pela razão para que ele possa obedecê-la. Ele não será adestrado de modo a mecanicamente seguir a razão. Não se trata de uma obediência fanática ou cega, ${ }^{151}$ mas de uma obediência concedida. O desejo, portanto, será educado nos moldes aristotélicos e mesmo gregos de educação. Ou seja, a obediência, em termos de educação das emoções e desejos, se dá pela persuasão e não pela força de uma imposição legal ou moral. A força da persuasão está antes na sedução argumentativa e no acordo consentido do que na imposição. 
O que diferencia o virtuoso das demais figuras é que nele a sua parte não racional ouve a racional de modo a ser facilmente persuadida. Facilmente, isto é, sem conflito, como é o caso das figuras do controlado (encratês) e do descontrolado (acratico). O desejo, amparado por opiniões e imaginações contrárias à reta razão, pode ser veementemente resistente e mesmo intransigente, como ocorre no descontrole (acrasia). Neste caso, o desejo, mais particularmente o apetite deseducado, guia a ação sem empregar a persuasão, pois ele não poderia persuadir já que não possui por si mesmo o elemento racional. No caso do controlado, a razão guia a ação por meio da persuasão e agir por persuasão é agir não por força, mas voluntariamente. ${ }^{152}$ Nesses casos, a parte não racional não está tão permeável à parte racional de modo a se deixar persuadir pela razão. Em poucas palavras, enquanto o desejo é conforme à razão na alma do virtuoso, na alma em conflito, o desejo ora é conforme (como no autocontrole), ora é contrário (como no descontrole).

O conflito existe quando algum desejo segue não a reta razão, mas uma opinião contrária, como ocorre com o apetite no caso do descontrole. A opinião de que "todo doce é prazeroso" e a percepção de que "isto é doce", conjugada com o apetite excessivo pelo doce leva o descontrolado a comer o doce, contrariando a sua razão que lhe diz para evitar o doce. Neste caso descrito pelo filósofo, ${ }^{153}$ o apetite não ouve nem segue a razão, mas sim a opinião contrária à reta razão (orthos logos). Certamente, a opinião sobre o prazer do doce foi mais persuasiva do que o conhecimento de que isto lhe faria mal. No caso do controlado, por outro lado, a reta razão é mais persuasiva do que a opinião contrária. Isso porque o seu apetite não é forte o suficiente para lhe arrastar na direção contrária, o que significa dizer que, mesmo tendo em sua alma uma opinião contrária conjugada com um apetite, o controlado não cede. A opinião não é ela mesma

152 Como diz o filósofo, "por um lado, a persuasão é oposta da força e da necessidade, e o controlado (encratês) é conduzido por aquilo que ele foi persuadido, e procede não por força, mas voluntariamente. O apetite, por outro lado, não conduz tendo persuadido, pois não participa da razão" (EE II $8,1224 a 38-b 3)$. Devemos acrescentar que, quando deseducado, o apetite é resistente à participação da reta razão em seu interior. Neste sentido, o controlado se diferencia do obstinado, pois ele "não se altera por causa da emoção e do apetite, de modo que ele é mais facilmente persuadido (eupeistos) quando for a ocasião, mas os obstinados não se atêm à razão, de modo que eles são atraídos pelo apetite e muitos cedem aos prazeres" (EN VII, 9, 1151b8-12). Sobre a diferença entre o uso da força e o uso da persuasão, ver também Política V, 4, 1304b16.

153 Cf. EN VII, 3. 
capaz de mobilizar o indivíduo, mas o desejo que lhe acompanha sim. O apetite excessivo e maléfico é efetivamente contrário à reta razão. A opinião é contrária na medida em que acompanha a atuação ou mobilização do apetite. Como diz Aristóteles: "a opinião não é contrária por si mesma (kath'autên), mas por concomitância (kata sumbebêkos), pois o apetite é contrário, mas não a opinião” (EN VII 3, 1147a2-3). A passagem não é de fácil compreensão, mas o que importa dizer sobre ela é que o apetite não é capaz de discordar da razão emitindo, por si mesmo, proposições contrárias. Ele é antes uma força contrária não racional que encontra voz em uma opinião concomitantemente contrária. Não se trata, portanto, de simplesmente fazer calar a opinião contrária, mas de educar o desejo contrário em termos de persuasão ${ }^{154}$ e habituação, pois ele é capaz de mobilizar o agente, não a opinião.

É evidente que o desejo não raciocina por si mesmo e indício disso é que o filósofo comumente usa uma linguagem metafórica para se referir ao desejo que diz algo ou raciocina. Por exemplo, ao dizer que a parte desiderativa é também racional, Aristóteles faz a seguinte ressalva em seguida: então também será preciso dizer que a parte racional é dupla: "uma propriamente e em si racional, a outra como capaz de ouvir em certa medida o pai” (EN I 13, 1103a3). Enquanto o intelecto é em si mesmo racional, o desejo é racional por participação, ou seja, na medida em que é capaz de ouvir a razão, como uma criança é capaz de ouvir ao pai. Sendo assim, dizer que o desejo tem voz não significa dizer que ele tenha logos ou se expresse por meio de proposições. As crianças e os animais têm voz, embora não sejam racionais de distinta maneira: enquanto a criança é privada de razão por certo período de tempo, pois naturalmente a tem em potência e tende a desenvolvê-la, os outros animais são absolutamente privados de razão, portanto não deixarão de ser irracionais. ${ }^{155}$

154 Como afirma Speight (2005, p. 222) sobre o poder de transformação e cura da persuasão: "A persuasão deve ter não apenas o senso de uma convicção a partir da qual alguém age voluntariamente, não forçosamente, mas também uma 'abertura para ser mudado' no sentido em que Aristóteles mencionou 'curabilidade"'. Isso significa, continua o autor, que a persuasão tem o poder de encorajar a criança a se mover na direção da ação adulta e o acrático e o controlado na direção da virtude. (SPEIGHT, 2005, p. 224)

155 Enquanto a voz (phônê) é a expressão de sons significativos, de sinais (sêmeion) que manifestam algo, o logos é a articulação de sons de modo a compor símbolos (sumbolon), isto é, nomes (onoma) e verbos (rêma) (De lnt. 2). A matéria (hulê) do logos, por sua vez, é a voz, pois a razão se exprime sobretudo por meio da voz (GA, V, 7, 786b21). Por exemplo, na História dos Animais, o filósofo usa phônê para os grunhidos do javali e de porcos no período de copulação, nascimento e desenvolvi- 
Ou seja, a nossa parte não racional não é originalmente propositiva, ao contrário da parte racional cuja expressão é o próprio logos. A expressão da parte não racional é a da phônê e não a do logos.

Também é metafórica a expressão que o filósofo usa ao dizer que o impulso, mal tendo ouvido a razão, como que raciocina (hôsper sullogisamenos) e manifesta-se imediatamente. No contexto em que se pretende provar que a acrasia por apetite é mais injusta e vergonha do que a por impulso, Aristóteles diz o seguinte:

O impulso, devido ao calor e à impetuosidade de sua natureza, embora ouça (akousas), não escuta a ordem (epitagma akousas), e se impulsiona (hormâi) para a vingança. Isso porque quando a razão (logos) ou a imaginação (phantasia) diz que um ultraje ou um desprezo foi recebido, o impulso, como que tendo raciocinado (hôsper sullogisamenos) que alguém desse tipo deve ser combatido, imediatamente se manifesta (EN VII 6, 1149a30-4).

O apetite deseducado, por sua vez, parece ser mais avesso à participação da razão do que o impulso deseducado que, ao menos em parte, ouve a razão: "o apetite, por outro lado, se a razão (logos) ou a sensação (aisthêsis) apenas diz que algo é prazeroso, ele se impulsiona para deleitá-lo. Portanto, o impulso como que ouve a razão (logos) de certo modo, mas o apetite não" (1149a34-6). Isso significa que, em termos gerais, é mais difícil educar e persuadir o apetite do que o impulso.

Do que foi dito, podemos concluir que o grau de comunicação entre o desejo e a razão varia de dois modos: conforme o tipo de desejo e conforme o tipo de disposição moral. Quanto ao primeiro item, o querer (boulêsis) é o desejo mais capaz de ouvir a razão, afinal ele é um desejo sobre o que pensamos ser bom. ${ }^{156}$ O impulso, por sua vez, é parcialmente capaz de ouvir a razão e o apetite é o mais avesso aos conselhos da razão. Quando educados em uma alma virtuosa,

mento de seus filhotes (578a32). Ele também utiliza este termo quando se refere à voz dos pássaros (593a3-14). Ademais, ele distingue a voz dos animais de outros sons que eles fazem, sons não articulados, como os barulhos dos peixes e o bater das asas dos pássaros (535b13-32). Para saber mais sobre a distinção entre phônê e logos, ver Labarrière, 1984.

156 O que fora explicado no item anterior: 1.9 Querer, impulso e apetite. Como diz o filósofo: "ninguém quer o que não pensa ser bom" (EN V 9, 1136b8). Na Retórica I 10, diz que "o querer é um desejo pelo bem, pois ninguém quer algo senão quando pensa (oiêthêi) ser bom, enquanto a cólera e o apetite são desejos irracionais" (1369a1-5). Cf. também DA III 10: 433a24. 
a comunicação dos três tipos com a razão é excelente. Quando deseducados em uma alma viciosa, nenhum desejo é capaz de ouvir bons conselhos e o apetite governa aquele que é antes escravo de seu próprio desejo. No caso em que nenhuma participação é possível da razão no desejo e o desejo é surdo aos conselhos da razão, a comunicação inexiste; há como uma música de uma nota só: o desejo busca o prazer e a razão delibera os meios mais eficazes. Já na alma dos conflituosos, os controlados e descontrolados, o apetite não ouve a razão de modo algum e o impulso a ouve em parte. O querer, por sua vez, continua obedientemente seguindo o que a razão diz, embora não tenha força suficiente para vencer o apetite no caso do descontrolado e, no caso do controlado, consiga vencer a certo custo. Parece, então, que a disposição virtuosa é a expressão da excelência na comunicação entre o desejo e a razão, o melhor diálogo interno que poderia existir, a interação e integração mais harmoniosa da parte não racional da alma com a racional.

Como vimos, a parte desiderativa da alma é não racional na medida em que não possui a capacidade de raciocinar por si mesma e é racional na medida em que possui a capacidade de participar da razão, isto é, de ouvir bem e falar a mesma voz que a razão. Parece ser evidente que o desejo participa da razão na medida em que é capaz de se comunicar com ela, mas não é suficiente afirmar que há uma participação de tal tipo, é preciso dizer como exatamente se dá essa participação ou comunicação entre a razão e o desejo.

\section{IV}

Aristóteles oferece um modelo que evidencia a relação de participação entre razão e desejo. Como vimos, o desejo participa da razão como se estivesse ouvindo (katêkoon) e sendo persuadido ou obedecendo (peitharchikon) ${ }^{157}$ a um pai e aos amigos, ou seja, como uma criança que ouve bem e é persuadida pelas ordens e conselhos do pai ou de um amigo. Como disse, não se trata de um logos matemático, um logos que demonstra a verdade de objetos eternos e imutáveis, mas de um logos sobre o que deve ou não ser feito, um logos que persuade sobre a melhor ação a ser realizada, e que, portanto, seduz o desejo a lhe seguir. O desejo, por sua vez, é obediente na medida em que é persuadido e não por força ou 
coerção. De todo modo, o desejo nunca terá a autonomia racional que o intelecto possui. Ele será sempre uma criança que ora obedece, ora desobedece.

$\mathrm{Na}$ análise da temperança, Aristóteles também compara o desejo, no caso o apetite, com a criança e a razão com o seu tutor:

Os apetites devem ser moderados e poucos, e nunca se oporem à razão (logos), - isto é o que chamamos de ser bem obediente (eupeithes) e comedido -, a parte apetitiva deve ser conforme a razão (kata ton logon), assim como uma criança deve viver em obediência ao seu tutor. Portanto, no temperante, a parte apetitiva deve estar em harmonia com a razão (to epithumêtikon sumphônein tôi logôi); pois ambos, temperança e razão têm em mira o belo; e o temperante tem apetite com o que se deve, como e quando se deve, assim como ordena a razão (tattei ho logos)" (EN III 12: 1119b11-18).

É preciso notar que a obediência é sempre fruto da persuasão, sendo obediente aquele que literalmente foi bem (eu) persuadido (peithes). No caso do temperante (sôphrôn), a parte apetitiva está em harmonia e fala a mesma voz (sumphoneîn) que a razão. O temperante é aquele que persegue os prazeres devidos e assim o faz segundo a reta razão (hos ho orthos logos). ${ }^{158}$ Assim, a excelência ou virtude do desejo será a de ouvir bem, repetir as palavras da razão e lhe ser obediente. A educação lhe fará obediente por ter sido habituado a ouvir e seguir a razão.

A relação que a razão pode estabelecer com o desejo não é de mando a ser seguido direta e imediatamente. $\mathrm{O}$ desejo parece ser mais resistente do que gostaria a nossa crença moderna no poder quase ilimitado da racionalidade. Em contrapartida, a concepção aristotélica de conflito moral torna patente o limite da razão no âmbito prático. Há conflito quando há um desejo conforme e outro contrário à razão. Por isso, a razão não estaria em uma situação de livre acesso ao desejo, tampouco poderia manipulá-lo ao seu bel prazer. É preciso um esforço argumentativo que persuada, seduza e conduza o desejo. E isso deve ocorrer não uma ou duas vezes, mas diversas vezes até que se forme certo hábito, ou seja, até que repetidas ações ocorram e certa disposição de desejar o que é de fato bom se engendre em nós como uma segunda natureza. Uma vez alcançado o estágio firme e inabalável da disposição moral virtuosa, o desejo é mais 
facilmente conduzido pela razão. Chegar a esse estágio, bem sabemos, não é obra de um dia, mas de muitos dias, de muitas ações a serem repetidas continuamente. Repetição esta que não é meramente mecânica ou irrefletida, mas que envolve persuasão e, portanto, reflexão sobre o que se está fazendo. A habituação para o bem agir implica um trabalho contínuo de convencimento do desejo a desejar o bem em vista dele mesmo, convencimento este que se fez por meio das boas razões para se agir assim e não de outro modo. ${ }^{159}$ Afinal, não basta plantar uma semente, é preciso cultivar constantemente o jardim para que ela floresça e permaneça firme e forte diante das intempéries e vicissitudes da vida. Vale, então, para a maioria, a seguinte fórmula: como a terra que deve ser cultivada para receber a semente, o desejo deve ser cultivado para ouvir a razão. ${ }^{160}$

Como podemos perceber, o próprio filósofo, embora tenha explicitado que a razão se comunica com o desejo persuadindo-o e o desejo participa da razão sendo por ela persuadido, ainda assim, não nos fornece uma exposição detalhada e aprofundada sobre como ocorre exatamente esta persuasão. E perguntar sobre como ocorre a participação do desejo na razão nada mais é do que perguntar sobre o tipo de persuasão que está em jogo. Assim, recorrerei à Retórica de Aristóteles tendo em mente que, por esta via, poderei explicitar o tipo de persuasão a ser utilizado pela razão diante do desejo pelo fim. Esta razão trabalhará como um orador na produção de argumentos para convencer o desejo sobre o que é bom e sobre o modo moderado de se desejar o bem em vista dele mesmo. Vejamos, por fim, que este logos que aconselha, ordena e persuade é essencialmente um logos retórico.

159 Neste ponto, mais uma vez discordamos de Grönroos que supõe que o desejo não pode ser convencido pela razão e que a sua educação seria feita em termos de habituação, excluindo, por sua vez, do hábito e da educação do desejo qualquer elemento cognitivo ou persuasivo. Distinguindo em termos absolutos experiência e raciocínio, Grönroos (2007, p. 264) afirma literalmente que a habituação é "o processo ou mecanismo pelo qual a parte não-racional é posta em acordo com a razão, sem pressupor qualquer quantidade de raciocínio na parte não-racional da alma".

160 Nas palavras do filósofo: "Com efeito, o argumento (logos) e o ensinamento (didaxe) certamente não têm poder sobre todos os homens, mas antes a alma de quem escuta deve ter sido cultivada previamente (prodieirgasthai) por meio de hábitos em regozijar (xairein) e odiar o que for belo, como a terra que deve ser nutrida para receber a semente. Isso porque aquele que vive segundo os afetos (pathos), não escutará nem entenderá o argumento que tenta dissuadi-lo; e, se assim for, como convencê-lo a mudar? Em geral, o afeto parece não ser dominado (hupeikein) pela razão, mas por força. É preciso, portanto, que o caráter possua de antemão certa familiaridade com a virtude, tendo amor pelo que belo (kalon) e ódio pelo que é vil” (ENX 9: 1179b24-31). 


\section{V}

A comunicação estabelecida entre a razão e o desejo não poderia ser dialética, tampouco seria uma espécie de demonstração científica. Não é dialética, porque não pressupõe uma interlocução com o desejo. O desejo não é capaz de dialogar respondendo ou fazendo perguntas. Tampouco a razão estaria empenhada em verificar possíveis contradições em nossos desejos, nem almejaria um desejo capaz de ser convencido das verdades filosóficas. A razão também não poderia proceder por demonstração científica, cujo objetivo é demonstrar por meio de verdades necessárias e imutáveis certo saber teórico. A razão, neste caso, tem que ser prática, no sentido de versar sobre as ações. Esta razão prática parece, por exclusão dos outros dois tipos de argumentação, proceder conforme a argumentação retórica, pois não se trata de verificar verdades ou falsidades em nossos desejos, tampouco de direcioná-lo para o âmbito científico ou filosófico. Trata-se de educá-lo a ser melhor do ponto de vista prático, portanto, de persuadi-lo a desejar o bem em vista dele mesmo, bem este apreendido pela reta razão. O logos envolvido nesta comunicação é necessariamente um logos retórico.

A razão é como um orador que fala sobre uma ação para um ouvinte: o desejo. E a finalidade do discurso é persuadir o ouvinte. Eis os três elementos básicos que compõem todo discurso retórico: aquele que fala, aquilo de que se fala e aquele que ouve ${ }^{161}$. O desejo ouvinte seria antes um espectador do que um juiz, pois não seria capaz de emitir julgamentos. A razão, por sua vez,poderia aconselhar o desejo sobre o que é conveniente (sumpheron) e bom ${ }^{162}$ ou prejudicial (blaberon) tendo em vista o presente ou o futuro, ${ }^{163}$ e assim argumentar de modo a persuadi-lo ou dissuadi-lo, atuando semelhante a um orador de assembleia que faz uso do discurso deliberativo. Também poderia a razão atuar como um juiz diante de nossos desejos, como um orador em um tribunal que faz uso do discurso judicial, julgando se o que foi desejado ou se o que estamos desejando é justo ou injusto e acusar se for injusto e defender se for justo. Também poderíamos pensar em uma razão que atuaria como um orador que elogia ou censura um desejo no que há nele de belo (kalon) ou de vergonhoso (aischron),
\end{abstract}

161 Cf. Ret. I3, 1358 b1.

162 Sobre o bem enquanto objeto do discurso deliberativo, ver Ret. I 6, 1362b15-2, e, sobre o belo, ver Ret. I 9, 1366a34-b1.

163 Cf. Ret. I 6, 1362a15. 
como um orador que usa do discurso epidítico. ${ }^{164}$ É preciso deixar claro que faço aqui apenas uma analogia entre os gêneros de discurso retórico e os modos pelos quais a razão poderia persuadir o desejo.

Assim, por analogia ao uso do discurso persuasivo do orador, pretendo deixar mais inteligível esta comunicação de viés persuasivo da razão em relação ao desejo apenas no que nos é suficiente para a presente investigação. Também é manifesta esta relação em nossa vida quando realizamos uma espécie de diálogo com nós mesmos. Ora repreendemos, ora elogiamos certo desejo que surge em nossa alma. Ou mesmo outra pessoa repreende ou elogia certo desejo que temos. Certamente, o elogio (epainos) e a censura (psogos) são meios que o próprio filósofo explicitamente diz que a razão usa para persuadir o desejo, ${ }^{165}$ no que há nele de belo ou de vergonhoso, e assim ela o faz seja em um solilóquio interior, seja quando o outro dialoga conosco. E isso pode ocorrer somente quando exprimimos nosso desejo em palavras ou ações.

Bem sabemos que tanto as Éticas como a Retórica tratam do elogio e da censura no que se refere, sobretudo, às ações. ${ }^{166}$ Ora, se agimos livremente, voluntaria ou deliberadamente, agimos motivados por um desejo. Assim, elogiar ou censurar uma ação significa também elogiar ou censurar a intenção que a motivou. Ao se perguntar se a felicidade é objeto de elogio ou de honra, em EN I 12, Aristóteles nos diz que nós não elogiamos a felicidade e sim as ações que nos conduzem e constituem a própria vida feliz, pois "todo objeto de elogio é elogiado por ter certa qualidade e por se referir a algo" (1101b13). Pois bem, elogiamos certas ações por serem virtuosas e por serem relativas ao bem viver, fim último de todas as ações. E assim o filósofo conclui o assunto dizendo que "o elogio diz respeito à virtude, pois por ela fazemos ações belas" (1101b32); a felicidade, por sua vez, é objeto de honra e não de elogio. Aristóteles é conciso no que diz respeito à temática do elogio, pois será na Retórica que tratará do assunto em maior detalhe, como ele mesmo afirma. ${ }^{167} \mathrm{Na}$ Retórica, o elogio é definido como "um discurso (logos) que exibe a grandeza de uma virtude, portanto, é necessário mostrar que as ações são virtuosas” (Ret. I 9, 1367b28-29). Disso

164 Cf. Ret. II 22, 1396a26-31.

165 Cf. ENI 13, 1102 b35.

166 Cf. Ret. I 9, $1367 b 28$.

167 Cf. ENI 12, 1101 b36. 
podemos inferir que exibir a virtude de uma ação também significa exibir a virtude do desejo que a motivou ${ }^{168}$.

Ao que parece, é possível reconhecer um tipo de função racional que atua diretamente seja sobre a ação motivada por determinado desejo, seja sobre o próprio desejo, procurando educá-lo ao longo do processo de formação do caráter. No processo formativo, a razão que atua na educação dos desejos pode ser compreendida como uma racionalidade presente tanto nos conselhos, como nas censuras e elogios. Aliás, o elogio e o conselho são uma espécie comum (koinon eîdos) de discurso, pois a diferença entre o conselho (sumboulê) e o elogio (epainos) é uma diferença lexical ou de expressão (lexis). Trata-se de uma mudança na posição da expressão (lexei metatithenai), o que é bastante útil quando sabemos o que devemos fazer e como devemos ser. Assim, tendo tal sabedoria prática, podemos fazer a seguinte mudança nas expressões segundo o filósofo:

Por exemplo, 'é preciso não se orgulhar do que se obtém por causa da sorte (tuchên), mas apenas do que se obtém por causa de si mesmo'. Quando se expressa assim, tem-se a força de uma sugestão (hupothêkên), mas será um elogio se expresso desse modo: 'ele se orgulha não do que obtém por causa da sorte, mas do que obtém por causa dele mesmo' (Ret. I 9, 1368a4-8).

Como se vê, entre o conselho e o elogio, há apenas uma mudança na expressão. O conselho pode expressar o que deve ser feito de modo mais geral e indireto, enquanto o elogio comumente se refere diretamente àquele que realizou bem uma ação. Ademais, também poderíamos acrescentar, como bem notou Speight, ${ }^{169}$ que há uma diferença de direcionamento temporal: enquanto o conselho é usualmente prospectivo, pois aconselhamos sobre como se poderá agir no futuro (sendo a retórica deliberativa direcionada para o futuro), o elogio e a censura possuem antes um aspecto retrospectivo, pois incidem normalmente

168 Isso é válido somente se esta ação estiver sendo feita com vistas à virtude, porque alguém pode fazer uma ação virtuosa com vistas a um fim perverso. Se este for o caso, a ação não seria propriamente virtuosa, mas apenas similar, do mesmo modo seria o desejo que a motivou.

169 Ver Speight (2005, p. 213). O autor acrescenta mais adiante que, mesmo tendo o elogio e a censura, sobretudo, um aspecto retrospectivo, eles também podem atuar de modo prospectivo, pois um elogio diante de uma ação boa ou uma censura diante de uma má ação pode encorajar a busca pela realização da boa ação (SPEIGHT, 2005, p. 217). Sobre este ponto, Nussbaum (1983, p. 154) parece estar totalmente de acordo. 
sobre uma ação que está ocorrendo ou que ocorreu (sendo a retórica epidítica direcionada para o presente). De todo modo, ambos emulam a boa ação e assim persuadem o desejo a desejar o que se deve. Enfim, ambos são discursos pelos quais a razão persuade o desejo ao que é correto desejar. Portanto, a razão prática parece ser capaz de persuadir ao exercer uma função emulativa ou admoestadora, função esta análoga ao discurso epidítico.

Falamos, basicamente, do papel da censura e do elogio na educação moral que se exprime de modo análogo ao discurso epidítico. Falemos agora de uma racionalidade corretiva que se exprime similarmente ao discurso judicial. Em determinados momentos, escrutinando o nosso passado, atuamos como juízes de nós mesmos, ora nos acusando como expressão de autocensura e nos arrependendo por termos cedido a determinado desejo que motivou uma ação injusta, ora sendo acusados por outra pessoa e reconhecendo o erro ou nos defendendo ao dizer que não fora proposital ter cedido a certo desejo ou que não havia alternativa, e tantas outras justificativas. Ora podemos ser acusadores e réus de nós mesmos em momento de agudo conflito, quando oscilamos entre repreender ou simplesmente justificar determinado desejo. Diante de uma ação ou desejo, não é fácil julgar corretamente o erro e o acerto, pois tampouco é fácil definir o que é justo e injusto, e se foi justo ou não ter desejado isto ou aquilo. Na Retórica, Aristóteles entende que cometer injustiça é "causar dano voluntariamente em violação da lei” (I 10, 1368b7), e os motivos pelos quais se causa dano são, diz ele, "a maldade (kakia) e o descontrole (acrasia); pois se uma pessoa tem um ou mais vícios, naquilo em que são viciosas são também injustas” (1368b13-15). ${ }^{170}$ Logo, se a motivação da ação viciosa e injusta é um desejo vil e injusto, então acusar o erro moral de uma ação deste tipo é também acusar o desejo que a motivou. Comumente, o desejo que causa uma injustiça é o apetite e o que tem sede de justiça é o impulso e isso é evidente tanto na Retórica I 11, como na Ética Nicomaqueia VII 6, em que o filósofo defende que a acrasia por apetite é mais grave do que a acrasia por impulso, pois a primeira é própria daquele que comete uma injustiça e a segunda daquele que sofre uma injustiça, sendo o apetite o desejo que motiva

170 Aristóteles, em seguida, investiga as causas da ação injusta e estabelece que, "quando são autores das ações, fazem umas por hábito e outras por desejo, seja por desejo racional ou irracional. O querer é um desejo pelo bem, pois ninguém quer algo senão quando pensa (oiêthêi) ser bom, enquanto a cólera e o apetite são desejos irracionais" (1369a1-5). 
a ação injusta e o impulso, o desejo de vingança por ter sido injustiçado. Quanto à Retórica, temos o que se segue:

Agradável é tudo aquilo que se tem apetite (epithumia), pois o apetite é o desejo pelo prazeroso. Dos apetites, uns são irracionais e outros são racionais (meta logoû). Denomino irracionais aqueles que ocorrem sem consideração prévia (hupolambanein) e tais são aqueles denominados naturais (phusei), como os que subsistem por causa do corpo - por exemplo, o desejo por alimentos, a fome, a sede, e o apetite conforme cada espécie de alimento; também aqueles que se referem ao paladar, aos prazeres sexuais e em geral ao tato, ao olfato, à audição e à visão. Por outro lado, denomino racionais os apetites que procedem da persuasão (ek toû peisthênai), pois são muitas as coisas em que há apetite de contemplar e de possuir por se ter ouvido (akousantes) e ter sido persuadido (peisthentes) (1370a17-27).

Como se pode notar, não apenas nas Éticas, mas também na Retórica, Aristóteles afirma explicitamente que o desejo pode ouvir e ser persuadido, no caso, o apetite, desejo por excelência mais avesso à atuação da razão em seu interior. Mesmo sendo o menos permeável, certamente ele pode ser educado e aqui está posta a condição de possibilidade, a saber: ele pode ouvir e ser persuadido pela razão, tornando-se por isso mesmo um desejo com razão ou conforme a razão (meta logoû), portanto, um desejo educado.

Enquanto o uso dos exemplos é mais adequado ao discurso deliberativo, o uso de entimema é mais característico do discurso judicial, ${ }^{171}$ pois é preciso demonstrar se de fato uma ação injusta foi realizada ou não e se foi intencionalmente realizada. É claro que, além do recurso silogístico, a retórica judicial usa de outros meios persuasivos, como suscitar emoções e tornar manifesto o caráter digno de confiança do orador. Os meios persuasivos ou as provas técnicas e não técnicas não são objetos de nossa investigação. É suficiente sabermos que este tipo de discurso pode, por analogia, ser utilizado pela razão para convencer o desejo a desejar o que é justo. Do mesmo modo, persuadir-se de que o que se fez é injusto pode ser um bom início para não mais agir injustamente e, consequente e futuramente, passar a não desejar mais agir assim. 
Também podemos corrigir certa tendência desiderativa ou repetição de desejos similares por meio da mudança de hábito, o que implica autoconhecimento. Para tanto, é fundamental que o indivíduo saiba para quais desejos ele tende, quais hábitos engendram tais desejos e como é possível efetivamente mudar de hábito. Assim sendo, este modo de atuação da razão, que parece ser primordialmente avaliativo e controlador, se expressa pelo que chamamos de conhecimento de si e cura pelo contrário. ${ }^{172}$

Discorremos basicamente do papel da censura e do elogio que se exprime por meio do discurso epidítico, bem como do papel corretivo do discurso judicial. Tratemos agora da racionalidade avaliativa que se exprime analogamente por um discurso deliberativo. Que o discurso deliberativo é um gênero que, por excelência, diz respeito à ação e, mais especificamente, à ação que conduz para a felicidade, é evidente. ${ }^{173}$ Pois bem, o que não é evidente na ética aristotélica é que esse tipo de discurso também seja capaz de persuadir o desejo pelo fim, visto que a deliberação diz respeito somente aos meios. Explico-me: se o objeto da escolha deliberada são os meios e não os fins, então podemos afirmar que nós não escolhemos desejar este ou aquele fim, mas escolhemos realizar ou não este ou aquele fim desejado. Isso significa que o fim é escolhido apenas na medida em que escolhemos os meios para realizá-lo. Mais uma vez, não escolhemos aquilo que desejamos, mas se realizamos ou não isto que já desejamos realizar. Por exemplo, "queremos (boulometha) estar saudáveis, mas escolhemos deliberadamente (proairoumetha) que coisas nos tornarão saudáveis; queremos ser felizes e o declaramos, mas não é apropriado dizer que escolhemos deliberadamente ser felizes". (EN III, 2, 1111b27-29) Pois bem, deliberamos sobre realizar ou não certo desejo e como seria a melhor maneira de realizá-lo. Ao deliberarmos sobre como realizar certo fim desejado, também estamos deliberando se é correto ou não realizá-lo. Ao escolhermos realizar os meios, também estamos escolhendo realizar o fim para o qual os meios nos conduzem. Em suma, a deliberação não atua direta e imediatamente sobre o desejo, visto que não podemos

172 Ver seção “O hábito”. Nas breves palavras do filósofo dedicadas a esta questão: “Devemos ficar atentos aos erros aos quais somos mais propensos: alguns tendem para uns; outros, para outros. Isto torna-se conhecido pelo prazer e pela dor por que passamos. Devemos puxar a nós mesmos em direção ao ponto oposto, pois chegaremos ao meio termo afastando-nos tanto quanto possível do erro, como fazem os que endireitam a madeira empenada" (EN II 9: 1109b2-8).

173 Cf. Ret. I 5, 1360b4-6. 
escolher o que iremos desejar, mas se iremos realizar ou não o que já desejamos. É tese bem estabelecida na ética aristotélica que a constituição do fim desejado antecede à deliberação e, portanto, à escolha deliberada. Isso significa que ele não é fruto de uma escolha, mas, ao contrário, a escolha tem como causa o fim desejado; pois a escolha é um desejo deliberado pelos meios capazes de realizar certo fim. A escolha, portanto, é o desejo oriundo da investigação deliberativa, cujo objeto é um meio realizável aqui e agora em vista de um fim já dado. Quanto ao fim propriamente, a escolha não o constitui, mas apenas o aprova ou não.

A Retórica, por sua vez, colabora, a meu ver, com o esclarecimento sobre o discurso deliberativo cuja atuação avaliativa já fora designada pela Ética $\mathrm{Ni}$ comaqueia. A boa deliberação não deve ocorrer simplesmente para determinar os meios que nos levam ao fim desejado, pois determinar os meios já significa aprovar a realização do fim. Por isso, também deliberamos para nos convencer de que, por exemplo, desejar isto não é o melhor a se fazer, que o melhor seria desejar aquilo e assim procuramos persuadir o nosso desejo e nos controlar, embora haja tanto descontrole. Avaliar a qualidade moral do fim e, se for o caso de não aprová-lo, procurarmos nos controlar e frear o desejo: eis a função persuasiva do discurso deliberativo. $\mathrm{O}$ orador deliberativo tem como principal tarefa aconselhar (sumbouleuei) sobre o bem e o mal das coisas que podem vir a ocorrer, portanto, sobre a qualidade moral das ações e suas consequências ${ }^{174}$. Tendo em vista o futuro, portanto o bom direcionamento com relação ao que desejaremos e faremos, o uso de exemplos ${ }^{175}$ é bastante útil, pois "é examinando o passado que adivinhamos e julgamos o futuro” (Ret. I 9, 1368a30).

Diante de tudo o que foi explanado, gostaria de propor a seguinte inferência: enquanto o discurso deliberativo cujo objeto é o conveniente e o bem, incide, sobretudo, no querer, desejo pelo bem e por excelência mais obediente à razão, dando-lhe conselhos. O discurso judicial parece incidir, sobretudo, no apetite e no impulso, sendo o apetite mais próprio àquele que comete certa injustiça porque o injusto lhe parece prazeroso, e o impulso mais próprio àquele que sofre uma injustiça e tem sede de vingança, portanto justiça. A razão, em seu papel educativo, por um lado, irá acusar e repreender a ação injusta e o apetite que a causou, e, por outro lado, defender o impulso por justiça, desde que

174 Cf. Ret. I 4, 1359a30.

175 Há duas espécies de exemplos: os de fatos passados, como os testemunhos, e os inventados, como as fábulas. Para tanto, ver Ret. II 20. 
ele seja moderado. O discurso epidítico, por sua vez, parece incidir sobre os três tipos de desejos, pois todos são elogiados quando corretos (ao serem conforme a reta razão) e censurados quando incorretos (ao serem contrários à reta razão).

\section{VI}

Em linhas gerais, pretendi expor, neste texto, os modos pelos quais o desejo pode ser persuadido pela razão, portanto, as várias funções que a razão exerce ao se esforçar por persuadir o desejo, sendo elas (i) a função de emular ou admoestar por meio de elogios e censuras, portanto, analogamente ao discurso epidítico; (ii) a função corretiva que se exprime nas acusações e defesas semelhantemente ao discurso judicial; e (iii) a função avaliativa do discurso deliberativo, que se exprime nos conselhos. Admoestar, emular, exortar, censurar, elogiar, acusar, defender, avaliar, aconselhar, corrigir, controlar, ordenar, direcionar, enfim, assim atua a razão por meio do discurso com vista a persuadir o desejo. Esta trajetória de persuasão que se estende ao longo da vida pode ser descrita do seguinte modo: podemos admoestar a nós mesmos, elogiando ou censurando os próprios desejos, ou sermos elogiados ou censurados por outro; como também podemos avaliar o nosso desejo por aconselharmos a nós mesmos ou por termos ouvido determinado conselho, e assim decidirmos não realizar certo desejo ou realizá-lo de outro modo e em outro momento. Também podemos corrigir nosso desejo quando o mesmo é acusado de vil e injusto e, por mudança de hábito, mudarmos o nosso modus operandi de desejar.

Assim, podemos concluir que o desejo pelo fim é permeável ao discurso retórico da razão, na medida em que pode ouvi-la e até mesmo falar a mesma voz que a razão. Embora não tenha por si mesmo logos, certamente pode participar do logos, ouvindo-o e sendo persuadido por ele. Em verdade, a excelência moral do desejo depende da boa comunicação entre ele e a razão. Quanto melhor for tal comunicação, quanto mais participativo for o desejo na racionalidade, mais persuadido, mais educado, mais virtuoso ele será. Mesmo não tendo logos, a não ser por participação, o desejo pode, por maldade ou descontrole, não ouvir à reta razão e sim uma opinião contrária, e falar a mesma voz que tal opinião, impulsionando-nos ao erro moral. A educação moral, segundo Aristóteles, tem como principal finalidade educar os desejos e isso só é possível se a nossa reta razão conseguir efetivamente persuadir o nosso desejo a desejar o bem que ela, corretamente, apreendeu. 
Diante da busca central desta investigação, que visa determinar quais e como certas operações racionais atuam sobre o desejo no processo formativo do caráter, vimos que, ao menos duas delas são evidentes: a racionalidade dos outros que nos educam enquanto jovens, e a racionalidade que vamos aprendendo a usar para aperfeiçoar o próprio caráter. Vimos também que a ação e a persuasão são as vias pelas quais a razão pode atuar sobre o desejo, seja para criar ou para mudar hábitos adquiridos, seja convencê-lo a desejar o que fora determinado racionalmente como sendo bom.

Em outras palavras, a educação moral serve para que o desejo passe a ouvir e a ter prazer com o que a razão determina como sendo de fato um bem. Ficou claro que esta razão capaz de determinar o bem a ser desejado como fim da ação não poderia ser exterior ao agente, nem deliberativa. O desejo, uma vez educado, é capaz de ter como objeto o bem apreendido pela razão persuasiva. Sendo assim, podemos concluir que esta educação nada mais é do que uma preparação prévia necessária para que esta função racional constitua o fim da ação.

Apenas uma razão que esteja em harmonia com o desejo é capaz de atuar na constituição de seu objeto. Em outros termos, a razão só é capaz de participar do desejo se e somente se houver a educação do desejo. Aristóteles, como se sabe bem, não nomeia tal tipo de função racional, mas pressupõe que apenas a razão pode apreender o bem verdadeiro nas circunstâncias particulares e que o desejo educado deve tomá-lo como seu objeto. Isso porque o desejo não é capaz de determinar o que é bom, mas é por natureza capaz de apenas de perseguir o prazeroso, embora possa, por educação, se tornar capaz de perseguir aquilo que a razão apreende como de fato um bem.

A única indicação que o filósofo nos fornece é que o fim é visto pelo virtuoso e não escolhido deliberadamente por ele. Este parece ser um princípio adotado por Aristóteles, que não explica, mas apenas estabelece o pressuposto de que o virtuoso vê (horan) $)^{176} \mathrm{o}$ que deve ser feito. Interpreto que este pressuposto nada mais é do que a afirmação de que o desejo põe o fim que dita a reta razão em sua função persuasiva e não em sua função deliberativa, uma vez que o fim não é constituído por escolha deliberada.

176 O virtuoso vê (horan) o que é bom a ser feito: EN III 4 1113a34 e vê corretamente (horosin orthos): EN VI 14 1143b14. 
Quanto ao pressuposto, podemos esclarecê-lo se considerarmos que as circunstâncias que envolvem a ação não podem ser estabelecidas a priori, mas tão somente no momento da ação. Este parece ser claramente o motivo pelo qual Aristóteles afirma que a discriminação do que deve ser feito reside na percepção. ${ }^{177}$ Com efeito, é difícil determinar o meio termo, assim como é igualmente difícil censurar aquele que se distancia do meio termo, visto que "não é fácil determinar pela razão até que ponto e em quanto ele é censurável, pois tampouco o é algum objeto sensível: tais objetos ocorrem nos casos particulares e a discriminação é matéria de sensação (têi aisthêsei hê krisis)”. (EN II 9: 1109b21-3) Dizer que a discriminação do meio termo é matéria de sensação se justifica pelo fato de que o fim é uma circunstância particular determinável conforme a ocasião (kata tonkairon), ${ }^{178}$ portanto, conforme a particularidade que exige a situação presente. Por isso, conceber um fim significa determinar racionalmente o que é preciso ser feito aqui e agora diante das circunstâncias que se apresentam aos nossos sentidos; seja em vista de sobreviver apenas, como no caso dos animais, seja em vista de bem viver, como no caso dos homens.

O desejo é capaz de imaginar como sendo bom qualquer objeto que assim lhe apareça como tal; porém, só é capaz de pôr o fim correto se o seu objeto for aquilo que ajuíza a razão como sendo um bem verdadeiro. Enquanto o desejo não educado se guia pelo prazeroso, o já educado é capaz de ter prazer pelo que é racionalmente apreendido como um bem. O virtuoso é paradigmático para compreendermos o que foi dito, pois ele se encontra numa harmonia tal que o que a razão vê como sendo o melhor, o desejo deseja. Em suma, a educação moral parece ser condição simultânea da apreensão racional verdadeira do bem e do desejo que o toma como objeto, ou seja, o virtuoso vê e imediatamente deseja o que deve ser feito, pois seu desejo é facilmente persuadido pela razão. E assim o faz porque está previamente disposto a fazê-lo. O virtuoso não poderia ver o que deve ser feito e não desejá-lo. Este seria o caso do vicioso que, mesmo sabendo o que deve ser feito, deseja e faz o

177 Cf. EN IV 5: $1126 b 5$ e II 9: 1109b23. Por isso, acertadamente, Burnyeat (2010, p. 159) diz que "o nobre e o justo não admitem, segundo Aristóteles, formulações precisas em regras ou preceitos tradicionais (cf. I 3 1094b14-16; II 2 1104a3-10; V 10 1137b13-32; IX 2 1165a12-14). É necessária uma percepção educada, uma capacidade que vá além da aplicação de regras gerais, para dizer o que requer a prática das virtudes em circunstâncias específicas".

178 Cf. EN III 1: 1110a14 e 1111a19. 
contrário. Também não poderia o virtuoso ver o que deve ser feito, desejar e não agir conforme o que deve ser feito. Este é o caso do descontrolado, que é impulsionado antes pelo desejo contrário do que conforme a razão. Também não poderia o virtuoso ver e agir corretamente, sem desejar o que é bom em vista dele mesmo. Este, como sabemos, é o caso do controlado, que age conforme a razão, mas sem desejar o fim virtuoso por si mesmo.

Em suma, não pretendíamos, com o presente texto, demonstrar como ocorre em detalhe o processo de formação da criança até a fase adulta, ${ }^{179}$ mas apenas examinar se e como a razão pode atuar sobre o desejo, ou seja, como a comunicação persuasiva se efetiva. Para tanto, bastou-nos distinguir dois momentos da formação: um anterior e outro posterior à educação do desejo. Ou seja, ao mesmo tempo em que a criança está sendo orientada pela autoridade exterior, ela vai gradualmente aprendendo a discriminar o certo do errado e assim ela vai criando uma espécie de sensibilidade moral e se tornando capaz de tomar decisões por conta própria. Por um lado, a criança está sendo disciplinada e se autodisciplinando ao praticar e manter, por hábito, o que aprendeu. Por outro, as leis, assim como todo elogio e censura, estiveram e sempre estarão presentes para regularem o comportamento dos adultos por toda a vida. ${ }^{180}$

A educação moral é justamente a realização da passagem entre o agir virtuosamente sem ser virtuoso ao agir virtuosamente sendo virtuoso; da passagem do agir por autoridade exterior ao agir em vista do fim virtuoso desejado por ele mesmo; do desejo pelo prazeroso ao desejo de ser virtuoso e feliz para, por fim, atingir o desejo virtuoso, isto é, aquele que deseja o bem em vista dele mesmo. Isso significa realizar plenamente o que se é, pois uma vez vindo a ser bom, o homem realiza plenamente sua função própria, a saber: viver conforme a sua racionalidade. Com efeito, a aquisição de virtude é condição necessária para a realização da racionalidade prática em seu grau máximo de autonomia, de modo que ela seja capaz de ver o fim correto e persuadir o desejo a buscá-lo, bem como deliberar sobre os melhores meios para realizá-lo. ${ }^{181}$ Por isso, podemos dizer, sem hesitação, que a finalidade da educação moral é tornar prática a função persuasiva da razão, de modo que ela possa atuar sobre o desejo e ser

179 Para tanto, ver Sherman (1989, p. 157-199), cap. 5: "The habituation of Character".

180 Cf. EN X 9: 1180a1 e ss.

181 Como diz o filósofo: "este olho não adquire sua qualidade sem a virtude, como falamos" (EN VI 12: 1144a29-33). Ver também 1144b10-13 e b30-33. 
efetivamente causa coadjuvante na constituição do fim. A educação, como vimos, torna a razão prática correta, participativa, orientadora do desejo e este, por sua vez, torna-se mais capaz de ser conforme a razão.

A razão, uma vez vindo a ser reta, é capaz de discriminar corretamente as circunstâncias particulares de modo a encontrar o meio termo a ser desejado e almejado na ação. Esta retitude discriminativa, esta justeza e agudeza na razão apenas podem ocorrer naquele que está previamente preparado em termos afetivos, isto é, que seja afetivamente capaz de ver o melhor. Ou seja, o bom uso da razão está condicionado ao bem-estar afetivo. Trata-se, antes, de ser afetivamente capaz de ajuizar corretamente o que é bom do que de ser racional o suficiente para dominar os afetos. Discernir as circunstâncias particulares e ver o meio termo a ser desejado é, sem dúvida, uma apreensão racional sustentada por certa disposição em assim apreender. Ou seja, para ver o que é bom a ser feito é preciso querer ver desse modo. É preciso ter um caráter virtuoso para ver por si próprio o melhor. Por isso, o caráter se expressa não apenas no que o sujeito faz, mas também no que ele vê que deve fazer e deseja isto mesmo.

Por exemplo, trata-se de ser colérico o suficiente para saber bem se vingar ou se defender de uma ofensa; de ser moderado o suficiente, isto é, na justa medida, para desfrutar, no momento oportuno, de prazeres saudáveis; de ser bem disposto a enfrentar a dor de modo a ver o que é corajoso a ser feito; trata-se de perceber que uma dada situação exige uma ação generosa e de desejar realizá-la, mas tal sensibilidade moral depende de já haver uma disposição generosa para tanto; e assim por diante com relação às outras virtudes particulares e suas respectivas emoções e desejos. As coisas assim nos aparecem conforme a disposição que temos em percebê-las e o estado afetivo em que nos encontramos. Isso que foi dito não é senão um desmembramento congruente à tese aristotélica de que todo bem é também bem aparente (phainomenon agathon), ou seja, todo bem real precisa ser apreendido verdadeiramente como tal e esta apreensão depende de uma disposição de bem desejar, isto é, de desejar retamente.

Daí podemos inferir que mais do que o conhecimento do que é certo, são os afetos que determinam o que é moralmente relevante; dentre eles, a voz pungente é a do desejo. É preciso haver engajamento afetivo para que a ação seja propriamente correta. Não se pode dizer que é a razão que conduz os afetos, como se estes apenas a seguissem. A razão só vê o que é certo porque estamos 
afetivamente propensos a ver. Os afetos, ao se constituírem como disposições, atuam como certos padrões ou regularidades; e estas nada mais são do que modos de raciocinar e perceber. Diante da exigência de uma tomada de atitude, a disposição de nossos afetos nos leva a ver o que é melhor a ser feito. Por isso, nenhuma ação que não seja afetivamente engajada ou motivada poderia ser movida por princípios intelectuais, mesmo que tais princípios sejam práticos, isto é, decisões tomadas aqui e agora.

É neste sentido que cabe ressaltar o quão determinantes são os afetos para a apreensão e atribuição de valor moral à ação. Ora, é mais do que evidente que, segundo a ética aristotélica, as ações ocorrem em função dos afetos que estão em sua origem, pois estes dizem respeito ao prazer e à dor, isto é, ao desejo de busca e de aversão; e o desejo é princípio da ação.

Em uma única frase, podemos resumir o que foi dito até aqui, concluindo esta investigação: a ética de Aristóteles é uma ética da ação e da persuasão, porque estas são as maneiras da razão penetrar o desejo. Reiteramos, assim, a tese de que não é possível escolher deliberadamente o que desejar, mas é possível passar a desejar corretamente a partir da educação do desejo. Sendo assim, vimos que dois momentos distintos são estabelecidos: um em que o desejo não foi ainda educado e outro em que ele passou a ouvir e obedecer à razão. E isto na medida em que nascemos desprovidos de virtude e passamos, por hábito, a adquiri-la. Educar o desejo não é senão tornar-se moralmente virtuoso. Como o desejo é naturalmente a busca indiscriminada por prazer e a recusa de qualquer dor, educar o desejo significa educar a desejar o que de fato é bom e a ter prazer e dor com o que se deve, como e quando se deve. O desejo, uma vez educado, tem como fim o bem agir, ${ }^{182}$ que será apreendido, na particularidade da ação, pela razão. O desejo não educado, por sua vez, é próprio das crianças, dos animais e dos adultos que vivem cegamente segundo os afetos, sem ter ideia do que é belo e verdadeiramente prazeroso, ${ }^{183}$ ou seja, são aqueles que visam o prazer de modo insaciável e indiscriminado: os adultos viciosos, como o perverso e o intemperante, e aqueles que ainda não são propriamente virtuosos nem viciosos, como os controlados e os descontrolados. 
Vimos, portanto, a relação entre desejo e razão do ponto de vista ético, isto é, dissertamos sobre a condição de possibilidade de o desejo ser educado e passar a estar em harmonia com a razão e de como essa possibilidade se realiza. Resta examinarmos como tal educação se efetiva nas virtudes particulares ao analisarmos que tipo de desejo está envolvido em cada disposição virtuosa, pois assim compreenderemos melhor o desejo em geral e sua relação com a constituição da virtude moral. 


\section{Os desejos nas virtudes particulares}

\section{Introdução}

Este capítulo visa iluminar o capítulo anterior - A educação do desejo, pois, tendo dissertado sobre a condição de possibilidade de o desejo ser educado e passar a estar em harmonia com a razão, veremos como tal educação concretamente se realiza nas virtudes particulares. No que se segue, examinaremos como os desejos devem funcionar na constituição das virtudes morais particulares, sobretudo nas virtudes fundamentais da parte não racional: a coragem e a temperança. As outras virtudes particulares serão analisadas de modo breve e tendo em vista apenas o nosso atual propósito investigativo; com exceção da justiça e da amizade, para as quais o filósofo reservou livros inteiros: o quinto para a justiça e o oitavo e novo para a amizade. A análise de como o desejo está presente nestas duas virtudes mereceria um capítulo à parte, visto a sua complexidade. O nosso intuito, no presente momento, é apenas ilustrar a educação dos desejos na constituição de algumas virtudes morais particulares e, para tanto, bastou-nos abordar brevemente o que o próprio filósofo denominou de quadro ou diagrama (diagraphê) das virtudes particulares ${ }^{1}$, estas mesmas examinadas em detalhe do livro III, capítulo 6, até o final do livro IV. Sendo assim, parece ser oportuno que nós analisemos brevemente os tipos de desejos presentes nas

1 Cf. EN II 7: 1107a32-33. A EE também apresenta um quadro similar em II 3: 1220b38-1221a12, denominado esquema (hupographê). 
virtudes morais, visto que a análise de cada virtude e o modo como o desejo se manifesta em cada uma nos dará maior conhecimento sobre o caráter (êthos) e o desejo (orexis) em geral. Nas palavras do filósofo: "nós conheceremos melhor a respeito do caráter ao examinarmos cada um de seus detalhes; desse modo, acreditaremos que as virtudes são mediedades se assim constatarmos em cada caso" (EN IV 7: 1127a15-18). Outra justificativa para o exame das virtudes particulares, desta vez de cunho metodológico, é fornecida em II 7, a saber: as virtudes particulares são apresentadas com vistas a mostrar que cada uma é uma mediedade entre dois extremos, pois:

É preciso que isso seja expresso não somente de modo geral, mas deve também aplicar-se aos casos particulares, pois nos discursos relativos às ações, os gerais são mais vagos, ao passo que os concernentes às partes atingem mais a verdade: com efeito, as ações dizem respeito às coisas particulares, devendo harmonizar-se a elas" (grifo meu) (EN II 7: 1107a27-32).

Entendemos por isso (toûto), da citação acima, a definição de virtude moral fornecida no capítulo anterior. Quanto ao gênero da virtude, sabemos que todas são disposições. Quanto à diferença específica, que são disposições medianas. Por fim, a definição propriamente de virtude moral é a seguinte: "A virtude é, portanto, uma disposição de escolher por deliberação, consistindo em uma mediedade relativa a nós, mediedade delimitada pela razão, isto é, como delimitaria o prudente" (EN II 6: 1106b36-1107a2)2 . Como vemos, além de ser uma disposição mediana, a virtude é uma disposição em agir bem, portanto, em agir conformemente à escolha deliberada (hexis prohairetikê), pois ela foi engendrada primeiramente pelo hábito de ações que não propriamente virtuosas e, posteriormente, aprimorada e mantida por ações propriamente virtuosas, isto é, ações oriundas da boa escolha deliberada. Isso pressupõe que a

2 Optamos por mediedade, segundo a correção de Aspásio, ao entendermos que o particípio feminino dativo hôrismenêi (delimitada) se liga à mediedade, que também está no dativo, e não à disposição, que está no nominativo. Com efeito, é o termo médio que é "como a reta razão prescreve" (EN VI 1: 1138b20; cf. 1138b29), logo, o caráter mediano da disposição virtuosa e não simplesmente o fato de ser uma disposição pressupõe, além da prática de bons hábitos, o exercício da reta razão. Ou seja, é porque a virtude é uma disposição de certo tipo, isto é, mediana, que ela é delimitada pela razão do prudente e não por ser simplesmente uma disposição. Sobre as justificativas para que o termo disposição seja a melhor opção, ver Zingano (2008, ad loc.). 
aquisição plena da virtude moral implica a atuação da reta razão própria do prudente, conjuntamente com a prática de bons hábitos, pois apenas a retitude na razão pode determinar corretamente o bom fim e os bons meios e, consequentemente, a boa escolha. ${ }^{3}$

Em suma, são quatro os elementos que compõem a sua definição: (i) a virtude moral é uma disposição e não uma capacidade (dunamis) ou uma emoção (pathê), tampouco ela é um estado (diathesis) passageiro, como quando dizemos dos estados passionais; (ii) ela é uma disposição oriunda do hábito de se realizar ações deliberadamente virtuosas e não apenas voluntariamente; (iii) ela é uma disposição mediana entre dois extremos constituídos pelos vícios da falta e do excesso; e, por fim, (iv) a sua mediedade é determinada pela reta razão, ou seja, as ações que engendram a disposição mediana devem alcançar um meio-termo determinado pela reta razão, o que implica dizer que o fim a ser realizado teve de ser escolhido deliberadamente do mesmo modo que o prudente escolheria.

Contudo, é preciso esclarecer que nós não trataremos de todos os seus elementos, mas apenas daquele que caracteriza a sua quididade, a saber, o seu atributo de mediedade, pois o exame das virtudes particulares parece explicar bem em que sentido a virtude pode ser definida como uma mediedade. ${ }^{4}$ Com efeito, as virtudes "dizem respeito ao intercurso com as palavras e as ações (1108a10)", e, também "dizem respeito a emoções” (1109b30), pois “a virtude moral é uma mediedade no sentido de ser um meio termo entre dois vícios: um por excesso e outro pela falta; e é tal mediedade por mirar o meio termo nas emoções e ações” (1109a20-2). Isso significa que a virtude é uma disposição mediana com relação às palavras, ações e emoções, ou seja, que a mediedade se aplica a esta matéria (as palavras, ações e emoções).

A ressalva que deve ser feita, contudo, é com relação às emoções, pois a virtude não pode ser dita uma emoção (pathê) mediana nem a capacidade (dunamis) de sermos afetados pelas emoções. Ela é uma disposição em agir bem ou

3 Ver EN VI 1 e 2 . O capítulo anterior, “A educação do desejo", também aborda a necessidade da reta razão e do reto desejo para a escolha ser boa.

4 Logo depois de ter fornecido a definição de virtude moral, o filósofo nos diz que a mediedade é a sua essência ou quididade: "É uma mediedade entre dois males, o mal por excesso e o mal por falta. Ainda, pelo fato de as disposições faltarem umas, outras excederem no que se deve tanto nas emoções como nas ações, a virtude descobre e toma o meio termo. Por isso, por essência (ousia) e pela fórmula que exprime a qüididade (to ti ên einai), a virtude é uma mediedade, mas, segundo o melhor e o bem, é um ápice” (EN II 6: 1107a2-6). 
mal com relação às emoções. Por isso, não somos elogiados por sentirmos ou desejarmos de certo modo, mas por agirmos de certo modo diante de nossas emoções e desejos. ${ }^{5}$

Sendo assim, a característica essencial da virtude é a sua mediedade, pois ela é uma disposição em agir na justa medida com relação às emoções. Podem ser elogiadas como virtuosas, portanto, nossas ações e palavras, mas não as nossas emoções, senão indiretamente. De todo modo, não podemos negar que o objetivo é encontrar a justa medida nas emoções e desejos. Ora, podemos dizer "que há também mediedade nas afecções e no que é acerca das emoções, pois o pudor não é uma virtude, mas o pudico é louvado" (1108a31). Sabemos que o pudor ou a vergonha (aidos) não é uma disposição virtuosa, mas sim uma emoção mediana entre o despudorado, aquele que em geral não tem pudor, e o acanhado, aquele que tem pudor em relação a tudo. Porém, por que seria o pudor uma emoção e não uma virtude? Podemos supor que o filósofo acredite que nós não podemos constituir uma disposição em agir bem com relação ao pudor. Trata-se de ter ou não pudor e não de se portar bem ou mal com relação ao pudor. Em suma, o pudor é uma emoção a partir da qual não se constitui uma disposição, seja virtuosa ou viciosa, porque não podemos desejar e praticar ações para sermos pudicos ${ }^{6}$, assim como podemos fazer em relação a outras emoções ou afecções, como a cólera, o medo e o apetite. Como veremos na análise do livro IV, capítulo 9, o pudor se engendra a partir do medo de ser censurado ou desonrado. Ele é uma emoção antes necessária à educação do jovem, que por pudor evita praticar atos vis, do que para um adulto; a não ser que este adulto seja um controlado (enkratês) que, por pudor, se controle para não agir erradamente. No mais, o virtuoso, supostamente, não sente pudor, pois não há do que se envergonhar de suas belas ações.

Do mesmo modo, a indignação (nemesis) ${ }^{7}$ é dita uma emoção e não uma virtude. Certamente uma emoção mediana, portanto elogiável, pois se encontra

5 Como foi dito claramente em EN II 4 (1105b20-1106a10).

6 Como diz Ross (1923, p. 209), o pudor e a indignação são "duas qualidade que não são virtudes, pois elas não são disposições da vontade (will). Estes últimos são estados medianos e são louvados, mas eles são estados medianos de emoção e não atitudes da vontade em relação à emoção. Em Ética Eudêmia (III, 7), o pudor e a indignação são concebidos como qualidades instintivas a partir das quais se engendra respectivamente a temperança e a justiça”.

7 A indignação não é discutida na EN IV e sim na Ret. II 9. 
no meio termo entre a inveja (phthonos) e a malevolência (epichairekakia). Trata-se de uma emoção, pois somos afetados sentindo prazer ou dor diante do êxito ou fracasso de pessoas próximas. Não nos esforçamos para nos tornarmos indignados por prática de ações, como ocorre com a constituição de qualquer virtude; ou sentimos indignação ou não sentimos. Sentir apenas prazer ou dor, sem promover ações ou discursos, não provoca nenhum dano ou benefício ao outro; logo, não se trata de se comportar bem ou mal, mas de ter ou não certa emoção, de indignar-se ou não corretamente. Como nos diz o filósofo:

Quem tem indignação aflige-se em face dos que imerecidamente têm êxito; o invejoso, excedendo, aflige-se de todos; <quem tem indignação aflige-se ante os que imerecidamente fracassam,> o malevolente está tanto em falta quanto ao afligir-se que mesmo se alegra (EN II 7: 1108b1-6).

Em suma, a indignação não implica necessariamente uma ação, tampouco o pudor. Por isso, devem ser entendidas como emoções que não engendram disposições. Emoções que, certamente, revelam de algum modo o zelo pelo outro, no caso da indignação, e o zelo em não cometer ações censuráveis, no caso do pudor.

Com relação à cólera, que também é uma emoção, ocorre diferentemente, pois não se trata de ter ou não cólera - todos nós a temos naturalmente; mas de se portar bem ou mal com relação a ela. Nas palavras de Aristóteles:

Por disposições < entendemos> aqueles estados em função dos quais nos portamos (echomen) bem ou mal com relação às emoções: por exemplo, com relação ao encolerizar-se, se nos encolerizarmos forte ou fracamente, portamo-nos mal; se moderadamente (mesôs), bem, e de modo semelhante com relação às outras emoções (EN II 4: 1105b26-29).

Enfim, tendo distinguido disposição e emoção, bem como a relação entre elas, fica evidente que a virtude é uma disposição em agir moderadamente, ou melhor, na justa medida com relação às emoções. Agir moderadamente implica agir conforme o justo meio, este mesmo determinado pela reta razão.

A partir da leitura do capítulo 9 do livro II, bem como dos últimos capítulos do livro III e de todo o IV livro da Ética Nicomaqueia, podemos notar que as virtudes se distinguem pelos seus objetos. Podemos dizer que todas dizem respeito ao se dispor e se portar bem com relação ao prazer e a dor, portanto, com 
relação, sobretudo, ao impulso e ao apetite. As disposições corajosa e tolerante são a expressão, por excelência, da ação virtuosa referente à dor, pois que o seu objeto é o enfrentamento correto da dor ${ }^{8}$. Também podemos afirmar que é a disposição temperante que mais diz respeito à ação virtuosa referente aos prazeres do tato e do paladar, pois que o seu objeto são os prazeres que pertencem às atividades como comer, beber e fazer sexo.

As outras virtudes também concernem ao prazer e à dor, ou seja, às emoções e ações acompanhadas de prazer ou dor, mas se referem, por sua vez, a outros objetos que não o próprio prazer e a própria dor. Assim, três virtudes - a temperança, por um lado, e a coragem e a tolerância, por outro - dizem respeito respectivamente ao prazer e à dor ou cólera. Além do prazer, outros dois objetos são essencialmente objetos de busca para os homens: a riqueza e a honra. Assim, duas virtudes concernem aos bens materiais: como a generosidade e a magnificência. Ainda outras duas dizem respeito às honras: como a magnanimidade e a ambição adequada. Por fim, seguindo a classificação de Ross, ${ }^{9}$ três outras virtudes dizem respeito ao convívio com os outros, às relações sociais, a saber: a sinceridade, o bom-humor e a amabilidade. ${ }^{10}$ Quando o objeto é a verdade, a disposição é a da sinceridade ou veracidade. Quando se trata do agradável no que diz respeito à diversão, a disposição mediana é aquela que pode ser denominada de bom-humor; e aquela que diz respeito ao que é agradável na vida em geral pode ser compreendida como amabilidade. Quanto ao que é justo, a disposição correspondente é a justiça.

\section{A temperança e a coragem}

Sabemos que a temperança (sôphrosunê) e a coragem (andreia) são fundamentalmente virtudes da parte não racional da alma, ${ }^{11}$ sendo a segunda, uma disposição mediana entre a covardia (deilos) e a temeridade (thrasus) e, a primeira,

8 Como diz Ross (1923, p. 209), ter coragem "é essencialmente o encarar daquilo que é doloroso".

9 Ross (1923, p. 209) estabelece três agrupamentos para as várias virtudes particulares: o primeiro diz respeito aos sentimentos de prazer, dor, medo e cólera; o segundo, aos dois principais bens buscados pelos homens: a riqueza e a honra; e o terceiro, às relações sociais.

10 Em concordância com Ross, Gauthier (2002, tome II, p 304-305) afirma que essas três virtudes são virtudes da vida social e podem ser compreendidas por "veracité, amabilité et enjouement".

11 Cf. EN III 10: 1117b23-25. 
uma disposição mediana entre a intemperança (akolasia) e o vício pela falta que não possui nome, embora o filósofo nos diga que tal disposição em deficiência é rara e que esta pessoa que não sente prazer algum sofre uma espécie de anestesia ou insensibilidade (anaisthêsia), podendo ser denominada insensível (anaisthêtos). ${ }^{12}$ Também sabemos que os desejos são da parte não racional da alma e que dois deles, o apetite e o impulso, são mais avessos à razão do que o querer. O impulso e o apetite se distinguem um do outro por várias características, mas sobretudo por seus objetos. O objeto do impulso é a dor e o do apetite, o prazer. Por isso, como veremos, a temperança se constitui a partir da educação do apetite; enquanto a coragem, a partir da educação do impulso, do desejo de aversão ou de enfrentamento da dor, sendo a mediania entre o medo (phoberon) e confiança (tharrê). Isso porque o excesso de medo, a fuga da dor que deve ser enfrentada, constitui a falta de coragem, isto é, a covardia. Já o excesso de confiança, o enfrentamento da dor que não deve ser enfrentada, constitui o excesso de coragem, isto é, a temeridade. Em nossa análise, não tomaremos apenas o sentido estrito de coragem, cujo objeto se restringe ao enfrentamento da dor da morte e em que ser corajoso propriamente significa não temer uma morte gloriosa em batalha; também aceitaremos o sentido largo do corajoso, cujo objeto inclui enfrentar corretamente certos perigos, pobrezas, ações vis, doenças, mesmo que estas ações não coloquem em risco a vida (1115a25-b5). Os corajosos por homonímia, cujo fim da ação não é o próprio ato corajoso, descritos em EN III 8 (1116a16-1117a28), foram excluídos da análise, pois o nosso intuito é empreender uma análise mais abrangente da natureza e da atuação do impulso. Veremos, assim, que o impulso educado pode ser entendido enquanto um ímpeto para enfrentar corretamente a dor atual ou a do perigo iminente, como faz o corajoso, mas também para o encolerizar-se encolerizá-lo na justa medida diante de uma dor sofrida por um desprezo ou ultraje desmerecido, como faz o ponderado ou tolerante.

No caso do enfrentamento correto da dor, o filósofo nos diz que "é por enfrentar (hupomenein) a dor que, como foi dito, os homens são chamados corajosos” (EN III 9: 1117a34). Já com relação à cólera, ele nos diz que:

Há também excesso, falta e mediedade, mas como praticamente eles não têm nome, chamemos quem está no meio termo de ponderado (praos) e 
a mediedade de ponderação; dos extremos, seja quem excede irascível (orgilos) e o vício, irascibilidade; quem está em falta, apático (aorgêtos); a falta, apatia (EN II 7: 1108a5-9).

Sendo assim, o impulso educado é aquele que consegue conviver bem com a dor presente, passada e futura. Ou seja, ser educado quanto ao impulso é saber encontrar a justa medida para a emoção e o desejo de agir em relação à dor. É, enfim, tornar-se corajoso e ponderado.

Aristóteles, ao mostrar que a coragem por impulso apenas deve ser dita coragem por homonímia, torna evidente que a ação corajosa não é uma ação naturalmente impulsiva, mas uma ação impulsiva racionalmente orientada, pois, certamente, a coragem não pressupõe o nosso desejo de enfrentamento da dor in natura, mas que ele seja educado, isto é, orientado pela razão que visa o belo:

A coragem por impulso parece ser mais natural, e, quando acrescida de escolha deliberada e finalidade, ela é de fato coragem. Os homens, portanto, como os animais, também sofrem quando estão coléricos, e sentem prazer quando se vingam. Aqueles, porém, que lutam por causa dessas coisas, embora valentes, não são corajosos, pois não lutam pelo que é belo (kalos), nem como dita a razão, mas por emoção (pathos) (EN III 8: 1117a2-9).

Ou seja, não basta ter naturalmente o impulso de enfrentar a dor ou ser capaz de sentir cólera para ser corajoso. Se bastasse o pathos, o desejo impulsivo que nos é natural, sem que ele fosse lapidado pela razão, admitiríamos a coragem por impulso como sendo propriamente coragem. Se assim fosse, teríamos que naturalizar a virtude e atribuí-la igualmente (e não apenas por homonímia) aos animais. Por exemplo, animais que enfrentam aqueles que o feriram são ditos corajosos, pois de fato o corajoso é impetuoso e é característico do impulso enfrentar o perigo (1116b24-1117a9). Porém, ao contrário dos animais, "os corajosos agem por causa do belo, embora o impulso opere conjuntamente neles; e os animais agem por causa da dor, pois eles atacam por terem sido feridos ou por temerem” (1117b31-33).

Uma vez tendo excluído a coragem por impulso da definição própria de coragem, o filósofo passa a criticar aquela assim referida por temperamento ou tipo sanguíneo (euelpides): ambas devem ser consideradas casos de coragem por homonímia. O texto segue, assim, criticando justamente a insuficiência da explicação naturalista, mas agora se referindo ao fisiologismo de se atribuir 
coragem ao homem de tipo sanguíneo. O homem de tipo sanguíneo acredita ser mais forte do que os demais, e age não pelas boas razões e nem tendo em vista o bem, mas sendo orientado por, digamos, um excesso de autoconfiança. E se, por acaso, as coisas não vão bem, ele rapidamente se esquiva (1117a9-22).

Com relação à temperança, é o apetite que deve ser educado para que tal disposição venha a ser adquirida. Sabemos que o desejo pelo prazer presente em nós desde a nossa tenra infância é insaciável e indiscriminado:

Por isso, os apetites devem ser moderados e poucos, e nunca se oporem à razão (logos) - isto é o que chamamos de disciplinado (eupeithes) e comedido (kekolasmenon). A parte apetitiva deve ser conforme a razão (to epithumêtikon kata ton logon), assim como uma criança deve viver em obediência ao seu tutor. Portanto, no temperante, a parte apetitiva deve estar em harmonia com a razão (to epithumêtikon sumphônein tôi logôii); pois ambos, temperança e razão têm em mira o belo; e o temperante tem apetite com o que se deve, como e quando se deve, assim como ordena a razão (tattei ho logos) (EN III 12: 1119b11-18).

Em suma, como foi dito acima, o apetite educado é aquele que deseja o que é prazeroso segundo o que ordena a razão (logos) que, neste caso, deve ser entendida como reta razão (orthos logos), isto é, aquela que apreende verdadeiramente o bem. O apetite educado, próprio do temperante, é aquele que tem prazer com o que se deve, como e quando se deve. Similarmente, o impulso educado, como vimos, é aquele que enfrenta a dor que se deve, como e quando se deve.

Mesmo que, de modo geral, a coragem seja a expressão do impulso educado, do bem lidar ou conviver com a dor, e a temperança, a expressão do apetite educado, do desejar retamente o prazer, não poderíamos nos contentar com esta dicotomia simplória, desconsiderando a relação que cada disposição tem tanto com o prazer como com a dor. Vejamos ainda, com mais minúcia, o que significa dizer que o corajoso também deve ter apetites corretos e o temperante, impulsos corretos.

Primeiramente, sabemos que o corajoso não deve ter como fim o prazer da honraria subsequente ao seu ato ou o que quer que seja extrínseco ao fim virtuoso; ao contrário, ele deve desejar exclusivamente o bem e a beleza de se agir corajosamente (1117a35 e ss). ${ }^{13}$ Isso significa que o seu apetite deve ser 
minimamente educado para que ele tome como prazeroso o fim corajoso e não a honra consequente.

O temperante, por sua vez, deve enfrentar a dor por não ter obtido o prazer desejado, sem sofrimento; ao contrário do intemperante que sofre desmedidamente nesta situação (1118b28-36). Isso significa que, mesmo que o apetite seja determinante para a constituição da temperança, o homem temperante tem que ter o seu impulso educado para, pelo menos, poder evitar prazeres indevidos. Da mesma maneira, ainda que a educação do impulso seja essencial para o corajoso, o seu apetite não pode direcionar a sua ação para a honraria que é, ela própria, extrínseca ao ato corajoso.

Para finalizar a nossa análise da operação do apetite e do impulso na coragem e na temperança, é importante termos claro o grau de voluntariedade ao compararmos desejo, ação e disposição. Sabemos que os homens não são censurados por sentirem simplesmente certa afecção, desejo ou emoção; quanto às disposições, porém, diríamos que somos em parte censurados pelo modo como costumamos agir, isto é, pelo que somos ou não somos; quanto à ação, podemos ser completamente censurados, pois somos inteiramente responsáveis pela ação que esteja sob o nosso poder. Isso significa que a voluntariedade e, portanto, a responsabilidade sobre a disposição em desejar é parcial, mas quanto à ação, ela é integral. Ou seja, não somos diretamente responsáveis pela disposição adquirida, pois que ela é a adquirida pela regularidade de certas ações sobre as quais somos direta e inteiramente responsáveis. Isso significa que, como somos indireta ou parcialmente responsáveis pela disposição, e como é a disposição que põe o desejo, logo, somos indireta e parcialmente responsáveis por certas regularidades no nosso modo de desejar. O desejar, todavia, não se reduz a certas regularidades, não se constitui única e exclusivamente a partir de nossas propensões ou disposições. Há, certamente, além do caráter determinante das disposições, cuja fixidez não parece ser intransponível, muitas variáveis em jogo que são contingentes, circunstanciais e eventuais, como os estados passionais em que possamos nos encontrar - uma paixão cega, uma raiva desmedida, um amor excessivo, um ciúme doentio etc.

Porém, ao comparar duas disposições, o que levaria o filósofo a dizer que “a intemperança parece ser mais voluntária do que a covardia” (EN III 12: 1119a22-3)? Ora, ninguém, de bom grado, gostaria de ser um intemperante; ninguém se esforçaria para se tornar escravo de seus próprios caprichos. Como 
diz Aristóteles, "para o intemperante, por um lado, as ações particulares são voluntárias, pois ele as faz com apetite, isto é, com desejo; mas a disposição em geral é menos voluntária, uma vez que a ninguém apetece ser intemperante" (EN III 12: 1119a31-34). Portanto, a afirmação de que a intemperança é mais voluntária que a covardia deve ser entendida do seguinte modo: como a ação intemperante é mais voluntária do que a ação covarde, a disposição respectiva será consequentemente mais voluntária; o que não significa dizer que alguém que busque prazeres imoderados esteja, no fundo, buscando se tornar intemperante; ele está apenas preocupado em obter o prazer desejado aqui e agora e não em quem ele irá se tornar por agir assim regularmente. É provável que ele seja insensível ou insensato por não se dar conta que repetidas ações engendram necessariamente certa disposição (EN III 5: 1114a13-15).

Por fim, concluímos que a ação por apetite é mais voluntária do que a ação por impulso, pois a dor possui, em alguma medida, uma força compulsória que nos impele seja a evitá-la, seja a reagir vingativamente, como já foi dito; ao contrário do prazer, cuja natureza em nada nos repele, mas antes nos atrai naturalmente. Ora, a dor é para ser, por natureza, evitada (pheukton); enquanto o prazer, buscado (haireton). Isso é evidente se considerarmos que a dor extrema pode nos destruir e o prazer não. Todavia, sabemos que é mais difícil combater o prazer do que o impulso, mesmo que a ação por apetite seja mais voluntária do que a por impulso. Isso significa que, embora a ação por apetite esteja mais sob o nosso poder, de modo que possamos igualmente dizer sim ou não à satisfação de um prazer, ainda assim, não é por este motivo que se torna mais fácil governar os prazeres do que enfrentar e conviver com a dor. E isso por uma única razão: o apetite é menos capaz de ouvir a reta razão do que o impulso. Ou seja, paradoxalmente, a ação por impulso é menos voluntária, mas o impulso é mais educável; enquanto a ação por apetite é mais voluntária, mas o apetite é menos educável. Isso significa que a educação de certo desejo não pressupõe que a ação motivada por ele seja mais ou menos voluntária, mas que a sua natureza seja mais ou menos capaz de ouvir a razão. De qualquer forma, sabemos que a educação de tais desejos não apenas é possível, como é igualmente necessária, pois a disciplina com relação aos prazeres é fundamental para que fruamos daqueles que são naturalmente bons prazeres na boa medida. Ao mesmo tempo, o enfrentamento adequado das dores é imprescindível para que não deixemos de realizar belas e boas ações por medo e possamos nos encolerizar na boa medida e na hora certa. 


\section{A generosidade}

No livro IV da Ética Nicomaqueia, capítulo 1 (1119b22-1122a18), Aristóteles analisa a virtude da generosidade (eleutheria), que é o meio termo entre o esbanjamento (asôtia) e a avareza (aneleutheria). Trata-se da virtude da boa medida quanto aos bens materiais, da disposição para dar e ganhar bens adequadamente, o que pressupõe saber para quem se deve dar, quando se deve dar e de onde se deve tirar. Para tanto, é preciso, sobretudo, educar a parte apetitiva. Isso é evidente se tomarmos o vício pelo excesso: o esbanjamento. O esbanjador se aproxima do intemperante ao agir por apetite e contrariamente ao que é belo (kalos). Ele dá bens, muitas vezes, não com vistas ao belo, mas esperando receber prazer em troca (1121b3-11). Por isso, "o esbanjador erra com relação a essas coisas, pois ele não sente prazer nem dor com o que se deve e como se deve” (1121a89). Já o vicioso por falta, o avaro, caracteriza-se por não dar nada e ainda retirar o que pode, mesmo que seja de fontes impróprias. É aquele que possui uma ganância sórdida e não mede esforços para obter os bens desejados. Como nos resume Aristóteles:

A respeito do dar e receber bens, a mediedade é a generosidade, o excesso e a falta são o esbanjamento e a avarícia. Excedem e estão em falta quanto a isso em direção contrária, pois o esbanjador excede em oferecimento e está em falta em recebimento, o avaro excede em recebimento e está em falta em oferecimento (EN II 7: 1107b9-14).

Segundo a análise desta virtude, parece plausível afirmar que o ávaro age por apetite, isto é, pelo prazer da avareza ou mesquinharia, portanto, contrariamente à razão. E se ele agir contrariando o seu apetite pela ação mesquinha, dando e recebendo conforme o que é correto e belo (to deon kai to kalôs), ele sentirá dor acima do normal. Já o generoso, "se acontecer de ele gastar de uma maneira contrária ao devido e belo, ele sentirá dor na medida certa e como se deve; pois é próprio da virtude sentir prazer e dor com o que se deve e como se deve" (1121a2-4).

É tese aristotélica bem estabelecida e reafirmada neste capítulo que "é próprio da virtude sentir prazer e dor com o que se deve e como se deve” (1121a4); o que pressupõe, portanto, a educação dos desejos que concernem ao prazer e à dor: o apetite e o impulso, como vemos no caso da generosidade e nas demais virtudes analisadas a seguir. 


\section{A magnificência}

Quanto à magnificência (megaloprepeias), examinada no livro IV, capítulo 2 (1122a18-1123a33), não há muito que discorrer além do que já foi dito sobre a generosidade, ${ }^{14}$ uma vez que o homem magnificente é generoso, porém dele se diferencia pelo objeto: ele trata de grandes despesas para grandes obras. A grandeza não diz respeito somente à quantidade de dinheiro a ser empreendido, mas sobretudo à beleza da obra. Portanto, o homem magnificente não apenas necessita de uma grande quantia de dinheiro, mas também deve saber onde e como aplicá-la. Vale a pena enfatizar que, para tal virtude, principalmente o apetite deve ser educado e estar subordinado à beleza do fim (tou kalou hêneka), "pois isto é comum às virtudes" (1122b8), ou seja, toda virtude tem um belo fim em vista.

Sendo assim, o magnificente gasta grandes somas com prazer e em vista do belo (1122b8-9). Já o homem vulgar (banausos), em sua vulgaridade e falta de gosto, erra por excesso de dispêndio em obras pequenas ou insignificantes, e assim o faz em vista não do que é belo, isto é, da própria ação magnificente, mas em vista da consequente exibição de sua riqueza e do prazer de a admirarem (1123a24-28). Ele erra, portanto, ao sentir prazer com o que não deveria. O erro por falta se caracteriza, por sua vez, em sentir dor com o que não se deve, pois o mesquinho (mikroprepês) lamenta a dor de se supor gastando mais do que se devia: assim, acaba por estragar a beleza da obra por ninharia.

\section{A grandeza de espírito}

A megalopsiquia, examinada no livro IV, capítulo 3 (1123a34-1125a35), que pode ser traduzida por grandeza de espírito ou magnanimidade, explica-se pela figura do homem de altaestima. ${ }^{15}$ Aquele que honra o que faz ou que busca a

14 Isto também é afirmado em EN II 7: 1107b16-20.

15 Ross (1923, p. 214) compreende esta virtude do seguinte modo: "Great-souledness, or as we may call it, proper pride, or self-respect". No entanto, para o mesmo, a figura do magnânimo é, em seu conjunto, desagradável e mostra, de alguma maneira, "o narcisismo constitutivo do lado mau da ética de Aristóteles" (ROSS, 1923, p. 214). Na mesma direção de Ross (1892, p. 337), Stewart, em sua nota introdutória ao capítulo, expõe o estranhamento que muitos comentadores tiveram diante desta figura, que pareceria ser antes um homem ideal do que real, pois, se fosse real, seria intolerável; afinal, seria bastante desagradável uma pessoa que, em geral, desprezasse a admiração dos outros e fosse irônica com muitos; por isso "the description of the megalopsuchos in the Ethics is rather the 
honra merecida pelo que faz na justa medida, pois se trata de uma mediedade na busca da honra. Enquanto o homem de grandeza de espírito valoriza o que faz e merece ser valorizado pelo que faz, o presunçoso (chaunos), em sua vaidade, valoriza excessivamente o que faz, exigindo mais honra do que mereceria. Já o humilde, que peca pela pequeneza de espírito (mikropsuchos), valoriza o que faz menos do que merece. Enquanto o humilde não é vil por se diminuir, pois sua opinião apenas o torna pior do que o que ele é atualmente, o presunçoso é vil, pois a suposta falta de percepção de si é maliciosa. Ele é do tipo que vive querendo ostentar o que não é ou o que não tem, apenas para ser admirado ou bajulado. Assim sendo, o homem de grandeza de espírito tem a boa disposição quanto às honras e desonras; enquanto o presunçoso erra por excesso, o humilde, por falta.

Como a honra é o "prêmio" da virtude, ser honrado é como o coroamento de quem é virtuoso. Por isso, o homem de grandeza de espírito é honrado por ser virtuoso e, como diz Aristóteles, ele não pode ser senão um homem bom (1124a25). Ademais, como o homem magnânimo é completamente virtuoso, uma vez que a honra e a grandeza de espírito não existem sem a virtude completa (aneu aretês pantelous) (1124a29-30), ele terá a coragem, a temperança e todas as demais virtudes. Com relação ao exame do desejo, neste caso, basta dizer que o magnânimo consegue o perfeito equilíbrio entre a razão e o desejo. Como ele tem a boa disposição para a honra, ele sabe desejá-la como e quando convém. Portanto, ele não tem a honra como finalidade de suas ações, mas sim a própria virtude. Ou seja, ele jamais valorizará a honra acima da própria virtude, o que implica uma constante disciplina e governo sobre o prazer em receber honra. Sendo assim, é evidente que ele possui um prazer moderado em receber apenas aquilo que em verdade lhe pertence, a honra que de fato ele merece (1124a5-8). Por isso, com relação à boa e má fortuna, aos bens e males externos, sendo a honra o maior bem externo, ele não sente nem dor nem prazer excessi$\operatorname{vos}(1124 \mathrm{a} 12-20)$.

Neste capítulo, Aristóteles surpreendentemente lista todas as qualidades morais do homem magnânimo, que são as mesmas do homem perfeitamente ou completamente virtuoso. Ele assim o faz com tal detalhamento, que não encontramos na descrição das outras virtudes morais; como que nos dando o 
que poderíamos chamar de uma espécie de "manual dos bons modos”. Vejamos a lista de qualidades que deve satisfazer o homem de grandeza de espírito: ele deve ter todas as virtudes; deve dar em preferência de receber; ajudar prontamente em preferência de ser ajudado; desprezar o insolente; não sobrepujar os mais fracos; ser claro, isto é, transparente; ser sincero no amor e no ódio; não se esconder na timidez, isto é, no medo da exposição; prezar antes a verdade do que a opinião alheia; falar e agir com clareza, isto é, ser franco, falar abertamente; não viver em função do outro, à exceção do amigo, pois isto é servil e típico de bajuladores; não se orgulhar em ser admirado; não se ater demasiado aos erros, mas lembrar, sobretudo, dos bons feitos; não ser fofoqueiro, ou seja, não se importar em ser elogiado, nem diminuir os outros ou falar mal dos outros, nem mesmo dos inimigos, a não ser por desprezo; ser, portanto, autárquico, isto é, autossuficiente; ser calmo e tranquilo, o que deve transparecer em seu andar lento, na voz profunda e no domínio da palavra, isso porque ele leva poucas coisas a sério, ao contrário dos apressados e dos agitados.

\section{A ambição}

Quanto ao amor à honra ( philotimia), examinada no livro IV, capítulo 4 (1125b126), não há muito que acrescentar além do que já foi dito sobre a grandeza de espírito, pois ela é como que uma espécie desta virtude; assim como a magnificência o é da generosidade. ${ }^{16}$ Enquanto a grandeza de espírito diz respeito a grandes honras, o amor à honra diz respeito a pequenas honras. Trata-se de ter uma boa disposição em relação ao desejo (orexis) pela honra, pois "é também possível desejar a honra mais ou menos do que se deve, de onde e como se deve" (1125b8-9). O problema é que os extremos possuem nomes: o amor excessivo à honra (philotimia) é chamado de ambição, ou, como costumamos dizer em português, ganância; já a ausência de tal amor denominamos de falta de ambição ou humildade (aphilotimia). O meio termo, por sua vez, encontra-se sem nome. Porém, como há extremos, diz o filósofo, deve haver um meio termo e nós elogiamos aquele que deseja a honra ou que tem ambição na medida certa e pelas fontes certas. Em suas palavras: 
Com efeito, é possível desejar honrarias como se deve, bem como mais e menos do que se deve, e quem excede em seus desejos é dito ambicioso (philotimos), quem está em falta é humilde (aphilotimos); quem está no meio termo não tem nome. Os estados também não têm nome, exceto o do ambicioso: ambição (philotimia). Por isto os que estão nos extremos outorgam-se o espaço do meio termo, e nós também chamamos quem está no meio termo por vezes de ambicioso, por vezes de humilde; por vezes louvamos o ambicioso; por vezes, o humilde (EN II 7: 1107b27-1108a1).

Diante de tal ambiguidade referente à denominação do meio termo, poderíamos designar o meio termo de ambição própria. ${ }^{17}$ Já o extremo por excesso, que também pode ser chamado de ambição, seria, no caso, melhor designado por ambição imprópria, ou ganância. Com efeito, visto se tratar de uma virtude moral, é preciso haver a educação do desejo por honras. Este deve existir na justa medida, portanto, sempre subordinado ao desejo pelo belo, sendo o verdadeiro ambicioso aquele que ama o belo (philokalos), faz o belo e, por isso, é honrado.

\section{A tolerância}

Se, como vimos, com relação ao prazer, a educação do apetite deve, sobretudo, engendrar a disposição mediana chamada temperança, com relação à dor, a educação do impulso deve constituir fundamentalmente duas disposições medianas: a coragem e a tolerância (praotês), virtude examinada no livro IV, capítulo 5 (1125b27-1126b10).

17 Gauthier (2002, tome II, p. 299-301), por exemplo, a designa por ambição legítima (l'ambition légitime), pois, para ele, apesar de ela ser inferior à magnanimidade, ela seria, ainda assim, legítima. Diferentemente, Stewart (1892, p. 347) está antes preocupado em nomeá-la de modo a ser coerente com a análise do capítulo e, por isso, propõe que "nós talvez possamos chamá-la de Ambição Própria (Proper Ambition)”; exatamente da mesma maneira que nós entendemos esta virtude anônima. Porém, segundo Stewart (1892, p. 347), ela não deve ser considerada apenas como sendo quantitativamente distinta da magnanimidade, como parece propor Aristóteles aqui e em II 7, mas deve ser qualitativamente distinta, pois a sua honra diz respeito ao reconhecimento social, enquanto a honra do magnânimo é a expressão da sua vida como um todo, do uso excelente de da sua scientia intuitiva. A nosso ver, a diferença é tanto quantitativa como qualitativa, pois a honra do ambicioso é menor e diz respeito ao reconhecimento social, enquanto a do magnânimo é maior e é expressão o seu amour propre. 
A coragem diz respeito, principalmente, ao enfrentamento da dor na batalha, portanto, ela é uma disposição virtuosa própria ao guerreiro. Já a tolerância ou o bom temperamento diz respeito ao enfrentamento da dor em situações ordinárias relativas aos insultos e ofensas recebidos imerecidamente. Tendo em conta essas duas disposições, podemos inferir que, grosso modo, o enfrentamento da dor se refere às dores temíveis, que virão futuramente, ou às dores padecidas injustamente. Diante da dor futura ou iminente, é preciso coragem para enfrentá-la. Diante da dor passada, já sofrida, é preciso ter cólera na boa medida para enfrentá-la, pois é após ter sofrido com um "manifesto desprezo contra si mesmo ou contra alguém próximo, sem que o desprezo seja merecido" (Ret. II 2: 1378a32), que a cólera surge enquanto um desejo de vingança.

A pessoa tolerante é aquela que enfrenta a dor sofrida como é preciso, tendo cólera com o que se deve, como, quando, contra quem e por quanto tempo se deve segundo as circunstâncias envolvidas. Por isso, o impulso educado é aquele que é orientado conforme a reta razão. Neste sentido, o filósofo afirma que "a pessoa tolerante quer ser tranquila e não guiada pela emoção, mas pelo que ordena a razão (hôs an ho logos tazêi)" (1125b34-35). ${ }^{18}$ Trata-se antes de querer ser orientado pela razão e evitar ser guiado pela emoção do que simplesmente saber o que deve ser feito em uma dada situação. O desejo precisa desejar o que diz a razão, o que pressupõe um esforço contínuo para a obtenção e manutenção da disposição mediana (1126b9).

O excesso é chamado de irascibilidade (orgilotês). Já a deficiência é chamada de falta de espírito (aorgêsia). A falta de cólera, a excessiva passividade parece provir da falta de sofrimento com um insulto ou ofensa que normalmente provocaria dor, pois, segundo Aristóteles, é preciso sofrer como se deve sofrer, ou seja, é preciso encolerizar-se com certas injustiças e enfrentar a dor sofrida com moderação.

18 Vemos aqui que o significado de tolerância parece estar atrelado à tranquilidade ou à ausência de perturbações (atarachos), vocabulário ainda incipiente na filosofia aristotélica, mas que fará fortuna no ceticismo antigo. Este parece ser o motivo pelo qual Gauthier traduz esta virtude por placidité, ou seja, calma, tranquilidade, serenidade. Ross e Stewart preferem gentleness ou good-temper, o que enfatiza antes o comportamento gentil, simpático, amigável e moderado com o outro e menos um modo de ser calmo ou sereno. Acreditamos que o termo tolerância pode se aproximar de um comportamento calmo ou moderado, mas parece antes ressaltar até que ponto devemos agir com cólera, ou, como dizemos, o que e como devemos tolerar ou não, pois nem todo insulto deve ser tolerado, ou melhor, todo insulto deve ser tolerado na medida certa; afinal, é preciso se encolerizar de um certo tanto e modo conforme cada situação particular. 
Quanto ao excesso de cólera, há três tipos de manifestações pelas quais o impulso encontra vazão contrariando a justa medida: o irascível ou colérico em excesso (orgiloi); o ressentido ou vingativo em excesso (pikroi dusdialutoi) e o de temperamento ruim (chalepoi). O irascível encoleriza-se por qualquer motivo, liberando de modo indiscriminado e desorientado o seu impulso, porém seu sentimento colérico extingue-se tão rapidamente quanto começou. O ressentido, por sua vez, retém sua cólera por muito tempo e, quando a libera, por ela ter sido demasiadamente contida, a sua força é tamanha que ela só diminuirá se houver vingança ou, passado certo tempo, se ela tiver sido bem digerida, esquecida, sublimada. Já a pessoa de temperamento ruim consegue ser pior do que o ressentido, pois ele só aplaca a sua cólera com o prazer da vingança ou da punição, ou seja, ele não é capaz de superar a dor sofrida sem que ele não provoque sofrimento em troca e ainda sinta prazer nisso. Por fim, a gravidade moral, como vimos, encontra-se antes no excesso do que na falta de cólera, sendo o acerto a mediedade.

\section{A amabilidade}

A disposição para se dedicar ao outro e causar-lhe prazer como convém, examinada no livro IV, capítulo 6 (1126b11-1127a11), por não ter um nome na língua grega, pensamos ser o caso de denominá-la com um termo em nossa língua que parece ser adequado ao caso: a amabilidade. ${ }^{19}$ Se as outras disposições eram tendências saudáveis na busca do prazer e no enfrentamento da dor com relação a si mesmo e ao outro, esta disposição, como veremos, tem como objeto exclusivamente o outro, ou seja, ela se refere ao que é agradável na vida em geral (peri to hêdu en tôi biôi) (1108a26) e não apenas em situações divertidas, como é o caso do bom-humor, mas, como veremos, no que diz respeito ao outro, portanto, em situações de sociabilidade.

Enquanto o obsequioso ou o excessivamente complacente (areskos) exagera em apenas querer dar prazer e jamais provocar dor, mesmo que seja simplesmente por ter prazer em dar prazer, sem ter em vista a obtenção de dinheiro, como faz o bajulador (kolax). O beligerante ou quereloso (duseris) e o grosso ou

19 Assim também, Gauthier (2002, tome II, p. 304) diz que "ela é o que nós nomeamos em francês de amabilidade (amabilité) ou a afabilidade (affabilité)"; e Ross (1923, p. 210) a denomina friendliness, o que pode ser entendido antes como amabilidade do que como amizade (friendship). 
intratável (duskolos) excedem por não se importarem em provocar dor ao outro ou, simplesmente, por não fazerem questão alguma de serem agradáveis. Como diz o filósofo: "quem excede, se não visa a nada, obsequioso, mas, se visa à sua própria vantagem, adulador; quem está em falta e é desagradável em tudo é um tipo quereloso e intratável” (1108a28-30). O amável ou afetuoso, por sua vez, sabe dar prazer e provocar dor ao outro na justa medida e pelas boas razões. Ele é como um "bom amigo", diferenciando-se deste por se comportar com a mesma propriedade com os estranhos. Isso significa que esta virtude não pode ser um tipo de amizade, apesar de se aproximar dela no aspecto do zelo ao outro, de querer verdadeiramente o bem do outro. ${ }^{20}$ Trata-se de "ter em mira o belo e o conveniente (sumpheron) para provocar a dor ou o prazer" (1126b29-31); por isso, os impulsos e os apetites direcionados ao outro devem se orientar pelo que é belo e conveniente e não pelo que é simplesmente prazeroso ou doloroso. Em suma, devemos agir e falar de modo agradável ou desagradável tendo em vista o que é belo ou conveniente e não o prazer ou a dor que será provocada no outro. Portanto, a pessoa amável jamais seria agradável por simplesmente agradar, e muito menos por interesse, como faz o bajulador. Quanto a si mesmo, a pessoa amável é capaz de recusar um prazer que seja desonesto, preferindo a dor; quanto ao outro, ela sempre terá em conta quem é ele, diferindo o seu tratamento conforme cada tipo de pessoa. Se causar alguma dor será em vista de um prazer futuro muito maior. Tampouco desejará dar prazer que cause injúria ou prejuízo a si mesmo, ainda que provoque alguma dor não excessiva; o que o distancia

20 A amizade, por sua vez, será examinada em toda a sua complexidade nos livros VIII e IX da Ética Nicomaqueia. Em VIII 1, Aristóteles afirma que a amizade "é uma certa virtude ou é acompanhada de virtude" (1155a2). Rackham (1892, p. 352) associa imediatamente esta virtude dita sem nome de IV 6 com a amizade de VIII e IX. Stewart, por sua vez, entende que este tipo de virtude se traduz por uma maneira agradável que causa simpatia nos encontros sociais, mas que deve se distinguir do fenômeno da amizade. Todavia, em EN II 7, Aristóteles parece se referir a esta virtude como sendo uma amizade (philia), o que induziu a associação feita por Rackham: "A respeito do agradável restante, o da vida, quem é agradável como se deve é amigo e a mediedade, amizade; quem excede, se não visa a nada, obsequioso, mas, se visa à sua própria vantagem, adulador; quem está em falta e é desagradável em tudo é um tipo quereloso e intratável” (1108a26-30). Todavia, linhas acima, em 1106b21, a philia aparece na lista das emoções (pathê), diferenciando-se, portanto, de uma disposição virtuosa. Em VIII 8, philêsis é um sentimento amigável, enquanto a philia será tratada como uma virtude. O termo philia, portanto, parece ser flutuante até chegarmos ao Tratado da amizade, por isso, acreditamos ser precipitado se referir a esta virtude deixada sem nome aqui no livro IV como sendo a amizade; mesmo porque o próprio filósofo diz expressamente que ela difere da amizade em 1126b23-24. 
da figura contemporânea do altruísta, pois ele não age apenas levando em conta o bem do outro, mesmo que para isso ele tenha que sofrer o que não deveria sofrer. Esta disposição não é senão ter os apetites e impulsos educados quando direcionados ao outro sem desconsiderar a si mesmo.

\section{A sinceridade}

Assim como a disposição em ser amável, esta disposição, examinada no livro IV, capítulo 7 (1127a12-b33), também não tem nome. O filósofo apenas nos diz que o seu objeto é a verdade (peri talêthes) no que diz respeito às palavras e ações nas relações sociais e que ela se localiza entre duas disposições extremadas, cuja característica é a mentira, a saber: uma em que a pessoa orgulhosamente atribui mais crédito a si mesmo do que deveria e outra que se autodeprecia indevidamente. Tendo em vista que aquele que encontra o meio termo é o homem sincero ou verdadeiro (alêtheutikos), sem hesitar, poderíamos denominar a disposição mediana de sinceridade. Mesmo porque, se no livro IV ele diz que ela é anônima, em II 7 é exatamente este nome que Aristóteles lhe atribui: "A respeito do que é verdadeiro, seja dito veraz quem está no meio termo e a mediedade, veracidade (alêtheia); a afetação para mais, presunção (alazoneia) e que a tem, presunçoso; a para menos, dissimulação (eirôneia) e quem a tem, dissimulado" (1108a20-22).

O orgulhoso ou presunçoso (alazôn) mente ao atribuir-se mais mérito do que devia, isto é, ele pretende ser reputado por aquilo que ele não é ou não tem, ou tem menos do que diz ter. Como diz nosso provérbio: "ele aumenta a verdade”. Já o dissimulado (eirôn), como ele se deprecia mais do que devia, negando ser ou ter as qualidades que lhe reputam, pode ser visto como um homem de falsa modéstia, ou como um pretensioso insolente ao desprezar todas as distinções recebidas. De qualquer forma, certamente ele é menos maléfico do que o tipo orgulhoso ao qual o homem sincero parece mais se opor. $\mathrm{O}$ orgulhoso mente para obter reputação ou lucro, pois coloca a reputação e o lucro acima da verdade. Ademais, ele sente prazer em dizer falsidades se esta for um meio para o reconhecimento. Por isso, o meio termo é o que conhecemos como ser sincero, transparente, franco ao se apresentar para os outros, mostrando-se tal como se é e dizendo com verdade o que se é. Veja que o objeto da sinceridade é bastante restrito e diz respeito a não angariar para si uma reputação maior ou menor daquela que é a sua verdadeira reputação por meio de discursos ou 
comportamentos. Por isso, Aristóteles diz explicitamente que esta virtude não concerne em ser verdadeiro em acordos feitos (homologiais), nem onde se exige ser justo, pois este será o objeto de outra virtude: a justiça (1127a33-b4).

Trata-se, portanto, de educar o apetite em ser verdadeiro e dizer verdades a respeito de si mesmo. A educação, como sabemos, não se faz com a imposição de imperativos morais, mas com a habituação. Por isso, como diz o filósofo: é preciso se tornar amante da verdade (philalêthês), isto é, é preciso aprender a ter prazer em ser sincero por ser sincero. Se assim nos habituarmos a recusar naturalmente falsidades a respeito de nós mesmos, ainda mais estaremos dispostos a recusar quando a falsidade for moralmente censurável.

\section{O bom-humor}

O relaxamento (anapausis) e a diversão (paidia) são necessários para a vida, afinal, não somos capazes de trabalhar sem intervalo. Em EN X 6, Aristóteles mostra que a diversão, que é um tipo de relaxamento, não deve ser concebida como o fim último da vida, mas não deixa ser necessária para a vida; mais precisamente, ela é um meio para a realização de uma atividade posterior e não um fim em si mesma (1176b30-1177a3). Por isso, nestes momentos de lazer, é preciso estar bem disposto para fruir de conversas e ações agradáveis, sabendo agradar e divertir na boa medida, sem ofender ou insultar. Esta disposição, examinada no livro IV, capítulo 8 (1127b34-1128b9), pode ser traduzida por bom-humor (eutrapelos), ${ }^{21}$ uma vez que o homem que assim se dispõe é bem-humorado na medida certa, ou seja, sabe ser sagaz, de bom tato (epidexios), pois tem tino para as boas piadas, sem perder a elegância própria ao homem gentil (eleutheriôi), nem a educação ao se divertir. Por outro lado, o excesso na diversão transforma-se em grosseria e ridicularização e é próprio ao tipo bufão (bômoloxos) e vulgar (phortikos), pois este tipo busca o riso a qualquer preço, mesmo que para tanto coloque a si mesmo em situações ridículas, ou seja ofensivo e constrangedor

21 Zingano traduz eutrapelos por espirituoso; Rackham e Ross por witty, que pode ser traduzido, em português, por agudeza de espírito. Nenhuma tradução é satisfatória, tampouco a que adotei, mas acredito que bom-humor pode bem caracterizar este tipo de boa disposição para as piadas e brincadeiras. Similarmente, Gauthier a traduz por enjouement, isto é, como nos fornece o dicionário Petit Robert, "disposition à la bonne humeur, à une gaieté aimable et souriante". Como disse Aristóteles na Retórica II 13: "os velhos gostam de se lamentar, por isso não são bem humorados (eutrapeloi) nem gostam de rir, pois gostar de se lamentar é o oposto de gostar de rir” (1390a21-23). 
com os outros. Já o extremo oposto caracteriza-se pelo mal-humorado (sklêros), que também pode ser considerado rude, mal-educado, antissocial (agroikos), enfim, este tipo é aquele sujeito intratável, incapaz de apreciar uma piada ou se deleitar com algo divertido. Enquanto o bufão busca, sem restrições, o prazer nas brincadeiras, o mal-humorado toma toda brincadeira como uma ofensa. Já o bem-humorado difere sobretudo do bufão ou do zombador por preferir a educação e a gentileza antes do que a piada, o que significa que ele não dirá palavras ofensivas ou fará brincadeiras abusivas para simplesmente se divertir. Como diz resumidamente Aristóteles: "Quanto ao agradável na diversão (peri to hêdu to en paidiâi), quem está no meio termo é bem-humorado e o estado, bom-humor; o excesso é a bufonaria e quem o tem, bufão; quem está em falta é um tipo rústico e a disposição, rusticidade” (EN II 7: 1108a24-26).

Ter bom-humor significa, portanto, gozar de prazeres em situações divertidas como se deve, colocando a educação e a gentileza acima de seu prazer em se divertir. Assim, podemos dizer que o bem-humorado terá o seu apetite educado para agir bem nessas situações.

\section{O pudor}

Já falamos do pudor (aidos) na exposição geral sobre as virtudes particulares e ressaltamos o fato de ele ser uma emoção e não uma virtude propriamente. Assim, no livro IV, capítulo 9 (1128b10-36), onde o pudor foi examinado ex professo, Aristóteles também afirma que ele é antes uma emoção (pathos) que uma disposição (hexis), ou seja, ele é um tipo de medo da desonra que se manifesta por sensações físicas. Não devemos desenvolver o pudor, ou seja, não se trata de passar a ser pudico ou envergonhado no processo de formação do caráter, pois o virtuoso, ao contrário, não deve sentir vergonha de suas belas e boas ações. O pudor é antes considerado algo bom enquanto a introjeção de um mecanismo de autocensura, por isso extremamente importante para os jovens. Ele é uma emoção que refreia o erro, uma vez que se deve ter vergonha de ser censurado ou desonrado. Sentimo-nos envergonhados quando somos censurados por alguém pelo que não deveríamos ter feito. Também podemos sentir vergonha de querer agir mal e de sermos posteriormente censurados por tal ato. Com efeito, esta internalização da censura pelo medo da desonra não é senão um meio de conter a si mesmo de modo a evitar a realização de uma ação vil. Ou seja, por evitar a dor futura da desonra, o jovem deixa de fazer ações vis 
e assim o apreço pela honra vai se instilando em seu caráter. ${ }^{22}$ Um adulto, por sua vez, que não seja virtuoso e que se controle por pudor será um adulto controlado (encratês). Este certamente não é um bom exemplo, pois nenhum adulto deveria ter de se controlar para não agir erradamente. Ninguém poderia ser dito verdadeiramente corajoso se sua ação for corajosa por medo da desonra e não por amor ao belo. $\mathrm{O}$ pudor, portanto, deve existir apenas no momento de formação do caráter, em que o jovem tem de refrear as suas ações vis por medo da desonra. De certo, essa emoção tem um caráter positivo apenas do ponto de vista pedagógico, pois, por constrangimento, o jovem é forçado a enfrentar certos medos, como no caso do corajoso, e agir bem. Em suma, ele é apenas um sentimento provisório que deve ser superado com a aquisição da virtude.

22 É preciso notar que o sentido primeiro de aidôs, presente em Homero, é aquele do sentimento de honra que, segundo Gauthier (2002, tome II, p. 320-324), parece se diferenciar do "aspecto negativo" presente na timidez e na autocensura necessárias aos jovens. Aristóteles, como vemos, enfatiza o aspecto negativo, que não deixa de ser provisoriamente positivo na formação do caráter. Contudo, quando o jovem age por medo da desonra, certamente ele está, no sentido inverso, cultivando o apreço pela honra, o que parece contemplar o aspecto positivo do pudor. Com efeito, em ENX 9, o aspecto positivo de pudor enquanto sentimento de honra parece estar nitidamente contemplado nas palavras do filósofo estagirita quando este diz que "a maioria é naturalmente mais suscetível ao medo do que ao sentimento de honra (aidôs), e abstém-se de coisas vis não por sua vileza, mas por causa das punições" (1179b11-12). 


\section{À guisa de conclusão}

À guisa de conclusão, podemos retomar, brevemente, os principais problemas e suas respectivas interpretações. Antes, porém, seria importante ressaltar que a questão principal deste livro, em torno da qual orbitam as demais, diz respeito, de modo geral, à educação do desejo e, mais especificamente, à constituição do bom fim.

Vimos que, para que o fim seja realmente um bem, ele deve ser fruto de uma apreensão racional própria do caráter virtuoso. Isso significa que o fim, objeto de nosso desejo, deve ser também objeto da reta razão (orthos logos), e que o bem concebido verdadeiramente pela razão deve ser também desejado enquanto fim da ação, isto é, deve ser também um bem aparente ou um bem tomado como tal pelo agente moral. Em outros termos, se o objeto natural do desejo é o prazer, com o processo educativo, ele passa a ser o bem verdadeiro independentemente de parecer prazeroso. Isso porque todo objeto se constitui enquanto objeto de desejo na medida em que se mostra sob a forma de um bem, e tomar algo como um bem ou um mal implica, comumente, considerar o prazer e a dor que acompanham ou que poderão acompanhar tal objeto.

Diante desta constatação, a pergunta que surge imediatamente é a seguinte: como podemos desejar a ação por ela ser boa e não por ela ser prazerosa, se desejá-la geralmente significa considerá-la prazerosa? Como podemos desejar o que julgamos ser bom em preferência do que o que percebemos ser prazeroso, uma vez que o bem e não o prazer deve ser o critério para a ação virtuosa? Enfim, como podemos desejar um fim concebido racionalmente? 
Para responder a esta pergunta, Aristóteles, primeiramente, reconhece que o prazer não pode ser o critério determinante da ação, já que ele não existe senão enquanto uma sensação que acompanha uma atividade (energeia). Logo, se o prazer existe apenas como uma espécie de epifenômeno à realização da atividade, então é a atividade que deve ser o objeto do desejo e é sobre ela que deve incidir o julgamento moral. Sendo assim, não é possível julgar se é bom ou não certo prazer, senão a partir do julgamento sobre a atividade acompanhada deste prazer. Ou seja, não há definição possível do valor moral do prazer senão a partir do valor atribuído à atividade. E se Aristóteles faz do julgamento que incide sobre a atividade (e não sobre o prazer) o critério avaliativo do prazer é porque tudo o que ele quer evitar é que tomemos o prazer e a dor como fundamentos do valor moral da ação. Por isso mesmo, a definição do prazer como aquilo que pertence a uma atividade que ele aperfeiçoa, nos permite inferir que o julgamento moral referente à atividade é o critério avaliativo do prazer, e não o contrário, o julgamento do que é prazeroso como critério avaliativo da atividade. Consequentemente, se o prazer não é critério para estabelecer que uma ação seja virtuosa, então o desejo deve aprender a se orientar não pelo que é indiscriminadamente prazeroso, mas antes pelo que determina a reta razão. Sobretudo os chamados desejos mais avessos à razão, o impulso (desejo de enfrentamento da dor) e o apetite (desejo pelo prazeroso), devem se orientar pelo que é belo e conveniente e não pelo que é simplesmente prazeroso ou doloroso, como constatamos na análise das virtudes particulares. Ou seja, o desejo deve aprender a desejar as atividades conforme o bom julgamento moral. Isso significa que devemos nos habituar a ter prazer e dor com o que se deve, como e quando se deve.

Assim, na primeira parte da tese "O prazer segundo Aristóteles", vimos que o desejo jamais poderia ser persuadido pela razão a ter bons objetos, se o prazer fosse considerado o mal ou o bem em absoluto. Se, por um lado, o prazer fosse o bem em absoluto, não haveria necessidade de se educar o desejo a ter prazer apenas com o que se deve, já que ele naturalmente deseja tudo o que é prazeroso e o que é prazeroso seria idêntico ao que é de fato bom. Todavia, o bem não pode ser reduzido ao que consideramos prazeroso. Ademais, o prazer não poderia ser o bem supremo, pois ele é causa necessária, mas não suficiente da felicidade. Por outro lado, se o prazer fosse o mal em absoluto, então jamais poderíamos ter prazer, portanto, apetite pelo que é bom; nem o prazer poderia ser considerado uma das causas da felicidade. Ora, como poderíamos desejar ser virtuosos e felizes, se o nosso desejo estivesse, em grande medida, 
fadado a desejar coisas ruins? Se tudo o que desse prazer também fosse condenável, então tudo o que pudéssemos ter apetite também o seria. Neste caso, o apetite jamais teria como objeto um bem, o que implica dizer que a aquisição da temperança deveria ser considerada impossível. Se nenhum prazer pudesse, por princípio, ser bom, então seria impossível educar o desejo a ter prazer com o que é bom. Seria também inútil educar o desejo se sua natureza não fosse educável, ou seja, se ele não pudesse ter como objeto o que é correto, bom, saudável. O projeto da educação do desejo, por conseguinte, da aquisição da virtude, frente ao anti-hedonismo ou ao hedonismo extremo, estaria fadado ao fracasso e já não poderíamos conceber a ética aristotélica como uma ética das virtudes.

Não parece ser aleatório e, mais do que isso, parece mesmo ser um ganho conceitual diante de seus precedentes, o fato de Aristóteles ter defendido uma tese hedonista moderada, em que o prazer, embora não seja $o$ bem, possa ser um bem, uma vez que esteja acompanhando a realização de uma boa atividade. Enfim, como podemos constatar, é preciso que o prazer possa ser considerado um bem, pois tanto a felicidade, como a virtude são bens e são coisas naturalmente prazerosas. Por isso, o fundamento da educação moral se encontra no fato de que a nossa natureza é educável e de que nós podemos aprender a ter bons prazeres. Em suma, com a análise dos dois Tratados do prazer, concluímos que todo esforço de Aristóteles consiste em defender a possibilidade de o prazer ser um bem, e assim se posicionar por um hedonismo moderado diante do radicalismo anti-hedonista, por um lado, e hedonista, por outro.

Com efeito, vimos que, no primeiro Tratado, Aristóteles se aproxima do hedonismo de Eudoxo com vistas a refutar o anti-hedonismo de Platão e de Espeusipo. Com essa estratégia refutativa, a única tese propositiva que ele formula é a de que o prazer pode ser um bem. Já no segundo Tratado, Aristóteles se dedica a sustentar um hedonismo moderado, distanciando-se do radicalismo hedonista de Eudoxo, ao mostrar que ele é, em parte, falso e, em parte, verdadeiro. A pergunta do primeiro Tratado é a de que se o prazer pode ser um bem ou deveria ser considerado o mal em absoluto. Visto que o prazer é definido, no primeiro Tratado, como um bem por ser uma atividade desimpedida, a pergunta do segundo Tratado é a de que se o prazer poderia ser o bem em absoluto, isto é, a felicidade, pois esta também é uma atividade desimpedida. A reelaboração da definição de prazer, no segundo Tratado, nega a assimilação do prazer à felicidade, pois ele deixa de ser simplesmente uma atividade e passa a ser um efeito que sobrevém à realização da atividade à qual pertence. Enfim, o ganho conceitual desta 
nova definição é que o prazer não deve ser considerado nem bom nem mau nele mesmo, mas, por acompanhar uma atividade boa ou má, ele pode ser bom ou mau. Não há, portanto, uma concepção essencialista do valor moral do prazer. Afinal, como a sua existência e essência dependem absolutamente da atividade à qual ele acompanha, é possível sustentar que a qualidade moral do prazer depende da qualidade moral desta atividade e o valor atribuído a esta atividade, por sua vez, depende do bom julgamento do homem virtuoso.

Ao terminarmos a primeira parte do livro, concluímos que a concepção aristotélica de prazer permite que o desejo, sobretudo o apetite, possa ser educado. Entretanto, não basta sabermos que o desejo pode ter prazer com o que é bom, é preciso compreender, por um lado, como ele pode passar a ter como objeto aquilo mesmo que a razão apreende como um bem e, por outro, como a razão pode atuar sobre o desejo. Mais precisamente, que operação racional atua sobre o desejo no processo formativo do caráter e na constituição do fim da ação. Em suma, na segunda parte do livro, "O desejo segundo Aristóteles", passamos a investigar como a educação do desejo se realiza.

A pergunta sobre como a razão pode atuar no desejo com vistas a constituir o fim virtuoso implica determinarmos quais funções racionais são estas e como elas atuam. Vimos que Aristóteles claramente descarta a função contemplativa (theôrêtikos) ou científica (epistêmonikon), responsável por contemplar os princípios invariáveis do ser. Isso porque a função racional determinante na produção da ação deve ser prática, portanto, distinta da contemplativa. Aristóteles nos diz que esta função prática é essencialmente calculativa (logistikon), pois é capaz de calcular (logizesthai) e deliberar (bouleuesthai) os fatores variáveis e circunstanciais envolvidos na ação de modo a determinar o que deve ser feito.

Todavia, como vimos, a racionalidade prática, mesmo tendo a sua expressão máxima na função deliberativa, não poderia estar reduzida a ela, pois a deliberação é responsável exclusivamente pela apreensão dos meios e não do fim. Se assim estivesse reduzida, o problema da constituição racional do bom fim seria definitivamente aporético. Em poucas palavras, o problema consiste em esclarecer o seguinte ponto obscuro: a razão deve educar o desejo a ponto de poder participar na constituição do fim da ação, mesmo que não seja através de sua função deliberativa. A necessidade de a razão ser eminentemente ativa na formação do caráter e na constituição do fim desejado é evidente; o que, porém, não é assim tão transparente é saber qual tipo de função racional pode atuar em conformidade ao desejo. 
Evidentemente, para solucionarmos esta dificuldade, devemos supor a existência de uma outra função racional, distinta da investigação deliberativa, que atue na constituição do objeto de desejo. A título de diferenciação da função deliberativa, chamamo-la, faute de mieux, de persuasiva. Apesar de o filósofo não a ter nomeado, ele a pressupõe e a descreve como uma certa visão do fim virtuoso. Vimos que Aristóteles parte do pressuposto de que o virtuoso vê (horan) o que é bom a ser feito e vê corretamente (horosin orthos). Dizer isto nada mais é do que dizer que o desejo põe (tithênai) o fim apreendido pela reta razão em sua função persuasiva e não deliberativa, uma vez que fora persuadido por ela. Dispor um fim, em termos gerais, significa perceber o que é preciso ser feito diante das circunstâncias que se apresentam e persuadir o desejo a desejar isto mesmo que fora percebido.

Neste sentido, seria falso atribuir ao filósofo o conceito de vontade na tentativa de solucionar este problema. A vontade, como vimos, pressupõe que o querer (boulêsis) seja um desejo absolutamente racional ou que a razão possa ser ela mesma capaz de desejar o fim por ela concebido. Aparentemente, o conceito de vontade soluciona esta dificuldade, como procuraram mostrar alguns filósofos medievais e modernos, mas esta não é e nem poderia ser a solução de Aristóteles. Assim, pretendemos mostrar como é equivocada a interpretação que lhe atribui tal conceito. Ademais, a riqueza da ética aristotélica encontra-se justamente em outra solução que não naquela proposta pelo conceito de vontade.

Se não é adequado delegar a Aristóteles o papel de fundador do conceito de vontade, embora a sua concepção de escolha deliberada (prohairesis), conjugada ao querer (boulêsis), incite tal interpretação, verificamos que outra solução a este dilema é possível. Para tanto, foi preciso investigar os tipos de funções racionais e como elas podem atuar na determinação do fim. Podemos dizer, grosso modo, que haveria duas funções racionais propriamente práticas: a deliberativa, que concerne aos meios, e a persuasiva, que concerne aos fins, isto é, que educa e persuade o desejo a tomar como seu objeto o que fora determinado corretamente como sendo bom.

A função deliberativa é responsável pela apreensão dos meios e, no caso do homem bom, pelos bons meios e pela avaliação moral do fim; portanto, ela não atua direta e imediatamente sobre o desejo, visto que não podemos escolher o que iremos desejar, mas se iremos realizar ou não o que já desejamos. Vimos que a constituição do fim desejado antecede à deliberação e, portanto, à escolha deliberada. Isso significa que ele não é fruto de uma escolha, mas, ao contrário, 
a escolha tem como causa o fim desejado; pois a escolha é um desejo deliberado pelos meios capazes de realizar certo fim. A escolha, portanto, é o desejo oriundo da investigação deliberativa, cujo objeto é um meio realizável aqui e agora em vista de um fim já dado. Quanto ao fim propriamente, a escolha não o constitui, mas apenas o aprova ou não.

É possível reconhecer um tipo de função racional exterior ao agente durante o processo de formação do caráter. No processo formativo, vimos que a razão que atua na educação dos desejos da criança lhe é exterior, portanto, pode ser compreendida como uma racionalidade presente nos conselhos, censuras e elogios dos adultos. Basicamente, a educação moral dos desejos significa educar a criança a ter prazer e dor com o que se deve. Esta trajetória pode ser descrita do seguinte modo: ao mesmo tempo em que a criança vai sendo orientada pela autoridade exterior, ela vai gradualmente aprendendo a discriminar o certo do errado e assim vai criando uma espécie de sensibilidade moral e se tornando capaz de tomar decisões por conta própria. Assim sendo, podemos concluir que a educação moral é justamente a realização da passagem entre o agir virtuosamente sem ser virtuoso ao agir virtuosamente sendo virtuoso; da passagem do agir por autoridade exterior ao agir por decisão própria desejando o fim virtuoso em vista dele mesmo.

Uma vez de posse da razão, o agente pode corrigir o seu caráter através da mudança de hábito, o que implica conhecimento de si. Isso porque, nos casos em que a razão ainda não foi inteiramente corrompida, o agente pode procurar corrigir seus próprios defeitos e aperfeiçoar seu caráter através do "autoconhecimento" e da "cura pelo contrário". Conhecendo a si mesmo e adquirindo bons hábitos, o adulto pode educar seus próprios desejos e corrigir suas próprias tendências e propensões, de modo a atingir a disposição mediana. Neste caso, o modo de atuação da razão parece ser primordialmente avaliativo e controlador.

A função persuasiva da razão, portanto, atua tanto de modo indireto na constituição do fim, na medida em que é responsável pela aquisição das disposições morais, como de maneira direta, na medida em que é capaz de persuadir o desejo a desejar o que ela apreendeu como sendo bom. Podemos inferir que a razão, por meio da determinação da ação, atua indiretamente sobre o desejo, portanto, sobre o fim da ação e, por meio da persuasão, atua diretamente sobre o desejo, portanto, na determinação do fim da ação.

A atuação direta da razão sobre o objeto de desejo, por sua vez, está condicionada à educação prévia dos desejos, portanto, à atuação da razão na formação 
do caráter virtuoso. Sabemos que, para que a razão possa apreender verdadeiramente o que deve ser feito, ela precisa estar em harmonia com o desejo, ou seja, a correta apreensão racional do fim pressupõe a existência de uma disposição em desejar o que é bom. Isso significa que, como pretendemos ter mostrado, há precedência da educação do desejo ao bom uso da racionalidade no âmbito das ações e emoções. Em poucas palavras, é preciso estar afetivamente predisposto para que a nossa razão possa perceber a melhor ação a ser realizada em dada situação particular. Para ver o que é bom a ser feito é preciso querer ver desse modo.

Procuramos mostrar a evidente imbricação entre desejo e razão, na medida em que a razão depende de um desejo educado para que ela possa exercer sua persuasão de modo adequado, e o desejo depende da razão para que ele possa ser educado e, consequentemente, possa ter como objeto o que é bom de fato. Por isso, foi imprescindível discriminar os modos de atuação da razão na formação do caráter, bem como na constituição do fim da ação.

A análise da atuação da razão durante e posteriormente à formação do caráter virtuoso nos permitiu sustentar a tese da precedência da educação dos desejos à aquisição plena da virtude. Argumentamos que, mesmo que a razão seja naturalmente capaz de julgar o que é bom, a educação prévia dos desejos é necessária para que esse correto julgamento ocorra. Ou seja, é preciso primeiramente se habituar a desejar o que é moralmente bom para que a razão possa estar apta a apreender o que é realmente bom e o agente possa passar de um estado de formação do caráter para um estado em que se é propriamente virtuoso. Por isso, somente alguém que já seja virtuoso poderá conceber por si mesmo a ação virtuosa e dar as boas razões para tanto. Alguém que esteja em processo de aquisição da virtude, por sua vez, dependerá fortemente dos conselhos para orientar suas ações, pois que sua racionalidade não adquiriu a autonomia prática própria do homem com o caráter já constituído.

Uma vez constituído o caráter, a razão que antes era externa ao agente, passa a estar sob o seu domínio. Esta racionalidade prática própria ao agente moral já adulto possui, ao menos, duas funções essenciais: uma responsável pela apreensão dos meios, a deliberativa, e outra responsável pela apreensão do fim. O virtuoso é aquele que faz uso maximamente da racionalidade prática em ambas as funções, pois ele apreende verdadeiramente tanto o bom fim e persuade o desejo a desejá-lo, como os bons meios.

Chegamos assim ao seguinte ponto da investigação: vimos que a educação do desejo é necessária, restando-nos ainda compreender como ela é possível e, 
sendo possível, como ela se realiza. Em primeiro lugar, quanto à sua possibilidade, já sabemos que a alma humana é constituída de modo que a razão pode participar perfeitamente do desejo persuadindo-o. Todavia, não basta compreender que o desejo possa desejar o fim virtuoso, é preciso investigar como é possível que ele venha a desejá-lo. Neste sentido, em segundo lugar, precisamos ter em mente que a natureza de nossa alma, segundo Aristóteles, viabiliza a educação dos desejos através da participação da razão na parte desiderativa. Ou seja, a alma está estruturada de tal modo que a faculdade desiderativa é híbrida entre a faculdade intelectiva e a vegetativa, entre a posse e a ausência de razão, pois ela é um movimento que provém da parte não racional, mas que, ao mesmo tempo, pode participar da parte racional. Por isso, em alguma medida, a razão deve ser capaz de participar do desejo, e este deve ser capaz de participar da razão. Esta possível comunicação entre desejo e razão nos fornece a condição de possibilidade do desejo ser educado.

Posta a possibilidade, segue-se a pergunta sobre como ele é educado. Para que o desejo seja educado, é preciso haver uma racionalidade capaz de educá-lo. A educação do desejo deve ser compreendida como o processo de formação do caráter, de aquisição da virtude através do habito em desejar o que é bom segundo o julgamento correto. Isso porque é o julgamento correto, aquele tal qual faria o virtuoso (spoudaios), que determina o que é bom (agathos) e belo (kalos). O bom e belo, por sua vez, são também ações prazerosas em si mesmas e para aquele que os deseja em vista deles mesmos. Assim, a operação desiderativa ideal é justamente aquela do homem bom, ou seja, aquela daquele que sabe encontrar a sua felicidade e prazer no que é propriamente virtuoso, pois já habituou o seu desejo a ser conforme a reta razão.

Isso significa que, ao ter educado seus desejos, o homem virtuoso passa a desejar e a achar prazeroso o que é bom segundo o julgamento correto. Por isso, o que ele julga ser bom lhe aparece como prazeroso. Já para o vicioso, ao contrário, o que lhe aparece como prazeroso é o que ele julga ser bom. Em suma, o homem bom é o padrão (kanon) e a medida (metron) para o que é prazeroso e penoso. Por isso, o que é considerado prazeroso para o homem bom também é prazeroso por natureza. O que é penoso para o homem bom, mas prazeroso para alguns, assim o é por corrupções (phthorai) ou por doenças (lumai). Desse modo, o vicioso sente prazer com o que não é naturalmente prazeroso, todavia não deixa de ter prazer, mesmo que este seja excessivo e contrário à natureza. 
Em outros termos, educar o desejo não é senão tornar-se moralmente virtuoso. Como o desejo é naturalmente a busca indiscriminada por prazer e a recusa de qualquer dor, educar o desejo significa, sobretudo, educar a ouvir a razão e a ter prazer e dor com o que se deve. O desejo, uma vez educado, passa a ter como objeto o bem apreendido, na particularidade da ação, pela razão. Assim, o desejo educado é aquele cujo objeto particular realizável aqui e agora também é uma expressão do desejo pelo fim último, isto é, pela felicidade. O desejo não educado, por sua vez, é próprio das crianças e dos animais, bem como dos adultos que vivem cegamente segundo os seus afetos, sem ter ideia do que é belo e verdadeiramente prazeroso, ou seja, são aqueles que visam o prazer de modo insaciável e indiscriminado: os adultos viciosos, como o perverso (kakos) e o intemperante (akolastos), e aqueles que ainda não são propriamente virtuosos nem viciosos, como os controlados (acrático) e os descontrolados (encratês).

Ao contrário das figuras morais do fracasso, o virtuoso se encontra numa harmonia tal que o que a razão vê como sendo o melhor, o desejo deseja. Em suma, a educação moral parece ser condição simultânea da apreensão racional verdadeira do bem e do desejo que a toma como objeto, ou seja, o virtuoso vê e imediatamente é persuadido a desejar o que deve ser feito. E assim o faz porque está previamente disposto a fazê-lo. Em outros termos, a educação do desejo é condição para que a razão seja capaz de apreender verdadeiramente o bom fim. E verdadeiramente quer dizer não apenas ver o que deve ser feito (isto o vicioso e o descontrolado também são capazes), mas persuadir o desejo a ter prazer com o que é correto, isto é, ver verdadeiramente significa apreender como bom e também prazeroso isto que deve ser feito.

Enfim, se para Aristóteles a habituação é o meio pelo qual a virtude pode ser adquirida, certamente ela não poderia ser uma dádiva divina ou natural, nem, como queria Sócrates, fruto de ensinamento. Vimos que a ética aristotélica, em oposição às posições intelectualista e naturalista, não pressupõe que a razão seja autônoma o suficiente para determinar o fim da ação segundo o conhecimento do bem e do mal, nem que ele seja dado por uma natureza inata boa ou má, porém pressupõe que apenas a razão seja capaz de apreender o que é verdadeiramente bom.

É bem sabido que o clássico problema do alcance e do limite do conhecimento na determinação da ação moral já é objeto de disputa entre Aristóteles e Sócrates. Diante do projeto socrático intelectualista, para o qual o conhecimento do bem é causa suficiente da ação virtuosa, Aristóteles, com a sua concepção 
da aquisição da virtude por hábito, limita o papel do conhecimento ao pressupor que a determinação da ação depende essencialmente de um elemento não racional, a saber: o desejo. Afinal, a finalidade de nossas ações é justamente o que desejamos. Entretanto, como o conhecimento do bem não poderia ser causa suficiente, mas apenas necessária da ação, um dos problemas centrais da ética aristotélica consiste em delimitar em que medida razão e desejo, saber o que é bom e querer o que é bom, são causas da ação. Por isso, tendo em vista que a determinação da boa ação depende essencialmente que a sua finalidade seja boa, o objeto de nossa investigação foi o problema da constituição do fim, cuja apreensão correta pressupõe a aquisição da virtude moral e se traduz na bela harmonia entre razão e desejo.

Podemos concluir este livro dizendo que a solução aristotélica para o problema da constituição racional do fim virtuoso não se resolve com o conceito de vontade, mas com o que podemos entender por razão persuasiva. A razão é capaz de discriminar corretamente as circunstâncias particulares de modo a encontrar o meio termo a ser desejado e almejado na ação. Esta retitude discriminativa, esta justeza e agudeza na razão somente podem ocorrer naquele que está previamente preparado em termos afetivos, isto é, que seja afetivamente capaz de ver o melhor. Ou seja, o bom uso da razão na apreensão do fim está condicionado ao bem-estar afetivo próprio do caráter virtuoso. Trata-se, antes, de ser afetivamente capaz de julgar o que é de fato bom do que de ser racional o suficiente para dominar os afetos. Em outras palavras, é preciso haver engajamento afetivo para que a ação seja propriamente correta. A razão só vê o que é certo porque estamos afetivamente propensos a ver, porque queremos ver assim. Os afetos, ao se constituírem como disposições, atuam como certos padrões ou regularidades; e estas nada mais são do que modos de raciocinar e perceber. Mais do que o conhecimento sobre o bem, são os afetos que condicionam a percepção do que é moralmente relevante; dentre eles, a voz pungente é a do desejo. 


\section{Referências}

\section{Bibliografia central}

ARISTÓTELES. Aristotle: metaphysics Books 4, 5 e 6. Tradução de Christopher Kirwan. Oxford: Oxford University Press, 2003a.

ARISTÓTELES. Aristotle: Nichomachean Ethics. Tradução de Christopher Rowe. Oxford: Oxford University Press, 2002a.

ARISTÓTELES. Aristotle De Anima. Tradução de W. Ross. Oxford: Oxford University Press, 1961.

ARISTÓTELES. De Anima. Tradução de R. D. Hicks. New York: Georg Olms Verlag, 1990.

ARISTÓTELES. De l’Ame. Tradução de R. Bodéüs. Paris: GF-Flamarion, 1993.

ARISTÓTELES. Ética a Nicómaco. Tradução de María Araujo e Julián Marías. Madrid: Centro de Estudios Políticos y Constitucionales, 2002b.

ARISTÓTELES. Retórica. Tradução de Paulo Farmhouse e Alberto e Abel do Nascimento Pena. São Paulo: Martins Fontes, 2012.

ARISTÓTELES. A retórica das paixões. Tradução de Isis Fonseca. São Paulo: Martins Fontes, 2003b.

ARISTÓTELES. Rhétorique. Tradução de Pierre Chiron. Paris: Flammarion, 2007.

ARISTÓTELES. Nichomachean Ethics. Tradução de Terence Irwin. Indianapolis: Hackett Publishing, 1999.

ARISTÓTELES. On the Soul, Parva Naturalia, On Breath. Tradução de W. Hett. Cambridge: Havard University Press, 1936. 
ARISTÓTELES. Opera ex recensione I. Bekker. Berlin: Academia Regia Borussica, 1831 [1960].

ARISTÓTELES. Sobre a Alma. Tradução de Ana Maria Lóio. São Paulo: Martins Fontes, 2013.

ARISTÓTELES. Works of Aristotle. In: ROSS, W. D. (Org.). The Great Books. Oxford: University Press, 1980.

ARISTÓTELES. The nichomachean ethics. Tradução de Rackham. Havard: Loeb Classical Library, 1962.

HOMERO. Ilíada. Traduçaõ de Frederico Lourenço. Lisboa: Livros Cotovias, 2005.

PLATÃO. A República. São Paulo: Martins Fontes, 2006.

PLATÃO. The Dialogues of Plato. In: JOWETT, B. (Org.). The Great Books. Oxford:

Encyclopedia Britannica, 1952.

PLATÃO. Republic. Tradução de Paul Shorey. Cambridge: Harvard University Press, 1930.

\section{Bibliografia complementar}

ACKRILL, J. L. Aristotle's Ethics. London: Faber \& Faber, 1973.

ACKRILL, J. L. Energeia and Kinêsis. In: ACKRILL, J. L. Essays on Plato and Aristotle. Oxford: Clarendon Press, 1997.

AGGIO, J. O. Conhecimento perceptivo segundo Aristóteles. 2006. 118 f. Dissertação (Mestrado em Filosofia) - Faculdade de Filosofia, Letras e Ciências Humanas, Universidade de São Paulo, São Paulo, 2006.

ALEXANDRE OF APHRODISIAS. Ethical Problems. Tradução de Sharples. New York: Cornell University Press, 1990.

ALLAN, D. J. Aristotle's account of the origin of moral principles. In: BARNES, J.;

SCHOFIELD, M.; SORABJI, R. Articles on Aristotle: Ethics and Politics. London: Duckworth, 1977.

ANNA, J. Aristotle on Pleasure and Goodness. Em: RORTY, A. O. Essays on Aristotle's Ethics. California: University of California Press, 1980.

AQUINO, T. de. Commentary on Aristotle's Nicomachean Ethics. Notre Dame: Dumb Ox Books, 1993.

ASPÁSIO: On Aristotle Nichomachean Ethics, 1-4, 7-8. Londres: Duckworth, 2006. [150, $18-24]$.

AUBENQUE, P. Logos et pathos. Pour une définition dialectique des passion (De Anima I 1 et Rhétorique II). In: VIANO, C.; DHERBEY, R. Corps et Ame. Paris: Librairie Philosophique, 1996. 
AUBENQUE, P. A prudência em Aristóteles. São Paulo: Discurso editorial, 2008.

AUBENQUE, P. La Prudence chez Aristotle. Paris: Presses Universitaires de France, 1963.

AUBENQUE, P. La Prudence aristotélicienne, porte-t-elle sur la fin ou sur les moyens? Revue des Études Grecques, Paris, v. 78, n. 369, p. 40-51, 1965.

AUBRY, G. Nicomachean Ethics VII 14, (1154a22-b34): The Pain of the Living and Divine Pleasure. In: NATALI, C. (Ed.). Aristotle: Nicomachean Ethics, Book VII - Symposium Aristotelicum. Oxford: Oxford University Press, 2005. p. 237-263.

BARNES, J. The Cambridge Companion to Aristotle. Cambridge, Cambridge University Press, 1995.

BARNES, J.; SCHOFIELD, M.; SORABJI, R. Articles on Aristotle: Ethics and Politics. London: Duckworth, 1977.

BARNES, J.; SCHOFIELD, M.; SORABJI, R. Articles on Aristotle: Psychology and Aesthetics. London: Duckworth, 1979. v. 4.

BERNARDETE, S. Aristotle De Anima III 3-5. Review of Metaphysics, [S.l.], v. 28, n. 4, p. 611$622,1975$.

BLOOM, P. How Pleasure Works: The new science of why we like what we like. New York: Norton, 2010.

BOSTOCK, D. Aristotle's ethics. Oxford: Oxford University Press, 2006.

BURNYEAT, M. F. Aprender a ser bom segundo Aristóteles. In: ZINGANO, M. (Org.). Sobre a Ética Nicomaqueia de Aristóteles. São Paulo: Odysseus, 2010. p. 155-182.

BURNYEAT, M. F. De Anima II 5. Phronêsis, Netherlands, v. 47, n. 1, p. 28-90, 2002.

BURNET, J. The Ethics of Aristotle. London: Methuen, 1900.

BRENTANO, F. Descriptive Psychology. Tradução de Benito Mueller. London: Routledge, 1995.

BRENTANO, F. Psychology from an Empirical Standpoint. London: Routledge and Kegan Paul, 1975.

BRENTANO, F. The Origin of Moral Knowledge. [S.l.]: Grupo Anaya Comercial, 2005.

BROADIE, S. Ethics with Aristotle. Oxford: Oxford University Press, 1993.

BROADIE, S.; ROWE, C. Aristotle, Nicomachean Ethics: Translation, Introduction, and Commentary. Oxford, Oxford University Press, 2002.

CANTO-SPERBER, M. Le rôle de l'imagination dans la philosophie aristotélicienne de l'action. In: VIANO, C.; DHERBEY, R. Corps et Ame. Paris: Librairie Philosophique, 1996.

CASTON, V. Aristotle and the problem of Intentionality. Philosophy and Phenomenological Research, Buffalo, v. 58, n. 2, p. 249-298, June 1998.

CASTON, V. Why Aristotle needs imagination. Phronêsis, Netherlands, n. 41, p. 20-55, 1996. 
CASTORIADIS, C. La découverte de l'imagination. Libre, Paris, n. 3. p. 151-189, 1978.

CHARLES, D. Aristotle's Philosophy of Action. Ithaca: Cornell University Press, 1984.

CHARLES, D. Aristotle: Ontology and Moral Reasoning. In: OXFORD Studies in Ancient Philosophy. Oxford: Clarendon Press, 1986. v. 4.

CHARLES, D. Aristotle's Desire. In: HIRVONEN, V.; HOLOPAINEN, T. J.; TUOMINEN, M. (Ed.). Mind and Modality: Essays in Honour of Simo Knuuttila. Leiden: Brill, 2006. p. $19-40$.

COOPER, J. Knowledge, Nature and the Good. Princeton: Princeton University Press, 2004.

COOPER, J. Reason and Human Good in Aristotle. Cambridge: Harvard University Press, 1975.

COOPER, J. Reason and Emotion. Princeton: Princeton University Press, 1999.

COOPER, J. Reason, Moral Virtue, and Moral Value. In: FREDE, M.; STRIKE, G. Rationality in Greek Thought. Oxford: Clarendon Press,1997. p. 81-114.

COOPER, J. Some remarks on Aristotle's Moral Psychology, Southern Journal of Philosophy, [s. 1.], v. 27, n. S2, p. 25-42, 1988. Suplemento.

CORDERO, N. L. Ontologie et dialogue: mélanges en hommage à Pierre Aubenque. Paris: Vrin, 2000.

FERTENBAUGH, W. Aristotle on Emotion. London: Duckworth, 1975.

FESTUGIÈRE, A. J. Aristote: Le plaisir. Paris: J. Vrin, 1946.

FIELD, H. Mental Representation. Erkenntnis, Dordrecht, v. 13, n. 1, p. 9-61, 1978.

FORTENBAUGH, W. Aristotle’s Pratical Side. Boston: Ed. Brill, 2006.

FREDE, D. Nicomachean Ethics VII 11-12: Pleasure. In: NATALI, C. (Ed.). Aristotle:

Nicomachean Ethics, Book VII - Symposium Aristotelicum. Oxford: Oxford University Press, 2005. p. 183-207.

FREDE, D. Prazer e dor na ética aristotélica. In: KRAUT, R. Aristóteles: A ética a Nicômaco. Rio Grande do Sul: Artmed, 2009. p. 236-253.

FRÈRE, J. Emportement et colère: thumos et orgè selon Aristote. In: CORDEIRO, N. L. Ontologie et Dialogue. Paris: J. Vrin, 2000.

GAUTHIER, R. A. La morale d'Aristotle. Paris: Presses universitaires de France, 1963.

GAUTHIER, R. A. L'Éthique à Nicomaque. Paris: Peeters, 2002. Tomos I e II.

GOSLING, J. C. B.; TAYLOR, C.C.W. The Greeks on Pleasure. Oxford: Clarendon Press, 1982.

GREENWOOD, L. H. G. Aristotle, Nicomachean Ethics Book VI. New York: Arno Press, 1973. 
GRÖNROOS, C. Listening to reason in Aristotle's Moral Psychology. In: SEDLEY, D.

Oxford Studies in Ancient Philosophy. Oxford: Oxford University Press, 2007. v. 32, p. 251-271.

HARDIE, W. F. R. Aristotle's Ethical Theory. Oxford: Clarendon Press, 1968.

HOBUSS, J. Ética das Virtudes. Florianópolis: Ed. da UFSC, 2011.

IRWIN, T. Aristotelian Actions, Phronêsis, Netherlands, v. 31, n. 1, p. 68-89. 1986.

IRWIN, T. The Development of Ethics. Oxford: University Press, 2007. v. I.

IRWIN, T. Who dicovered the will? Philosophical Perspectives, Malden, v. 6, p. 453-473, 1992.

JACKSON, R. Rationalism and intellectualism the Ethics of Aristotle. Mind, Oxford, v. 51, p. 343-60, 1942.

JOACHIM, H. Aristotle, The Nicomachean Ethics. Oxford: Clarendon Press, 1951.

KENNY, A. Action, Emotion and Will. London: Routledge \& Kegan Paul,1963.

KENNY, A. The Aristotelian Ethics. Oxford: Clarendon Press, 1978.

KRAUT, R. Aristóteles: a ética a Nicômaco. São Paulo: Artmed, 2009.

LABARRIÈRE, J.-L. Imagination Humaine et imagination animale chez Aristote. Phronêsis, Netherlands, v. 29, n. 1, p. 17-49, 1984.

LEAR, J. Aristóteles: o desejo de entender. São Paulo: Discurso editorial, 2006.

LEAR, J. Integrating the non-rational soul. Proceedings of the Aristotelian Society, London, v. 114, n. 1, p. 75-101, 2014.

LEBRUN, G. O conceito de paixão. In: NOVAES, A. Os sentidos da paixão. São Paulo: Companhia das Letras, 2002.

LORENZ, H. The Brute Within: Appetitive Desire in Plato and Aristotle. Oxford: Clarendon Press, 2006.

MARINHEIRO, V. Crenças e preconceitos moldam reação das pessoas a prazer e dor. Folha de São Paulo, São Paulo, 19 jul. 2011. Entrevista de Paul Bloom.

MAY, H. Aristotle's Ethics: Moral Development and Human Nature. New York: Continuum International Publishing Group, 2010.

MODRAK, D. Aisthesis in practical syllogism. Philosophical Studies, Dordrecht, v. 30, n. 6, p. 379-391, 1976.

MOREL, P. M. De la matière à l'action: Aristote et le problème du vivant. Paris: J. Vrin, 2007.

MOREL, P. M. L'habitude: une seconde nature? In: MOREL, P. M. Aristote et la notion de nature. Bordeaux: Presses Universitaires de Bordeaux, 1997. p. 131-148.

MOSS, J. Virtue Makes the Goal Right: Virtue and Phronêsis in Aristotle's Ethics. Phronêsis, Netherlands, v. 56, p. 204-261, 2011. 
MOSS, J. Aristotle on the apparent good: Perception, Phantasia, Thought, and Desire. Oxford: Oxford University Press, 2012.

MOURA, C. A. R. A indiferença e a balança. In: ZINGANO, M. (Org.). Lógica e ontologia: ensaios em homenagem a Balthazar Barbosa Filho. São Paulo: Discurso editorial, 2004.

MUZIO, G. Aristotle on improving one's character. Phronêsis, Netherlands, v. 45, n. 3, p. 205$219,2000$.

NATALI, C. Particular Virtues in the Nicomachean Ethics of Aristotle. In: SHARPLES, R. W. Particulars in Greek Philosophy. Leiden: Brill, 2010.

NUSSBAUM, M. Aristotle's De Motu Animalium. New Jersey: Princeton University Press, 1985.

NUSSBAUM, M. The 'Common Explanation' of Anima Motion. In: MORAUX, P.;WIESNER, J. Symposium Aristotelicum. Berlim: Walter de Gruyter, 1983. p. 116-156.

NUSSBAUM, M.; RORTY, A. (Ed.). Essays on Aristotle's De Anima. Oxford: Oxford University Press, 1992.

NUSSBAUM, M. The role of phantasia in Aristotle's Explanation of Action. In: NUSSBAUM, M. Essay 5 of Aristotle's De motu animalium. New Jersey: Princeton University Press, 1978. p. 221-269.

OWEN, G. E. L. Aristotelian Pleasures. In: BARNES, J.; CHOFIELD, M.; SORABJI, R. Articles on Aristotle: Ethics and Politics. London: Duckworth, 1977.

OWEN, G. E. L. Logic, Science and Dialetic: Collected Papers in Greek Philosophy. Ithaca: Cornell University Press, 1986.

OWEN, G. E. L. Prazeres Aristotélicos. In: ZINGANO, M. (Org.). Sobre a Ética Nicomaqueia de Aristóteles. São Paulo: Odysseus, 2010.

PAKALUK, M. Aristotle's Nicomachean ethics: an introduction. Cambridge: Cambridge Univ. Press, 2008.

PAKALUK, M.; PEARSON, G. Moral Psychology and Human Action in Aristotle. Oxford: Oxford Univ. Press, 2011.

PHILIPPE, M. D. Phantasia in the Philosophy of Aristotle. Thomist, Washington, v. 35, n. 1, p. 1-42, 1971.

RAPP, C. Nicomachean Ethics VII 13-14 (1154a21): Pleasure and eudaimonia. In: NATALI, C. (Ed.). Aristotle: Nicomachean Ethics, Book VII - Symposium Aristotelicum. Oxford: Oxford University Press, 2005. p. 209-235.

REES, D. A. Aristotle's treatment of phantasia. In: ANTON, J.; KUSTAS, G. (Ed.). Essays in Ancient Greek Philosophy. Albany: State University of New York Press, 1971. p. 491-504.

RICHARDSON, H. Desire and the Good in De Anima. In: NUSSBAUM, M.; RORTY, A. Essays on Aristotle's De Anima. Oxford: Oxford University Press, 1992. p. 381-399. 
RICHARDSON, R. Brentano on Intentional Inexistence and the Distinction between Mental and Physical Phenomena. Archiv für Geschichte der Philosophie, Berlin, n. 65, p. 250-82, 1983.

RIEL, G.V. Pleasure and Good Life: Plato, Aristotle and the Neoplatonists. Leiden: Brill, 2000.

RODRIGUES, N.; CASTRO, R. O óbvio ululante: primeiras confissões: crônicas. São Paulo: Companhia das Letras, 1993.

RORTY, A. O. Akrasia and Pleasure: Nicomachean Ethics Book 7. In: RORTY, A. O. Essays on Aristotle's Ethics. California: University of California Press, 1980a.

RORTY, A. O. Essays on Aristotle's Ethics. California: University of California Press, 1980b.

RORTY, A. O. The Place of Pleasure in Aristotle's Ethics. Mind, Oxford, v. 83, n. 332, p. 481497, 1974.

ROSS, D. Aristotle. London and New York: Routledge, 1923.

ROSS, D. Aristotle's Metaphysics: edited with introduction and commentary. Oxford: Clarendon Press, 1924. v. 1.

ROSS, D. De Anima: edited with introduction and commentary. Oxford: Clarenton Press, 1961.

ROSS, W. D. (Org.). The Great Books. Oxford: University Press, 1980.

ROSS, D. Parva Naturalia: a revised textwith introduction and commentary. Oxford: Clarenton Press, 1955.

SCHIELDS, C. Intentionality and Isomorphism in Aristotle. In: WIANS, W.Proceedings of the Boston Area Colloquium in Ancient Philosophy: volume XI 1995. London : University Press of Americ, 1997, p. 371-374.

SCHOFIELD, M. Aristotle on the Imagination. In: BARNES, J.; SCHOFIELD, M.; SORABJI, R. Articles on Aristotle: Psychology and Aesthetics. London: Duckworth, 1979. v. 4

SEDLEY, D. Oxford Studies in Ancient Philosophy. Oxford: Oxford University Press, 2007. v. 32. SHERMAN, N. The Fabric of Character. Oxford: Clarendon Press, 1989.

SKEMP, J. B. Orexis in De Anima III 10. In: LLOYD, G. E. R.; OWEN, G. E. L. Aristotle on mind and the senses. Cambridge: Cambridge University Press, 2007.

SMITH, A. D. Character and Intellect in Aristotle's Ethics. Phronêsis, Netherlands, v. 41, n. 1, p. 56-74, 1996.

SORABJI, R. Aristotle on the Role of Intellect in Virtue. Em: RORTY, A. O. Essays on Aristotle's Ethics. California: University of California Press, 1980.

SORABJI, R. From Aristotle to Brentano: the development of the concept of intentionality. In: ANNAS, J. Oxford studies in Ancient Philosophy: Supplementary volume 1991: Aristotle and the later tradition. Oxford: Clarenton Press, 1991. 
SORABJI, R. Intentionality and Physiological Processes: Aristotle's Theory of Sense Perception. In: NUSSBAUM, M.; RORTY, A. Essays on Aristotle's De Anima. Oxford: Oxford University Press, 1992.

SPEIGHT, A. Listening to reason: the role of persuasion in Aristotle's account of Praise, Blame, and the Voluntary. Philosophy \& Rhetoric, University Park, v. 38, n. 3, p. 213-225, 2005.

STEWART, J. A. Notes on the Nicomachean Ethics of Aristotle. Oxford: Clarenton Press, 1892.

THAMER, E. Tradução de "Problema XXX” de Aristóteles. Disponível em: <https://pt.scribd. com/document/263900813/Traducao-de-Problema-Xxx-de-Aristoteles>. Acesso em: 21 jul. 2016 .

URMSON, J. O. Aristotle’s Ethics. Oxford: Blackwell, 1988.

VIANO, C.; DHERBEY, R. Corps et Ame. Paris: Librairie Philosophique, 1996.

WEDIN, M. V. Mind and Imagination in Aristotle. New Haven: Yale University Press, 1988.

ZINGANO, M. Aristotle and the problem of method in Ethics. In: SEDLEY, D. Oxford Studies in Ancient Philosophy. Oxford: Oxford University Press, 2007a. v. 32, p. 297-330.

ZINGANO, M. Aristóteles: Ethica nicomachea I 13 - III 8: tratado da virtude moral. Tradução de Marco Zingano. São Paulo: Odysseus, 2008.

ZINGANO, M. Estudos de Ética Antiga. Porto Alegre: Discurso Editorial, 2007b. (Coleção Philosofia).

ZINGANO, M. Razão e sensação em Aristóteles: um ensaio sobre De anima III 4-5. Porto Alegre: LP\&M, 1998.

ZINGANO, M. (Org.). Sobre a Ética Nicomaqueia de Aristóteles. São Paulo: Odysseus, 2010. 
ste livro foi produzido em formato 180 x $240 \mathrm{~mm}$ e utiliza as tipografias
DTL Haarlemmer e Anglecia Pro, com miolo impresso na Edufba, em papel Alta Alvura $75 \mathrm{~g} / \mathrm{m}^{2}$ e capa em Cartão Supremo $300 \mathrm{~g} / \mathrm{m}^{2}$, impressa na I. Bigraf.

Tiragem: 400 exemplares 